\section{DÜBLIN}

Books

AFIS (Association of Franco-Irish Studies)

Publications

\title{
Patrimoine/Cultural Heritage in France and Ireland
}

\author{
Eamon Maher \\ Technological University Dublin, eamon.maher@tudublin.ie \\ Eugene O'Brien
}

Follow this and additional works at: https://arrow.tudublin.ie/afisbo

Part of the Arts and Humanities Commons

\section{Recommended Citation https://arrow.tudublin.ie/afisbo/2 \\ This Book is brought to you for free and open access by the AFIS (Association of Franco-Irish Studies) Publications at ARROW@TU Dublin. It has been accepted for inclusion in Books by an authorized administrator of ARROW@TU Dublin. For more information, please contact arrow.admin@tudublin.ie, aisling.coyne@tudublin.ie,gerard.connolly@tudublin.ie.}

Maher, Eamon and O'Brien, Eugene, "Patrimoine/Cultural Heritage in France and Ireland" (2019). Books. 2.

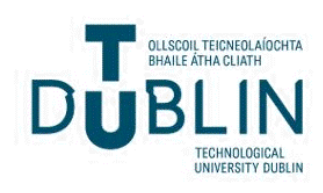




\section{Patrimoine/Cultural Heritage in France and Ireland}




\section{STUDIES IN FRANCO-IRISH RELATIONS}

VOLUME 14

SERIES EDITOR

Dr Eamon Maher,

Technological University Dublin - Tallaght Campus

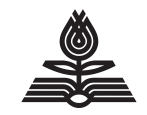

PETER LANG

Oxford · Bern · Berlin · Bruxelles · New York · Wien 


\section{Patrimoine/Cultural Heritage in France and Ireland}

Eamon Maher and Eugene O'Brien (eds)

PETER LANG

Oxford · Bern · Berlin · Bruxelles · New York · Wien 
Bibliographic information published by Die Deutsche Nationalbibliothek Die Deutsche Nationalbibliothek lists this publication in the Deutsche Nationalbibliografie; detailed bibliographic data is available on the Internet at http://dnb.d-nb.de.

A catalogue record for this book is available from the British Library.

A CIP catalog record for this book has been applied for at the Library of Congress.

Cover image: Faded Glory (shop front now demolished), Strokestown, Co Roscommon. (c) Paul Butler, a photographer based in County Leitrim. For further information: www.paulbutler.me.

Cover design: Peter Lang

ISSN 1864-273X

ISBN 978-1-78874-660-1 (print) • ISBN 978-1-78874-661-8 (ePDF)

ISBN 978-1-78874-662-5 (ePub) • ISBN 978-1-78874-663-2 (mobi)

(C) Peter Lang AG 2019

Published by Peter Lang Ltd, International Academic Publishers, 52 St Giles, Oxford, OX1 3LU, United Kingdom

oxford@peterlang.com, www.peterlang.com

Eamon Maher and Eugene O'Brien have asserted their right under the Copyright, Designs and Patents Act, 1988, to be identified as Editors of this Work.

All rights reserved.

All parts of this publication are protected by copyright.

Any utilisation outside the strict limits of the copyright law, without the permission of the publisher, is forbidden and liable to prosecution.

This applies in particular to reproductions, translations, microfilming, and storage and processing in electronic retrieval systems.

This publication has been peer reviewed.

Printed in Germany 
To our families, whose support and understanding of the work we do make it both possible and enjoyable. 



\section{Contents}

List of Figures $\quad$ xi

Avant-propos/Preface xiii

Acknowledgements $\quad$ xv

EAMON MAHER AND EUGENE O'BRIEN

Introduction: Patrimoine/Cultural Heritage in France and Ireland I

PART I Coming to Terms with Patrimoine II

EUGENE O'BRIEN

I Metanoia and Reflexive Thinking: Towards a Deconstruction of Patrimoine/Cultural Heritage

EÓIN FLANNERY

2 Debt as Inheritance

HARRY WHITE

3 'We did not choose this patrimony': Irish Musical

Inheritances since Independence

PART II Tourism and Culture

TONY KIELY

4 'Protestant Strangers and Others': Re-imagining the

Contribution of French Huguenots and their

Descendants to Ireland's Ancient 'Patrimoine' 
viii

CATHERINE MAIGNANT

5 The Reification of Sceilg Mhichíl

103

DÉBORAH VANDEWOUDE

6 Faith-based Tourism in Ireland and France

I 2 I

PART III Linking Products to Patrimoine

I 4 I

PATRICIA MEDCALF

7 Irish Cultural Heritage through the Prism of Guinness's Ads in the 1980 os

BRIAN MURPHY

8 A Traditional Irish Family Butcher Shop:

'Harnessing the power of Patrimoine'

JULIEN GUILLAUMOND

9 'Butter them up': When Marketing Meets Heritage The Case of Irish Butter in Germany

PART IV Literature and Patrimoine 203

MAGUY PERNOT-DESCHAMPS

Io 'Enfants d'ici, parents d'ailleurs'

205

MARY PIERSE

II George Moore: A Case of Dúchas/Patrimoine in Flux?

GRACE NEVILLE

I2 'I don't think I could have made a decent living without the French': An Analysis of Reviews of Irish Literature in Le Monde, 1950-2017 
Notes on Contributors

Index 263 



\section{Figures}

Figure 7.I. No beer comes near (Matt Doyle) $\quad 152$

Figure 7.2. No beer comes near (Ray Houghton) 153

Figure 8.I. Brian Murphy, Lucy Murphy and Michael Murphy on the final day of M. J. Murphy's Butcher Shop $\quad 163$

$\begin{array}{ll}\text { Figure 8.2. The Fourth Space Model } & 167\end{array}$

Figure 8.3. Key strands of the Fourth Space Model $\quad{ }_{168}$

Figure 9.I: Butter production in selected EU countries

$(\mathrm{I}, 000 \mathrm{t})$ in $2015 \quad 190$

Figure 9.2. Detail of Kerrygold logo 196

Figure 9.3. Detail of Kerrygold website first page $\quad 197$

Figure 9.4. Details of Kerrygold myths 197

Figure 9.5. The grass is greener on the other side welcome to Ireland 



\section{Avant-propos/Preface}

I am delighted and honoured to preface this significant essay collection on how patrimoine, that elusive and multifaceted concept, applies to France and Ireland. It is true, as is stated in the editors' engaging Introduction, that the term has a myriad of meanings in French, so much so that one could almost argue that it is untranslatable. The English version that is used by the editors, 'cultural heritage', does come close to capturing what patrimoine encompasses, and the various essays similarly treat of its many manifestations in French and Irish society.

Hence we come across discussion of subjects as diverse as: debt inheritance; the support by French publishers and Le Monde newspaper of Irish writers in French translation; religious tourism in France and Ireland; the UNESCO heritage site of Skellig Michael, the Atlantic island off the south-west coast of Ireland that was home to a monastic settlement many centuries ago; the traditional Irish butcher's shop as an example of patrimoine; the impact of French Huguenot settlers on the built environment, the banking system and other aspects of Dublin's heritage; Irish musical inheritances, and so on. This overview is a tour deforce, another remarkable accomplishment in the long list of books brought out under the auspices of the National Centre for Franco-Irish Studies, located in Tallaght, and its ancillary organization, the Association of Franco-Irish Studies (AFIS).

Essay collections around a specific theme like this one generate real insights and supply an outlet for original scholarship. The AFIS has been exemplary in bringing together scholars from France and Ireland to debate issues and discover, in many instances, a shared patrimoine, common beliefs, but above all a deep-rooted friendship that is the fruit of centuries of exchange and cross-fertilization between our two countries. 
Mes félicitations s'adressent aux éditeurs de cet ouvrage, Eamon Maher et Eugene O'Brien, ainsi qu'à tous les contributeurs, pour le travail qu'ils ont investi dans ce projet. Le résultat est à la hauteur de nos attentes, un recueil riche et passionnant. 


\section{Acknowledgements}

The editors are most appreciative of the support of the French Embassy in Ireland; the Department of English Language and Literature; the Mary Immaculate College Institute for Irish Studies, and the other sponsors, who facilitated the running of the conference from which this collection emerged. 



\section{Introduction: Patrimoine/Cultural Heritage in France and Ireland}

Assessing something as all-pervasive as cultural heritage can run the risk of resorting to clichés and stereotypes, even though these very things are also an integral part of what constitutes the patrimoine of any given society. The French are rightly acclaimed for their fashion, wines, gastronomy, literature, philosophy, regional specificities, architecture, and café culture, to name but a few of the Hexagone's most distinctive traits. Ireland, on the other hand, has its pubs, its writers, many of whom traditionally spent far too much time in the aforementioned pubs, its fighting spirit, its greenness, its historic struggle with its nearest neighbour, perfidious Albion, its beef and its Guinness. Patrimoine is what marks one country out from any other country; it is what makes it distinctive, different, sometimes appealing, at other times, unappealing. Therefore, when the organizers were considering the theme for the AFIS 2017 conference in Limerick, the former Conseiller Culturel at the French Embassy, Frédéric Rauser, suggested it could be both interesting and worthwhile to examine how cultural heritage plays out in both countries. The view beforehand was that the French are more adept at underlining their heritage, even at commodifying it, than the Irish are, but some of the essays you will read in this collection illustrate the fact that the Irish are starting to catch up in this regard, as the country begins to attract more and more tourists to its shores and to see the potential that has for economic prosperity.

There are several reasons why Irish writers and artists were attracted to France, but patrimoine was certainly a significant factor in their migration. After the Revolution, France overthrew the monarchy to become a Republic, which distinguished it in Irish eyes from England. Then there was the indisputable Catholic heritage that was shared by the two countries, 
although practised in very different ways, a heritage that shaped them in ways of which they were sometimes unaware. Irish seminarians went to France to study for the priesthood during the Penal Laws; the French were Ireland's closest ally in its centuries-old struggle against England and, more recently, in their support of Irish agriculture within the European Union, a goal that was closely aligned to France's own national interests. (With Brexit looming on the horizon, the entente cordiale between the Celtic cousins will assume an even greater importance). Strangely enough, with all the movement of Irish people to France, the language barrier does not seem to have caused as much difficulty as one might expect, because Irish exiles in general appear to have become adept at the language quite quickly. A good example of this is the writer George Moore (I852-I933), who arrived in Paris as a young man with little or no knowledge of the French language and went on to become one of the best known figures in Parisian artistic circles during the I870s. In Confessions of a Young Man, he describes his excitement at the prospect of living in Paris, where he hoped to become a famous painter - he would subsequently discover that he did not possess the requisite talent to succeed as an artist and took up writing instead. Before embarking on the boat that would bring him to his chosen destination, Moore remarked:

France! The word rang in my ears and gleamed in my eyes. All my senses sprang from sleep like a crow when the man on the look-out cries, 'Land ahead!' Instantly I knew I should, that I must, go to France, that I would live there, that I would become as a Frenchman. ${ }^{1}$

Moore's enthusiasm for France was predicated on the fact that he knew it to be a country which cherished artists and valued learning. His experience of Ireland was very different: he found the insular attitudes and superstitious religiosity of his home country inamicable at best to his artistic sensibility. He believed that he could be happy and comfortable in the type of setting that Paris would provide, a belief that proved well founded, as Moore

I George Moore, Confessions of a Young Man (Glamorgan, South Wales: Leaf Classics, 2013), no page numbers supplied. 
became an integral part of the influential group of writers and artists who congregated in the Café Athènes, a place he describes with much fondness in Confessions of a Young Man. His biographer Adrian Frazier quotes the artist Manet saying to Moore on one occasion: 'There is no Frenchman living in London who occupies the same position as you do in Paris', a definite compliment to the son of a landlord and parliamentarian from the West of Ireland. ${ }^{2}$ Moore definitely made an impression during his period in Paris and he mined the experiences he had in the French capital to fuel his creative imagination.

Moore learned from French writers such as Balzac and Zola the importance of place in good fiction. Place and patrimoine are closely linked and many renowned French and Irish writers are known for their ability to capture the essential details of the settings in which they locate their fictions: one need only think of Mauriac's reproduction of the Landes district around Bordeaux, Joyce's Dublin, Heaney's Bellaghy, Flaubert's Normandy, Zola's Paris, Balzac's representations of Paris and provincial France, McGahern's Leitrim/Roscommon, Yeats' Sligo. Heaney once remarked that associations with place are created through language and ideology:

Instead of just identifying with one place, and telling the story of a people in that place, poetry is also able to create, through language and imagery, another place "where the mind could take shelter from the actual conditions..

Taking shelter 'from the actual conditions', as Heaney puts it, is something that many artists seek to achieve in their work. Place is an essential trigger in this process, as it has within it the power to resuscitate images and memories that can open out onto some higher artistic plane. The 'other' place that is reached through art is infused with the personal memories of the writers, and thus, over time, often assumes a mythical status. In this way, art fulfils some of the same functions as 'terroir', by encapsulating the

2 Cited by Adrian Frazier, George Moore 1852-1933 (New Haven, CT and London: Yale University Press, 2000), 6I.

3 Cited in Eugene O'Brien, Seamus Heaney as Aesthetic Thinker: A Study of the Prose (New York: Syracuse University Press, 2016), I89. O’Brien devotes a full chapter to Heaney's sense of place in this study. 
soil, flora and fauna, people and stories that permeate a particular 'place' and, in so doing, give it a universal resonance.

This is all closely linked also to the evolution of patrimoine. A pertinent example is how readers of John McGahern's (1934-2006) fiction cannot avoid noticing strong similarities between the figures and landscapes it evokes and the people and places the writer knew in real life. He was acutely aware of how important it was to write from personal knowledge, and from everyday experience, in order to convey the beauty that can be found in the rituals of ordinary people going about their daily business in small rural communities. In creating his memorable array of characters, McGahern borrowed certain traits from local figures whom he met regularly in Ballinamore or Mohill or in pubs and marts around Leitrim. He also drew inspiration from the landscape he observed around him for several decades in the north-west midlands of Ireland. When one reads his work, one has the impression of hearing the sound of a real hammer on a real anvil: it rings true on every note it delivers.

Eamonn Wall, in Writing the Irish West: Ecologies and Traditions (2011), remarks that we have become accustomed to thinking of John McGahern 'as a writer of rural Ireland - of farms, country kitchens, harvest rituals, visits to Boyle for shopping and excursions to Strandhill for holidays. ${ }^{4}$ The reality, according to Wall, is far more complex than this. In order to create good art, McGahern was aware of the need to distance himself from his material in order to maintain objectivity. Memoir opens with the following lines:

The soil in Leitrim is poor, in places no more than an inch deep. Underneath is daub, a blue-grey modelling clay or channel, a compacted gravel. Neither can absorb the heavy rainfall. Rich crops of rushes and wiry grasses keep the thin clay from being washed away. ${ }^{5}$

This description of the soil is deliberately designed to anchor the narrative in a particular place. It serves to distinguish Leitrim from other parts of Ireland, to show what is unique about its landscape. It is an untamed, viscous University of Notre Dame Press, 2011), 89.

5 John McGahern, Memoir (London: Faber \& Faber, 2005), I. 
type of topography that makes farming a hazardous exercise. McGahern was intent on delineating for his readers the scenes he observed for the majority of his life and that he transposed into his fictional and prose writing. He wanted to capture the environment that inspired his literary vocation, the people who lived there, the rituals and customs they practised. These are all constituent parts of the cultural heritage of 'McGahern country'.

In this regard, the Irish experience is very different from the history of France, with its long history of colonialism. In an interesting recent study, Oana Panaïté notes the growing popularity of postcolonial studies in contemporary fiction in French, which she feels may have something to do with the vibrancy that is currently palpable in this area and the new perspectives it offers on French identity. Panaïté quotes Alice L. Conklin who observes that the French colonial project, 'rested upon certain fundamental assumptions about the superiority of French culture and the perfectibility of humankind. It implied that France's colonial subjects were too primitive to rule themselves but were capable of being uplifted'. She continues: 'It intimated that the French were particularly suited, by temperament and by virtue of both their revolutionary past and their current industrial strength, to carry out this task. ${ }^{6}$ How close such sentiments seem to those which dominated England's attitude to Ireland, with the emphasis that is placed on the 'superiority' of the colonizer and what they considered the civilizing aspect of their mission, the alleged desire to lift the indigenous population out of their ignorance and show them the benefits of doing things the British way.

Panaité also cites Fanon's classic text The Wretched of the Earth (196I) to underline how differently the colonizer and the colonized view the land: 'For the colonized people the most essential value, because the most concrete, is first and foremost the land: the land which will bring them bread and, above all, dignity.7 This may explain the visceral attachment the Irish have always shown to the land, an attachment that one sees in John B. Keane's The Field and in much twentieth-century Irish fiction. (Liverpool: Liverpool University Press, 2017), 55-6. 
Without the land, there can be no security and there is always the threat that someone, sometime, will take the property off those who have diligently worked it. Such a fear is not always confined to the colonizer either, as Camus' accounts of the Pieds-Noirs (French colonists) in Algeria will attest. For them, the experience of abandonment by the French metropole and the antipathy of the local population led to the inevitable loss of the land and the lifestyle they had cultivated, often by dint of hard work and personal hardship.

In considering patrimoine as it is presented in this collection, therefore, it is important to be cognizant of how different the concept is in a huge country like France, whose significant presence in Africa, Canada, Asia, the United States, the Pacific and other colonial outposts has led to the development of an international multicultural identity which can at times be unstable and volatile, as the terrorist attacks in France have shown in recent times. While Irish culture has undoubtedly been changed by the spectacular economic growth of the Celtic Tiger and the subsequent crash, by the concomitant decline of the influence of the Catholic Church, by the influx of a large number of immigrants, it could not claim to resemble France in too many ways. Our diaspora, while extensive, could never rival French implantation and inculturation in various parts of the world. French patrimoine is made up of many cultures and many parts; the vast Francophonie movement has deep tentacles in virtually every continent.

The essays you will read show the rich diversity of cultural heritage that one encounters in both countries. The opening part, entitled 'Coming to Terms with Patrimoine', begins with Eugene O’Brien's deconstruction of the chosen theme of the book. He takes the terms 'Heritage, inheritance, patrimony, dúchas' as cognates that are used to describe the largely unwritten but strongly ideologically felt notions that we have of our socio-historical cultural community. The chapter probes how, in this the decade of commemorations, the modalities of these notions are passed on, and how we as citizens of Ireland are interpellated as people who share an Irish patrimony or sense of cultural heritage. Using Pierre Bourdieu's notions of the doxa, where 'a state of immediate adherence that is established in practice between a habitus and the field to which it is attuned', and developing these to show how a doxa can become part of our unconscious view of the world, this 
chapter traces how aspects of Irish heritage became doxological. It goes on to examine aspects of Irish patrimony and explore how the doxological and uncritical reading of this has led to current societal and cultural problems like the credit crash, the bank bailout and the many scandals involving the systemic abuse of children by Church-related organizations. The systemic responses to these issues will be traced to a monological reading of heritage, and a different perspective will be traced therefrom.

Eóin Flannery's chapter provides a nuanced analysis of how notions of debt form part, in the words of Margaret Atwood, 'of the elaborate imaginative construct that is human society'. In Flannery's view, there is a close link between cultural inheritance and indebtedness. Focusing initially on the heritage industry, this chapter illustrates how art can at times be subjected to economic imperatives that really should not form part of its remit. Flannery takes issue with the readings of certain academics who saw some positive aspects to the recent prominence of Irish literature, music and dance on the world stage, because of the prestige and financial gain it brought the artists. The link between cultural vibrancy and economic wealth does not stand up to scrutiny in Flannery's estimation, art being, of necessity, countercultural, and he sets about proving his thesis by a discussion of a number of contemporary literary, economic and cultural texts.

In the final essay of Part I, Harry White explores Irish musical inheritances since Independence. Part of White's title, 'We did not choose this patrimony', is taken from a poem by Aidan Mathews from his 1977 collection, Windfalls. White considers it an apposite summary of the evolution of both the literary and musical traditions in Ireland since Independence. Drawing excellent parallels between the Irish musical and literary traditions, a task for which his position as a renowned poet and musicologist provides him with unique insights, White concludes by referring to the contrast between Ireland's assiduous cultivation of European literary genres and her disavowal of Europe's musical genres, which 'throws the question of musical patrimony into sharp relief'.

The second part, 'Tourism and Culture', contains an essay by Tony Kiely on the influence of the French Huguenots on Ireland's banking, built environment, commerce and culture. Kiely concludes that Ireland would seem to have adopted 'a blinkered or conditional approach to celebrating 
our Huguenot inflected heritage', a fact that risks missing out on the potential that this heritage contains from a cultural and even tourism perspective. Catherine Maignant's chapter deals with the reification of Sceilg Mhicíl, off the coast of Kerry, one of the rare Irish inclusions on the list of the UNESCO World Heritage Sites. Maignant questions whether ancient sites should be protected by making them into museums or places that are not open to visitors, or if they should be reinvigorated by allowing access to them through technology or other means, which could possibly lead to reification. Comparing Skellig Michael Island to Mont St Michel leads Maignant to conclude that the Irish site is 'emblematic of the human mind's complexities and power', and hence, an integral part of Gaelic heritage.

Déborah Vandewoude's contribution looks at faith-based tourism in France and Ireland. Religion is recognized as having been the driving force of the earliest tourism, with holy sites like Rome and Jerusalem being the main destinations. Irish people were, and still are, very devoted to Lourdes, and Vandewoude argues that this should make them more aware of the possibilities of attracting larger numbers of tourists to what she describes as 'an underdeveloped market', by learning from French marketing techniques and the development of proper infrastructure.

Part III contains chapters dealing with the iconic brand Guinness, the attractions of the traditional family butcher shop, and the phenomenal success of the Kerrygold brand in Germany. Each of the three products mentioned owes much of its success to how it is linked to Ireland's cultural heritage. Patricia Medcalf shows how Guinness advertising during the 1980 s, a depressing decade in Irish history, with record emigration and mounting unemployment, chose to emphasize the positives, with campaigns that linked its product to success and pleasure by using sporting figures, singers, Concorde, the fastest airplane of its time, in order to help people to rise out of the gloom that was enveloping the country. Because of its close associations with Irishness, there is a sense in which the brand was using the known resilience of Irish people, their ability to pull themselves out of the mire, to promote its product. Brian Murphy uses the example of his own family's traditional butcher shop to show how such a model, in an age of globalization, might well enjoy renewed success. He argues that the 'authentic' family butcher shop in Ireland 'can exploit its cultural 
heritage as a traditional gastronomic entity to capitalize on its associated sense of patrimoine. Finally, Julien Guillaumond remarks on the strong presence of Kerrygold butter in German supermarkets. The brand has attained 'iconic' status in Germany, with weekly sales of 3 million packs in 2016. Guillaumond muses on why Irish butter, which does not really exemplify Irish culture, assumes the badge of Irish identity through Kerrygold for many Germans. He concludes that Kerrygold have managed to shape conceptions of Ireland by 'presenting a country's identity in a manner that conforms to the image people have abroad of their country'. It is significant that, while only a small number of German people visit Ireland, those who have done so and plan to do so, have an image of the country that has been mediated to them through the ads they have seen for Kerrygold.

The final part deals with literature and patrimoine. Maguy PernotDeschamps highlights the experience of emigration as recounted in literary texts by Irish people in England and Algerians in France. In a time of severe economic depression in both countries, the natural destination for young (mainly male) Algerians and Irish was the nearby colonial power to which their countries had been subjected for some time. Using writers like Azouz Begag and Ahmed Kalouaz, alongside Brian Kearney and John Lydon, Pernot-Deschamps concludes that the second generation of emigrants retain little or nothing of the language and religion of their fathers, while the original emigrants find themselves outsiders in their country of birth and their place of work; they are people who no longer have a home.

Mary Pierse uses the example of George Moore to show patrimoine in flux. Taking some core texts such as the short story collection The Untilled Field and the novella The Lake, Pearse shows how Moore interprets culture as enriched by contact and interaction across genres and on a wide geographical scale. For this Irish writer, who was strongly immersed in France and all things French, patrimoine was, and indeed should be, multifaceted. The collection closes with an analysis of the positive reception of Irish writers in French translation in Paris. Indeed, without the success they enjoyed in France, a host of Irish writers, some well known, and others far less so, could not have survived. Grace Neville shows how certain French publishing houses demonstrated a predilection for Irish writers, who also found favour in the review pages of Le Monde. The French publisher, 
Sabine Wespieser, known especially for having brought Nuala O'Faolain to international prominence, is singled out for particular mention by Neville, who also remarks on 'Le Monde's almost blanket praise for Irish literature', which she sees as being 'the key age-old component of Ireland's patrimoine'.

As can be seen from this overview, patrimoine is an elusive concept, but one that is germane to many of the elements that go into ensuring the cultural specificity of France and Ireland. In his 2002 study, Landscape and Power, William Mitchell writes:

Landscape is a natural scene mediated by culture. It is both a represented and presented space, both a signifier and a signified, both a frame and what a frame contains, both a real place and its simulacrum, both a package and the commodity inside the package. $^{8}$

This is a formula that applies very well to patrimoine, to the way in which it forms part of culture and is a means of mediating that culture, how it acts both as signifier and signified, a frame and what is enclosed within the frame. You will discover in the pages that follow distinctive ways in which the theme pervades the cultural life of both Ireland and France.

8 William Mitchell (ed.), Landscape and Power (Chicago: University of Chicago Press), 5 . 
PART I

Coming to Terms with Patrimoine 



\section{Metanoia and Reflexive Thinking: Towards a Deconstruction of Patrimoine/Cultural Heritage}

Heritage, inheritance, patrimony, duchas - all of these are terms that are used to describe the largely unwritten but strongly ideologically felt notions that we have of our socio-historical cultural community. In this, the decade of commemorations, the modalities of how these notions are passed on and how we, as citizens of Ireland, are interpellated as people who share an Irish patrimony or sense of cultural heritage. This chapter will offer a theoretical examination of how such notions are created, and will then suggest that perhaps the best method of commemorating the past is to break with the past, in order to set out new parameters for the future.

Initially, the question must be posed as to what is the epistemological status of patrimony. The Oxford English Dictionary gives the following meaning - an estate or property belonging by ancient rite to an institution or corporation. It suggests that the term is especially suited to use in an ecclesiastical context: 'the ancient estate or endowment of a church or religious body', and makes the point that this is especially true of territory held by the Pope. In a broader sense, the following meanings are offered:

Property inherited from one's father or passed down from one's ancestors; an inheritance.

Something abstract which is inherited or handed down, and which is deemed to be valuable. ${ }^{1}$

The etymology is Anglo-Norman 'patremoine', through Middle-French 'patrimonie', from classical Latin 'patrimonium', which is the classical Latin 
property of the head of a household, personal estate, fortune, private chest of the Roman emperors, in post-classical Latin also estate of the Church. ${ }^{2}$

Generally, patrimony or the cognate Irish term, dúchas, is an intangible term, which suggests aspects of cultural and ideological identity and heritage that we can feel, and intuit, but not express in any rational manner. Such patrimony can be seen as a belief, something that we feel and to which we acquiesce, but which has difficulty in being rationally explained. In the current climate, we see that a British sense of patrimony is being enunciated through the Brexit process, where an inherited or felt sense of independence, of standing alone, of being connected to Europe but of never being quite in Europe, is at the core of current political debate. One is reminded of the apocryphal headline in The Times: 'Fog in channel - Continent cut off'. One could see this as a natural patrimony or cultural inheritance of the British as a nation. Similarly, in Ireland, we have a strong sense of ourselves as an independent nation, which is underwritten by a residual sense of antiBritishness, and the decade of commemorations (1912-23) would seem to foreground that, and as a result to make our own Irish patrimony all the stronger. Clearly political, social, cultural, historical and ideological issues all play their part in the construction of a patrimony or cultural heritage, and this chapter will discuss the modality of patrimony. I want to probe its epistemological status, and to see how patrimony, patrimoine or dúchas is created and maintained in cultures. To do this, I will look at the thinking of some French writers, specifically Pierre Bourdieu and Jacques Derrida.

In terms of exploring how patrimony is created, a number of questions need to be addressed, such as: Who creates it, How it is transmitted, What type of thinking is involved, How are emotional charges created to ensure that people have a sense of allegiance and belonging to their own cultural heritage? The work of Pierre Bourdieu is of use here, as he has analysed the complex manner in which societal knowledge, both hard knowledge and attitudinal knowledge, is created and transmitted. He terms the shared beliefs that bind people together culturally and socially as 'doxa.' This term refers to the unexamined, accepted and 'taken for granted' assumptions 
and practical beliefs that people share about their own society. It is 'a set of fundamental beliefs which does not even need to be asserted in the form of an explicit, self-conscious dogma. ${ }^{3}$ It is the kind of knowledge that we all know, but which is very difficult to articulate; it is usually shrouded in implication, and shared assumption, without any need for definitions or rationalization. As Bourdieu puts it, in Outline of a Theory of Practice, the self-evidence of the common-sense world is often non-verbal: 'what is essential goes without saying because it comes without saying: the tradition is silent, not least about itself as a tradition.' ${ }^{4}$

For Bourdieu, notions of the doxa equate with what might be termed practical belief:

Practical belief is not a 'state of mind', still less a kind of arbitrary adherence to a set of instituted dogmas and doctrines ('beliefs'), but rather a state of the body. Doxa is the relationship of immediate adherence that is established in practice between a habitus and the field to which it is attuned, the pre-verbal taking-for-granted of the world that flows from practical sense. ${ }^{5}$

One could suggest that this sense of identity or habitus as something that is taken for granted; it can be facilitated and developed by notions of patrimony. Important terms here are 'field' and 'habitus', and I think a sense of these terms, and of their interaction, may offer us a better opportunity to understand how notions of cultural inheritance are passed on. In this regard, it is interesting to note that in the dictionary definitions cited earlier, the passive voice was used. It is as if cultural inheritance is something that just transpires, without any active agency of its own. Such a passive reception of received ideas has significant dangers for issues of freedom and equality in our culture, and an analysis of Bourdieu's ideas may help us to understand why this is actually untrue, and why acts of reflective thinking, or metanoia,

Pierre Bourdieu, Pascalian Meditations, trans. Richard Nice (Stanford, CA: Stanford University Press, 2000), 16. Pierre Bourdieu, Outline of a Theory of Practice, trans. Richard Nice (Cambridge: Cambridge University Press, 1977), 167. Italics original.

5 Pierre Bourdieu, The Logic of Practice, trans. Richard Nice (Cambridge: Polity, I990b), 68. 
are crucial if such passivity and acquiescence is to be avoided. Looking at cultural knowledge, he speaks of it as part of a cultural field. For Bourdieu,

a cultural field is defined as a series of institutions, rules, rituals, conventions, categories, designations, appointments and titles which constitute an objective hierarchy, and which produce and authorise certain discourses and activities. ${ }^{6}$

However, these do not exist together in a smooth or hierarchical organization, but rather, are formed by interactions of these different elements and by conflict between them. This is a dynamic and not a static process: 'cultural fields, that is, are made up not simply of institutions and rules, but of the interactions between institutions, rules and practices'. Therefore, he is looking at a fluid structure, wherein agents are pushed and pulled between varying values within the field. Fields are often governed by ruling principles; for example, he suggested that cultural and economic capital operated as two hierarchized poles in a social field, which: 'worked a little like a magnetic field, with positions determined by their relationship to the two poles. ${ }^{8}$ The field, then, is like the rules of the game that is 'much more fluid and complex than any game that one might ever design."

His other concept, 'habitus', speaks of the 'constraint of social conditions and conditionings, right in the very heart of the "subject"; $;{ }^{10}$ it is 'social life incorporated, and thus individuated', ${ }^{11}$ it is 'as society written into the body, into the biological individual.' ${ }^{12}$ He sees it as a way of explaining how an individual is both conditioned by society, while at the same time contributing to the changes in that society. Different fields all contribute to the nature of the habitus: thus in an academic field, the rules

6 Jen Webb, Tony Schirato and Geoff Danaher, Understanding Bourdieu (London: Sage Publications, 2002), 2 I.

7 Webb, Schirato and Danaher, Understanding Bourdieu, 22.

8 Michael Grenfell, Pierre Bourdieu: Key Concepts (Stocksfield: Acumen, 2008), 71.

9 Pierre Bourdieu and Loï J. D. Wacquant, An Invitation to Reflexive Sociology (Chicago: University of Chicago Press, 1992), 104.

IO Bourdieu, Logic of Practice, 2I.

II Bourdieu, Logic of Practice, 37.

I2 Bourdieu, Logic of Practice, 63. 
of the game include teaching, publishing, service at meetings, but at a more unconscious level, having the 'correct' attitudes, namely certain middleclass liberal values that are not written down, but would be expected of any initiate into the system. Similarly, an artistic habitus 'disposes the individual artist to certain activities and perspectives that express the culturally and historically constituted values of the artistic field. ${ }^{13}$

The habitus is a way of elucidating how an individual assimilates the rules of the game, or of the very different games we play, in the complex postmodern world which we inhabit. It is 'a structuring structure, which organises practices and the perception of practices', ${ }^{14}$ and it describes the way structures are embedded in an individual, and indeed a collective of individuals, so that they structure the individual as a person in a culture as well as internalizing external structures.

The relationship between fields and the habitus is crucial to Bourdieu's understanding of how society operates, and to my own investigations on the modality and epistemic structure of patrimony and cultural heritage. If the field is the rules of the game, then the habitus is 'the feel for the game'; it is the social game 'embodied and turned into a second nature. Nothing is simultaneously freer and more constrained than the action of the good player. ${ }^{15}$ He means free in the sense that he or she has internalized the rules, and is able to be creative within them; he means constrained in the sense that the rules have now become so internalized that there is not even a possibility that one may transgress them - a professional soccer player would not even think of picking up the ball and running with it, nor would a rugby player ever attempt to head the ball. In the first case, it is a formal rule; in the second, while there is no rule in rugby against heading the ball, the habitus of the rugby player would never countenance it. As Bourdieu puts it tellingly: 'the habitus is that unchosen principle of so many choices. ${ }^{16}$

I3 Webb, Shapiro and Danaher, Understanding Bourdieu, xii-xiii.

I4 Pierre Bourdieu, Distinction: A Social Critique of the Judgement of Taste, trans. Richard Nice (London: Routledge, 1984), 171 I.

I5 Pierre Bourdieu, In Other Words: Essays Towards a Reflexive Sociology, trans. Matthew Adamson (Stanford, CA: Stanford University Press, 1990a), 63. 
Thus, when field and habitus come together, they constitute 'a dialectic through which specific practices produce and reproduce the social world that at the same time is making them $;{ }^{\prime 17}$ when they are imbricated with each other, what is produced is a doxa, which takes us back to our initial point. Doxa relates to what is taken for granted, to 'what cannot be said for lack of an available discourse', ${ }^{18}$ and it produces a 'misrecognized unconditional allegiance to the "rules of the game" on the part of social agents with a similar habitus." Thus, our sense of cultural heritage or patrimony can be seen to be a creation of different fields, which in turn shapes our habituses, which in turn creates our doxic position. Therefore, if patrimony is a culturally accepted doxa, the key point for Bourdieu is that this is created at some stage before becoming reified, so there are opportunities to shape patrimony or our sense of dúchas: these are culturally dependent constructions, which are subject to change.

Thus, any doxic position is open to critique, and thence to alteration, and if we trace the connections between doxa, field and habitus, we can come to a fuller understanding of this, and in this chapter, the commemoration of the 1916 Easter Rising in 2016 will be taken as something of a case study. Looking at our commemorations, the reminiscences of 1916 were an example of this. We remember 1916 as a sacrificial gesture made in the name of nationhood, and it was remembered as such. Thousands of people came to Dublin and attended the commemorations, which in turn made this act central to what might be termed an Irish habitus as our cultural inheritance was strengthened by the repetitions and re-enactments.

The proclamation of the republic, which was read on the steps of the GPO on 24 April 1916, was read numerous times during 2016, and it foregrounds notions of remembrance as its own justification. ${ }^{20}$ The act of rebellion is located in the context of mythic remembrance: 'Irishmen and Irishwomen: In the name of God and of the dead generations from which

17 Michael Grenfell, Pierre Bourdieu: Key Concepts (Stocksfield: Acumen, 2008), 75.

I8 Grenfell, Pierre Bourdieu: Key Concepts, 120.

I9 Grenfell, Pierre Bourdieu: Key Concepts, I22.

20 The text of the proclaimation and significant factual and hoistorical information about the writing and drafting process, the reception of the document, and the different fonts used, cn be found on: <http://thergr6proclamation.ie/>. 
she receives her old tradition of nationhood, Ireland, through us, summons her children to her flag and strikes for her freedom. ${ }^{21}$ Three things are significant here. One is that Pearse is accrediting a single monological memorial thrust to the past - in other words, there is no account taken of any Irishmen and Irishwomen who may not have been keen on calling the children of a personified Ireland to arms. The second point of significance is that this act of memory is very much a performative one, which makes use of the literary trope of personification: Ireland is personified and words are put into the mouths of dead generations who may or may not have agreed with the point being made. Here, politics as a societal arena has been deftly transmuted into a familial discourse through literary rhetorical devices. The fact that the sentences are in the passive voice is interesting: rather than proclaiming that this act is insurrectionary and one that is motivated by political reasons, Pearse places this act in a series of other ones - in a way, the proclamation sees itself as just one more step in a series of steps.

The point here is that Pearse, in his telling of the tale, is using some interesting metaphors and is also feminizing nationhood in a way which can be seen as quasi-sexual, with a number of references to 'her children'. He speaks of how the Irish people, 'six times during the past three hundred years', have 'asserted it in arms', ${ }^{22}$ with the 'it' referring to the desire for freedom. This is a very partial perspective, as not all of the Irish people were involved in such assertion in arms, and this brings us to the third point of significance of the oration. All acts of memory, while they evoke the past and images of people and events that are no longer here, take place in the present, and, by definition, they are performative as opposed to constative. By using the passive voice, Pearse is very much attempting to elide the performativity and the agency of his words. As Jacques Derrida has noted, across the canon of his writing, memory is always an act, it is always something performed by a human subject in the present. It is 'the most living act of memory. ${ }^{23}$

Proclamation of the Republic.

23 Jacques Derrida, Psyche: Inventions of the Other, Volume 2 (Stanford, CA: Stanford University Press, 2007), 94. 
He goes on to talk about a discourse of mastery as 'an act of memory', which allows for engagement with the past that permits the 'formalization in an economical manner of the maximum of things to be said and thought. ${ }^{24} \mathrm{He}$ also makes the telling point that an act of memory is necessarily partial, as it consists of 'betraying a certain order of capital in order to be faithful to the other heading and to the other of the heading. ${ }^{25}$ In other words, each act of memory and the narrating of that memory is a performative act which has its own ideological and teleological imperatives, and the readers of this narration need to be aware of the 'heading' in which this narration is taking, and also to be aware that ther are 'other headings' as well.

Therefore, the Proclamation itself, that which is part of the commemoration, is a complex act of memory, which attempts to give life to the dead. In The Politics of Friendship, Derrida makes the point that an act of memory in the present is the only way in which to give some form of life to the dead:

for at stake is an act of memory - this is what must engage memory in the present, in the presence of the dead, if that can be said; for however difficult this remains to say ... the dead live and the absent are present. ${ }^{26}$

By connecting the ides of Derrida and Bourdieu, it is possible to come to a clearer understanding of the way in which the notion of commemoration is one of the steps in the creating of a doxa which sees that the acts that are being commemorated are, both de facto and de jure, worthy of being commemorated. Different elements of the field of Irish identity and history are selected, given a narrative shape, and are then gradually frozen into a doxic position, which over time and through education, narrative and culture, becomes the doxic position. Just as most of us here take patrimony and cultural heritage to be something valuable and intrinsically good, so

24 Jacques Derrida and Elisabeth Weber, Points .... Interviews, 1974-94 (Stanford, CA: Stanford University Press, 1995), I45.

25 Jacques Derrida, The Other Heading: Reflections on Today's Europe, trans. Pascale-Anne Brault and Michael B. Naas (Bloomington: Indiana University Press, 1992), 3 I.

26 Jacques Derrida, Politics of Friendship, trans. Gabriel Motzkin and Michael Syrotinski, with Thomas Keenan (London: Verso, 1997), 95. 
the idea of commemorating something is that, by definition, it must be of societal and cultural value.

This doxa has allowed various segments of the militant Republican movement - the Official IRA; the Provisional IRA; the Continuity IRA; the Real IRA - to claim warrant from the 'men of 1916'. It has also allowed many theorists and writers about 1916 to play down the violence, destruction and the fact that the Rising itself was in effect a coup d'etat by the Irish Republican Brotherhood and the Citizen Army within a much broader movement of which they were a part, the Irish Volunteers. Because the rising is seen as doxically a good thing, and because the national habitus has been conditioned, through story, history, narrative and indeed the founding acts of all of our major political parties, to see the Rising as a foundational act which gave rise to this country, then it has long been difficult to condemn violent republicanism in the twenty-six counties, and, by extension, in the six counties of Northern Ireland, as such condemnation is not part of the field.

Thus Declan Kiberd, speaks of the rising as the 'Easter Week's performance', and sees this notion of performativity as 'exactly the achievement of the 1916 rebels, who staged the Rising as street theatre and were justly celebrated in metaphors of drama by Yeats', ${ }^{27}$ and there has been much talk about the rising as a poets' rebellion, as three of the leaders, Pearse, Plunkett, and MacDonagh were poets, playwrights, and theatrical producers. In terms of patrimony, the association of poet and dramatists with violence tends to create an image that is, paradoxically, less violent and less threatening. Poets, it seems, attenuate and soften the violence, while seeing the rising as a drama tends to foreground the performative and to attenuate the blood and guts that necessarily accompany the violence. The brute facts of the matter were that of the 590 people killed during the Easter Rising, 374 were civilians, 116 were British Soldiers, twenty-three were police and seventy-seven were insurgents. There were thirty-eight children killed, all aged sixteen and under. Joe Duffy's book, which detailed the deaths of these thirty-eight children, and was something of a cause célébre during the commemoration,

27 Declan Kiberd, Inventing Ireland: Literture of the Modern Nation (London: Vintage, 1996), 203. 
seemed to cause great surprise, as 1916 had not been associated with such civilian deaths. ${ }^{28}$ On reflection, why anyone would be surprised at civilian deaths and the deaths of children in a violent insurrection that took place in a crowded capital city, without any warning, would seem curious indeed. However, after our review of Bourdieu, it should not surprise us.

The doxa of 1916, that of a poets' and playwrights' rebellion of romantic doomed young men (women were also involved, but none of those in the rising was executed - civilian women were not so lucky with some fifty being killed), is not something of which people were unaware: rather, is it an example of the self-perpetuating epistemic status of the doxa, which as a symbolic form of power, 'requires that those subjected to it do not question its legitimacy and the legitimacy of those who exert it. ${ }^{29}$ It is an example of what Derrida terms a 'politics of memory, of inheritance, and of generations. ${ }^{30}$ To attempt to break up this doxic relationship of habitus and field, as well as their capital accruals, it is necessary to adopt a reflexive and deconstructive perspective on these issues, and it is to the notion of reflexive thinking that this discussion now turns.

Reflexive thinking is not new, but it is difficult. Bourdieu suggests that by applying reflective thinking to oneself and to one's society, 'you open up the possibility of identifying true sites of freedom' going on to see this as an emancipatory process: 'social fields are universes where things continually move and are never completely predetermined. ${ }^{31}$ In Bourdieu's eyes, the business of the sociologist is to 'denaturalize and to defatalise the social world, that is, to destroy the myths that cloak the exercise of power. ${ }^{32}$ One of the core aspects of any reflexive thinking, of reflecting on what we are thinking while we are thinking, and also of breaking with a perceived

28 Joe Duffy, Children of the Rising: The Untold Story of the Young Lives Lost during Easter IgI6 (Dublin: Hachette Press, 2015).

29 Grenfell, Bourdieu: Key Concepts, I22.

30 Jacques Derrida, Specters of Marx: The State of the Debt, The Work of Mourning, and the New International, trans. Peggy Kamuf (London: Routledge, 1994), xi.

3I Pierre Bourdieu and Loï J. D. Wacquant, An Invitation to Reflexive Sociology (Chicago: University of Chicago Press, 1992), 199. Bourdieu and Wacquant, An Invitation to Reflexive Sociology, 48. 
consensus, is the notion of rupture. As Bourdieu puts it, the first stage in analysing the field and in unpacking the doxa is 'to take as one's object the social work of construction of the pre-constructed object. That is where the point of genuine rupture is situated. ${ }^{33}$

This form of reflexive thinking involves not just seeing the field as predefined and not just taking the doxa as given, but instead of looking at points of possible rupture between field and habitus and doxa in order to create a more plural and less ideologically fixated sense of patrimoine. It involves looking at the doxa and probing the elisions and attenuations within other aspects of the field that have been silenced in order to create the seemingly seamless narrative of the doxic position. This is extraordinarily difficult as it asks one to question the interaction of field, habitus and doxa that have made the person doing the enquiry who and what they are. As already noted, the interaction of these three constitutes a dialectic through which specific practices produce and reproduce the social world that at the same time is making them'. ${ }^{34}$ To ponder what are essentially part of one's origins is challenging, and can be very difficult to do for both an individual, and for a society like Ireland. However, to interrogate the patrimoine of which one is a part is necessary if that patrimoine is to be more broad and enabling and open to the future, as opposed to being trammelled and constricted by the past. Instead of having what has been termed an unconditional allegiance to the 'rules of the game', this kind of reflexive thinking questions the rules of the game as a way of making the game better and more fit for purpose. It also means that there is a realization that rules of any game are created and contextually bound, and therefore are not frozen in any form of messianic time, but rather are based in historical time, and thus are subject to change.

Hence, thinking reflexively on notions of inheritance, of the imbrication of doxa, habitus and field, involves holding up to critique structures, both conscious and unconscious, which have influenced to a significant extent, the person who is enacting the critical reflection. The process of such thinking is dialectical, aporetic, problematic and fraught with

33 Bourdieu and Wacquant, An Invitation to Reflexive Sociology, 219. Italics in original.

34 Grenfell, Bourdieu: Key Concepts, p. 75. 
difficulty, as one is moving out of the familiar and comforting realm of binary oppositions (the Easter rising was foundational to our democratic state/the Easter Rising created the Provisional IRA). These positions of supporter versus revisionist are comforting and comfortable. In discussions about the Easter Rising held during the commemoration period, it quickly became obvious that people were either very much in favour of the Rising as a foundational event, or else extremely critical of it, and both sides were happy to cite 'Easter 1916' by W. B. Yeats in support of their respective position.

Perhaps here, literature is the best way of achieving a form of reflexive thinking, as in this poem, Yeats offers both praise, blame and a slightly regretful sardonic meta-commentary on his own perspective on the euhemirization of the signatories of the treaty from seemingly occasional players in what he terms 'the casual comedy' to become mythic and foundational figures of an Ireland where:

All changed, changed utterly
A terrible beauty is born.

This refrain is generally seen as a celebration of the Rising, by associating the transcendental aesthetic category of beauty with the political and military events of the Rising itself. The central metaphor of the central section of the poem, which sees the heart enchanted to a stone, is symbolic of this.

\footnotetext{
Hearts with one purpose alone

Through summer and winter seem

Enchanted to a stone

To trouble the living stream. ${ }^{36}$
}

\begin{abstract}
A heart is at the core of every living organism, and either literally or metaphorically, its transformation into a stone cannot be seen as a positive image. In literal terms, the heart is a pump, and becoming transmuted into a stone means that it can no longer function as a pump, which signifies
\end{abstract}


immediate death in the organism within which it exists. At a metaphorical level, transforming the heart into a stone has a parallel effect, as it will be an immoveable object which will 'trouble the living stream' of life and change. A reading of these lines underlines this point, as the physical stone is soon transformed into a metaphorical one:
Too long a sacrifice
Can make a stone of the heart.
$\mathrm{O}$ when may it suffice?
That is Heaven's part, our part
To murmur name upon name,
As a mother names her child. ${ }^{37}$

The movement here is from a sense of scorn to one of grudging admiration to a final transformation into something terrible and beautiful, with Yeats as the almost reluctant chronicler of this process. I would see this poem, not as a work that avoids or evades coming to a decision on the Rising, but rather an example of what can be termed metanoia.

Writing about the political ontology of Martin Heidegger, Bourdieu speaks of 'metanoia, a change of social space which supposes a change of mental space. ${ }^{38} \mathrm{He}$ sees this as a way of thinking through the doxic givens of our vulture and habitus and instead seeing things in a new and different way. For him, reflexive thinking is grounded in the metanoetic moment. The word derives from the Greek metanoein 'to change one's mind or purpose', from meta- 'change' and noein 'to have mental perception', from noos 'mind, thought. ${ }^{39}$ For Bourdieu, the task of thought is very much this change of mind or of orientation, a new way of looking at social, cultural and political constructions by taking account of how much of the perceiver has been constructed by those self-same social, cultural and political constructions. This requires that metanoetic moment of rupture:

38 Pierre Bourdieu, The Political Ontology of Martin Heidegger, trans. Peter Collier (Stanford, CA: Stanford University Press, 1991), 36. 
The task is to produce, if not a 'new person', then at least a 'new gaze', a sociological eye. And this cannot be done without a genuine conversion, a metanoia, a mental revolution, a transformation of one's whole vision of the social world. ${ }^{40}$

We might call such vision a 'post-postmodern humanism', ${ }^{41}$ since it does not break with the 'humanist project of the Enlightenment to seek the "truth" in things'. ${ }^{42}$ As John D. Caputo notes, metanoia 'comes by way of an unexpected turn of events, by shattering our horizon of expectation', ${ }^{43}$ it is a 'passage into another order' and it makes a strong connection between the 'change of mental space' and the 'change of social space'. ${ }^{44}$ This reflexive thinking means not just accepting the common sense perception of process or events but of looking at them from a different perspective. It is difficult as we are actually critiquing part of ourselves which is very difficult to do. This kind of metanoia or rupture is at the core of reflexive thinking; it changes our worldview and by extension, it changes our world. Eisenstein and McGowan, speaking of rupture, note that it is through rupture that the major paradigm shifts in thought have occurred:

From the perspective prior to their onset, these events are impossible, and yet they transpire nonetheless. Rupture is the occurrence of the impossible, when the very ground under our feet shifts in order to transform the point from which we see. ${ }^{45}$

In his poem, I would argue that Yeats is offering just such a metanoia or a rupture, though in an extremely complex manner. He is both part of the reflexive thought and of the creation of a doxa at the same time. His sense of creating a litany of patriotic sacral figures, whose names will be

40 Bourdieu and Wacquant, An Invitation to Reflexive Sociology, $25 \mathrm{I}$.

4I Michael Grenfell and Cheryl Hardy, Art Rules: Pierre Bourdieu and the Visual Arts (Oxford: Berg, 2007), 193.

42 Grenfell and Hardy, Art Rules: Pierre Bourdieu and the Visual Arts, 194

43 John D. Caputo, What Would Jesus Deconstruct? The Good News of Postmodernism for the Church (Grand Rapids, MI: Baker Academic, 2007), 53.

44 Bourdieu, The Political Ontology of Martin Heidegger, 36.

45 Paul Eisenstein and Todd McGowan, Rupture: On the Emergence of the Political (Evanston, IL: Northwestern University Press, 2012), 4. 
'murmured', is part of the process that has resulted in a monological view of the Easter Rising, as seen in the 1966 commemorations which were openly hagiographical. At the same time, by suggesting that the motivations of such actions can be called into question, especially in his transformative metaphorical transformation of a beating heart into a stone, he is opening up a more interrogative and critical aspect of the field of the 1916 rebellion, as he is also dong by suggesting that the Rising may have been unnecessary given England's stated commitment to Home Rule after the war. This poem's complex contribution to the creation, and deconstruction, of a doxa exemplifies the complexity of which Bourdieu and Derrida so eloquently speak: sometime a metanoia and rupture can occur side by side with a creative strand of a doxa.

In terms of the commemoration of the Easter Rising, such a rupture was difficult. Given that Sinn Féin was seen as attempting to hijack the celebrations of the commemorations for its own particular doxic notions of Ireland - past, present and future - there was a concerted effort by the political establishment in Ireland to broaden the ceremonies. Hence, an Irish flag was delivered by Army personnel to every school in the country. There were celebrations in many towns and cities, and not just in Dublin. Academics and the media had a significant number of conferences, programmes, seminars and discussions all through the year, and the role of Irishmen who fought in the British Army and also the role of the RIC men involved in the Rising was also discussed, possibly for the first time in a sustained manner, since the foundation of the state. This leads towards a pluralization of response, and also to a sense that the commemoration was choosing more widely than before what exactly was to be commemorated. Of course, this process is not linear and some of the discussions were merely rehearsals of positions that were not for changing; however, different aspects of the field were certainly being enunciated and this, in itself, was a positive step.

In any act of communal remembrance, there are choices to be made, and these choices are often governed, consciously or unconsciously, by the doxa and habitus of the people making the choice. Very often, it is not a case of deliberately excluding members of the RIC and British Army, who were Irish, from the commemorations: rather is it that through the doxa 
and habitus, they just do not some into the argument at all. To refer back to Bourdieu, it goes without saying that doxically, these groups have no place in any commemoration of Easter 1916. It is as if they just are not part of the field from which the commemorative elements are to be chosen. If there is to be any form of rupture or metanoia, then such thinking needs to be interrupted and reoriented: it is impossible to allow for the ground to shift under one's intellectual position if that position is always already deeply entrenched and fortified.

To enable the 'occurrence of the impossible, when the very ground under our feet shifts in order to transform the point from which we see', there needs to be a different kind of thinking; we need to look, not at the Irish/British binary or the value-laden one of whether the Rising was a good thing for Ireland or not. We need to in some way dislodge the habitus, that 'unspoken principle of so many choices' and open up other principles of choice. We need to broaden the relational range and scope of our thinking in terms of commemoration, and to create a field of reflexive thought that will cause a redefinition of the whole notion of commemoration and what it is that we commemorate.

As an example of this, I would like to conclude with an article by Fintan O'Toole, who looks at the life of a boy born in 1916. He was not the subject of a commemoration, nor was his name read out at any of the ceremonies. His name was Peter Tyrrell:

Is it bad manners, in this week of commemoration, to think about a kid born in Ireland in 1916, a real child of the nation? I can't help thinking of one particular nobody. He was so much a nobody that when he set himself on fire on Hampstead Heath in London the year after the vainglorious 50 th anniversary commemorations of the Rising, there was nobody to claim his body. ${ }^{46}$

This is a metanoetic moment in terms of revival, as O'Toole is linking this man's self-immolation, a gesture that to those of us of a certain age will always recall the suicide by fire of a Buddhist monks in Vietnam, an image relayed by television camera across the world, and an image

46 Fintan O'Toole, 'We should not replace one form of forgetting with another', The Irish Times, 29 March 2016. 
which left a lasting impression on anyone who saw it. Thích Quảng Đức was the Vietnamese Mahayana Buddhist monk who burned himself to death at a busy Saigon road intersection on II June 1963. Quảng Đức was protesting against the persecution of Buddhists by the South Vietnamese government led by Ngô Đình Diệm. Peter Tyrrell was no such posthumous media icon; his death by fire in London in 1966 can be seen as a highly ironic counterpoint to the hagiographic commemorations of Easter 1916. Commemorations, by definition, are celebrations: they offer to public memory in the present chosen acts from the past that are deemed worthy of being remembered and celebrated. Tyrrells's suicide is something that would not have fitted into this doxa, especially in Catholic Ireland, where suicide was, and to a certain extent still is, seen as shameful and something that should not be spoken about, let alone commemorated.

O'Toole describes the life of this man, who was born in 1916 on a small farm near Ahascragh, Co. Galway. He was one of ten children and was taken into state care in January 1924, and they were sent to the 'notorious industrial school in Letterfrack'. O'Toole makes the significant point that though the school was run by the Christian Brothers, 'it is important to remember that Peter was a child of the State. It was the State that used its new independence to send him to hell:. ${ }^{47} \mathrm{O}$ 'Toole goes on to describe this man's life in Letterfrack, where beatings and abuse were the norm. In letters he sent to Senator Owen Sheehy Skeffington, in the 1950s, later edited by Diarmuid Whelan and published as Founded on Fear, Tyrrell spoke of the horrors of this place and of the abuse, paedophilia and grooming that took place:

Tyrrell joined the British army during the Second World War and was captured by the Germans. He writes: 'Life here in Stalag IIB Fallingsbostel during the last months of the war is hard and unpleasant. Yet it is heaven on Earth compared to my life' at Letterfrack. ${ }^{48}$

47 O'Toole, 'We should not replace ..., The Irish Times, 29 March 2016.

48 O’Toole, 'We should not replace ...', The Irish Times, 29 March 2016. 
Looking at how this child of the rising was treated by the Ireland that came from the rising is salutary, especially in terms of the doxa that the I9I 6 rising was a poet's and a dramatist's rebellion. The lack of ideals of this generation is another reading of the rising - a counter-doxic reading which sees the rebellion as a coup d'état within the nationalist movement, which has been retrospectively valorized by the relationships between the field of political and cultural nationalism and religion, and the habitus which the capital accruing in this field created in the citizens of the country. In July 1955, when Sheehy Skeffington (whose own father was murdered by a British army officer during Easter Week), raised the question of the vicious beating of children in schools, the minister of education, Richard Mulcahy, dismissed such concerns as a:

disgusting proceeding ... by people who are not of this country or its traditions ... people reared in an alien and completely un-Irish atmosphere'. Mulcahy, of course, had fought (very effectively) in $1916 .{ }^{49}$

In terms of cherishing all of the children of the nation equally, this would seem to be a poor response, but it is interesting how the doxa is enlisted to supress any questions or perceived faults in the overall position. The phrase 'not of this country' is a telling one, and it speaks to the dangers of a doxa that does not allow for any different form of knowledge practice to be operative in a society. In the early days of the state, and previously, in the War of Independence, a strict binarism was enforced: one was with us, or one was against us. In any war, such a binary opposition is crucial as it allows for a gathering and a bonding of the 'us' and a consequent demonization of the 'them'. One is either Irish or British, and the term 'un-Irish' is probably the worst insult that can be hurled in this type of intellectual milieu. It allows such terms to be used, not as descriptors of where one is born or where one is from, but as value judgements, where all poor behaviour can be called 'un-Irish' and by definition, in this doxic binary logic, all good behaviour is consequently Irish: all other aspects of the field are null and void. 
This is precisely where we are in terms of Kiberd calling the Rising one of dramatists and poets: as both of these professions are gentle, creative and life-enhancing, their use in the case of a bloody revolution, initiated without the permission of the Irish Volunteers themselves, which caused significant numbers of civilian dead, softens, or at least attempts to soften, the bloodiness of the deeds done. Were the Rising to be called a Rising of clerks and shopkeepers (probably more accurate in terms of the occupations of the majority of the participants), it would lack the rhetorical flavour of the more aesthetic other option.

The aestheticization of violence is something that has long been seen as dangerous, and it has been given the name of aesthetic ideology. As already noted, to a degree Yeats is participant in this process, as he avoids offering a moral and ethical judgement on the actions of the leaders of the I91 6 rebellion, and instead swerves into an almost liturgical repetition of their names, thereby enabling the process of euhemirization of which we have spoken earlier: 'To murmur name upon name, / As a mother names her child. ${ }^{50}$ This process has been termed 'aesthetic ideology' and it involves a 'phenomenalist reduction of the linguistic to the sensually empirical, a confusing of mind and world, sign and thing, cognition and percept' and by repressing the contingent relationship between 'the spheres of language and the real', and is in danger of converting the accidents of meaning to organic natural process in the characteristic manner of ideological thought.$^{51}$ As Christopher Norris has noted, such ideologies which treat language and culture as 'organic, quasi-natural products rooted in the soil of some authentic native tradition', ${ }^{52}$ are at the source of a valorizing of the self at the expense of the other - this is exactly what is happening in terms of the use of the phrases 'by people who are not of this country or its traditions ... people reared in an alien and completely un-Irish atmosphere', that we saw used by Mulcahy earlier.

5I Terry Eagleton, The Ideology of the Aesthetic (Oxford: Basil Blackwell, 1990), I0.

52 Christopher Norris, Paul de Man: Deconstruction and the Critique of Aesthetic Ideology (London: Routledge, 1988), I82. 
If the doxa of a country is to see value only in certain national values, and to eschew any notions of complexity or of different, but equally valid, national values and identities, then dismissals like that made by Mulcahy become the norm. Moreover, without reflexive thinking, which offers alternative perspectives that can, in turn, broaden the habitus in question, and ultimately transform the doxa so that different strands of the field become valued, then such dismissals are only the thin end of a wedge. It may seem a rhetorical and argumentative stretch to see language connected with location as causal of atrocities, but as Homi Bhabha has argued in The Location of Culture, where he talks about the 'hideous extremity of Serbian nationalism', the very idea of a pure, 'ethnically cleansed' national identity can only be achieved through the death, literal and figurative, of the 'complex interweavings of history, and the culturally contingent border-lines of modern nationhood.53

This is exactly what is being done in Mulcahy's dismissal of the national credentials of Peter Tyrrell: the border-lines of identity as defined by the Irish State are not sufficiently broad to include Tyrrell in any satisfactory or decent manner. There is no sense of apology for the horrors of Letterfrack or for putting someone 'through hell'. There is no reflective critique of a state and political system which would put one person in every hundred into religious care in orphanages, Magdalen Laundries and asylums. I would contend that a doxa which sees a rebellion as partly justified because it is poetic, or dramatic, is a doxa which is dangerously absorbed with a sense of a fictional image, an image which becomes exclusionary to those who are deemed 'un-Irish'. Edna Longley has made a telling observation on this issue:

Poetry and politics, like church and state, should be separated. And for the same reasons: mysteries distort the rational processes which ideally prevail in social relations; while ideologies confiscate the poet's special passport to terra incognita. Its literary streak, indeed, helps to make Irish Nationalism more a theology than an ideology .... it breeds bad politics - Fascism and Nationalism. But it also breeds bad literature, particularly, bad poetry, which in a vicious circle breeds - or inbreeds - bad politics. ${ }^{54}$

53 Homi K. Bhabha, The Location of Culture (London: Routledge, 1994), 5.

54 Edna Longley, Poetry in the Wars (Newcastle: Bloodaxe Books, 1986), I85. 
Longley is correct in her analysis of the concomitant and constituent factors in the doxa of Irish nationalism. It is through acts of metanoia, and of rupture, that such separations can be achieved.

By looking at different aspects of the field: at the dead children and women who had nothing to do with the rising, and at Peter Tyrrell, it is possible to come to a more mature and rounded sense of our past, and to avoid doxic attenuations and instead look at the more complex, uncertain and what Derrida might term spectral or hauntological aspects of the rising. The fact that brave Irishmen and women fought and died for an deal is not to be denied; but the context of this deed, which caused the deaths of a number of innocent people in the past is significant, as are the ramifications of an unexamined acceptance of the doxa of the rising for Republican actions in later times, down to the present day. Derrida's writing works:

to define and perpetually to redefine the meaning of inheriting without following, the meaning of accepting without repeating, the meaning of following even by betraying, and the meaning of setting to work an idea even while taking it in a different direction. ${ }^{55}$

Reflective thinking and deconstruction allow for the unpacking of the doxic field/habitus connection; a connection which forecloses debate, discussion and critique. They allow for a revision and a reconceptualization of patrimony and cultural heritage, which is no longer enunciated in the passive voice, or handed down by the past. In this paradigm, patrimony is no longer a given, but something to be, in Heaney's words, reimagined. Patrimony, in this dispensation, is no longer something that is handed down from the past; instead, it is reimagined in the present. In this conception of patrimony, there is room for the idealism of a number of men and women who took on an empire in the name of a concept of freedom, but as well as the story of Patrick Pearse, there is also room in this emancipatory notion of patrimony for Peter Tyrrell.

55 Susannah Radstone and Bill Schwarz, Memory: Histories, Theories, Debates (New York: Fordham University Press, 2010), I52. 



\section{Debt as Inheritance}

Like all our financial arrangements, and like all our rules of moral conduct in fact, like language itself - notions about debt form part of the elaborate imaginative construct that is human society. ${ }^{1}$

\section{Patrimoine and the Celtic Tiger}

Patrimoine/cultural heritage and indebtedness appear to be unlikely bedfellows in the context of contemporary Irish culture, yet bringing these terms into a constellation can prove illuminating as we interrogate parts of the creative and critical 'heritage' of recent Irish socio-economic history. The economics and the politics of the heritage industry have long proven problematic and divisive, as the financialization of the past, as well as the monetization of precarious territories, have engendered suspicion and attracted ire from invested constituencies in Ireland. But quite apart from the local irruptions of conflict within and around the heritage industry, the nature of 'heritage' itself is ripe for critique, as, we will suggest, it has taken on mutated and debilitating forms on foot of the demise of the Celtic Tiger. While the mainstream media has resumed its role as passive commentator on the partial recrudescence of Irish economic vitality, this belies the very real ways in which legacies of indebtedness persist for large numbers of citizens in Ireland, and, arguably, obscures the reality that debt has become a cornerstone of our national heritage. In a concise elucidation of the meaning of heritage,

I Margaret Atwood, Payback: Debt and the Shadow Side of Wealth (London: Bloomsbury, 2008), 203. 
Francesco Selicato, firstly, details, the Latin etymological roots of the term: '[heritage] derives from the Latin patrimonium, which is the union of two terms: pater (father) and munus (duty). The literal meaning is "the duty of the father" and, more extensively, the term can be translated as "things belonging to his father".' While there are obvious patriarchal implications attached to this etymological definition, for the purposes of our current discussion, it is the attention devoted to the possibility of inheritance that is of most concern. Selicato continues by suggesting that the aforementioned 'goods':

that belong to the father are evocative of value and sense. That breakdown still leads us to the conclusion, in a larger sense understood in an intergenerational key, that heritage is a set of goods that we have inherited from our fathers and that can be passed on to future generations. This definition inevitably places attention on the role that heritage must fulfill, a role that varies continuously between the passive deposit of historical memory or cultural identity and the powerful stimulus for creativity available for the present as well as for building the future. [My emphases] $]^{3}$

Selicato presents his etymological definition in largely apolitical terms, but in the context of our argument, the highlighted terms are acutely problematic. 'Heritage' is framed as a valuable and value-laden bequest across generations, a set of cultural reference points that both inspire and stabilize cultural identities in the present and towards the future. But what if that inheritance takes the form of entrapment in staggering indebtedness? Equally, what if the conditions and historical events that gave rise to that 'heritage of indebtedness' are narrated in terms that sanitize and/or fundamentally misread the genealogy of that debt economy? In these circumstances, debt is both an inheritance awaiting us in the future, but, equally, its origins are mystified by the construction of a retroactive 'heritage' narrative.

Within the spheres of cultural and political criticism the accruals and imprints of Ireland's economic buoyancy from the mid-I99os to the middle

2 Francesco Selicato, 'The Concept of Heritage', Francesco Rotondo, Francesco Selicato, Vera Marin, Josefina López Galdeano (eds), Cultural Territorial Systems: Landscape and Cultural Heritage as a Key to Sustainable and Local Development in Eastern Europe (Berlin: Springer International Publishing, 2016), 7.

Selicato, 'The Concept of Heritage', 7. 
part of the first decade of the twenty-first century, opinion is split between what Roy Foster terms 'Boosters' and 'Begrudgers.' In other words, there are those critics who heralded the Celtic Tiger as a potential source of cultural high achievement, and who saw the economic dynamism of the country as one fraction of a broader re-invigoration of Irish culture and society. In broader terms, a critical chorus emerged according to whose hymn-sheet the triumph of the Celtic Tiger is seen as fate; in other words, the utopianism of the late nineteenth and early twentieth centuries' revolutionary periods was the direct seed-bed for the prosperity experienced by the country a century later. In fact, what is palpable in certain histories of the Celtic Tiger - those that are broadly celebratory - is a form of inauguration. Bluntly, we are witness to the consecration of cultural and historical texts, and the monumentalization of moments, movements and personalities, and in what follows there is evidence of an effort to the establish a new critical heritage, a suite of historical and cultural lodestones through which to understand Celtic Tiger Ireland. Characteristic of this constituency, and underscoring one of the core axioms of the Celtic Tiger narrative, P. J. Mathews argues in his 2005 'In Praise of Hibernocentrism: Republicanism, Globalisation and Irish Culture', that '[w]ithin a decade Ireland has been transformed from a relatively impoverished backwater on the periphery of Europe, whose indigenous culture was constantly threatened by the homogenising influences of mass global culture, into a prosperous First World economy whose culture is increasingly being recruited to the global capitalist enterprise.5 For Mathews, this transition can be productively mapped by attending to the global scale of Irish cultural success; beginning in 1990 with the opening of Brian Friel's Dancing at Lughnasa. 1990 seems to be a key departure point in Mathews' chronology, but in many respects, it is as arbitrary and subjective as any other date. One could just as easily pre-date Irish cultural success to the late 1980 s with My Left Foot, The Commitments and the 1988 European Soccer Championships in Germany. The analysis also seems utterly dependent on a particular form of external ratification and/or

R. F. Foster, Luck and the Irish: A Brief History of Change, 1970-200o (London: Allen Lane, 2007), 7.

5 P. J. Mathews 'In Praise of Hibernocentrism: Republicanism, Globalisation and Irish Culture', The Republic: A Journal of Contemporary and Historical Debate 4 (2005), 10. 
legitimation. Nevertheless, for Mathews this point in time launches a swathe of Irish cultural achievements across film, dance, music, literature, comedy, which 'serves to illustrate Ireland's striking makeover on the global stage in the 1990 s from unfashionable Paddyland to land of cultural vibrancy'. This latter transition itself depends on the author's own assertion that Ireland was some species of antiquated 'Paddyland' rather than any objective evidence of the existence of such a phenomenon; likewise, quite what 'a land of cultural vibrancy' means, or did mean, is also excessively vague.

In a more historically expansive argument, but drawing upon Mathews' earlier work in Revival (2003), Declan Kiberd also equates 'cultural vibrancy' with economic wealth and prosperity. ${ }^{7}$ Providing a 'Cultural History of the Celtic Tiger', Kiberd suggests that the Celtic Tiger economy might well have facilitated and/or generated heightened cultural creativity. In his view this period was one of unprecedented opportunity for the arts, and in his estimation: 'The great renaissances of national culture in the past have flowered right across the globe against a background of economic confidence [...] If only we could bring the revivalist tradition of self-help once again into alignment with cultural pursuits, then the unfinished project of national renewal could come to fruition, and economics and art might harmonise.' Both parts of Kiberd's argument here chime with Mathews' assertions in his essay above and in Revival respectively, and, in essence, there is little wrong with aspiring towards a renewed sense of self-confidence across Ireland's national culture on foot of a more muscular economy. Yet what needs to be articulated, and remains unsaid in any great detail in these arguments, are the particular terms and complexities of Irish cultural and economic successes. In particular, Mathews does not address the possibility of, or in fact, the necessity for culture to act as a space for radical critique of or dissent in the face of a non-egalitarian capitalistic economic success narrative.

6 Mathews 'In Praise of Hibernocentrism', 9.

7 P. J. Mathews, Revival: The Abbey Theatre, Sinn Féin, the Gaelic League and the Co-operative Movement. (Cork and Notre Dame, IN: Cork University Press/Notre Dame University Press, 2003).

8 Declan Kiberd, 'The Celtic Tiger: A Cultural History', The Irish Writer and the World (Cambridge: Cambridge University Press, 2005), 287. 
Ireland might well have been a poster-child of cultural and economic achievement during the Celtic Tiger - according to Mathews and Kiberd respectively - but at what cost to the critical integrity of cultural resources and potentialities. While Kiberd does acknowledge that 'good novels, plays or poetry' can provide 'corrosive criticism of these developments', the celebratory narrative remains triumphant. ${ }^{9}$ Most alarmingly, Kiberd posits the following question: 'But why did it take a further seventy years for economic progress to catch up with attainments in culture and politics?' ${ }^{\prime 0}$ What such a query reveals is a remarkable neglect of the politico-economic transformations undergone by a newly independent state, prone to the vagaries of international capitalism and financialization. There is also a sense of inevitability palpable in Kiberd's idealistic connection of cultural and economic achievement, and it rather blithely accepts at face value the 'achievements' of the Celtic Tiger economy. It signally fails to track the demoralizing human relations that undergird the cultures of indebtedness and obligation attendant to the kinds of economic activity regnant during the so-called economic 'boom'. These critical precis of the origins of the Celtic Tiger, in sum, mediate our inheritance, they selectively re-shape and re-calibrate the events of the present into a narrative that retrospectively consecrates the contingencies of a particular period in Irish history. The contingencies of national and global histories are reified as national fate and as a species of national heritage.

\section{Debt as Patrimoine}

At a global level, there has been a plethora of critical interventions on the nature of the credit/debt economies within cultural and philosophical studies since the global financial crash in late 2008 , which illuminate the ways in which 'the overexposed, overindebted neoliberal subject has

9 Kiberd, 'The Celtic Tiger', 276.

Io Kiberd, 'The Celtic Tiger', 272. 
become one of the most representative figures of financial capitalism. ${ }^{11}$ Of particular relevance to the current discussion are the ways in which these engagements with the genealogies and politics of debt, and their relation to modern subject-formation, intersect with recent and ongoing representations of Irish economic affluence and subsequent austerity. As we shall encounter in detail, emerging theorizations of indebtedness are heavily indebted to previous work in this area by both Friedrich Nietzsche and Michel Foucault. From a thematic perspective, our argument will spotlight the ways in which debt is, and always has been, married to systems of discipline, moral instruction, as well as the politics of time. As Tayyab Mahmud usefully synopsizes:

Throughout history, debt both lubricated circuits of value extraction and acted as a disciplinary device. From Athenian debt-bondage to contemporary labour trafficking, debt-peonage has been part of labour management regimes of a variety of modes of production. The historical role of debt in moral discipline is evidenced by the fact that in all Indo-European languages, words for debt are synonymous with those for sin or guilt. ${ }^{12}$

For Mahmud, among others, debt is a fraction of Foucault's theorization of contemporary systems of 'governmentality', through which neoliberalism forms and regiments subjectivity. Dissent against and/or contradiction of the tenets and iterative demands of finance and market capitalism are confronted with the preventative realities of the widespread and enduring indebtedness of the contemporary economic actor. This 'responsible subject called forth by neoliberalism' is, according to Mahmud, 'the atomized and self-sufficient subject of the market'. In addition, this fact is enough to forestall disruptive and communally based 'projects of solidarity, collective rights, and antisubordination. ${ }^{13}$ Debt, like so much else under the

II Fiona Allon, 'Money, Debt, and the Business of "Free Stuff", The South Atlantic Quarterly II 4.2 (2015), 284.

I2 Tayyab Mahmud, 'Debt and Discipline', American Quarterly, 64.3 (2012), 482.

I3 Mahmud, 'Debt and Discipline', 485. See also, Silvia Federici, 'From Commoning to Debt: Financialization, Microcredit, and the Changing Architecture of Capital Accumulation', The South Atlantic Quarterly II3.2 (2014), 23 I-44. 
current politico-economic conjuncture, is privatized as both material and affective experiences.

As the anthropologist David Graeber clarifies in his sweeping genealogy of global historical ideas of 'debt', its logic is practically inescapable as it insinuates itself into, even becomes formative of, so many facets of everyday human culture and social interaction. In Graeber's terms: 'To tell the history of debt, then, is also necessarily to reconstruct how the language of the marketplace has come to pervade every aspect of human life - even to provide the terminology for the moral and religious voices against it. ${ }^{14}$ In this respect, debt becomes a fraction - a highly influential and oppressive fraction - of systems of value, worth and judgement. And what is most punitive in the contemporary (Irish) context in the new age of austerity is that debt is no longer a means of attaining the lavishly unattainable, but has become a form of interest-bearing social welfare, a means of filling the gaps vacated by the retreat of the welfare state. Thus, the present is dominated by shortage and subsistence, while the future is already mortgaged with the accumulated debts of distant strangers. ${ }^{15}$ The formation and future inheritances of this debt-conditioned historical continuum are caught by Richard Dienst in a formulation that chimes with the travails of Irish society over the past two decades. Implicit in Dienst's argument is the 'heritage of debt' that forms part of the legacy of Ireland's Celtic Tiger period, as he argues: 'the two great abstract machines that define our era - the market and the media - are two faces of this inscriptive-projective process, the organization of lived temporality around the interminable working-up and working-off of an imperishable indebtedness. ${ }^{16}$

I4 David Graeber, Debt: The First 5, ooo Years (New York: Melville House, 2011), 89.

I5 On the topic of temporality under modern capitalism, Martijn Konings argues: 'The rise of modern capitalism was accompanied by the emergence of a distinct experience of time, one in which humanity sees itself as making its own history, increasingly understanding present practices as having emerged out of its past presents and as shaping a contingent future,' 'State of Speculation: Contingency, Measure, and the Politics of Plastic Value', The South Atlantic Quarterly il 4:2 (2015), 255.

I6 Richard Dienst, The Bonds of Debt: Borrowing against the Common Good (London: Verso, 2011), I25. 
Before we address the immediate context indicated in the remainder of the title, we shall take a temporal and spatial turn to early twentieth-century Trinidad, to look at V. S. Naipaul's biographically derived and indebted $A$ House for Mister Biswas (1961). Naipaul's text addresses issues pertaining to debt-guilt, inheritance and literary form in differential ways, and it can act as a ready wedge with which to open a discussion of how such issues manifest in contemporary Irish writing, specifically Claire Kilroy's blackly comedic 2012 novel The Devil I Know. Towards the close of Naipaul's 1961 magnum opus Mohun Biswas is in ill-health and in debt on the house at Sikkim Street - the house he has spent all of his life attempting to secure. Of course, the house is deeply flawed in its structure, but the debt on its purchase remains constant. In consecutive paragraphs in the 'Epilogue', we read:

But the debt remained. At nights, with a clear view of the sky through the slightly crooked window frames on the top floor, he felt the time flying by, the five years shrinking to four, to three, bringing disaster closer, devouring his life. In the morning the sun struck through the lattice work on the landing and below the bar-room door into his bedroom, and calmness returned. The children would see about the debt [...] But the debt remained. Four thousand dollars. Like a buffer at the end of a track, frustrating energy and ambition. [My emphases $]^{17}$

There are two further mentions of 'the debt' in the final pages of the epilogue, as it seems to be a haunting presence in Biswas's declining months. With a degree of pathos, the guilt of this enduring debt, one that will and does outlive Biswas, is laid upon the foundations of his previous frustration at not being able to secure such a mortgage debt. But, as he reflects in the extract above, 'the children would see about the debt', could there be a more apt and resonant statement to conjoin the fictional experiences of Mohun Biswas and the indebted 'heritage' bestowed upon future generations in Ireland? Naipaul's protagonist leaves a legacy of financial burden far from the imagined stability that the house at Sikkim Street was supposed to endow. What is unsaid in critical commentary on the novel is that $A$ House for Mister Biswas could just as readily be re-titled as A Debt 
for Mister Biswas, for that is what he seeks - a home in indebtedness. If a house is a structure within society, its enabler, debt, is what structures so much of that society. Naipaul's novel is part picaresque, part Neo-Victorian tome - it channels humour, tragedy, ambition and frustration in its unsentimental depiction of Mohun Biswas's quest for a 'house'. But, of course, it achieves all of this with an adaptation of form, a transfusion of form with an altogether colonial content and context. We have already mentioned the structural foundations of Naipaul's novel, in terms of its indebtedness to the Victorian social novel, and the earlier picaresque narrative. However, in delving into the links between character, subjectivity, identity and social power - all centred on the acquisition of a house, a seat of integrity and an objective correlative of a fully realized subject-agency - Naipaul also invokes the unaccommodated figure of King Lear at a crucial juncture in the novel. Specifically, he offers the reader a twentieth-century Caribbean re-working of Lear's mental collapse on the heath.

Just as Lear is literally and figuratively unaccommodated in Shakespeare's tragedy, Mohun Biswas endures a similar fate in Naipaul's tragi-comedic renovation of and re-invention of homelessness in Trinidad. Both are refugees from productive time, Lear has aged beyond usefulness and is therefore scorned and abandoned by Goneril and Regan. And further akin to Lear, Biswas's relationship with debt is firmly linked to his children, by association with future possibilities and, ultimately, with what he can bequeath from one generation to the next. ${ }^{18}$ The two concluding references to debt are both directly related to his daughter, Savi and his son, Anand:

Suddenly the world opened for them, Savi got a scholarship and went abroad. Two years later Anand got a scholarship and went to England. The prospect of paying the debt receded. But Mr Biswas felt he could wait; at the end of five years he could make other arrangements [...] Anand said he wanted to come home. At once the debt,

In an insightful essay on the American context, Melinda Cooper concludes: 'neoliberalism has reinvented the poor law tradition in the idiom of intergenerational debt. We can only escape the tyranny of inherited wealth by including kin within our own debt servitude. It is this predicament, more than rampant individualism, which defines the experience of our times'. 'All in the Family Debt', Boston Review, May 2017, <http://bostonreview.net/class-inequality/melinda-cooper-all-family-debt>. 
the heart, the sack, the five years became less important. He was prepared to take on a further debt to get Anand home. But the plan fell through; Anand changed his mind. And Mr Biswas never complained again. [My emphasis ${ }^{19}$

Mr Biswas, for reasons at least partly sourced in the politics of caste and race, is frustrated in securing the means with which to indenture himself to propertied debt, and its associated temporal logic, until late in his life, and even then, this manifests in flawed form. Naipaul raises issues germane to the relationship between literary forms and crisis, to the ways in which older forms offer ways of confronting or processing apparently new forms of crisis. If Naipaul constitutes a kind of literary backdrop to the texts at the core of my argument, then Friedrich Nietzsche and Maurizio Lazzarato furnish our contentions with their theoretical logic. Historically separate they might be, but the aspects of their works that we draw upon are united by their concentration on the relationship between debt, guilt/morality and subject-formation. Now, it would be reductive to ignore the historical space that exists between the two, but there are ethical and philosophical commonalities that can effectively inform our readings of the literary text under scrutiny here.

\section{Debt and Guilt}

In the second essay of his On the Genealogy of Morality (1887), Nietzsche brings two key terms into alignment, when he poses the following question:

Have these genealogists of morality up to this point allowed themselves to dream, even remotely, that, for instance, the major moral principle 'guilt' [Schuld] derives its origin from the very materialistic idea 'debt' [Schulden] or that punishment developed entirely as repayment, without reference to any assumption about the freedom or lack of freedom of the will? ${ }^{20}$

I9 Naipaul, $A$ House for Mister Biswas, 586-8.

20 Friedrich Nietzsche, On the Genealogy of Morality, ed. Keith Ansell-Pearson (Cambridge: Cambridge University Press, 2006), 43. 
The framing terminology is illuminating here: morality and materialism are seen as rooted in the same idea - Nietzsche fleshes out the material experience of indebtedness with ethical consequence, and in turn with the capacity to influence, to direct and ultimately to contour human thought and subjectivity. Here we see the encroachment of the materialism of the debt economy onto the terrain of affect and emotion. ${ }^{21}$ But Nietzsche proceeds further; later in the same essay he spotlights a key feature of the morality and indebtedness: the production of the memory of that debt. He writes:

Precisely here, promises are made; precisely here, the person making the promise has to have a memory made for him: precisely here, we may suppose, is a repository of hard, cruel, painful things. The debtor, in order to inspire confidence that the promise of repayment will be honoured, in order to give a guarantee of the solemnity and sanctity of his promise, and in order to etch the duty and obligation of repayment into his conscience, pawns something to the creditor by means of the contract in case he does not pay, something that he still 'possesses' and controls, for example, his body, or his wife, or his freedom, or his life. [My emphases] $]^{22}$

The first highlighted section above references the notion of memory, but, of course, it really speaks to the future, and this is the creation of futurememory. The subsequent highlighted portion of the quotation re-iterates the links between indebtedness and morality - specifically the invocation of conscience - but surely, there are equal temporal considerations to this invocation of human conscience. There are recourses to precedence in any exercise of conscience; thus, time unites both memory and conscience in the active creation of the functioning moral subject in Nietzsche's view.

And this temporal context is only further re-enforced in the final highlighted section above. But what we also witness is the re-introduction of the materialism mentioned earlier. The material body, possessions, artefacts, affiliates are all mortgaged into the future through the assumption

2I Latterly in a related argument on financial investment, Annie McClanahan argues that 'even the most fictional forms of immateriality turn out to be inescapably historical and irreducibly material'. See, Annie McClanahan, 'Investing in the Future, Journal of Cultural Economy, 6.I (2013), 91.

Nietzsche, On the Genealogy of Morality, 40. 
of the debt in the present. Thus, the politics of debt and morality combine memory, cohere the present, future pasts, and future presents in the summoning and the shaping of the moral subject. What is worth considering is precisely where and how Nietzsche's writing on such issues is germane to recent discourse on indebtedness and responsibility following the global economic crash. How has this crash, and the relative attributions of blame, guilt and responsibility been processed globally - and of course mediated culturally and artistically, specifically in Ireland? However, guilt is not confined to the post-crash landscapes of Ireland; as Nietzsche indicates, the symbiosis of debt and guilt are endemic to any and every social and economic relation. Nevertheless, perhaps this is more acutely visible in a society/economy that rushes headlong into the grips and opportunities promised by indebtedness.

The Paris-based, Italian sociologist, Maurizio Lazzarato has produced two recent books on the contemporary relevance of Nietzsche's writing on the creation of what Lazzarato has dubbed 'indebted man'. Lazzarato's work is also informed by the work of Michel Foucault and Deleuze and Guattarri, and their work on the body politics of capitalism. ${ }^{23}$ Lazzarato's two recent works are successively The Making of the Indebted Man (2007) and Governing by Debt (2013). ${ }^{24}$ Early on in the former, Lazzarato, echoing Nietzsche, situates morality and economic responsibility within a protracted historical continuum. He writes: 'We are no longer the inheritors of original sin but rather of the debt of preceding generations. "Indebted man" is subject to a creditor-debtor power relation accompanying him throughout his life, from birth to death. ${ }^{25}$ Lazzarato operates on two different temporal planes here. The latter portion is confined to the limits of the human life-span. The normative life-span is burdened by the power relations extant in the world, and these relations are fundamentally and

23 On Lazzarato's work, see James Muldoon, 'Lazzarato and the Micro-Politics of Invention', Theory, Culture \& Society 31.6 (2014), 57-76.

24 Maurizio Lazzarato, The Making of the Indebted Man: An Essay on the Neoliberal Condition (Los Angeles, CA: Semiotexte, 2007), and Maurizio Lazzarato, Governing by Debt (South Pasadena, CA: Semiotexte, 2013). 
inescapably centred on the economic parameters of the debt economy. But the earlier point signals Lazzarato's interest in more extended historical patterns, and also introduces the notion of haunting to our consideration of the relationship between the subject and indebtedness. In a sense, we are not only shadowed and haunted by our own contemporary debt relations, but we are the legatees of previous cycles and relations of indebtedness, and in our turn we will leave our debts for future legatees. All things considered, in fact, there are Gothic overtones to the ways in which the Irish landscape and economy are haunted by our individual and combined indebtedness.

Thus, the guilt of indebtedness precedes our births and outlives us after our deaths, and for Lazzarato, as for Nietzsche, is structural to the formation of the modern subject. We must operate, we must come to consciousness, through the internalization of indebtedness, together with the moral and the affective demands of such indebtedness. As Lazzarato continues slightly later in The Making of the Indebted Man: 'Debt therefore implies subjectivation, what Nietzsche calls the "labor of man on himself," a "self-torture". This labour produces the individual subject, a subject answerable and indebted to his creditor. ${ }^{26}$ Lazzarato's employment of the term 'subjectivation' is provocative, in the sense that it chimes, variously, with Foucault's and, latterly, with Judith Butler's use of the term in relation to the politics of gender performance. ${ }^{27}$ Lazzarato's deployment of the term suggests that indebtedness is part of the iterative process through which subject identities and functions are brought to coherence. The debtor/creditor relational axis, then, is the basic unit of this iterative process, which, to return to our temporal conceit, patterns consciousness and conscience in the present and into the future. For Lazzarato: 'The debtor-creditor relationship [...] intensifies mechanisms of exploitation and domination at every level of society, for within it no distinction exists between workers and the unemployed, consumers and producers, working and non-working

26 Lazzarato, The Making of the Indebted Man, 42.

27 Butler has written on the performative nature of the market economy. See Judith Butler, 'Performative Agency', Journal of Cultural Economy, 3.2 (2010), I47-6I. 
populations, retirees and welfare recipients. Everyone is a "debtor," accountable to and guilty before capital. ${ }^{28}$

Performance and guilt, then, are integral to the procedures of the contemporary debt economy; the internalization of a guilt relation between debtor and creditor establishes the ground upon which the contemporary subject of liberal capitalism iterates and re-iterates their identity. This relation configures the temporal and spatial terrains of subject-performance, harnessing desire, memory and agency, and commanding authority over the interpersonal and narrative relations of the future. Aggregating Nietzschean and Foucauldian registers, Lazzarato continues by underscoring the imbrication of debt, morality and futurity in the convention of the productive - the self-productive - subject, or what James Muldoon describes as 'the production of a particular form of [...] subjectivities' amenable to the biopolitical operations of capitalism. ${ }^{29}$ In the patois of investment banking: past performance must be an indicator of future performance, or in Lazzarato's terms: 'The debt economy is an economy that requires a subject capable of accounting for himself as a future subject, a subject capable of promising and keeping a promise, a subject that works on the self.' ${ }^{30}$

\section{Debt and Inheritance in Claire Kilroy's The Devil I Know}

Published in 2012, Claire Kilroy's The Devil I Know, combines straight literary realism with elements of genre fiction in its retrospective narration of the machinations and the decline of Ireland's property surge. Indeed, Kilroy's employment of the tropes of genre fiction are fundamental to her work's critique of many of the economic and political mores of Celtic Tiger Ireland. As critics have noted, genre fiction undercuts the apparent stability and conservatism of mainstream literary realism, thus offering a

29 Muldoon, 'Lazzarato and the Micro-Politics of Invention', 66.

30 Lazzarato, The Making of the Indebted Man, 88. 
series of formal opportunities with which interrogate the 'reality' of neoliberal capitalism. As Hamilton Carroll and Annie McClanahan suggest: 'Moving across literary or cultural types, genre narrative provides a formal and epistemological logic that destabilizes definitional boundaries and precisely mirrors the disruptive mobility of financial global capital itself ${ }^{31}$ Kilroy's narrative relates the events surrounding Tristram St Lawrence's immersion in the nether regions of Ireland's credit/debt economy at the outset of the twenty-first century. On returning after a prolonged absence from Ireland, Tristram encounters an erstwhile acquaintance from his schooldays, Des Hickey, who inveigles Tristram into partnering him in a thoroughly ambitious, and outsized, property investment. However, Tristram's decisions, and indeed agency, are guided by his AA 'sponsor', Mr Deauville, who is only contactable remotely by phone. In addition, it is through this narrative device that Kilroy transcends the conventions of literary realism, and invests her narrative with Faustian textures. Early in novel, our protagonist and narrator, Tristram, is being driven on the coast road above Dublin Bay by his future business associate, Desmond Hickey, and he provides the following portrait of his environment:

The truck ascended past ponied meadows and heathered slopes until the road crested
and Dublin Bay appeared below, broad and smooth and greyish blue, patrolled by
the Baily lighthouse. The whitethorn was in full blossom and the ferns were push-
ing through. Better to have been born somewhere dismal, I sometimes think. Better
to have grown up shielded from striking natural beauty, to have never caught that
glimpse of Paradise in the first place only to find yourself sentenced to spending the
rest of your life pining for it, a tenderised hole right in the heart of you, a hole so big
that it seems at times you're no more than the flesh defining it, I rolled the window
up to seal the beauty out.

What commences as a vision hewn from the conventions of romantic lyricism - with its congregation of alliterative and assonant sound effects declines into an introspective confrontation with humanity's capacity for

3I Hamilton Carroll and Annie McClanahan, 'Fictions of Speculation: Introduction', Journal of American Studies, 49.4 (2015), 661.

32 Claire Kilroy, The Devil I Know (London: Faber and Faber, 2012), I6. 
destruction and with the transience of human life. The latter are, of course, germane to the present discussion, and with the ecological imprints that score the post-Celtic Tiger landscapes across Ireland. Nevertheless, of equal interest is the way in which time is figured in this brief section of Kilroy's narrative; there is an association of such natural beauty and efflorescence with the past but also with impossibility. But in this case we do not necessarily associate this with a mystification of the past and of landscapes attached to such anterior temporal distance. Rather, Tristram's reflection is at least partly directed at the history of the recent past, with the history of the present moment. Equally, Kilroy sets up a traffic between the externalities of non-human ecologies and natural landscape and the machinations of human subjectivity, as the passage moves from outward-oriented observation to inward self-reflection. This can be figured in two ways at the same time; it signals the mutuality of landscape and humanity at physical and affective levels, but, also, gestures to the means through which we abstract and objectify the physical externalities of the non-human.

We also notice from the previous passage that the narrative is presented in the first-person singular in the past tense, which at one level is continuous with our concentration on temporality thus far. However, of more significance at the level of form is that Kilroy's use of such focalization is a necessary function of the broader narrative structure. The core narrative framework employed by Kilroy is that of the legal trial - a choice that explicitly coheres with our focus on the notions of guilt, debt and form. In addition to the framing form of the court trial, The Devil I Know also incorporates elements of and allusions to Gothic, Faustian, Kafkaesque and Big House narratives; narrative forms that clearly can accommodate confrontations with inheritance, debt and guilt in their own rights. As with any trial, the narrative is haunted by events from the past, the narrative is, then, a reckoning with previous choices made and actions committed by Tristram St Lawrence. Furthermore, the trial conceit offers Kilroy the opportunity to address directly, or to allude to, issues such as: trust, truth, responsibility, inheritance and, naturally, guilt. All trials are excavations of the past inheritances, as well as interrogations of the self, of a self, which lead to the attribution of guilt, the acquisition of truth or the confirmation of innocence. But Kilroy's adoption of such a form also plays with 
the pagination and the typographical consistency of the novel form itself; this is the only text that appears on the first page of the novel: 'First day of evidence ro March 2016', page 2 is blank, while on page 3 we simply read: 'Please state your name for the record'. From Kilroy's perspective, then, the novel is cast four years into the future, which in itself is a suggestive narrative strategy in terms of our titular foci. Combined with the satirical tone of much of the narrative, the proleptic form appears to imply that no such conclusive legal or even ethical restitution will occur in Ireland - a prescient conclusion by Kilroy. Nevertheless, of more relevance to this chapter is the idea that the past, in the form of the period of the Celtic Tiger itself, and the future, in terms of political and economic fall-out, as well as continued individual, personal indebtedness, cannot be disaggregated, either in practical or moral terms.

Tristram answers what appears as a depersonalized request for his name, and the tone of his response to the sternly posed question demonstrates the manner in which Kilroy appropriates the architecture of the court trial for her satirical narration of the very absence of accountability during the Celtic Tiger property frenzy:

Don't be coy, Fergus. You've known me since I was yay high. I beg your pardon? Oh. It's like that, is it? I see. Very well. As you wish. This is going to take longer than expected, but then, you lot are running on a pricey meter. Two and half grand a day, I hear. Well Fergus - I mean Justice O'Reilly - my name, for the record, is Tristram St Lawrence. Tristram Amory St Lawrence, the thirteenth Earl of Howth, Binn Eadair, hill of sweetness. I was - I am - the only son your old pal, the twelfth Earl of Howth, managed to sire, and not from lack of trying. People have been saying a lot of bad things about me in the press. I am here to say a few more. ${ }^{33}$

The reference to 'Tristram Amory Lawrence' recalls the novel's epigraph, which is taken from Finnegans Wake: 'riverrun, past Eve and Adam's, from swerve of shore to bend of bay, brings us by a commodius vicus of recirculation back to Howth Castle and Environs. Sir Tristram, violer d'amores, fr'over the short sea, had passencore rearrived from North Armorica on this side the scraggy isthmus of Europe Minor to wielderfight his penisolate 
war. ${ }^{34}$ Thus Kilroy's protagonist is directly related to the opening of Joyce's modernist masterpiece, as well as to the historical founder of Howth Castle, Sir Amory Tristram. At an allusive level, this obviously coheres with the temporal foci of our discussion; but Kilroy's allusiveness also flags up the novel's interest in time, history and the past as kernel thematics. The first sentence of the same quotation reappears in the final chapter of the novel, this time with more darkly ironic connotations and associations:

riverrun, past Eve and Adam's, from swerve of shore to bend of bay, brings us by a commodius vicus of recirculation back to Howth Castle and Environs. Do you remember? It used to be written on the tenner back when we had our own currency. On O'Connell Street preparations were afoot outside the GPO for the celebration of the Centenary of the Easter Rising. One hundred years since the Proclamation of the Irish Republic and our sovereignty had been hocked. ${ }^{35}$

In repeating the quotation, Kilroy obliquely echoes Joyce's own formal innovation in Finnegans Wake, where the opening sentence of the text is the end of the final sentence of the text, thereby drawing our attention to the novel's concern for historical repetition and temporal circularity. However, it is the two highlighted lines that are of most importance in the current context, as they relate directly to the politics of debt, as we encountered in Nietzsche and Lazzarato.

In this case Tristram refers to the stripping of national economic, and therefore de facto political, sovereignty - but the chapter, and the novel, quickly move to a close with the dramatization of Tristram's own personal reckoning with debt, which, naturally, as we have seen, involves the denial of agency and freedom into the future. And this is the point at which the Faustian, and less overtly the Big House, formal patternings of Kilroy's narrative are rendered most visible, and where the idiom of indebtedness is clearly linked with guilt and punishment. As Tristram returns to his ancestral/family home for the final time, he describes the scene of aftermath that presages his imminent fate; in this respect the anteriority of the Big House narrative strand anticipates the imminence of the Faustian plot's denouement: 
I crossed the road to the ribbed columns of the castle entrance. Sir Tristram has passencore rearrived. [...] Windows were broken and roof slates missing. A buddleia sprouted from the chimney stack and the garden was a poisonous ragwort thatch $[\ldots .$.$] the gatekeeper's cottage was a derelict wreck and so was I. [...] I went around the$ back. The castle was boarded up like the rest of the county. A carpet of bindweed had smothered the sunken gardens. I paused at the tradesman's entrance but continued around to the vandal's entrance and climbed through that instead, seeing as I was the biggest vandal of them all. They had pulled off the plywood boards and broken the catch on a sash window. Cider cans littered the parquet floor like autumn leaves. ${ }^{36}$

In this extended fraction of the narrative, once again Joyce is explicitly invoked as colonial inheritances and contemporary histories are about to reach points of settlement. Indeed the use of the Joycean quotation is a moment of internal and external repetition - we have seen it before within this text, and it allusively reaches back to Joyce. It speaks, then, to both the past and the future within Kilroy's novel, but, of course, it also does in Finnegans Wake, as Joyce's original speaks to the future arrival of Sir Tristram.

But this is also a quintessential site of dereliction, a fragmented and anachronistic edifice whose original purpose and proprietors have been superseded by the appetites and the machinations of Ireland's integration into globalized liberal capitalism and the debt/credit economy. The reference to boarded up properties is an explicit invocation of the blight of ghost estates across Ireland, but more poignantly, it signals Tristram's ultimate alienation from history and, in the end, from the site of his patrilineal, Big House inheritance. Through his actions, through his complicity with and exploitation by the alchemists of debt, he is compelled to witness the decline and abandonment of his familial home and the histories attached to that property. His inheritance has been rendered as a dilapidated legacy to future generations; along with the partially completed and now redundant site on which he and Des Hickey had planned to erect their hotel and apartments, it is a debt that must be met in the future. But in figuring himself as a 'derelict wreck', Tristram internalizes the dereliction of the country and of his ancestral home, and, therefore, it is also suggestive of the ways 
in which debt is internalized and is formative in process in subjectivation. As we have seen with both Nietzsche and Lazzarato, the debt economy is not confined to external physicalities and operations, but performs work in the hailing and the formation of the subject, more pointedly, of homo economicus.

So, while physical manifestations of the debt economy are readily identifiable, bricked and mortared signs of indebtedness, as we have just mentioned, we need to remain mindful of the more pernicious affective consequences of the debt economy. And it is with such thoughts in mind that Kilroy draws the narrative to its resolution, with the Faustian pact made by Tristram bringing his life and career to an end. Speaking about the trials and excesses of Tristram, a character referred to as the historian - in fact the Devil - summarizes Tristram's actions and downfall:

'The benighted fool had squandered everything, you see. Every last farthing and more besides. What past generations had laboured to create, destroyed just like that'. The historian clicked his fingers. 'A whole way of life gone. He racked up a debt that can never be settled. But a debt must be settled, mustn't it? Isn't that the nature of debt?' [...] Deauville had come to collect. A debt must be settled. That is the nature of a debt. The Devil linked my arm and we began our descent. ${ }^{37}$

The initial highlighted text here tallies with the trope of decline seen earlier, from the decline of the Anglo-Irish from whom Tristram is derived, to the eminence and decline of the property merchants of contemporary Ireland. Kilroy's use of Joyce is not to resolutely express her faith in the cyclical patterns of conquest and defeat, or to make a fatuous or facile analogy between the two historical periods. Rather she gestures to the rhythms of history that structure the essential precariousness and transience of hubristic power. The latter highlighted sections above suggest that while the edifices and wealth of individual owners and speculators in any given historical period are transient and vulnerable, what does endure is debt and the requirement that it be paid in the future. The insistent pairing of 'debt' and 'settle' here is noteworthy; the etymological origins in Old and Middle English of 'settle' are associated with place, or a sense of rootedness 
or rest. Thus, this adds a spatial layer to our already well-established temporal readings of debt. But equally, there is an incontestable inevitability to the so-called 'nature of debt' here; it outlasts and supersedes the actions and agencies of the subject that incurs the debt, and it bequeaths both the materiality of the debt together with the underlying guilt to future generations. Tristram, then, like us all, cannot elude the demands of his Faustian pact with the prevailing, dominant debt economy; the moral pole attached to sin and punishment ushers our protagonist to his fate. Mr Deauville/ the Devil guides Tristram to his Hadean future where he is sentenced to perpetual atonement for his profligate accrual of debt through misguided property investment. Futurity and morality coalesce under the sway of the debt economy - both in contemporary Ireland and in Kilroy's fiction. And in the end we not only bequeath the materiality of our indebtedness as heritage to future generations, but we enculturate our legatees into, what Michael Cronin has called, ' $[t]$ he logic of debt. ${ }^{38}$

38 Michael Cronin, 'Ireland's disappeared: suicide, violence and austerity', Ireland under Austerity: Neoliberal crisis, Neoliberal solutions, eds Colin Coulter and Angela Nagle (Manchester: Manchester University Press, 2015), I 40. 



\title{
3 'We did not choose this patrimony': Irish Musical Inheritances since Independence
}

\section{Introduction: Strategic Silences}

\begin{abstract}
'We did not choose this patrimony, sir / And are dismayed by the inheritance. / The more so since you died intestate'. Aidan Mathews' 'Answer' to W. B. Yeats, published in his 1977 collection, Windfalls, surfaced from the sunken stores of memory when I first sat down to think about this topic. ${ }^{1}$ In truth, the word 'patrimony' in that poem seemed like a tiny salute or nod in the right direction, and I hope it may be so. I have long admired Mathews' poetry and his superb short stories, and I once compared his quandaries as a writer to those of the German composer, Robert Schumann, in a piece published thirteen years ago. I won't rehearse those quandaries (or the comparison itself here), except to remark that my essay appeared in a collection entitled The UCD Aesthetic, edited by my former colleague, Tony Roche. ${ }^{2}$ The UCD Aesthetic sounded like a contradiction in terms to me back then, and it does still. However, I was taken nevertheless by the seam of Irish writers whose work Roche and his contributors surveyed in that book: they include Newman, Hopkins, Joyce, Austin Clarke, Denis Devlin, Tony Cronin, John McGahern, Joseph O’Connor, Emma Donoghue and
\end{abstract}

I This chapter originated as a keynote address at the Association of Franco-Irish Studies conference which took place at Mary Immaculate College, University of Limerick in May 2017. I am most grateful to Eamon Maher and Eugene O’Brien for having invited me to be part of this memorable event.

2 See Harry White, 'Aidan Carl Mathews', in Anthony Roche (ed.), The UCD Aesthetic. Celebrating I5o Years of UCD Writers (Dublin: New Island, 2005), 239-45. 
Conor McPherson as well as Mathews and several others. I was impressed by the prominence of poetry, fiction and drama in the afterlives of writers connected to the university in which I have spent so much of my own working life (man and boy, as it has unexpectedly transpired). Mathews' poem, characteristically laconic, well-wrought and adept in its mild provocations, seems to me more and more plausible as an answer to Yeats as the years go by. It falters before the legacy of Yeats, but it recognizes the indiscriminate largesse of the estate itself. To be an Irish poet after Yeats may once have seemed a fate similar to the destiny of those Romans who sought dishonourable graves in the shadow of Caesar's colossal stride (the same anxiety haunted German composers after the death of Beethoven), but the estate itself proves otherwise. Irish poetry, like German music, recognizes a thriving gallery of masters, at work in the world at large.

I found the Mathews poem - which I hadn't read for over twenty years - in the first edition of The Field Day Anthology of Irish Writing, edited by Seamus Deane in 1991. ${ }^{3}$ It is one of the last poems included in that imposing compendium. In reading for this chapter, what struck me when I consulted the poem in its Field Day context was not the astonishing (and abiding) currency of so many Irish writers from the twentieth century in our own day. Nor was it the omission of so many others, which is to say women writers, from Deane's purview, a deficiency which prompted two further Field Day volumes edited by Angela Bourke and seven co-editors in 2002 and $2003 .{ }^{4}$ Instead, what really struck home was the extent to which the Irish literary canon has grown in the (almost) twenty-seven years since Deane's original anthology appeared. Given the readership, critical apparatus and media presence which attaches to contemporary Irish writers, and given (in brief) their prodigious circulation and sheer prominence domestically and across the globe, we are entitled, I think, to observe that

3 See Seamus Deane (general editor), The Field Day Anthology of Irish Writing (Derry: Field Day Publications, three vols, 1991). The Mathews poem ('An Answer') appears in Volume 3 ('Contemporary Irish Poetry', edited and introduced by Declan Kiberd), I 427 .

4 See Angela Bourke et al. (eds), The Field Day Anthology of Irish Writing, Vols. 4 and 5. Irish Women's Writing and Traditions (Cork: Cork University Press, 2002). 
the Irish literary canon is not only alive and well but expanding at such a rate that an anthology or cabinet such as The Field Day project, when we reconsider it a quarter century (and slightly more) after it first appeared, retrospectively indicates how completely the Irish literary landscape has changed in the meantime.

For example, neither Colm Tóibín nor Emma Donoghue nor Patrick McCabe are in the 1991 Field Day Anthology. There is a hint of Sebastian Barry (some poems), but none of the fiction which was later to make him such a prominent novelist (to say little of his work as a dramatist). Field Day comes before most of the work of Roddy Doyle and Joseph O'Connor (neither of whom it includes); it pre-dates the emergence of Martin McDonagh, Conor McPherson and Marina Carr. It does not anticipate the original screenplay and film adaptation, which - whatever else they might survey now claim our attention as genres of Irish writing. The burgeoning condition of literary fiction, poetry and drama as an expression of contemporary Irish culture is unmistakable. The constituency of interest, which gives this life and circulation, is alert, responsive and commensurately worldwide. The novel, the poem, the short story, the play, the screenplay: all but one of these genres has a very long history, and all of them are freshly imbued and reimagined in the high noon of Ireland's current and vastly prolific literary estate. I have remarked more than once that Ireland's claim to serious art lies most securely within the writer's canon, one of such magnitude and incremental interest that its formative influences easily compare - at least in Europe and North America - to that of the Austro-German musical canon in the long nineteenth century. They had Mozart, Beethoven, Schubert, Brahms and Wagner; we have Yeats, Joyce, Beckett, Friel and Heaney. And that's just for starters. ${ }^{5}$

Even if not everything in the Irish writers' garden is rosy (or even if we add that roses have thorns), the botanic luxuriance which this garden affords invests the word patrimoine with such a plenitude of meaning that the mere taxonomy of Ireland's literary estate is difficult to comprehend. (It

$5 \quad$ For a more detailed comparison between Irish writing and European music in relation to canon formation, see Harry White, Music and the Irish Literary Imagination (New York and Oxford: Oxford University Press, 2008). 
becomes more difficult still on account of the mixed metaphors that loom [and bloom] in that last sentence). However, my meaning is nevertheless (I trust) clear: since Independence, the prestige and currency of Irish literary culture has been impressively incremental.

It would be fatally easy to suppose that this has been at the expense of Irish musical culture, but when we consider the question of heritage or patrimony in relation to music over the past century and specifically since Independence, the condition of Irish musical inheritances presents a very different reading. Here is Axel Klein in the course of his essay on Irish music between 1923 and 195I in The Invisible Art: A Century of Music in Ireland, $1916-2016$ :

I have sometimes been tempted to write a history of Irish music describing the music and nothing else, using as background the history of European classical music and nothing else. No politics. No religion. A consciously naïve approach. It is a tempting idea. As things stand, however, we must find an explanation as to why the majority of Irish people seem to think they have no history of classical music. It is easy, and obvious, to find reasons in the history of Ireland as a British colony. Independent Ireland undertook many steps to decolonise itself after independence by removing relicts [sic] of its colonial past (think of the destruction of country 'demesnes' and Georgian architecture) and emphasising Gaelic names and customs. It is less easy to explain why, in the field of literature and drama, the names of Protestants such as Shaw, Wilde and Yeats (not to speak of Swift and Goldsmith) were reclaimed for Ireland, while in music Protestant names are still viewed with suspicion - even more so in newly independent Ireland. Imagine Irish drama without Shaw, Yeats, Synge, O'Casey and Beckett, and you arrive at the situation we have in music. ${ }^{6}$

I don't disavow this diagnosis as far as its general argument goes, but it seems to me insufficient nonetheless to deplore the strategic silences which have enveloped art music in Ireland as a more or less conscious programme of decolonization. There's no doubt that the idea of heritage in other departments of Irish culture has been afflicted by a degree of neglect which (in the long aftermath of actually burning country houses down to the ground), endures to the present day. Walking down Henrietta Street and North Great

6 See Axel Klein, 'No State for Music' in Michael Dervan (ed.), The Invisible Art: A Century of Music in Ireland, IgI6-20I6 (Dublin: New Island, 2016), 47-68; here, 48. 
George's Street in Dublin a few months ago, I couldn't help noticing the shambolic condition of row upon row of boarded-up Georgian houses, to say little of the state of Parnell Square or the Alice doesn't live here anymore flavour of O'Connell Street, whose shop fronts and gambling joints are more reminiscent of the set of Midnight Cowboy than of a European capital thoroughfare. And one could, I suppose, transfer this casual indifference (and rude modernity) to the reception of Ireland's musical inheritances in similar terms. These inheritances, it is true, are scarcely of interest to anyone beyond the borders of a very recent scholarship which has sought to retrieve them, so that even their sources remain obscure and silent. I am still resistant to the idea that Ireland before Independence can be read as a colony (and certainly not in a formal sense), even if it is by now difficult to swim against the tide of postcolonial theory as this applies to the infrastructural and civic amenities of Irish life between I880 and 1920 (to look no further in either direction), given the almost axiomatic temporizing of London governments in relation to Ireland's claims to political as well as cultural autonomy which undid John Redmond immediately before and during the Great War. In any case, it is almost impossible to resist those postcolonial readings of Irish culture which emanate from Field Day itself, especially when they are refined by critics such as David Lloyd, who argues so impressively (despite Ireland's post-independent literary prestige) in favour of a colonial dislocation of its essentially oral culture. ${ }^{7}$

I don't wholly accept this argument (if only because the extant legacy of Irish writing in English decisively subverts it), but the oral/written, native/colonial, indigenous/imperial dialectic through which Lloyd (and Deane) inscribe their readings of Irish cultural history draws music into its orbit, or it would, if anyone thought to engage with this dialectic in musical terms. Over thirty years ago, Seamus Deane construed Yeats's idealism as an imagined continuity between Ascendancy thought and his own poetic, but this has not impeded or reduced the reception history of

7 See David Lloyd, Irish Culture and Colonial Modernity, I800-2000: The Transformation of Oral Space (Cambridge: Cambridge University Press, 2011). 
Yeats's poetry (the plays are a different matter) in the smallest degree. ${ }^{8}$ Even when we contest Yeats's visionary readings of Irish history, we perpetuate the currency of his finest poems. Roy Foster's recent readings of 'Easter 1916' (as differently constructed from Deane's Yeats as one could imagine) are a well-known case in point. ${ }^{9}$ Whatever else we may attest about Ireland's literary heritage, we cannot suppress the self-evident truth that its international currency is English. I don't make this mild observation (it is hardly even that) to disparage the rival claims of literature written in Irish, but I do think it worthwhile to point out that, as far as ideas of heritage are concerned, the music we have preserved and reanimated in this country is also written (as it were) in the same native tongue, or as an expression of its cultural bearings. This, in fact, is the patrimony we have chosen. And it is the implications of this choice that preoccupy me in what follows here.

\section{Traditional Music and the Eclipse of Europe}

One feature of Axel Klein's roll-call of productive Protestants (Shaw, Yeats, Synge, O'Casey and Beckett), is that the religious denomination itself means next-to-nothing, even if we adduce what Deane memorably described as the 'most seductive of all Yeats's historical fictions' in relation to Yeats

See Seamus Deane, Celtic Revivals (London: Faber and Faber, 1985), Chapter 2 ('The Literary Myths of the Revival'), 28-37.

9 See Roy Foster, Vivid Faces. The Revolutionary Generation in Ireland I890-1923 (London: Allen Lane, 2014), 19-24 and 331-3. Foster provided an extensive historical gloss on the poem in his lecture 'Knowing their dream? Yeats' response to Easter 1916', delivered as a public discourse in the Royal Irish Academy, Dublin, on II January 20I6. Perhaps the intimacy between Irish poetry and history (plentifully in evidence both during and after Foster's discourse) accounts in part for the currency of such poems (notwithstanding the immediate topicality of the centenary of the revolution). 
himself. ${ }^{10}$ The imagined empathy between peasant and Anglo-Irish nobility, which Yeats discerned (or invented) would not have survived a religious discrimination between these two abstractions, even if it had occurred to him to insist upon it. And as soon as we admit Joyce to this exalted company the question of religion is radically re-configured in any case, because Joyce's modernism is exemplary in its preoccupation with urban Ireland (with Dublin, in brief) as subject-matter. This in turn privileges Roman Catholicism as a vital conduit of Joyce's fiction (his Protestant avatars are usually ephemeral, faintly ridiculous or grotesque as occasion demands), even or especially when music occurs to him. ${ }^{11}$ So other agents must be in play when Klein identifies Protestantism as a vaguely defined but deeply felt impediment to the nurturing of art music in the aftermath of Independence. The reduction of serious music to the margins of a fading Anglo-Irish polity has had a long run in the unwritten or eclipsed cultural history of this country. When I was a child studying theory at the Royal Irish Academy of Music, my teacher, gentle Miss Moore (who was English) would say things like, 'Oh, I say. You are up a gum tree!' whenever something went astray with my harmony exercises. This sounded mildly exotic and certainly foreign to my lower middle-class, Catholic sensibilities, like a faint echo of Joyce's reaction to the word 'tundish' in the mouth of the Dean of Studies in A Portrait of the Artist as a Young Man. But this mild alienation in relation to European music is hardly an explanation for its uneasy passage as Ireland attained autonomy as a nation-state, especially given the assimilation of 'classical music' in the religious orthodoxies of Irish national education. ${ }^{12}$

This, according to Deane, was 'the gift of dignity and coherence to the Irish Protestant Ascendency tradition'. See Deane, 'The Literary Myths of the Revival', 28.

II Late in Ulysses, Bloom is thinking about church music and ponders that 'he infinitely preferred the sacred music of the Catholic church to anything the opposite shop could offer in that line such as those Moody and Sankey hymns or Bid me to live and I will live thy Protestant to be'. See James Joyce, Ulysses (London: Oxford University Press, $1992[1922]), 770$.

I2 I might add in passing that this process (in which Roman Catholic priests and nuns promoted 'classical' music as an expression of social conformism) has been little researched to date. 
'The more we foster modern music, the more we help to silence our own' (Richard Henebry in 1902) is among the best-known of those chauvinistic pieties which remaindered the European aesthetic not only as an irrelevance to Irish cultural retrieval, but as its enemy. ${ }^{13}$ What we might term the 'argument from purity' (akin to the 'argument from design' as a proof for the existence of God) went a long way in the periodical debate which surrounded Irish music in the early twentieth century, and this, too, helped to silence whatever claim Europe might have on the nation's musical affairs. ${ }^{14}$ In 1905, W. H. Grattan Flood - who was the last person to enterprise a history of Irish music without foundering upon its 'either/ or' complexion as an obstacle to narrative intelligibility - immersed himself nevertheless in an untenable (not to say fanciful) 'battle of two civilizations' (one lost, the other ascendant) which not only deepened the myth of Catholic genius subverted by Protestant dominion (he ascribes to Gaelic musical culture the invention of counterpoint, sonata form and antecedents for western plainchant, to name some of his more choice improbabilities), but which privileged Irish traditional music as an agent of cultural redemption, waiting in the wings, as it were, like a Jacobite pretender to the throne. ${ }^{15}$ One might conclude that in the end, Grattan Flood was worn out with waiting (although his prodigious - if sometimes erratic - contributions as a musical antiquarian have received less than their due), ${ }^{16}$ but he was in any case overtaken by a cultural modernism which

I3 See Richard Henebry, Irish Music (Dublin: An Cló-Cumann, c. 1903), I4. Henebry was Professor of Old Irish at University College Cork from I909 until his death in 1916.

I4 For a reading of music in Ireland which privileges this debate see Harry White, 'Synge, Music and Edwardian Ireland' in Brian Cliff and Nicholas Grene (eds), Synge and Edwardian Ireland (New York: Oxford University Press, 20II), 84-IoI. See also Ita Nessa O'Donovan, 'Music in Irish Periodical Literature, 1770-1970', unpublished $\mathrm{PhD}$ dissertation, University College Dublin, 2013.

I5 See 'The Invention of Irish Music: Remembering Grattan Flood' in Vjera Katalinić and Stanislav Tuksar (eds), Franjo Ksaver Kuhač (I834-I9II). Musical Historiography and Identity (Zagreb: Croatian Musicological Society, 2014), 207-15.

I6 See Barra Boydell, 'Flood, W[illiam] G[rattan]' in Harry White and Barra Boydell (general editors), The Encyclopaedia of Music in Ireland [EMIR] (Dublin: University 
gave short shrift to his dreams of Catholic revival. It is significant that Grattan Flood dedicated his History of Irish Music to Edward Martyn, a fellow-traveller, and friend of George Moore, whose originary impulses as a Celtic modernist were submerged by his enthusiasm for that synthesis of Gaelic-Catholic nationalism which, as it turned out, the new state would later adopt as its cultural ideal, much to the dismay of Yeats and his acolytes. ${ }^{17}$ Martyn loved European music (he endowed the Palestrina choir in Dublin's pro-cathedral), but he cloaked it in Catholic rectitude. Had he been alone in this enterprise, this would scarcely have mattered, but he was not. The moment European music became an expression of reactionary nationalism in Ireland, its creative impulses - already overtaken, as I have argued elsewhere, by literature - were in trouble. It might (and did) survive as an agent or amenity of civilized governance, but it could not rival literature, and still less the 'priceless heritage' of traditional music as a mode of Irish identity.

In these circumstances, the prospects for any kind of Irish musical patrimony other than that of the tradition itself were to remain remote. To adapt an elegance of Paul Collins (writing about music in a very different but related context), Europe was out and 'trad' was in. ${ }^{18}$ The principal reasons for this may by now appear self-evident to me (as to many other people), but it is perhaps useful to summarize them very briefly here. In the first instance,

College Dublin Press, 2013), vol. I, 394-8. Boydell's article includes the most complete bibliography of Grattan Flood's prodigious writings on musical history (Irish and otherwise) to date.

17 In later life, Martyn's theatrical interests were overtaken by his enthusiasm for (and financial generosity towards) church music and his espousal of the music of Wagner. As the dedicatee of Grattan Flood's A History of Irish Music (Dublin: M. H. Gill, 1905), Martyn could not have mistaken the emphatically pro-Catholic stance of Grattan Flood's own reading of Irish musical history.

I8 See Paul Collins, 'Catholic church music in Limerick, c. 1860-1965' in Kerry Houston and Harry White (eds), A Musical Offering. Essays in Honour of Gerard Gillen (Dublin: Four Courts Press, 2018), 9-24, here at 21: 'In short, the chant was in and the ladies were out'. Collins is describing the after-effects of the papal interdiction against women in church choirs included in the papal encyclical motu proprio published by Pius $\mathrm{X}$ in 1903 . 
traditional music by the early 1920s had acquired an idealized condition of meaning (even if much of it remained uncollected and unheard) as a cultural marker of Irish identity. In this respect, it found itself in the front line, as it were, of identity formation, if only because of the recession of Irish itself as a spoken language. Secondly, in a country so decidedly ambivalent about the nature of European music as anything other than a civilized amenity, and one which was indifferent to its organic and narrative modes of behaviour, traditional music (again, as an ideal as well as a sounding form) promoted an identity which might complement the Celtic modernism of the literary revival without rivalling its claims to originality and distinctiveness of voice ('as for the peasant', Yeats once loftily remarked, 'he has his folk songs and his music'). Thirdly, Irish traditional music was 'ready-made' and to hand: its estate had been affirmed for at least a century before independence; its presence was incontestable (one might say essential) to Ireland's claims to cultural autonomy and its perceived purity of discourse, uncontaminated by the 'filthy, modern tide' of urban commerce appealed not only to the avatars of the Catholic-Gaelic constituency of cultural regeneration (which is to say the new state itself) but to a decisive strain of literary modernism (Yeats again, of course) which had no interest in music whatever, except as an unnerving distraction from the serious business of re-imagining Ireland through the agency of English verse and prose. ${ }^{19}$

All of this contributed to the representation of traditional music principally in terms of preservation, and in two senses. One of these senses connoted the obvious meaning of retrieval and recovery; the other connoted safeguard and isolation. The mutation from 'folk music' to 'traditional music' and from 'traditional music' to 'Irish music' entailed both of these meanings and ensured that little else by way of musical discourse could

Many of the points summarized here are more fully argued and disclosed in Mark Fitzgerald and John O'Flynn (eds), Music and Identity in Ireland and Beyond (Farnham, Surrey: Ashgate Publishing, 2014). See especially the essays by Barra Boydell (on Irish music and Anglo-Irish identity in the eighteenth century), Martin Dowling (on traditional music in the Irish Revival), Edmund Hunt (on attempts to instigate a national school of composition in Ireland in the early twentieth century) and the present author (on traditional music as a cultural invention). 
be of equal account. This does not mean that the new state completely washed its hands of music in Europe in pursuit of cultural autonomy: on the contrary, it fostered a small but incremental presence for European music through the agency of sound radio and the patronage of a symphony orchestra, even if it took until 1948 before this latter amounted to something like the real thing. ${ }^{20}$ The debates about music in Ireland raged on in the meantime, and by the early I950s, its sorry condition was apparent to interested parties such as Brian Boydell, who declared in 195 I that 'music in Ireland is in a shocking state'. ${ }^{21}$ Aloys Fleischmann, who edited a survey of the profession in the following year, reached much the same conclusion. ${ }^{22}$

Given the economic stasis and unabated emigration that conspired in strange sympathy with Ireland's grim orthodoxies (religious and otherwise) throughout the first three decades of Independence, it might seem that this conclusion, however widely and disparately understood, did not count for much. The Free State (and later the Republic) certainly had more urgent matters on its mind. But within the folds of cultural formation, and in spite of a fragile but persistent case for European music not as a bourgeois museum culture but as a mode of Irish identity, the emergence (and genius) of Seán Ó Riada decisively resolved this uncertain state of musical affairs.

Ó Riada discovered two things in fairly short order about Irish music, both of which would deeply affect (and indeed shape) its reception history to the present day. One of these discoveries I have long countenanced in my own work, but the other I have resisted until much more recently. Both of them speak directly to the question of musical inheritance or patrimony with which I am concerned here. I think I can render both discoveries in two sentences: (I) Ó Riada found that traditional instrumental music gave him a

20 See Axel Klein, 'RTÉ (Raidió Telefís Éireann)'; Wolfgang Marx, 'RTÉ Concert Orchestra'; Michael Lee, 'RTÉ lyric fm'; Axel Klein, 'RTÉ National Symphony Orchestra' in EMIR, vol. 2, 902-3, 904-5, 905-6 and 907-8 respectively. At the present moment (December 2017), the future of one of the RTÉ orchestras is in doubt.

2I See Brian Boydell, 'The Future of Music in Ireland', The Bell, I6/ 4 (195I), 2I-9, here at 29.

22 See Aloys Fleischmann, Music in Ireland: A Symposium (Cork and Oxford: Basil Blackwell, 1952). 
voice which resolved his own crises as a composer, becalmed as he had been by the shallow backwaters of Irish musical modernism. (2) He also discovered that traditional Irish music is intransitive. I'm going to take a guess that it is the second of these discoveries that requires a gloss here. ${ }^{23}$ 'Irish music is not merely not European', Seán Ó Riada remarked in a series of lectures for radio appositely entitled Our Musical Heritage in 1963, 'it is quite remote from it. It is indeed closer to some forms of Oriental music. The first thing we must do if we are to understand it, is to forget about European music'. ${ }^{24}$ And that was that. Case closed. Irish music might be any number of other things - the serpent with its tail in its mouth (Ó Riada's favourite image), 'Last night's fun' (Ciaran Carson's vigorous shorthand for mildly seditious entertainment), ${ }^{25}$ 'ceol agus craic' (a commodified if bland tribalism meant to connote a similar sensation), a 'Song for Europe' (so that winning the Eurovision Song Contest would eventually become the very definition of a pyrrhic victory) or the recreation of tens of thousands of people in transports of joy at a rock festival (and knee-deep in mud, given the Irish weather).

Ó Riada did not actually declare that Irish traditional music is intransitive (the word is my usage, not his, even if it has taken me over thirty years to come upon it). But what Ó Riada did mean when he made his grand declaration about Irish music not being European amounts to the same thing. Irish instrumental traditional music is too much itself to fold into the narrative syntax and teleology of tonal genres. When it does make an appearance in the symphony, for example (I mean whole and entire, which is very rarely the case), the effect is akin to watching someone in shorts and roller blades skate gracefully and stylishly up the nave of a church during a wedding, at which everyone else is in a solid phalanx of formal dress and high hats. ${ }^{26}$ On more than one occasion in listening to contemporary works

23 My position on Ó Riada is summarized in Harry White, 'Ó Riada, Seán [John Reidy]' in EMIR, vol. 2, 803-6.

24 Seán Ó Riada, Our Musical Heritage (Portlaoise: Dolmen Press, 1982).

25 Ciaran Carson, Last Night's Fun. In and Out of Time with Irish Music (Berkeley, CA: North Point Press, 1996).

26 This effect has a long history, but the phenomenon itself is rare. There are very few Irish symphonies that engage with traditional music, one notable exception being 
which seek to juxtapose traditional music alongside a modernist palette of compositional discourse (as against importing one directly into the other), I have been irresistibly drawn to the impression that the modernist textures sound like an angry orchestral engine of disquiet, charged with dissonance (figuratively as well as literally), whereby the Irish air repossesses the rhetoric of an innocent solitude. ${ }^{27}$ Irish music is intransitive insofar as it resists assimilation. And it only founders upon its own completeness when this is thrown into awkward and implausible relief. It thrives on literal or decorated repetition, which is coterminous with its aesthetic meaning. (In that respect, at least, it betrays its early eighteenth-century incarnation and its formal reliances). What I mean most of all is that the signatures of Irish traditional music are so completely the sound which signifies Ireland, that all other sounds which might amount to the same condition of meaning are almost by definition eclipsed. The implications of this complete alignment between form, voice, identity and meaning are grave indeed when we turn to consider the repertory which the tradition leaves in its wake. And something similar might be said about Irish music as a global signature, as a commodity and as a cultural artefact. ${ }^{28}$

It is not only that Seán Ó Riada himself abandoned composition as a meaningful entity after he had worked his way through the film scores, a handful of orchestral and vocal compositions and a few gestures in the direction of German modernism, and invented the Irish 'folk orchestra' (his term) as an ideal medium for his musical imagination. The unassailable

Stanford's Third (the 'Irish' symphony of I887). Bernard Shaw's characterization of this work as a 'fearful conflict between the Celt and the Professor' cogently expresses the problem identified here.

27 Such occasions are also rare, but a comparatively early work by the composer Deirdre Gribben, Tribe (1997), written in response to the Northern Crisis, is exemplary of this dual condition, as between its dissonant orchestral textures and the redemptive clarity of the traditional air.

28 In a forthcoming paper I have probed the reception of Irish music in Germany as one which is exclusively preoccupied by the signatures of the tradition itself. See Harry White, 'Das Land ohne Musik? Ireland in the European Ear' in Gisela Holfter and Bettina Migge (eds), Ireland in the European Eye (Dublin: Royal Irish Academy, in preparation). 
evidence of reception history, long after Ó Riada's early death (and, it has to be said, the gradual demise of his auditory presence), confirms the traditional ensemble (from Ceoltóirí Chualann to The Chieftains, and far beyond these incarnations to the traditional session itself) and its intransitive condition of discourse as indispensable and resilient markers of Irish musical identity. The astounding musicianship, longevity and stylistic coherence of The Chieftains (since I've mentioned them) attest to this classicizing impulse. They also attest to the concept of Irish musical heritage as a sounding form and as a material repertory. One might even argue that no history of Irish music after 1970 worth the name could afford to overlook this concept. To put this another way: individuality of voice, expressive and technical artistry and the integrity of repertoire in Irish traditional music, do not depend on those concepts of autonomous art and compositional originality, which have governed the European musical work for so long. In the normative sense, the category of 'composer' does not apply when we come to consider the music of The Chieftains. ${ }^{29}$

\section{'Not Wanted on the Voyage'}

But what if it should transpire that this category was essential to a different kind of Irish music which enjoyed virtually no answering echo whatever from the environs of cultural history? What if a hidden history of art music, which bypassed the intransitive condition of traditional music and embraced instead the generic and narrative prowess of European models

This is not to deny the individuality of style as an agency of traditional music. The artistry and sheer imaginative prowess with which a fiddle player like Martin Hayes can imbue the received tradition of a single tune (as in his performance of 'The Sailor's Bonnet' with The Gloaming) posits performance as a deliberated rival to composition and interpretation as a signifier of canonic import (particularly in relation to Irish art music). Nevertheless, the intransitive condition of the pre-existent air remains in all such cases an indispensable feature of the performance itself. 
of musical discourse, should disclose an almost completely unrelated patrimony, deracinated in the annals of Irish reception history to the point of inaudibility? The conditional mood of such questions is conveniently resolved by The Invisible Art: A Century of Music in Ireland, IgI6-2oI6, which originally accompanied a three-week concert series (entitled 'Composing the Island') curated by the National Concert Hall and RTÉ in September 2016. Both the concert series and the book itself represented a rather astonishing phenomenon, namely an entire century of Irish music largely unrelated to the traditional repertoire. It was unsettling and satisfying at once to witness my own reading of music in Irish cultural history pass so easily (after years of considerable dissent) into a wider domain, a reading signified not least by the title of the book itself (The Invisible Art is clearly intended for a general readership). I had nothing to do with either the book or the sequence of concerts which initially accompanied its publication (even if I was very curious to see how both would turn out). ${ }^{30}$ It's true that my own work is generously represented in The Invisible Art (which was another agreeable discovery), and that the book includes within its purview a very well-disposed account of the development of musicology in Ireland, specifically as this relates to Irish art music. ${ }^{31}$

But as a detailed vademecum to Irish art music over the past century (and a very handsomely illustrated one at that), The Invisible Art perhaps inevitably asks more questions than it answers. It is rich in reportage, information and argument, but it does not and cannot pretend to explain the even more astonishing disconnect between the music it surveys and the norms of Irish cultural reception. I have just observed (above) that one could not imagine a history of Irish music since 1970 which did not privilege The Chieftains. Their absence from The Invisible Art nevertheless graphically illustrates the provisional difficulty of this argument, to say little of the void that has separated European musical practice from Irish cultural history

30 I reviewed The Invisible Art for The Irish Times in December 2016. See <https:// www.irishtimes.com/culture/books/the-invisible-art-review-a-mosaic-of-musicbrought-to-light $>$. [Accessed 29 December 2017].

3I See in particular Martin Adams' essay in The Invisible Art, 'History in the writing', 198-216. 
almost as a matter of principle. It is this void in which the question of an unwanted or circumvented musical patrimony is located.

The most succinct means of illustrating this problem is to glance at either end of the spectrum surveyed by The Invisible Art and 'Composing the Island', both of which (effectively) begin and end respectively with the Irish composers Charles Villiers Stanford (1852-1924) and Gerald Barry (1952-).

Stanford first: even now we are entitled to ask questions about what it might mean to regard Stanford in any fundamental sense (other than the circumstances of his birth and upbringing) as an Irish composer. There is copious evidence in the music itself to support Stanford's Irishness, but there is correspondingly almost no comparable cognizance of this in the annals of Irish cultural reception history. ${ }^{32}$ Most of his music - it includes six Irish orchestral rhapsodies, twelve operas (at least two of which are explicitly Irish in origin or subject-matter), seven symphonies, two piano concertos, a setting of the Roman Catholic Requiem (the first by a British or Irish composer), a host of oratorios, vocal settings and chamber works has never been heard in this country. The English composer Arnold Bax remarked in 1952 that 'Stanford never came a thousand miles within reach of the hidden Ireland', a characteristic dismissal all the more injurious on account of Bax's own enchantment with Irish poetry (Yeats above all), from which Bax's early tone poems were derived. ${ }^{33} \mathrm{With}$ the sovereign exception of his Anglican Church music, which has remained in circulation ever since it was first written, Stanford's musical estate has largely remained offshore. Even in Britain, it was only within the past thirty years that a serious scholarly address combined with a renewal of interest in the orchestral music especially, restored the composer to a modest place in British concert life. Until then, Stanford's achievements - as a teacher and conductor as well as a composer - in leading the renaissance of British music alongside Hubert Parry had been decisively remaindered by Elgar

32 An important exception is Liam Mac Cóil, An Chláirseach agus an Choróin (Galway: Leabhar Breac, 2010). The definitive study of the composer is Jeremy Dibble, Charles Villiers Stanford. Man and Musician (New York: Oxford University Press, 2002).

33 Bax made this comment in his foreword to Fleischmann's Music in Ireland (as note 22 above). 
and those British composers who followed in his wake. One of the principal architects of this occlusion was none other than Bernard Shaw, who derided British music in general and Stanford in particular as a matter of course during his galley years as an influential music critic, a remorselessly negative campaign which did not cease until Shaw had established himself as a dramatist. (It was in the aftermath of this success that Shaw championed Elgar and changed his mind about the future of English music). ${ }^{34}$ This turnaround, however, was too late for Stanford himself. But even if we were somehow to revive Stanford's explicitly Irish music (I mean here in Ireland), such an enterprise would sooner or later stumble upon the irrelevance of Stanford's compositional metier not only to the reception history I have sketched in this chapter, but also to the verbal matrix of the Celtic and Gaelic revivals alike. Operas, string quartets and symphonies were (and remain) generic models of musical discourse aloof from the cultural (and ultimately political) regeneration of ideas which distinguished Ireland's claims to autonomy in the first place.

At the other end of the century, we encounter Gerald Barry, an enfant terrible in his mid-sixties whose success on the London stage and more general prominence on the international operatic and concert platforms certainly registers in Irish journalistic commentary (and to a limited extent in Irish musicology), so that if Barry's music belongs to an 'invisible art', this can only be in Irish terms. It's an audacious enterprise to liken almost any contemporary art music to the kind of reception which contemporary literature enjoys, but just consider for a rhetorical moment a likening between Gerald Barry and Sebastian Barry (the novelist is three years the composer's junior). The public themes engaged by Sebastian Barry's fiction and drama are demonstrably and immediately of account to recent Irish political and social history (the Great War, the northern crisis, social exclusion and incarceration), whereas Gerald Barry's themes are meditations,

34 See Dan H. Laurence (ed.), Shaw's Music. The complete musical criticism in three volumes (London: the Bodley Head, I98I). In I888, Shaw advised readers of the Pall Mall Gazette that Stanford's recently composed Irish Symphony represented 'an additional proof that the symphony, as a musical form, is stone dead'. See Shaw's Music, vol. I, 515. 
often idiosyncratic and highly individualized in temperament, on European literary modernism and its antecedents (Fassbender, Strindberg, Lewis Carroll). ${ }^{35}$ His music is Irish at one remove, which is not to deny his claim to our attention (far from it), but to contextualize this claim by locating it within the international domain of idiolects that comprise western art music in the late twentieth and early twenty-first centuries. Even his most ostensibly Irish work, an opera based on Wilde's The Importance of Being Earnest (2010) brilliantly subverts the genre to which it belongs, so that the deliberately strident parodies of opera buffa (in which Barry's opera is laughing and sometimes screaming at itself) call the verisimilitude (not to say legitimacy) of the genre into question. First and foremost, perhaps, Barry writes music which is about music. And however far removed in time and temperament he may be from Stanford, his strongly European inclinations, his assiduous cultivation (one might say retention) of the composer as an individual entity and his stringent protection of the autonomous musical work bring him close to his distant (and no less operatically inclined) forebear. However, his music too, for the most part, lies offshore. ${ }^{36}$

It might be facile to suggest that the more completely an Irish composer is invested in the discourse of European modernism (or European romanticism, for that matter), the less likely it is that she or he will receive a sustained or broad listenership in Ireland, but it is difficult to avoid such a conclusion nevertheless. If I am even half-right about this, it follows that the patrimony that silently entails upon Irish music is hardly even that. A heritage which lies in abeyance or which affirms its remoteness from the

As in the operas The Bitter Tears of Petra von Kant (2005) based on the play (and later film) by Fassbender; La Plus Forte (2007) based on the play by Strindberg and Alice's Adventures Underground (2015), after the 'Alice' novels of Lewis Carroll. For a survey and discussion of Barry's compositional technique and development see Mark Fitzgerald, 'Barry, Gerald' in EMIR, vol. I, 59-63.

36 Stanford and Barry are two Irish composers born exactly a century apart whose works nevertheless affirm the imperative of exile (literally and figuratively) from the domain of Irish cultural affairs. The revival of interest in Stanford's music (largely through the agency of recordings of his symphonies and chamber music) in the 1990 and the success enjoyed by Barry's operas in the past fifteen years belong to (and depend upon) the vitality and enterprise of British musical culture. 
general interest is hardly a heritage at all. It's not wanted on the voyage, to borrow a phrase.

Why not? That phrase, Not Wanted on the Voyage, is the title of a novel published in 1984 by the Canadian writer Timothy Findley, whose work I do not know, although it was widely in circulation when I was a student in Toronto in the early I980s. (As in Ireland, there were so many very good writers to choose from.) It suits my purposes here because in bringing this chapter to a close, I'd like to revisit some research I conducted a few years ago on the reception history of Irish music in relation to that of Canadian music, and of French-Canadian musical culture in Quebec in particular. My research rested on two principal comparisons, between The Encyclopaedia of Music in Ireland (2013) (EMIR) and the revised edition of the Encyclopedia of Music in Canada (1992) (EMC), on which the Irish publication was expressly modelled; and on the representation of music in Dublin and in Montreal respectively in those publications. ${ }^{37} \mathrm{I}$ took as my point of departure an essay by the Canadian musicologist Robin Elliott which appeared in 2010 , in the course of which Elliott remarked that 'whatever the claims on the Canadian soul of the far North in particular, or landscape in general, the fact remains that music, as a reifier of Canadian identity, barely registers on the pulse of the national heartbeat. ${ }^{38}$ This sounded a familiar note to me, not of course in relation to Irish traditional music (is there any musical tradition which more exactly registers the country from which it derives?), but in relation to that doubtful patrimony which I have been discussing in this chapter. Time does not permit me to explore the first of these comparisons here (between EMIR and EMC), except to remark that both publications privileged musical practice over the musical artwork to good end, a preference otherwise extremely unusual in musical lexica. This was because in both cases it proved more productive to survey varieties of

37 See Harry White, 'Courtyards in Delft' in Margaret Kelleher and Michael Kenneally (eds), Ireland and Quebec. Multidisciplinary Perspectives on History, Culture and Society (Dublin: Four Courts Press, 2016), 197-210.

38 See Robin Elliott, 'Canadian Music: a View from Dublin' in Ivano Cavallini and Harry White (eds), Musicologie sans Frontieres: Essays in Honour of Stanislav Tuksar (Zagreb: Croatian Musicological Society, 2010), 377-86; here, 384. 
musical discourse as ends in themselves, as staging posts in the topography of Canadian or Irish musical experience, rather than limit research to the authority of the autonomous artwork, or the biography of Irish and Canadian composers. 'The music historian focuses first on works of music, whatever else he might survey', the American musicologist Gary Tomlinson pronounced in $1987 .{ }^{39}$

All I can add here is that Canadian and Irish lexicographers of music have done otherwise, because to resolve the music of either country under the aegis of autonomous art or 'musical works' would have resulted in a drastic reduction in vision. It turns out that in Canada, as in Ireland, 'works of music' (at least in the sense conveyed by generic autonomy or literary prototypes), comprise a significantly smaller proportion of musical life than we might suppose. The only begetter of contemporary musical lexicography, The New Grove Dictionary of Music and Musicians (1980), for all its Promethean engagement with the music of the world's peoples, nevertheless prioritized the musical work (the art work, the easiest point of connection between musical genres and literary genres), when it came to music in Europe. The plurality of musical practices surveyed in EMIR did (I think) produce a topography, a kind of ordinance survey of Irish musical experience across a very wide span of time, but this did not amount to a narrative history or any other similar resolution of that experience. The same was true (I also think) of its Canadian precursor. In these musical landscapes, 'heritage' was much less a canon of artworks, winnowed and sifted from the general chaff, and much more a record of music as an agent of political, religious, cultural and social experience.

The second comparison I essayed in my research - between music in Dublin and music in Montreal - produced very different results. Although the headwords in both publications beginning with 'Montreal' and 'Dublin' respectively are uncannily similar (both clusters reveal an almost identical reliance on musical institutions ranged along a colonial and postcolonial perspective which draws musical culture in Quebec and Ireland into close

39 See Gary Tomlinson, Monteverdi and the End of the Renaissance (Berkeley, CA: University of California Press, 1987), ix. 
proximity), ${ }^{40}$ the comparison breaks down when it comes to orchestral music in both cities. This is because my Irish exemplar - the RTÉ National Symphony Orchestra - has (of necessity, I would suggest), devoted its energies to squaring the circle that surrounds the European musical estate and its own (wavering) obligations to Irish musical art, whereas my FrenchCanadian exemplar - the Montreal Symphony Orchestra - has forged a distinctive identity over the past forty years as one of the pre-eminent curators of the French orchestral repertoire. Its energies are devoted almost whole and entire (certainly insofar as its stellar recordings and international tours are concerned) to French music. Its attention to French-Canadian music, by comparison, is minimal. This represents one solution to musical patrimony in a postcolonial world, but I doubt very much if a similar determination would find favour in Ireland. ${ }^{41}$

In 20I4, RTÉ embarked on a 'national quest' to find Ireland's favourite poem. ${ }^{42}$ The result (announced in March 20I5) was Seamus Heaney's 'When all the others were away at Mass', from 'Clearances', a sonnet sequence dedicated to the memory of the poet's mother and first published (in a limited edition) in 1986. Whatever its other virtues (endangered, perhaps through constant repetition and exposure), one compelling feature of that poem is its conjunction of formal and technical reliances that are assuredly Elizabethan (the trim composure and structural governance of the sonnet), with an inflection of tone and delicate authority enabled by Heaney's own vision and voice. That voice - literally in this instance - proves to be national and intimate at one and the same time. The intimacy between the artist's sensibility, his formal jurisdictions and a hair-fine antenna which both receives and transmits the 'national heartbeat' (Elliott) is resolved

40 As in 'Dublin Baroque Players', 'Dublin College of Music', 'Dublin Festival of Twentieth Century Music', 'Dublin Grand Opera Society', 'Montreal Bach Choir', Montreal Consort of Ancient Music', 'Montreal International Music Competition', 'Montreal Opera Company', and so on.

4I See White, 'Courtyards in Delft' (206-8) for further details of this comparison and for an analysis of the French orchestral repertory which the Montreal Symphony Orchestra has so strikingly cultivated.

42 For details, see <https://apoemforIreland.ie >. [Accessed 30 December 2017]. 
through the self-standing agency of a work of art. It is this resolution that produces not a reluctant or hard-won (or invisible) patrimony, but a new site in the human soul. We resolve our literary heritage through the agency of individual works. Irish musical practice over the past century has not sought (or has not achieved) that kind of miraculous autonomy, that intimate communion between tradition and the individual talent which allows a canon of musical works to arise and to develop. The contrast between Ireland's assiduous cultivation and circulation of European literary genres and her disavowal nevertheless of European musical genres throws the question of musical patrimony into sharp relief. Our symphonies remain silent. ${ }^{43}$ This, too, is an inheritance, and it deserves to be countenanced.

43 Except, of course, when such musical terms are (significantly) extended to Irish writing. 'The music of Jamie O'Neill's prose creates a new Irish symphony', Peter Ackroyd wrote of O'Neill's At Swim, Two Boys (200I), a remark that apostrophizes the vibrant afterlife of European musical genres in Irish fiction. See <https://www.amazon.com/ Swim-Two-Boys-Jamie-ONeill/dp/0743207149>. [Accessed 30 December 2017]. 
PART II

Tourism and Culture 



\section{4 'Protestant Strangers and Others': Re-imagining the Contribution of French Huguenots and their Descendants to Ireland's Ancient 'Patrimoine'}

Coined by François Puthod de Maisonrouge in 1790, the term 'patrimoine' proposed that 'acquired property, works of art, scientific discoveries, literature, and local dialects be preserved as memorials of French history, rather than discarded as the unwanted artefacts of an ancient order'. Of more significance, however, was his desire to invigorate an all-encompassing awareness of the 'other', whereby the transformation of 'patrimoine familial' to 'patrimoine national', while preserving identity, would simultaneously act to foster a broader inclusivity. ${ }^{1}$ Interestingly, in addressing the annual commemoration service for Huguenots at Dublin's St Patrick's Cathedral in 200I, Canon William Neely of Keady, Co. Armagh, appeared to echo similar sentiments, when opining that, 'Romantic Nationalism has been the blight, indeed the curse of our people', and adding, 'we must all learn to take pride in, and cherish, our alternate heritage'.

However, one might historically argue that such 'accommodation' is not that straightforward, in that what might euphemistically be deemed 'alternate' heritage, has, to varying extents, been airbrushed from Ireland's collective memory, depending on the degree to which its 'appropriateness' has been determined within the commemorative imperatives of families, religious orders and educators. For example, by the time Ireland secured her political freedom in 1922, the Catholic population had risen to 95 per cent, resulting in an overwhelming desire for Catholic-led education among

I Marilena Vecco, 'A Definition of Cultural Heritage: From the Tangible to the Intangible', Journal of Cultural Heritage (2010), Vol. II, Issue 3, 326. 
a recently emboldened Catholic majority. ${ }^{3}$ Synchronizing with this potent mix of nationalistic and ecclesiastical fervour, a cohort of religious communities flourished whereby what was considered the unpalatable heritage of a once dominant Protestant elite, was overtly suppressed, while the newly validated constituency of a nationalistic heritage, which emphasized Catholic identity, Gaelic games, the Irish language, and stories of Ireland's fight for freedom, was foregrounded.

However, while such protectionist expediencies were not uncommon in what was a politically evolving Europe during the seventeenth and eighteenth centuries, where the rallying of citizens to the flag, the preservation of the bourgeoisie, or the protection of a threatened ruling class, determined nationalistic responses in France, Germany and England, ${ }^{4}$ in today's more enlightened times, the re-imagining of heritage is more often expressed by way of encouraging civic engagement with heritage-related activities, evidenced in the popularity of local festivals, wherein the fortuitous presence of a rediscovered 'history' offers opportunity for celebration. ${ }^{5}$ Indeed, the re-imagining of long neglected or forgotten heritage often entices a society to see the 'extraordinary' in what might once have been considered 'ancient', 'ordinary', or of 'negligible value'.

In recent years, for example, tourism promoters in Dublin have afforded a new legitimacy to an ancient 'patrimone', by categorizing the heritage of Viking invaders who plundered and pillaged Ireland, as a visitor attraction, resulting in the area between Christchurch Cathedral and the River Liffey being renamed 'The Viking Quarter', which begs the question as to whether a similarly 'alternate' heritage might also be traceable among migrant populations, seduced by the lure of opportunity, or coercively

3 Deirdre Raftery, 'The "Mission” of Nuns in Female Education in Ireland, c. 1850-1950', Paedagogica Historica (2012), Vol. 48, No. 2, 302. Astrid Swenson, The Rise of Heritage: Preserving the Past in France, Germany and England 1789-1914 (Cambridge: Cambridge University Press, 2013), 31-40. Cf. Tony Kiely, 'From Tullycross to La Rochelle: Festival Food, French Connections, and Relational Tourism Potential', in F. Healy and B. Bastiat (eds), Voyages between France and Ireland, Culture, Tourism and Sport (Oxford: Peter Lang, 2017), 215-35.

6 Stephen Royle, 'Exploitation and Celebration of the Heritage of the Irish Islands', Irish Geography (2003), Vol. 36, No. I, 28. 
relocated into unfamiliar liminal spaces, who may have unwittingly printed their 'patrimoine' on what became their new home? One wonders, therefore, if equivalent transformative influences could be attributable to the arrival on Ireland's shores of a migrant community of Huguenot refugees over three centuries ago, bringing with them a significant array of military, artisan, topographical, architectural, engineering, educational and philanthropic skills?

Derived from the French 'réfugiê', the connotation 'refugee' was employed in the seventeenth century to illustrate the sense of desperation that forced approximately 200,000 Huguenots to seek refuge outside of their native France, with up to I0,000 of these coming to Ireland. ${ }^{7}$ Huguenots were French Protestants, who though aligning with Martin Luther's Reformation thesis of 'Sola Scriptura', which, while emphasizing the pre-imminence of Scripture, railed against endemic corruption within the Catholic Church in Europe and embraced the more austere, non-conformist maxims of French theologian John Calvin (I509-64). However, despite their unswerving commitment to such deeply ethical practice, their typecasting as 'Huguenots' was pejoratively employed to convey an image of oddness or eccentricity to their religious and secular behaviour. ${ }^{8}$ Nonetheless, despite such prejudicial typecasting, their population dramatically increased, in what was then a predominantly Catholic France where, in addition to their notable business acumen and networking skills, they increasingly accessed senior positions at the Royal Court, a practice which created much unease amongst the whispering Catholic classes, particularly when such access became the norm rather than the exception. ${ }^{\text {? }}$

The consequential upsurge of fear and loathing among the Catholic population resulted in the persecution and displacement of Huguenot communities, evidenced in the slaughter of up to I0०,००० of their members

7 Robert Hylton, Ireland's Huguenots and their Refuge I662-1745: An Unlikely Haven (London: Sussex Academic Press, 2005), 81.

8 Robin Gwynn, Huguenot Heritage: The History and Contribution of the Huguenots in Britain (London: Routledge and Kegan, 1985), 2.

9

Gwynn, Huguenot Heritage, 40. 
during the infamous St Bartholomew's Massacre on 24 August 1572, and the sacking of La Rochelle, the Huguenot capital of France, in 1628 . The most serious blow, however, was delivered on 22 October 1685 , when King Louis XIV (The Sun King), signed The Edict of Fontainebleau (more popularly known as The Revocation of The Edict of Nantes), which forbade all Protestant services, stipulated that their temples be destroyed, and that women and children be incarcerated in convents, where they would be forcibly baptized into the Catholic Faith. Accordingly, faced with the unbearable prospect of becoming Roman Catholic, many chose to become exiles and, at enormous risk to their lives, fled from France.

\section{Migration and Re-settlement}

Following the Revocation of The Edict of Nantes, many Huguenots moved to safe Protestant lands in Holland, Switzerland, England, Germany and Sweden, whose existing Calvinist communities guaranteed them the freedom to practise their non-conformist religion. ${ }^{10}$ Moreover, for those in possession of much needed military skills, their subsequent passage from Holland to Ireland, where the Dutch King, William of Orange, was actively involved in suppressing a Catholic rebellion, also made perfect sense, in that they believed, if successful, he might then turn his attention to subjugating King Louis, thus accelerating their long held wish to return to their beloved France. ${ }^{11}$ Interestingly, while this migrational exodus was both culturally and materially debilitating for France, which lost many skilled craftsmen and military personnel, it was a bonanza for William, whose army at Ireland's historically defining Battle of the Boyne, was emboldened by

Io Ruth Whelan, 'The Huguenots and the Imaginative Geography of Ireland: A Planned Immigration Scheme in the I680s', Irish Historical Studies (2007), Vol. 35, No. I 40, 478 .

II Vivien Costello, 'Researching Huguenot Settlers in Ireland', The BYU Family Historian (2007), Vol. 6, Issue, I, 86. 
several hundred Huguenot officers, and up to four regiments of Huguenot foot soldiers. ${ }^{12}$

For non-military migrants, however, Ireland was a different proposition, in that it was rumoured to have regularly engaged in the slaughter of Protestants, an experience that had expedited their flight from France in the first place. ${ }^{13}$ Nonetheless, the availability of a nomadic mass of displaced Huguenots, possessing small amounts of capital, and considerable skills that were in short supply, was deemed a God-given opportunity to bring some prosperity to what was an economically desolate country. ${ }^{14}$ Accordingly, in what might well be considered 'state-sponsored immigration', the critical factor inducing non-military migrants to come to what for them was an unlikely haven, lay in the ingenious introduction of 'The Act for Encouraging Protestant Strangers and Others to Inhabit and Plant in the Kingdom of Ireland' by the Duke of Ormonde, which facilitated their active recruitment by promoting agents who would subsequently assist with the practicalities of re-settlement. ${ }^{15}$ Illustrating its operational anatomy, an imaginative strategy was 'cleverly employed to project a geographic fantasy onto the complex reality of i7th century Ireland', which biblically depicted the country as 'a land flowing with milk and honey' with a 'temperate climate', wherein religious freedom was 'guaranteed'. Additionally, in promoting its utilitarian opportunities, Huguenots were assured that they would 'not be taxed on their income for up to seven years', and would be made 'Freemen of any town in which they settled'. ${ }^{16}$

As a result of these inducements, Huguenot communities settled in Cork, Carlow, Kilkenny, Wexford, Waterford, Clonmel, Carrick-on-Suir, Youghal, Castleblaney, Lisburn and Portarlington, each of which exhibit

I2 Harman Murtagh, 'Huguenot Involvement in the Irish Jacobite War I689-9I', in C. E. J. Caldicott, H. Gough, and J. P. Pittion (eds), The Huguenots and Ireland: Anatomy of an Emigration (Dublin: The Glendale Press, 1987), 225.

I3 Robin Gwynn, 'Government Policy towards Huguenot Immigration and Settlement in England and Ireland', The Huguenots and Ireland, 214.

I4 Randolf Vigne, 'Le Project d'Irlande: Huguenot Migration in the I690s', Early Modern History Social Perspectives (1994), Vol. 2, Issue. 2, 6.

Is Whelan, 'The Huguenots and the Imaginative Geography of Ireland', 48I.

I6 Whelan, 'The Huguenots and the Imaginative Geography of Ireland', 484-90. 
interesting vestiges of their Huguenot-inflected 'patrimoine'. Indeed, after the Battle of the Boyne, Portarlington was considered the most significant Huguenot town in Ireland, following its gifting to pensioned-off Huguenot soldiers, who were deemed to have won the battle for William. ${ }^{17}$ By 1702, many of those settled became involved in a new and highly successful woollen industry, whose quality exports were subsequently banned by the English Parliament in order to protect their own home industries, resulting in Jonathan Swift's savage indignation at this cruel blow to Ireland's prosperity. Interestingly, from a heritage perspective, Portarlington became exclusively French-speaking for many years, with French etiquette being taught in sixteen separate classical schools, and religious services administered through French in the specially built French church, which exists to the present day, replete with an intact register of Huguenot births, marriages and deaths from 1694 to $1816 .{ }^{18}$

In Dublin, Huguenot immigrants were welcomed to what was a predominantly Protestant city, settling near St Patrick's Cathedral, in an area known as 'The Liberties', where they were afforded the use of the cathedral's 'Lady Chapel', a gesture recorded on the cathedral's north transept bell, which proclaims 'the coming of the Huguenots from La Rochelle in 1685'. Mirroring their business acumen in France, they swiftly established themselves as artisans of silver and gold, weavers of silk, poplin and linen, bookbinders, brewers, sugar bakers, cobblers, hatters, gunsmiths, gardeners and cartographers. Furthermore, from an administrative perspective, they became pivotal members of the Wide Streets Commission, which delivered much of the city's street-scape as we know it today.

From a societal perspective, their self-contained communities produced several distinguished medical practitioners, including James Fontaine (Fountaine), who was appointed Surgeon-General in Ireland in $166 \mathrm{I}$ and John Charles Fleury, who established the systematic teaching of midwifery in Dublin in 1750 . Samuel Bell Labatt became the leading figure in promoting

17 and Co., 1936), I7-18.

I8 Robert Hylton, 'The Huguenot Settlement at Portarlington, I692-177I', The Huguenots and Ireland: Anatomy of an Emigration, 297-302; Lee, I34. 
the introduction of vaccination to Ireland, while Francis l'Estrange, an eminent obstetrician, acted as accoucher at the birth of the poet Thomas Moore in Aungier Street on 28 May 1779. Furthermore, Elias Bouhéreau, a medically qualified émigré from La Rochelle, was appointed first librarian of the world famous Marsh's Library, an architectural gem adjacent to St Patrick's Cathedral, which remains Ireland's first and oldest book lending institution. ${ }^{19}$

\section{Contributions to Artisan Heritage}

At the height of the Huguenot migration, Dublin emerged as one of the major social centres in the English-speaking world, whose high spending landed elite created a rapidly expanding demand for luxury commodities, ably serviced by indigenous communities of Huguenot émigrés in Dublin's 'Liberties'. ${ }^{20}$ Indeed, many of the area's place-names, such as Spitalfields, The Tenters, Weavers Square, Mill Street, Golden Lane, Fumbally Lane and Black Pitts, whisper testimony to their past artisan skills, as noted above. ${ }^{21}$ Deemed an emblem of taste and prestige, Huguenots played a pivotal role in the industrial development of silk manufacturing in the city, evidenced in a sevenfold increase in the importation of raw and thrown silk into Dublin between 1690 and 1720 . Indeed, so protective were they of their craft, they are reputed to have destroyed reams of imported French and Chinese silk during the Dublin cloth riots of $1763 .{ }^{22}$

I9 Charles A. Cameron, History of The Royal College of Surgeons in Ireland, and of The Irish Schools of Medicine, including a Medical Bibliography and a Medical Biography (Dublin: Fannin \& Company, Second Edition Revised and Enlarged, 1916), 384.

20 David Dickson, 'Huguenots in the Urban Economy of Eighteenth Century Dublin and Cork', The Huguenots and Ireland: Anatomy of an Emigration, $32 \mathrm{I}$.

2I Neal Doherty, The Complete Guide to the Streets of Dublin City (Dublin: Orpen Press, 2016), 14I-9.

22 Mairead Dunlevy, Pomp and Poverty: A History of Silk in Ireland (London/New Haven, CT: Yale University Press, 2015), 74. 
In an innovative offshoot of silk-weaving in 'The Liberties', the wellknown Huguenot families of La Touche and Lunel were responsible for the invention of poplin, a unique mix of silk and wool (whose naming was ironically derived from the French 'pape-lin' or 'pope's linen'), ${ }^{23}$ the wearing of which was considered 'de rigueur' in the Royal Courts of Europe for much of the eighteenth and nineteenth centuries. ${ }^{24}$ Consequently, by the early 1700s, such was the volume and output of Huguenot silk and linen weavers, who had gravitated towards the aptly named Mill Street, so called because of its large number of operating mills fed by Dublin's River Poddle, that a substantial 'Weavers Hall' had to be built in the nearby 'Coombe' by Huguenot David Digges La Touche, after whom the nearby Digges Lane is named. ${ }^{25}$

Adjacent to The Coombe is 'The Tenters', an area where Huguenot linen weavers employed linear rows of tenter poles to dye, clean and stretch freshly woven linen. These original tenter lines are clearly visible on John Rocque's wonderfully preserved cartouche, dating from 1756. Rocque, himself a Huguenot, and arguably the finest mapmaker of his time, was so highly regarded, that his magnificently detailed representation of linen weaving in 'The Liberties' was chosen to represent Ireland's cultural heritage on the 1978 issue of the Irish $£$ Io note. Interestingly, Huguenot representations of King William's success were also used to political effect where, in what was once The House of Lords (now the Bank of Ireland on Dublin's College Green), a large linen tapestry entitled 'The Glorious Battle of the Boyne', still hangs in the main visitor hall, depicting William of Orange rearing his steed in a provocative inducement of his troops, many of whom were Huguenot émigrés, to crush the Catholic King James. ${ }^{26}$

Huguenot merchant families were also key to the valuable importation of exotic goods such as wine, brandy, walnuts, prunes and salt, due in the main to their well-networked relationships with regions surrounding

\footnotetext{
23 Dunlevy, 226.

24 Dunlevy, I07-8; 129-3I.

25 Doherty, 142.

26 Pat Liddy, Dublin, A Celebration: From the Ist to the 2Ist Century (Dublin: Dublin Corporation, 2000), $\mathrm{I} 63$.
} 
their native La Rochelle and Bordeaux. ${ }^{27}$ Indeed, tangible evidence of this heritage is still visible on Dublin's Custom House Quay, where Huguenot merchants once owned and controlled a private dock. Correspondingly, Dublin's 'Liberties' became home to a number of Huguenot-owned breweries, distilleries, and over twelve sugar refineries, which serviced a significant sugar baking industry in the area. ${ }^{28}$ Interestingly, one of the major brewers in Dublin at that time was Paul Espinasse, whose family came to Dublin from Languedoc in 1689 , and whose main brewery, prior to his untimely death in a riding accident, stood on the site of the Guinness Brewery at James's Gate, ${ }^{29}$ which is now the city's premier visitor attraction.

During the seventeenth and eighteenth centuries, Huguenot silver and goldsmiths also became the darlings of polite Dublin society, evidenced in the ubiquity of delicate sets of silver casters, such as those designed by David King, and exquisitely embellished by an unidentified Huguenot craftsman known as 'The Stencil Master', which were used for the sprinkling of sugar and seasoning in the finer houses of the city. ${ }^{30}$ Furthermore, though somewhat ironically, many of the ciboria and chalices used by both Catholic and Protestant clergy at that time are said to have been crafted by Huguenot gold and silversmiths, such was the esteem in which they were held. Indeed, a tangible recognition of their skill and attention to detail is evidenced in how the Huguenot Le Bas family held the prestigious post of 'assay master' at Dublin Castle in an unbroken line of service from 1776 to 2016, while D'Olier Street, one of the city's major arteries, is named after Jeremiah D'Olier (1745-1817), a noted Huguenot goldsmith and jeweller, who designed the magnificent Chain of Office, still worn by Dublin's Lords Mayor. ${ }^{31}$

Louis Cullen, 'The Huguenots from the Perspective of the Merchant Networks of Western Europe (1680-1790): The Example of the Brandy Trade', The Huguenots and Ireland: Anatomy of an Emigration, $\mathrm{I} 30$.

Paul Rambaut, 'The Participation of Huguenot Settlers in Dublin's Sugar Bakeries in the i8th century', Huguenot Society of Great Britain and Ireland Proceedings (1993), Vol. 25, No. 5, 487-93. Hylton, Ireland's Huguenots and their Refuge, 123. Ida Delamer and Conor O’Brien, soo Years of Irish Silver (Bray: Wordwell, 2005), 4I. Liddy, 162. 


\section{Topographical Representations of Ireland}

During the eighteenth and nineteenth centuries, a resurgence of interest among European artists in recording and romanticizing local 'patrimoine', was revealed in their romantic fascination with archaeology, folk culture, language, and regional costume. ${ }^{32}$ Indeed, Ireland was no exception to such populist endearment, which resulted in topographical artists being dispatched to depict the nation's ancient 'patrimoine'. Accordingly, much of what we know today about the antiquities of Ireland, its landscape and social behaviours, particularly in the hitherto most inaccessible and unlikely of places, is attributable to two artists of direct Huguenot descent, namely, Gabriel Beranger (1729-1817), and George Victor Du Noyer (1817-69). Born to French Huguenot parents in Rotterdam, Beranger arrived in Dublin at the age of twenty-one, and quickly secured a reputation for his precise drawings of the city's remarkable buildings, ranging from the austere geography of the Huguenot owned lead mines in Dolphin's Barn and the Protestant Archbishop of Dublin's summer residence in Tallaght, to the Round Tower of St Michael le Pole (which stood at the entrance to Dublin Castle), all of which have long since disappeared..$^{33}$

A noted and fearless traveller, Beranger's first antiquarian tour in 1773 focused on Wicklow, where he executed precise representations of the seven churches of Glendalough, and the surrounding monastic environment. Furthermore, in 1779, accompanied by Italian painter, Angelo Maria Bigari, he embarked on a seventy day expedition covering the western half of Ireland, which, in producing the most comprehensive archaeological survey of that region prior to the arrival of the Ordinance Survey of the I830s, poignantly captured significant representations of over 200 medieval

32 Julian Campbell, 'The Representation of Everyday Life in Irish Painting of the igth Century: The European Context', in Peter Murray (ed.), Whipping the Herring: Survival and Celebration in Nineteenth Century Irish Art (Cork: Crawford Art Gallery, 2006), 25-6.

33 Peter Harbison, Gabriel Beranger: Drawings of the Principal Antique Buildings of Ireland (Dublin: Four Courts Press, 1998), 28, 32. 
settlements and castles, such as Boyle Abbey in Roscommon, Knockgraffon in Tipperary (the precursor of the of the modern towns of Cahir and Cashel), and Claddagh Castle in Galway, whose original splendour could only be imagined, were it not for their endeavours. ${ }^{34}$

Accentuating the significance of such expeditions, Sir William Wilde, the noted Dublin opthalmic surgeon and father of Oscar Wilde, argued that their invaluable contribution captured for posterity Ireland's cahirs, cromlechs, cloughrans and prehistoric monuments a decade before the French Revolution. ${ }^{35}$ Nonetheless, Beranger would have remained largely anonymous to those outside the archaeological world were it not for the endeavours of the aforementioned Sir William Wilde and his wife 'Speranza' who, in securing his diaries after his death, championed his drawings in their Memoir of Gabriel Beranger. Intriguingly, the diaries also reveal that Beranger was a particularly close observer of the language patterns, customs, dress and behaviour of the people he met while travelling. For example, his account of a sketching tour in Wexford in 1780 documents the health conditions, language patterns, and social demeanour that characterized the local people at a particular point in history, making them, from a 'patrimoinal' perspective, of significant interest both to social historians and the general public alike. ${ }^{36}$

Considered an even more gifted topographer, geologist and antiquarian George Victor Du Noyer spent much of his life painstakingly recording the botanical, paleontological and zoological antiquities of Ireland, both as a draughtsman on the inaugural Ordinance Survey of the country (1835-42), and later, while employed on The Great Victorian Geological Survey of Ireland (1845-47), where his endeavours showcased Ireland's hidden beauty and contemporaneous social history both during and after The Great Famine. ${ }^{37}$

34 Peter Harbison, Beranger's Views of Ireland (Dublin: Royal Irish Academy, 1991), 8, $34,54,76$.

35 Sir William Wilde, Memoir of Gabriel Beranger and his Labours in the Cause of Irish Art and Antiquities, from I760 to 1780 (Dublin: M. H. Gill, I880), 26.

36 Harbison (1991), I3.

37 Petra Coffey, 'George Victor Du Noyer (1817-69), Artist, Geologist and Antiquary', in Michael Herity (ed.), Journal of the Royal Society of Antiquaries of Ireland (1995), Vol. I23, 102-19. 
Indeed, by way of his geological exploration of the development of human society, he is credited with discovering pre-historic houses at Faha on the Dingle Peninsula, and Neolithic tombs at Lough Crew in Co. Meath. Additionally, he was intimately involved in mapping the unique rock formations being exposed by the construction of the new railway running north and west from Dublin, which, coincidently, provided a unique record of Ireland's midnineteenth-century landscape, before the topological changes associated with the Industrial Revolution changed its appearance forever. ${ }^{38}$ Indeed, at a time when artists played an important role in producing scientific descriptions of artefacts, many of these exquisite sketches, in combining artistic skill with technical accuracy, became the field photographs of their day.

Similar to Beranger, Du Noyer's exquisite drawings and watercolours also recorded the relationship between the people and the land, wherein, he accurately depicted everyday 'activities' in his coastal perspectives, churches, lighthouses, street scenes, country markets, places of pilgrimage, and nature's bounty. ${ }^{39}$ Vastly prolific during his lifetime, Du Noyer left over 5,000 images which, in combing an objective scientific approach with a sublime artistic vision, were sketched on six-inch sheets of paper as he travelled the coastlines of Ireland, staying in rudimentary guest houses, while battling daily with the weather, poor nutrition and the risk of disease. Sadly, however, Du Noyer also remained undiscovered and undervalued for much of his life. Described as probably the most prolific Irish artist in the nineteenth century, who became a mere footnote in Irish art history, his under-appreciation was compounded by his all too late admission to membership of The Royal Irish Academy, ${ }^{40}$ and also by William Gladstone's parsimonious denial of his wife's request for a widow's pension, following her husband's untimely death at the age of fifty-two, just four days after

38 Gordon Herries Davies, 'Flowers among the Ruins', in F. Croke (ed.), George Victor Du Noyer I817-69: Hidden Landscapes (Dublin: The National Gallery of Ireland, 1995), 26.

Peter Murray, 'George Victor Du Noyer - Where and When', in Peter Murray and Petra Coffey (eds), Stones, Slabs and Seascapes: George Victor Du Noyer's Images of Ireland (Cork: Crawford Art Gallery, 2017), 47.

Mary Mulvihill 'An Artist True to his Subject', The Irish Times, 21 June 2003. 
contracting scarlet fever while carrying out a field survey in Co. Antrim, the day after his beloved daughter Fanny, who accompanied him on his expeditions, had succumbed to the same fate. ${ }^{41}$

\section{Associations with Built Heritage}

Following the bitter struggles of seventeenth-century Ireland, urban centres associated with an influx of Huguenot immigrants experienced a rapid regeneration, a particular highlight of which was the abundance of redbricked gable fronted houses of compact design known as 'Dutch Billies', so called because of their Huguenot owners' affiliation with King William of Orange. That said, the associated wealth generation also spawned a desire for more opulent town-houses. Indeed, a number of what are Dublin's best-known and most magnificent buildings are the creations of two architects of Huguenot extraction, whose monopoly of landmark commissions made a lasting contribution to beautifying what was then considered 'the second city of the British Empire'. ${ }^{42}$ Moreover, the popularity of what have become known as 'built heritage attractions' is clear from the large visitor numbers to the city's Georgian Squares, and the nation's 'stately homes', despite a lack of public awareness or knowledge of the Huguenot architects associated with them.

Recognized for his mastery of the Palladian style during the Early Georgian Period (1720-70), Richard Cassels (1690-175I), a Huguenot immigrant from Germany, was the most sought after architect in early eighteenth-century Ireland, whose extensive list of commissions included Tyrone House on Dublin's Marlborough Street (now The Department of Education and Science), Carton House in Maynooth, Westport House in Mayo, Powerscourt House in Enniskerry and Russborough House in

4I Murray, 'George Victor Du Noyer', 83.

42 Maurice Craig, The Architecture of Dublin, I660-1860 (Dublin: Allen Figgis, 1980), $86-7$. 
Blessington. ${ }^{43}$ Furthermore, Cassels was intimately associated with Iveagh House (now home to The Department of Foreign Affairs), which was once the townhouse of the Guinness family, the adjacent Newman House, which ironically became Ireland's first Catholic University in 1854, Leinster House (seat of the Irish government since 1922) and The Rotunda Maternity Hospital in Dublin's city centre. ${ }^{44}$

Built in 1745 as the largest mansion in the city for the then Earl of Kildare, James Fitzgerald, Leinster House is said to have remained 'unequalled in terms of its scale and grandeur' ${ }^{45}$ Indeed, such was its aweinducing beauty on completion, it became the model that inspired Irish architect James Hoban's design of America's famed 'White House' in Washington. ${ }^{46}$ That said, Cassels, like many of his fellow Huguenots, was also deeply humanitarian, evidenced in his willingness, while lying on his death-bed, to design a lying-in hospital that would ease the appalling circumstances in which the childbirth of Dublin's poorest took place. Moreover, not satisfied with merely designing what was to become Europe's first maternity hospital, Cassels waived his fee, while arranging for the commissioning of Barthelmij Cramillion, an exceptionally talented Huguenot stuccodore, to decorate the ceiling of the hospital's chapel with such astonishing Rococo representations of childbirth, that it has been described as 'possessing a scale and refinement not seen elsewhere in Dublin'. ${ }^{47}$

The Late Georgian Period (1770-1800) facilitated an important development in architectural styles, wherein the Neoclassical design of buildings and streetscapes became even more elegant, resulting in Dublin's reputation as the centre of architectural style being significantly enhanced. ${ }^{48}$ Central to this development, James Gandon (1742-1823), the son of a Huguenot gunsmith from London, was widely considered to have been the foremost

Jacqueline O'Brien, and Desmond Guinness, Dublin, A Grand Tour (London: Weidenfeld and Nicholson, 1994), 58-9.

44 O’Brien and Guinness, 74; 80.

45 O'Brien and Guinness, 88.

46 Liddy, Ioo.

47 Liddy, 55 .

48 O’Brien and Guinness, I30. 
Neoclassical architect of the period, whose buildings were ranked amongst the finest in Europe. At his creative peak, Gandon was responsible for the design of three of Dublin's most celebrated public buildings - The Custom House (then pivotal to Ireland's expanding shipping imports and exports), The Four Courts, and King's Inns (whose impressive dining hall remains the most impressive Gandon interior surviving in Dublin). ${ }^{49}$

Interestingly, much of Gandon's success was also attributable to his monopoly of the important public commissions that became available in Dublin as a result of radical proposals by the Huguenot influenced 'Wide Streets Commission'. Accordingly, in re-shaping the city as we know it today, Gandon was commissioned to build Carlisle Bridge over the River Liffey in 1785 , in order to facilitate improved commercial mobility for the city's merchant classes, which resulted in the development of two new streets (D'Olier Street and Westmoreland Street) as new traffic conduits, and which funnelled traffic past his well-known Corinthian portico of the Bank of Ireland, under which citizens and visitors pass to the present day. Indeed, such was the grandeur of Gandon's vision, that his bridge design originally included colonnaded footpaths, linking onto a shop-lined, widened avenue of Sackville Street (now O'Connell Street, Dublin's premier street), long before such a perspective was even considered in either London or Paris. ${ }^{50}$ Interestingly, using Gandon's original architectural concepts, Carlisle Bridge was re-constructed, widened and re-named O'Connell Bridge in honour of Daniel O'Connell in I880.

\section{Industrial, Educational, and Philanthropic Contributions}

A somewhat different, albeit less tangible heritage, is associated both with Ireland's most eminent engineer, and its most prominent Huguenot family. Considered the most significant figure in rail, road and canal construction

49 O'Brien and Guinness, 134; 177.

so O’Brien and Guinness, $133-4$. 
during the nineteenth century, William Dargan (1799-I867), a Carlowborn engineer of Huguenot descent, was a key influence on the economy and wellbeing of Ireland, particularly during the period of The Great Famine. ${ }^{51}$ Benefiting from the topographical insights of Du Noyer, Dargan completed Ireland's, and indeed, the world's first dedicated railway commuter line in I834, which stretched from Dublin's Westland Row to Dún Laoghaire. Moreover, he constructed over $\mathrm{I}, 300 \mathrm{~km}$ of trans-national rail connections which, in linking towns and villages with distant ports, ended social isolation, while simultaneously emboldening both prosperity and national identity by affording opportunities for farmers, fishermen, merchants and news vendors to transport and sell their produce in a wider range of marketplaces. Indeed, it is said that anyone who has travelled by train to Wexford, Waterford, Cork, Tralee, Limerick, Galway, Belfast, or on branch lines long since closed, has journeyed on lines built by Dargan. ${ }^{52}$

In visionary terms, Dargan's determination to bring Ireland into the industrial age and become self-sufficient, resulted in his funding of the Great Exhibition of Art and Industry in Dublin in 1853 which, in showcasing Irish and international works of art, inspired a welcome surge in national self-confidence at a time when Ireland was still reeling from the effects of Great Famine. Indeed, the exhibition attracted over I million visitors, many of whom travelled by way of his newly built Dublin-Belfast railway line. ${ }^{53}$ Following the Great Exhibition, Dargan further boosted national morale through being directly responsible for the creation of what became the National Gallery of Ireland. Indeed, a statue commemorating his 'laying the foundation for Ireland's future prosperity', stands on the entrance lawn to the gallery. Apart from being pragmatically entrepreneurial, Dargan also exhibited inspirational thinking when it came to town development. For example, following his design and construction of the Dublin-Wexford commuter line in 1856 , he converted the fishing village of Bray into a thriving

5I Fergus Mulligan, William Dargan: An Honourable Life 1799-1867 (Dublin: The Lilliput Press, 2013), 83-6.

52 Mulligan, 6.

53 Kenneth Mitchell, 'William Dargan: The Engineer who Rejuvenated a Nation on its Knees', Engineers Journal, 20 September (2016), 3. 
seaside resort, boasting hotels, Turkish baths, green promenades and commercial outlets, which for over a century, became the most popular holiday destination for many Irish families, who could afford little else. ${ }^{54}$

However, despite his extraordinary business acumen, Dargan was largely philanthropic throughout his life, evidenced in his insistence that his I,800 rail workers be paid 'on time' and 'in cash', rather than 'in kind' (food and alcohol), which was the norm practised by many employers at the time. Furthermore, during Ireland's Famine, he almost single-handedly revitalized the Irish economy by increasing his workforce to 50,000, paying them above the average wage. ${ }^{55}$ Additionally, though predominantly regarded for his railway, canal and road construction, Dargan was also responsible for creating much needed enterprise in areas of low employment by way of projects involving hotel construction (Dún Laoghaire and Malahide), sugar and flax production (Mountmellick, Cork and Chapelizod), and wetland reclamation in Wexford and Derry, the latter of which resulted in productive farmland being made available for impoverished farmers. ${ }^{56}$

Equally philanthropic and entrepreneurial was the La Touche family, four generations of whom were associated with considerations for the poor in Ireland, while paradoxically, being indelibly associated with the highflying pursuits of banking, property speculation, fine dining, and country pursuits. ${ }^{57}$ However, despite their spectacular wealth and privileged position, they, in common with their refugee antecedents from France, had a God-fearing reputation for hard work and probity which, ironically, found an outlet in a prodigious commitment to the provision of formal and structured education in Ireland at a time when the implementation of the infamous Penal Laws, in attempting to maintain a system of class domination, prevented Irish Catholics from attending school or university. ${ }^{58}$

54 Mulligan, William Dargan, I45; 168.

55 Mulligan, 218; 223.

56 Mulligan, 63-5, 166-78.

57 Michael McGinley, The La Touche Family in Ireland (Greystones: La Touche Legacy Committee, 2004), 25-34.

McGinley, 86-8; 164-6; 180-I. 
For example, by 1766 the La Touche family had become actively involved in the provision of vocational education, evidenced in their support for the the newly constituted Hibernian Marine School in Ringsend, which catered for the orphaned children of seafaring men, who were subsequently apprenticed at the age of thirteen or fourteen to the masters of trading ships. ${ }^{59}$ Furthermore, by 1773 , the family became associated with Ireland's first Charter Schools, which reached out to the poorest of the native Irish children whose parents, despite the objections of the Catholic clergy, viewed their attendance at these Protestant-led establishments, as a preferred alternative to near starvation. Similarly, they served on the governing committee of Kirwan House, a female orphanage which opened in Prussia Street in I79I to receive destitute girls between five and ten years of age, who were 'taught reading, writing and common accounts' in addition to learning 'every part of household work to qualify them as useful servants' ${ }^{60}$

Furthermore, in conjunction with Samuel Bewley and Arthur Guinness, they established the 'Society for Promoting the Education of the Poor in Ireland' (later known as The Kildare Place Society), which provided primary education to all without religious distinction. Accordingly, by 1816 , in addition to providing funding for the building of schools, they had made provision for the education of properly qualified teachers, thus initiating formalized teacher training, up to and including at university level. Finally, between 1880 and 1890 , Louisa Digges La Touche, during her time as Lady Principal of Alexandra College on St Stephens Green, played a major role in establishing university preparation courses for girls in Ireland, an opportunity, which, since the Penal Laws, had been declined to women in Ireland. ${ }^{61}$ Archeological and Historical Society Journal (2004), Vol. 4, 7.

60 Flannery, 8-I4.

6I Flannery, I3-I5. 


\section{Concluding Thoughts}

Sadly, by the end of the nineteenth century, the Huguenot colony as a distinct unit in Ireland had all but vanished, with many, following the enactment of Catholic Emancipation, having pragmatically married into Anglican or Catholic families in Ireland, or opportunistically re-emigrated to the rich Protestant lands of North America, South America, South Africa, Australia and New Zealand. ${ }^{62}$ And while it would appear on the surface that little evidence remains of their once extraordinary presence, apart from families who bear Huguenot names, some commemorative street names, remnants of 'Dutch Billy' houses in Dublin's 'Liberties', where Huguenot weavers once lived, scattered fragments of their fine arts and crafts, and the locked and lonely cemeteries where their bodies rest, this chapter argued that the 'patrimoine' of an ordinary group of fearful refugees and their descendants should be acknowledged in its own right, or perhaps re-imagined as a part of our own indigenous heritage, with its attendant tourism potential.

From an ideological perspective, the acknowledgement of Huguenots would appear to be quite reasonable, in that they might well be considered mirror images of the Irish; both were non-conformist, were persecuted for their religion and forced to emigrate, resulting in the loss of their land and possessions. Equally, both sought opportunity to better themselves, and contributed significantly to the territories that they subsequently inhabited. Indeed, during the nineteenth century, the Irish became the most emigration-prone people in Europe, when in the period between the Battle of Waterloo and the Great Famine, they constituted about one third of those who migrated from the Old World to the New World ${ }^{63}$ which would suggest that we might comfortably identify with the migrational experiences of a community of like sufferers or opportunists.

62 Gwynn, 186.

63 Cormac Ó Gráda, Jewish Ireland in the Age of Joyce: A Socioeconomic History (Princeton, NJ: Princeton University Press, 2006), 9. 
That said, one might then wonder why Huguenots are at best, underrepresented in commemorations of Ireland's 'heritage'? Unfortunately, however, throughout history, the heritage imprints of migrant communities, be they tangible or intangible, have often grated on what were the 'intrinsic' value systems of the recipient community. Accordingly, from a commemorative perspective, Huguenots, like other Protestant participants, were caught in the cultural crossfire of the historically polarizing Battle of the Boyne, which created a centuries-old contested heritage between northern Protestants and the Catholic community in the south, for whom it was historically redacted. Nonetheless, it would appear that local communities increasingly organize commemorative conduits to celebrate their unique, or long forgotten, heritage with the intention of attracting visitor numbers to celebrate with them. Therefore, in considering the extraordinary tapestry of Huguenot heritage contributions, ranging from the highflying associations with banking, land speculation, engineering, architecture and artisan crafts, to the more ordinary, albeit equally significant recording of Ireland's topographical heritage and philanthropic commitment, there is little doubt that Huguenot immigrants and their descendants, have arguably created the potential for a shareable heritage.

Sadly, however, it would appear that the Huguenot contribution to Ireland's cultural and material assets has become much neglected over the years, wherein the only 'recognizable' vestige of their presence in Ireland consists of two non-conformist graveyards, on Dublin's Merrion Row, and on Cork's Carey's Lane, which ironically, without the financial assistance of the French government, would likely not exist. Accordingly, incongruous as it might seem, Huguenots are almost invisible on Ireland's heritage landscape, in that though much of their architectural contribution is instantly recognizable, we are, generally speaking, unaware of their Huguenot associations. Additionally, we see a plentitude of gold and silver collections in our museums, with little or no reference to their Huguenot origin. We happily celebrate our native landscape painters, while our Huguenot topographical artists often remain hidden and under-celebrated in our antiquarian institutions. Equally, while we rightly acknowledge the commitment of Catholic religious orders to the education and care of the less well off, Huguenots, by way of their humanitarian disposition, were also a 
force for decency in Ireland, evidenced in the much neglected La Touche family's commitment to education for the poor, and Dargan's concern for his starving workforce.

In considering how our Huguenot heritage might be re-imagined, there would appear to be an opportunity to develop a form of relational tourism by way of Huguenot trails stretching from Lisburn in Antrim, to Cork, that would connect their descendants with what for them, might translate into places of memory, and where their curiosity might be piqued by visiting areas within cities and towns associated with the lives of their own antecedents, while at the same time, highlighting for ordinary citizens, the significance of such contributions.

In conclusion, it would seem that although we may have unconsciously adopted a blinkered or conditional approach to celebrating our Huguenot inflected heritage, we have done so for far too long. Indeed, in an era when both national and local heritage are being employed to attract visitors and excite the curiosity of the local population, perhaps Canon William Neely had a point in arguing that Irish people should take pride in an 'alternate' heritage, such as that represented by our Huguenot immigrants. Moreover, it may not be entirely fanciful to suggest that perhaps the time has also come to re-imagine our Huguenot heritage not as 'alternate', but perhaps as the template for viewing the potential of the new migrants who today arrive on our shores, who may at first sight appear to be 'ordinary', but who may well also have the potential to become 'extraordinary'. 



\section{The Reification of Sceilg Mhichíl}

The history of Skellig Michael is shrouded in mystery. From the earliest times to the present, memories of shipwrecks, ghosts and graveyards have associated the place with death and the Otherworld. The choice of St Michael, the arch-enemy of satanic forces, as patron saint of the rock reinforces the grim feeling that its steep slopes and barely accessible peaks have been a key battleground for the endless struggle between light and darkness, good and evil, life and death. The scanty evidence that has survived from the distant past leaves ground for so many conjectures that imagination and irrationality have surreptitiously found their way to the heart of rational modern and contemporary interpretations of the site, to the extent that it is difficult to know if the heritage of Skellig Michael that is being handed down to present and future generations is a fake or not. Yet preservation and conservation have been on the agenda for decades, particularly since 1996, when the island and its early monastic remains were added to the list of UNESCO World Heritage Sites.

Heritage policies naturally raise several questions. Should ancient sites be made untouchable, turned into museums and venerated as sacred ${ }^{1} \mathrm{Or}$ should life be breathed into them for fear that heritage might come to be understood as fixed, inert, in other words, dead and irrelevant? $?^{2}$ In any case, heritage is a social construct, and attitudes to it are but one aspect of the

I Christophe Charle argues that there are similarities between the cult of saints in the Middle Ages and the cult of heritage sites today. 'Pour une sociologie historique du patrimoine', in Temps croisés I, eds Duanmu Mei and Hugues Tertrain (Paris: Editions de la maison française des sciences de l'homme, 2010), 32.

2 'Faire passer dans notre patrimoine le souffle de vie et en finir avec une vision trop répandue selon laquelle le patrimoine ne serait qu'un ensemble de choses inertes', Rapport Querrien, 1982, quoted by Dominique Poulot, 'De la raison patrimoniale 
tyranny of the present over the past. This article will examine Skellig Michael from this perspective. Because of the rich folklore associated with the site and possible parallels that can be drawn with comparable sites in Europe, I will also argue that the site's intangible heritage deserves as much attention as its already well-known cultural and natural heritage features enjoy.

Just like all World Heritage Sites, Skellig Michael was considered for inscription on the UNESCO list on account of its 'outstanding universal value'. ${ }^{3}$ According to its Management Plan 2008-2018, it is the interaction between the monks of Skellig Michael and the island's topography in what was physically a harsh environment that gives the site its outstanding universal value. ${ }^{4}$ Besides, 'the Skelligs islands have been recognized as two of Ireland's most important sites for breeding seabirds for several hundred years.' The Management Plan was elaborated by the Irish Department of the Environment, Heritage and Local Government and the Office of Public Works. ${ }^{6}$ Over the years, the mission of the OPW has been 'to protect, conserve and promote an appreciation of Skellig Michael'.

As is generally the case with heritage sites, Skellig Michael has been an important asset for the economic development of the Iveragh Peninsula and a balance has been sought between economic and conservation imperatives, in particular to address what Mark McCarthy calls 'the complex outcomes

aux mondes du patrimoine', Les mondes du patrimoine, Socio-anthropologie 19 (2006), $<$ https://socio-anthropologie.revues.org/753>. [Accessed 29 April 2017].

It is held to have 'cultural and [...] natural significance which is so exceptional as to transcend national boundaries' and to be 'of common importance for present and future generations of humanity'. Skellig Michael World Heritage Site Management Plan 2008-I8 (2008), 21, <http://www.ahrrga.gov.ie/app/uploads/2015/ro/skelligmichael-world-heritage-site.pdf $>$. [Accessed 29 April 2017].

4 Site Management Plan, 19.

5 Site Management Plan, 4.

6 OPW website, Heritage Services, <http://www.opw.ie/en/heritage/>. [Accessed 29 April 2017]. The Office of Public Works is in charge of 'caring, maintaining and operating the country's most important heritage sites'.

7 This has involved supervising major archaeological excavations and conservation work, and publishing a ground-breaking stratigraphic report summarizing the results of archaeological campaigns from 1986 to 2010. 
of commodifying heritage for tourism and other purposes. ${ }^{8}$ It is clear that the case of Skellig Michael perfectly exemplifies all the tensions that arise from the need to combine preservation and market criteria or environmental protection and the development of tourist attractions, amenities and services. Since 2008 and the beginning of the financial crisis, government policy has shifted towards a greater and greater instrumentalization of heritage for economic gain as is made clear by the Heritage Council's Strategic Plan for 20I2-I6, which stresses 'the need to contribute to national recovery and to demonstrate how heritage can be a resource for social and economic development.' Supporting employment has become a priority in this context, even if the Council remains committed to the defence of heritage as 'a vital part of our identity and sense of place'. ${ }^{10}$

It is generally understood that the Minister for Culture at the time, Heather Humphreys, ${ }^{11}$ enthusiastically welcomed the filming of Star Wars episodes 7 and 8 on Skellig Michael because it meant jobs, indirectly promoted tourism and boosted the Irish film industry. However, her controversial decision was deliberately taken to be in breach of long established conservation policy for the World Heritage Site' and in defiance of An Taisce's warning about 'potential adverse impacts on ecology and archaeology as well as general site impact disturbance. ${ }^{12}$ There is evidence that the site was actually damaged during the filming, ${ }^{13}$ but the

8 Mark McCarthy, 'Historico-Geographical Explorations of Ireland's Heritages. Towards a Critical Understanding of the Nature of Memory and Identity', in Ireland's Heritages: Critical Perspectives of Memory and Identity, ed. Mark McCarthy (Aldershot: Ashgate, 2005), 4.

9 The Heritage Council, Strategic Plan 20I2-I6, 6, <http://www.heritagecouncil.ie/ content/files/strategic_plan_2012_2016.pdf $>$. [Accessed 29 April 2017].

Io Heritage Council, Strategic Plan.

II Heather Humphreys was Minister for Arts, Heritage and the Gaeltacht from 2014 to 2016.

I2 An Taisce, 'Letter to Heather Humphreys TD', 20 August 2015, <http://www. antaisce.org/sites/antaisce.org/files/re_proposed_star_wars_filming_on_skellig michael_world_heritage_site.pdf $>$. [Accessed 29 April 2017].

I3 Lorna Siggins, 'Star Wars Filming behind 'Incidents' on Skellig Michael', The Irish Times, 26 September 2015, <http://www.irishtimes.com/news/ireland/irish-news/ 
government obviously deemed commercial benefits more significant than any harm that may have been done to the island. Further concern is raised by the confidentiality clauses protecting Disney-Lucasfilms' intellectual property ${ }^{14}$ and the rumour of a Walt Disney Company digital copyright of Skellig Michael that might make it illegal for anyone to upload images of the island for ten years. ${ }^{15}$ Twenty years ago Ruth McManus perceptively noted that the commodification of heritage involved the risk of Disney-ification of the past. ${ }^{16}$ Little did she expect in all likelihood how literal the threat might become.

What she had in mind at the time was the process that made it possible to turn heritage into tourist attractions, which implied the elaboration of a fake authenticity based on a biased, distorted and oversimplified interpretation of the Irish past for tourist consumption. Fáilte Ireland's current 'Visitor Experience Development' policy for the Skellig coast echoes this analysis. It is also reminiscent of the Tourist Board's 1997 'Ireland - Live a Different Life' campaign that emphasized 'emotional experience' as 'the core brand essence for Ireland tourism. ${ }^{17}$ The Operator Workbook actually

star-wars-filming-behind-incidents-on-skellig-michael-1.2366928>. [Accessed 29 April 2017].

I4 Fintan O’Toole, 'Beyond Belief - Why grant Disney's Skelligs Wish for Star Wars?', The Irish Times, I September 2015, <http://www.irishtimes.com/opinion/fintano-toole-beyond-belief-why-grant-disney-s-skelligs-wish-for-star-wars-I.2335310>. [Accessed 29 April 2017]. In Fintan O’Toole's estimation, 'once Skellig Michael becomes Luke Skywalker's refuge, [...] it ceases to be the edge of the world and becomes one of the world's quotidian commodities'.

Is Vox Hiberionacum, 'Disney to Enforce Star Wars Copyright of Skellig Michael for Ten Years' (April 2016) <https://voxhiberionacum.wordpress.com/2016/04/OI/ disney-star-wars-copyright/>. [Accessed 29 April 2017].

I6 Ruth McManus, 'Heritage and Tourism in Ireland - an unholy Alliance?', Irish Geography 30, no. 2 (1997), <http://irishgeography.ie/index.php/irishgeography/ article/view/385>. [Accessed 29 April 2017].

I7 Quoted by Mark McGovern, “'The Cracked Pint Glass of the Servant”: The Irish Pub, Irish Identity and the Tourist Eye', in Irish Tourism: Image, Culture and Identity, eds Michael Cronin and Barbara O'Connor (Cleveland, Buffalo, Toronto, Sydney: Channel View Publications, 2003), 96. 
recommends visitors to submit 'unique selling propositions ${ }^{\text {'18 }}$ based on 'experiential tourism' because its authors believe that 'visitors who feel they are getting authentic and immersive experiences are willing to spend more, stay longer and visit again'. Unsurprisingly, 'Journeys inspired by the Skelligs monks' feature prominently among the 'quests' inspired by the saleable aspects of the local history listed in the booklet. ${ }^{19}$ The 'Skellig Experience Visitor Centre' actually offers the visitor the possibility to 'experience many aspects' of the island 'while remaining on dry land'. ${ }^{20}$

Reification however does not stop there. Recent controversies over OPW conservation policies suggest that the archaeological site itself may be the victim of overzealous archaelogists' imagination. The controversial restoration of some of Skellig Michael structures has caused alarm among several experts, in particular field archaeologist Michael Gibbons whose dramatic call in 2006 led to a UNESCO mission in 2007. In October 2006, the Tara Foundation had uploaded a video on YouTube entitled 'Skellig Michael: The Fabrication of History ${ }^{21}$ that pointed at the damage caused by the conservation policy. It accused the Office of Public Works of substituting conjecture for evidence and investigation and of destroying the authenticity of the site. Michael Gibbons himself commented that 'the potential value of Skellig Michael for future researchers is being destroyed', since 'genuine archaelogical remains have been replaced by faux-monastic twentyfirst century imitations. ${ }^{22}$ The UNESCO mission eventually confirmed

Fáilte Ireland, Skellig Coast - Visitor Experience Development Operator Workbook (2016), 7, <http://www.failteireland.ie/FailteIreland/files/3d/3d865a5b-cd6o-4f 72 972f.-cb9634ba3ffb.pdf $>$. [Accessed 29 April 2017].

I9 Skellig Coast, 5 .

20 'Experience the Skellig islands', The Skelligs Experience Visitor Centre website, <http://www.skelligexperience.com/>. [Accessed 6 May 2017].

2I 'Skellig Michael: the Fabrication of History', <https://www.youtube.com/

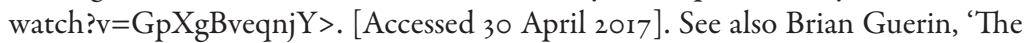
Importance of Skellig Michael', Tara Foundation Magazine (Winter 2007/2008), <http://www.tara-foundation.org/The-importance-of-Skellig-Michael.php>. [Accessed i May 2017].

22 Michael Gibbons, 'Restored to death? Skellig Michael's World Heritage Status under Threat', in 2oth Century/Contemporary History, 3 (May/June 2007) and History 
Skellig Michael's World Heritage status but noted the obvious alterations, damage and tentative reconstructions provoked by restoration crews. Not only is the fabrication of heritage a sign of the tyranny of the present over dead generations, but it is a sign of its tendency to model representations of the past for future generations ${ }^{23}$ within the framework of what Martine Fournier calls 'patrimonially correct' UNESCO policies. ${ }^{24}$

Whether deliberately or inadvertently, imagination and emotion are actually never far away when it comes to discussing Skellig Michael and the island is moulded to suit the needs, dreams or wishes of visitors. Even Michael Gibbons gets carried away in a YouTube video where he unquestioningly evokes the sixth- and seventh-century monks who supposedly settled on the island 'to worship Our Lord' and 'keep the Devil at bay.25 First, the Official Archaeological stratigraphic report published in 2010 indicates that it is impossible to date stone buildings except St Michael's Church, which may fairly safely be ascribed to the tenth century, and the carbon dating of finds, including human remains, shows that none of the artefacts recovered may be older than the seventh century. ${ }^{26}$ As for the first mention of the monastery in a written document, it dates from the eighth century. Nothing is known about its origins, and the tradition of its creation by St Fionan in the sixth century appears a fabrication of legend. In an

Ireland, <http://www.historyireland.com/2oth-century-contemporary-history/ restored-to-death-skellig-michaels-world-heritage-status-under-threat/>. [Accessed 30 April 2017].

23 Jean Davallon, 'Comment se fabrique le patrimoine', Sciences humaines, <https:// www.scienceshumaines.com/comment-se-fabrique-le-patrimoine_fr_I2550.html >. [Accessed 30 April 2017].

24 Martine Fournier, 'l'obsession patrimoniale', ibid.

25 Michael Gibbons, <https://www.youtube.com/watch?v=ON4viTBRUJg>. [Accessed 30 April 2017].

26 Edward Bourke, Alan Hayden and Ann Lynch (eds), Skellig Michael, Co Kerry: The Monastery and South Peak - Archaeological stratigraphic report: excavations Ig86-2010 (Dublin: Department of Arts, Heritage and the Gaeltacht and OPW, 2010), 369-71. Pdf version <http://www.worldheritageireland.ie/fileadmin/ user_upload/documents/Skellig_Michael_Excavations_Intro.pdf $>$. [Accessed 30 April 2017]. 
article published in 1994, French archaeologist Christian Lassure goes as far as to express doubt concerning the antiquity of the so-called monastic cells, which are not attested before the middle of the eighteenth century. In his estimation, there is no proof that they were ever part of the initial monastery. ${ }^{27}$ As for Gibbons's reference to the Devil coming 'from the four corners (dark corners) of the world', ${ }^{28}$ it undoubtedly comes from legendary traditions for which no incontestable evidence exists.

It appears in reality that there is much more to Skellig Michael than the tangible heritage, made up of buildings and artefacts. The Management Plan 2008-I8 itself does acknowledge the existence of a form of intangible heritage there but it does so in very vague terms:

The presence of the monks on the island for such a long period of time has bequeathed us more than just physical remains. They have imbued the place with a strong sense of spirituality, which is palpable to anyone who has had the opportunity and privilege of spending time there. The physical remains bear testament to the remarkable achievements of the monks, which cannot fail to invoke a sense of wonder and awe. ${ }^{29}$

Testimonies by early visitors to the site, the rich local lore and intriguing documents of various kinds point at much more than that subjective feeling. They also suggest a more complex history than the usually accepted story, which runs as follows: some time in the seventh century, early Christian monks left the mainland to live an ascetic life on Skellig Rock as was customary in the early Irish Church. Exposed to incredibly harsh conditions, confronted in due course to Viking raids, several generations of monks are said to have endured hardships until the late twelfth or early thirteenth century, when they left the island to settle in Ballinskelligs' Augustinian

Christian Lassure, 'Les cabanes en pierre sèche de Skellig Michael (Comté de Kerry, Irlande): vestiges authentiques du monastère du Haut Moyen-Age, fabrique mystique des XVIe-XVIIe siècles ou casemates à poudre pour la construction du phare du I9 ${ }^{\mathrm{e}}$ siècle?', L'archéologie vernaculaire I8 (1994), <https://www.pierreseche.com/ mythe_skellig.html >. [Accessed 30 April 2017]. Michael Gibbons, <https://www.youtube.com/watch?v=ON4viTBRUJg>. [Accessed 30 April 2017]. 
monastery. There is evidence that Skellig rock was not abandoned at that stage and it is said to have become and remained a major European pilgrimage site throughout the Middle Ages and later centuries. ${ }^{30}$ Whatever complements may be added to this uncontroversial summary rest on interesting coincidences and largely unexploited sources.

The forgotten heritage of Skellig Michael has attracted the attention of few academics and the only detailed - but still very limited - analysis of the question is a 2012 article by Máiréad Nic Craith, entitled 'Heritage Politics and Neglected Traditions: A Case-Study of Skellig Michael'. ${ }^{31}$ Apart from the lighthouse-keeping and sailors' narratives, which are of no interest to us here, what the author sees as a 'unique aspect of the island's intangible heritage' is the tradition of Skellig Lists, which, she says, 'remain a vastly under-researched resource.' ${ }^{32}$ The Skellig Lists are the remnants of matchmaking and wedding customs that were still vivid when the Irish Folklore Commission investigated the matter. They take the form of rhymes that seek to ridicule bachelors and old maids into going on pilgrimage to Skellig Michael on Shrove Tuesday in order to repent of their sins, embark on a courtship in the hope of finding a suitable partner. There is evidence that the visit to Skellig was the cause of much merriment on the mainland as well as on the island. Lady Wilde writes that 'the proceedings degenerated into such mad carnival of drinking and fun that priests denounced the pilgrimage and forbade the annual migration to the Skelligs. ${ }^{33}$

It can be argued that there is more than meets the eye in this intriguing practice. To start with, it refers to a time when the monks of Skellig accepted to conduct marriages later in the year than was allowed by the

In 1756, Charles Smith noted that the pilgrimage attracted fewer devotees at the time of writing than twenty years previously, but it survived until well into the nineteenth century. Máiréad Nic Craith, 'Heritage Politics and Neglected Traditions: A Case-Study of Skellig Michael', in Heritage Regimes and the State, eds Regina Bendix, Aditya Eggert and Arnika Peselmann (Göttingen: Göttingen Studies in Cultural Property Vol. 6, Universitätsverlag Göttingen, 2012), I67-8.

32 Ibid. 170.

33 Lady Wilde, Legends, Charms and Superstitions of Ireland (Mineola, NY: Dover Publications, (1919) 2006), 255. 
Church on the mainland. In those days, marrying was prohibited during Lent but curiously Lent apparently started later on the island than elsewhere and late marriages were possible. The usual explanation according to which the monastery retained the Julian calendar after the introduction of the Gregorian calendar in 1583 is hardly convincing since Ballinskelligs Abbey, which owned the island and controlled pilgrimages there, had been closed five years previously, as a result of Elizabeth I's Reformation policy. The monks had deserted the island centuries before anyway. The only other possible interpretation takes us back to the controversies between the early Irish Church and Rome over the computation of the date of Easter. The Synod of Whitby brought the Irish Church into conformity with Rome in 664 but if this conjecture is correct, we have to admit that, for some reason, the monastery on Skellig Island may have been left out of the agreement, or else that in the early years of its existence, it was associated with preChristian practices. Indeed, coincidentally, the late date of Easter in the early Church brought its celebration close to i May, the old seasonal festival of Bealtaine, the end of the dark half of the year, which was associated with sun worship, and took the form of fire rituals. Very little is known about this festival except that it had to do with fertility. In later Irish folklore, May Day dew was expected to enhance sexual attractiveness, and sexual license was part of the annual festival in England, ${ }^{34}$ which is consistent with later traditions associating May Day with courtship. ${ }^{35}$ The tradition of the pilgrimage of bachelors and spinsters to Skellig Michael is an interesting coincidence in this perspective.

The suspected association of Skellig Michael with Easter and Bealtaine goes further as the medieval and early modern penitential pilgrimage precisely took place at Easter. Besides, according to the twelfthcentury authors of Lebór Gabála Érenn, The Book of the Taking of Ireland, the landing of the sons of Míl in Ireland on May Day is associated with the Skellig area. Three of the brothers unhappily drowned off the coast

Patricia Monaghan, The Encyclopedia of Celtic Mythology and Folklore (New York: Facts on File, 2004), 42.

35 Carl Lindhal, John McNamara and John Lindow, Medieval Folklore: A Guide to Myths, Legends, Tales, Beliefs and Customs (Oxford: Oxford University Press, 2000), I8. 
of Kerry, among them Ir, whose body was taken to the island of Skellig, and his eldest brother, Donn, leader of the expedition and Milesian king, who was buried in nearby Bull Island, also named after him as Donn's House, or Tech Duinn. ${ }^{36}$ This episode is all the more interesting as Ir's burial place is described as 'Sceilic of the spectres, ${ }^{37}$ while a ninth-century poem recalls Donn's 'mighty testament to his hundredfold offspring' in the following terms: 'You shall all come to me, to my house, after your death. ${ }^{38}$ Skellig Rock and Bull Island therefore featured as realms of the dead in a region of Ireland traditionally associated with the Otherworld. In collective memory, Donn became an image of the Lord of the Dead, who takes the souls of the departed to the Otherworld. In later folklore, he was seen as 'galoping [sic] in the clouds' on stormy nights, ${ }^{39}$ while ghosts haunted the coasts of Skellig Michael.

In their seminal book on Celtic Heritage, Alwyn and Brinley Rees estimate that the initial pilgrimage to Skellig Michael, probably connected to the cult of Donn, was 'manifestly pre-christian', as it involved a classic mountain-climbing ritual. ${ }^{40}$ Indeed, pilgrims had to heave their way up the precipitous slopes of the South Peak, squeeze through the 'needle's eye', a narrow chasm between two rocks and finally kiss an upright stone jutting out of the summit. Often identified as a cross by contemporary archaeologists, this stone certainly didn't look like one, as is made clear by the photos taken before it disappeared in the late I970s. Often referred to as 'the stone of pain', it was mysteriously called 'Stone of Donn', on a map drawn by John Windele, who visited the island in I85I, which is another

R. A. Stewart Macalister, Lebór Gabála Érenn (Dublin: Irish Texts Society, 1956), section VIII, 3I-73.

38 Poem by Mael Muru of Othan (died AD 887), quoted by Bruce Lincoln, Death, War and Sacrifice, Studies in Ideology and Practice (Chicago: Chicago University Press, 1991), 34 .

Ali Isaac, 'Donn, the Mysterious Lord of the Dead', Irish Central, <http://www. irishcentral.com/roots/donn-the-mysterious-irish-lord-of-the-dead $>$. [Accessed I May 2017]. Alwyn and Brinley Rees, Celtic Heritage (London: Thames and Hudson, I96I), 98. 
interesting coincidence. ${ }^{41}$ Yet witnesses also described a cross carved on the stone, and the Christian penitential pilgrimage is well attested in the Middle Ages, once the monks had settled in Ballinskelligs.

Several legends suggest that this highly symbolic site was Christianized at an early date, as were so many other pagan sacred places. It is interesting in this respect to note that tradition ascribes the creation of the monastery to sixth-century Saint Fionan, but that it is not included in the extant list of his foundations. This is all the more intriguing as it has been argued that 'the cult of Fionan probably replaced the cult of pagan god Lug, both in Northwest Donegal and in South-West Kerry. ${ }^{42}$ This would certainly be consistent with a local tradition of seasonal battles between the solar god Lug and the forces of darkness embodied by Donn. As in Lough Derg, it would seem that St Patrick himself was called to the rescue and added to the legend at some stage to contribute to saving souls from Purgatory. The tradition - unconfirmed by archaeological excavations - that there used to be an underground tunnel on Skellig rock, 'rediscovered and blocked again by the departing monks', ${ }^{43}$ confirms that just like Lough Derg, it might have been a privileged entry to the Sídh.

In this perspective, the legend according to which St Patrick's ultimate battle with the serpents took place on Skellig Rock deserves special mention, especially as the site was eventually dedicated to St Michael some time between 950 and $1044 .{ }^{44}$ The very dedication of the site to this most

4I The map is reproduced in Walter Horn, Jenny White, and Grellan Bourke, The Forgotten Hermitage of Skellig Michael (Berkeley, Los Angeles, Oxford: University of California Press, 1990), 17.

42 Dónall McGiolla Easpaig, 'Placenames and early settlement in county Donegal', in Donegal: History and Society, eds William Nolan, Liam Ronayne and Máiread Dunleavy (Dublin: Geography Publications, 1995), 167-8.

43 Brad Olsen, Sacred Places - Europe: 1o8 Destinations (San Francisco, CA: CCC Publishing, 2007), 83.

44 In the Annals of the Kingdom of Ireland by the Four Masters, entries for these two dates refer to the monastery. One reads 'Age of Christ, 950. Blathmhac of Sgeillic died'; the other reads 'The Age of Christ, I044. Aedh of Sgelic-Mhichil'. This is the first reference to the monastery's new name. Historians suggest that it was dedicated to St Michael some time between these two dates. Edited by John O'Donovan 
symbolical saint is highly significant since a parallel can be drawn between the dragon slayer and the man who banished snakes from Ireland. In both cases, we may suggest that the serpent is another name for Satan embodying paganism. There is evidence that the cult of St Michael developed in Ireland in the tenth and eleventh centuries. It has also been suggested that Irish traditions about St Michael influenced perceptions on the continent. A curious story whose first mention can be found in an eleventh-century French manuscript written by Baudri de Bourgueil, bishop of Dol, tells about a short sword and shield that were venerated at Mont St Michel. These weapons were supposed to have been used by St Michael to kill the dragon in Ireland. According to the legend, the archangel asked Irish peasants to bring them to his dedicated mount on the continent. They first mistook the place for Monte Gargano in Italy before they were eventually advised by Michael to go to Normandy. The story became a standard element of the legendary history of Mont St Michel and witnesses commented that they had seen the sword and shield up until the end of the nineteenth century. ${ }^{45}$

Interestingly, both Mont St Michel, linked to the nearby island of Tombelaine, and Monte Gargano in Italy, now both dedicated to the archangel, were previously associated with Celtic Pagan God Gargan and his father Belenos, celebrated at Bealtaine, who seem to have shared many characteristics with the Donn/Lug couple. Both Gargan and Donn have been assimilated to the god Julius Caesar called the Dis Pater, a father figure, perhaps another face of the Dagda, the master of life and death, who reigned over the land of the dead and ensured the passage between this world and the next. Another parallel between these sites is that they were intially associated with graves and upright stones, probably of neolithic origin, that used to stand at the top of the hills. Lord Dunraven noted in

(Dublin: Hodges, Smith \& Co., 1856), vol. 2, 666-7 and 844-5. Pdf version. <https:// ia902705.us.archive.org/3/items/annalsorodonuoft/annfaalsorodonuoft.pdf $>$. [Accessed 3 May 2017].

45 Dom Jean Huynes, Histoire générale de l'Abbaye du Mont St Michel au Péril de la Mer (Rouen: A. Le Brument, I872), 137-46, <http://gallica.bnf.fr/ark:/12148/ bpt6k486064z>. [Accessed 2 May 2017]. Maximilien Raoul, Histoire pittoresque du Mont St-Michel et de Tombelène (Paris: Librairie Abel Ledoux, I834), I55. 
his classic description of Skellig Michael in 1875 that Ir 'was buried near the summit of the rock, where a cromlech was standing up to a late period, ${ }^{46}$ and there are similar comments about the continental sites. To this, we may add two arguably relevant insular traditions about St Michael: first, the medieval Irish tradition according to which St Michael conducted the dead to judgement and, second, what Maria Elena Ruggerini analyses as 'the unusual iconography whereby St Michael is represented as a bird'. ${ }^{47}$ If we admit that in pagan Celtic times birds were the messengers of the Otherworld, we may suggest that the dedication of Skellig rock to St Michael served the purpose of both taking over local pagan traditions and symbolizing the victory of Christianity over paganism.

In spite of all this, Windele's curious account of an ancient cult of the dragon on Skellig Michael in I85I was dismissed by Peter Harbison without much further examination in the $1970{ }^{48}{ }^{48}$ In the same way, if we except the reference to The Book of the Taking of Ireland, no allusion is made to possibly pre-Christian traditions in the sanitized interpretation of Irish history for tourists. This leads us to an examination of the ideological dimension of heritage when it comes to mirroring and projecting a certain perception of Irish identity.

It can easily be argued that the implicit message conveyed by today's official presentation of Skellig Michael and the Skellig Coast is derived from early twentieth-century conceptions of Irish identity. It is particularly associated with the deep faith of a Christian country, as it takes the shape of the celebration of the early monks' extreme form of asceticism, but the link with traditional Irish national identity markers doesn't stop there. In 2012, the Irish government expressed the wish that the official name of Skellig Michael be changed, which the UNESCO approved. Since then,

46 Lord Dunraven, Notes on Irish Architecture (London: G. Bells and Sons, I875), 34 , <https://archive.org/details/gri_33125007823475>. [Accessed 5 May 2017].

47 Maria Elena Ruggerini, 'St Michael and the Dragon from Scripture to Hagiography', in Monsters and the Monstrous in Medieval Northwest Europe, eds Karin Olsen and Luuk Houwen (Leuven: Peeters, 200I), 39.

48 Peter Harbison, 'John Windele's visit to Skellig Michael in I851', Journal of the Kerry Archaeological and Historical Society 9 (1976). 
'the name of the property' has been 'Sceilg Mhichíl in English as well as in French', ${ }^{49}$ a sign that globalized Ireland claims its attachment to the Gaelic language and culture more than ever. It can finally be argued that in the same way as George Petrie pressed for an understanding of Newgrange as the epitome of the modern nation's culture, ${ }^{50}$ nineteenth-century descriptions of Skellig Michael, particularly that of Lord Dunraven in I875, served the same purpose. ${ }^{51}$ Yet in recent documents, the nationalist component of heritage in the Skellig area mostly focuses on its connection with Daniel O'Connell, which makes it 'the cradle of Ireland's nationhood'.52 However, it is also 'the cradle of Gaelic civilisation' as 'the location of the first successful Gaelic or Milesian landfall in Ireland.'53

It is quite striking that globalized, de-Christianized, post-nationalist Ireland should resort to the old-fashioned identity markers of the de Valera era to attract contemporary tourists. This may be an Irish illustration of Jean Davallon's analysis of today's 'obsession with heritage' as 'an original form of continuity production in a society that emphasizes rupture and innovation rather than reproduction and tradition. ${ }^{54}$ It may also be a marketing strategy carefully elaborated by those who are trying to sell the kind of Ireland that the 'key market segments of the Skellig Coast', that is to say 'the culturally curious' and 'the great escapers', want to find and are willing to pay for. ${ }^{55}$ Such cynicism stands in sharp contrast with the tone of fisherman Des Lavelle's classic account, The Skellig Story, first published in 1976 , which was obviously inspired by the author's love for the place and his desire to share his passion with visitors. ${ }^{56}$

UNESCO 'Changes to Names of Properties Inscribed on the World Heritage List: Sceilg Mhichíl’, Decision 36 COM 8B.2, <http://whc.unesco.org/en/decisions/4773>. [Accessed s May 2017].

50 George Petrie, 'New Grange', Dublin Penny Journal I (I832), 305-6.

5I Lord Dunraven, Notes on Irish Architecture, 23-35. (Have you cited this already? If not, bibliographical details please).

52 Fáilte Ireland, Skellig Coast - Visitor Experience Development Operator Workbook, 32.

53 Skellig Coast, 33.

54 Jean Davallon, 'Comment se fabrique le patrimoine', 5.

55 Fáilte Ireland, Skellig Coast - Visitor Experience Development Operator Workbook, 7.

56 Des Lavelle, The Skellig Story (Dublin: The O’Brien Press, (1976) 1993). 
Nevertheless, the pagan subtext of Skellig Michael's history has reemerged with force in the past few years and the island has again become a place of pilgrimage for those who have left traditional religions behind and are attracted to alternative spiritualities of all kinds. The adepts of Celtic Christianity and Celtic neopagans see it as a 'thin place', where they believe 'encounter with the Holy is immediate and overwhelming. ${ }^{57}$ Pilgrimage to the island has thus been interpreted as 'a rehearsal for the soul's journey to eternity', ${ }^{58}$ on account of the old associations with the pagan islands of the Otherworld and St Michael. New Age activists who believe in the existence of ley lines ${ }^{59}$ also see Skellig Michael as a very special place at the far end of the St Michael or Apollo line, that is the alignment of ancient sites historically linked with sun cults and dedicated to St Michael. In a video posted on YouTube, a group of such British visitors enthusiastically note that this line is running through the row of beehive huts and they feel Apollo and Athena currents spiralling together as in a dance. ${ }^{60}$ For the same reason, a young Irish woman who calls herself MaRa LuaSa sees Skellig Michael as an 'ancient planetary portal of light', 'a beacon for celestial energies', 'a portal for the divine masculine to emerge', in a word 'a power node' that 'must be protected by us, children of Gaia', especially as both forces of darkness and light can be felt to operate at this place of extreme planetary importance. ${ }^{61}$ There is little doubt that the adepts of Jediism, the new religious movement based on the philosophical teachings of the fictitious Jedi masters of the

57 Cintra Pemberton, Soulfaring - Celtic Pilgrimage Then and Now (Harrisburg, PA: Morehouse Publishing, 1999), I3.

58 Seán O’Duinn, 'The Cult of the Dead in Early Irish (Celtic) Spirituality', in Celtic Threads, ed. Padraigín Clancy (Dublin: Veritas, I999), 68-9.

59 Ley lines were first identified by photographer Alfred Watkins in 1925. They are presented as significant ancient alignments of monuments. One such straight line connects a number of religious sites dedicated to St Michael, among which Skellig Michael. This line is also called Apollo line. New Age theorists and activists consider that ley lines are sources of energy saturated with spiritual power.

60 'Skellig Michael, Ireland - Featured in Star War: The Force Awakens', <https://www. youtube.com/watch?v=R4nr-bKHFIQ>. [Accessed 6 May 2017].

6I 'Skellig Michael - ancient planetary portal of light - Star Wars VII Connection', <https://www.youtube.com/watch?v=aLinIo6QLZ8>. [Accessed 6 May 2017]. 
Star Wars series will also feel attracted to the island, presented in episodes 7 and 8 as the location of the first Jedi Temple and the site of an interplanetary struggle between light and darkness, an unexpected reminder of the significance of Skellig Michael since the origin. ${ }^{62}$

In I910, the island of Skellig Michael was described by George Bernard Shaw as 'part of our dream world'. ${ }^{63}$ In 2015 , J. J. Abrams, the director of Star Wars VII (The Force Awakens), chose it as a location for his film on the grounds that it was 'a miracle' from 'another time and place.' ${ }^{64}$ Yet at the same time, the Skellig Ring Drive 'has been named one of the top regions in the world for travellers in 2017'. Lonely Planet describes it as 'a spot of timeless beauty' worth seeing 'now that it's coming to prominence on the silver screen. ${ }^{65}$ It seems in fact that the preservation of heritage is more and more giving way to its interpretation as recreation. It appears that merchandization, globalization but also paradoxically conservation and the emergence of alternative spiritualities have resulted in the such instrumentalization of Skellig Michael that its integrity is now threatened. It may be time to investigate and systematically collect all traditions and legends about the Skelligs so that the wealth and meaning of their intangible heritage may be recognized. Unless this is done, they may ultimately disappear. Indeed, in the UNESCO definition 'intangible cultural heritage can only be heritage when it is recognized as such by the communities, groups or individuals that create, maintain and transmit it - without their recognition, nobody else can decide for them that a given expression or practice is their heritage. ${ }^{36}$

62 The Last Jedi, trailer, <https://www.theguardian.com/film/video/2017/apr/14/starwars-last-jedi-trailer-film-current-sequel-trilogy-video $>$. [Accessed 6 May 2017].

63 George Bernard Shaw, 'letter written from Parknasilla Hotel, Sneem, i8th September I9I0', <http://www.stefangeens.com/gbs.html>. [Accessed 6 May 2017].

64 'JJ Abrams sought authenticity of Skellig Michael', YouTube Video, <https://www. youtube.com/watch? $\mathrm{v}={ }_{\mathrm{wB}}$ 4Niuobrr4 $>$. [Accessed 6 May 2017].

65 Fáilte Ireland, 'The Skellig Ring Drive', in Celtic Times, <https://theceltictimes. com/ index.php/places-main-menu 1/the-skellig-ring-drive $>$. [Accessed 6 May 2017].

66 UNESCO, 'What is Intangible Heritage?', UNESCO website, <http://www.unesco. org/culture/ich/en/what-is-intangible-heritage-00003>. [Accessed 6 May 2017]. 
Heritage is a complex notion, as is well exemplified by the case of Sceilg Mhichíl. What appears from this example is that the present endlessly manipulates the past to suit its own interests. As a consequence, preservation necessarily goes hand in hand with alteration, reinterpretation and even destruction. Each generation reinvents the legacy it has received and adapts it to its needs. Today's paradoxical belief that there may be at the same time a sacred and economic dimension to heritage may appear as the specific contribution of our age. But Sceilg Mhichíl has been reimagined so many times since Celtic or even pre-Celtic times that human imagination itself is part of its heritage. The island has fascinated and intrigued so many generations that it might be understood as emblematic of the human mind's complexities and power. This too is our heritage. 



\section{Faith-based Tourism in Ireland and France}

Tourists' motives and motivation for undertaking travel have been widely studied by scientists and researchers, especially anthropologists, sociologists and geographers. ${ }^{1}$ Tourism, recreation and leisure studies identify travel needs and goals, monitor and predict patterns and trends at international, regional and local levels. State agencies, local authorities and the booming tourism industry try to make the most of these interdisciplinary analyses to grasp development and business opportunities, ${ }^{2}$ by working out strategic plans $s^{3}$ to respond to tourists' demands and to maximize economic and social benefits. Faith-based tourism, however, has not yet received so much attention in our growing secular societies where spirituality is sometimes looked down on, stereotyped or viewed as old-fashioned.

Of course, religion is recognized as having been the driving factor of early tourism with groups of faithful travelling to holy sites such as Rome or Jerusalem, which quickly became important religious centres, and hence an important part of the cultural landscape and the local economy. Religious-oriented journeys began with the first pilgrimages and major shrines continue to attract millions of visitors today. For many professionals, religious tourism is the new name given to pilgrimages, for it creates cash flows, employment, business prospects and boosts local economies just as sun holidays, business or wellness tourism do. Yet, this definition is not universally accepted. Some authors argue religion and tourism cannot

I See Charles R. Goeldner and Brent J. R. Ritchie, Tourism: Principles, Practices, Philosophies (Hoboken, NJ: John Wiley \& Sons Inc., 20II).

2 See John Christopher Holloway and Claire Humphreys, The Business of Tourism (Harlow: Financial Times/Prentice Hall, 2016).

3 See Nigel Evans, David Campbell and George Stonehouse, Strategic Management for Travel and Tourism (Oxford: Butterworth-Heinemann, 2003). 
be synonymous, for they are two contrasting concepts and are really diametrically opposed to one another.

According to Romain Roussel, 'A pilgrimage is a road to the inner-self [...] to a place which can help us find the meaning of our existence. [...] To be seen as a pilgrimage, a visit must be made with a devout intent. A mere tourist excursion is not enough. A pilgrimage implies veneration'. ${ }^{4}$ Conversely, tourism is a kind of escape from the self, full of entertaining attractions, wonderful landscapes or outlandish traditions. In Roussel's view, tourism would be associated with frivolity and consumerism, whereas pilgrimages evoke solemnity and commitment.

Dean Mac Cannel, in an essay entitled The Tourist, A New Theory of Leisure Class, expresses reservations about this dichotomy. To him, modern sightseeing is characterized by a quest for authenticity, equivalent to the traditional experience of the Sacred:

Modern international sightseeing has a moral structure, a collective sense that certain sights must be seen. Guided tours are extensive ceremonial agendas involving long strings of obligatory rites. If one goes to Europe, one 'must see' Paris, if one goes to Paris, one must see Notre-Dame, the Eiffel Tower, the Louvre. [...] There are quite literally millions of tourists who have spent their savings to make the pilgrimage to see these sights $[\ldots]$ with all their hearts. ${ }^{5}$

The dynamics of religious tourism have radically changed over the past few decades. ${ }^{6}$ This niche market is no longer limited to traditional destinations. Conserving and managing cultural religious heritage has become a

'Le pèlerinage est un chemin vers le Moi profond, [...] vers quelque lieu [...] qui nous aide à retrouver le sens de notre expérience vitale. [...] Pour qu'une visite puisse être considérée comme pèlerinage, il faut qu'elle soit faite dans une intention dévotieuse. [...] Une excursion touristique n'y suffit point. Le pèlerinage requiert une volonté de vénération', in Romain Roussel, Les pèlerinages (Paris: Presses Universitaires de France, 1972), 72. My translation.

5 Dean Mac Cannel, The Tourist, a New Theory of Leisure Class (Berkeley: University of California Press, 1976), 42-3.

6 Marie-Hélène Chevrier, 'Pèlerinage, développement urbain et mondialisation, l'exemple de Lourdes', Géoconfluences, 2016. Available: <http:// geoconfluences.ens-lyon.fr/informations-scientifiques/dossiers-thematiques/ 
challenging issue that is being taken up by most European countries. This chapter will compare and contrast the decisions and measures taken in France and in Ireland to boost religious tourism. Indeed, both countries have magnificent religious heritage sites and works of art, along with a myriad of religious traditions and festivals. However, their secular perspectives on faith-based tourism management are far different. We will examine the way each country perceives the specificities of this niche sector and discuss this impacts marketing communication actions and performance.

Religious tourism used to reach practising believers, diocesan groups and religious congregations. It has developed as a specific form of cultural heritage tourism and now reaches individuals eager for knowledge and unusual experience, who are motivated by personal aspirations: ${ }^{7}$

Faith tourism has entered a new era, $[. .$.$] not driven by pilgrimages, but by mission-$ ary travel, faith-based cruising, faith-based attractions, leisure vacations, adventure trips, conferences and so on. These trips appeal to all ages and all demographics. Faith tourism is now enjoyed by, taken by, purchased by all age groups - from youth to baby boomers to retired folks - all on equal levels. ${ }^{8}$

Tourism is seen by the Roman Catholic Church as 'one of the new Areopaguses of evangelization, [...] where Christians are called to live their faith and their missionary vocation.' The Sacred Congregation for the Clergy recalled the community's mission to 'serve people on their

fait-religieux-et-construction-de-l-espace/corpus-documentaire/pelerinage-lourdes $>$. [Accessed I8 December 2017].

7 Réseau de veille en tourisme - Chaire de tourisme Transat, 'Le tourisme religieux: portrait, profil du voyageur et potentiel de développement', ESG UQAM, March $201 I$. Available: <http://bel.uqtr.ca/ı852/I/Le-tourisme-religieux_final.pdf >.[Accessed I8 December 2017]

8 Jena Tesse Fox, 'Religious Tourism Enters a New Era', Travel Agent Central, I September 2008. Available: <https://www.travelagentcentral.com/tours/religioustourism-enters-a-new-era-0>. [Accessed I8 December 2017].

Pontifical Council for the Pastoral Care of Migrants and Itinerant Peoples, Guidelines for the Pastoral Care of Tourism, Rome, 29 June 200I. Available: <http://www.vatican.va/roman_curia/pontifical_councils/migrants/documents/rc_pc_migrants_ doc_200107II_pastorale-turismo_en.html>. [Accessed 22 December 2017]. 
travels for recreation. ${ }^{10}$ Local Churches are supposed to foster and organize pastoral work among tourists in a ministry of welcome likely to meet each visitor's spiritual and educational needs. This chapter will seek to assess the extent to which the pastoral guidelines advocated by the Vatican have been implemented by the Church in France and in Ireland, focusing on cultural religious heritage as a tool to promote shared Christian values, to generate or renew a sense of belonging.

\section{Faith-based Tourism Development Strategies in France}

France is the world's leading tourism destination with more than 85 million visitors in $2015 .{ }^{11}$ More than 89 million tourists are expected in $2017 .{ }^{12}$ Twenty million of them come to France with a religious interest, which represents 44 per cent of its cultural tourism according to the United Nations World Tourism Organization. Thirteen million people a year visit Notre-Dame. ${ }^{13}$ Sacré-Cœur Basilica receives io million tourists, ${ }^{14}$ while

Io Sacred Congregation for the Clergy, General Directory for the Pastoral Ministry to Tourism, Rome, 1969. Available: <www.vatican.va/roman_curia/congregations/ cclergy/documents/rc_con_cclergy_doc_19690429_ministry-tourism_en.html>. [Accessed 20 December 2017].

II Valls III Government, 'France remains the world's leading tourist destination', 2016. Available: www.gouvernement.fr/en/france-remains-the-world-s-leading-touristdestination. [Accessed: I8 December 2017]

I2 UNWTO World Tourism Barometer, 'International tourism on track for a record year', 6 November 2017, Available: <http://media.unwto.org/press-release/2017-II-06/ international-tourism-track-record-year $>$. [Accessed I8 December 2017]

I3 'Notre-Dame de Paris: la cathédrale en chiffres' Available: <http://www. notredamedeparis.fr/la-cathedrale/les-informations-insolites/la-cathedrale-enchiffres/>. [Accessed: I8 December 2017].

I4 Office du Tourisme et des Congrès de Paris, 'Fréquentation culturelle 2016 à Paris: une affluence limitée par un contexte touristique difficile', 26 June 2017. Available: $<$ https://presse.parisinfo.com/actualites/communiques-de-presse/frequentationculturelle>. [Accessed I8 December 2017]. 
the sanctuary of Lourdes welcomes 7 million people on average. Some spiritual places such as Mont-Saint-Michel, Rocamadour or the Way of St James have never been so popular. ${ }^{15}$ They attract pilgrims and tourists who feel the need to revitalize themselves. In fact, the proportion of nonbelievers has developed significantly. They are history buffs or art lovers, people who are willing to spend their leisure time away from the consumer society in places conducive to human contact.

The rise of spiritual tourism in France can be explained by the diversity of the religious sites open to visitors, with 163 sanctuaries and 50,000 religious buildings, I0,000 of them being classified as 'historical monuments' or listed as UNESCO World heritage sites. ${ }^{16}$ France has long adopted a process of registering religious sites, monuments and works of art as part of a national heritage and has launched a public policy for heritage enhancement. It has been involved in their conservation-restoration, in their protection and care. ${ }^{17}$ The Department for Tourism in France has clearly identified the economic potential of these sites and the financial windfall they can achieve as levers for local development and national growth. Atout France, ${ }^{18}$ a State agency, has been given the mission to strengthen the attractiveness of the country and the competitiveness of its tourism industry. Thanks to its thirty-two offices in twenty-seven countries and its close collaboration with the Embassies abroad, it supports companies in their international development and organizes promotional operations.

Isabelle De Foucault, 'La France séduit les adeptes du tourisme religieux', Le Figaro, 7 April 2012. Available: <http://www.lefigaro.fr/conso/2012/04/06/0500720120406ARTFIG00697-la-france-seduit-les-adeptes-du-tourisme-religieux.php >. [Accessed I8 December 2017].

I6 Joséphine Bataille, 'Le tourisme spirituel, l'autre façon de visiter la France', La Vie, 9 July 20I2. Available: <http://www.lavie.fr/spiritualite/le-tourisme-spirituel-l-autrefacon-de-visiter-la-france-09-07-2012-29152_22.php $>$. [Accessed 20 December 2017].

17 Observatoire du Patrimoine religieux Available: <http://www.patrimoine-religieux. $\mathrm{fr} / \mathrm{m}>$. [Accessed 20 December 2017]. Ministère de la Culture, Direction générale des patrimoines Available: <http://www.culturecommunication.gouv.fr/Nousconnaitre/Organisation/Directions-d-administration-centrale/La-directiongenerale-des-patrimoines $>$. [Accessed 20 December 2017]. Atout France. Available: <http://atout-france.fr/>. [Accessed 20 December 2017]. 
The agency created a Cluster on Tourism and Spirituality ${ }^{19}$ made up of thirty-one professionals whose offers are related to spirituality, pilgrimages and cultural places, divided into four categories: 'Sites or sanctuaries', 'Institutional bodies, associations, groups of professionals or establishments', 'Tour operators and hauliers' and 'Accommodation services'. A marketing strategy has been put in place to position France as the ideal destination for spiritual tourism by developing its offer and boosting the reputation of less well-known religious sites. Atout France supplies details about spiritual events, festivals and meetings. It enhances religious heritage diversity and designs innovative itinerant tourism products as a complementary offer on spiritual trails. The cluster has been leading several promotional activities at domestic and international levels, more specifically in European markets (Italy, Spain and Poland) and in distant and emerging countries with large Catholic communities (USA, Brazil, India, Korea, the Philippines/Indonesia and Singapore). The operations conducted aim at increasing visibility thanks to international communication campaigns to highlight the assets of France as a destination for religious heritage itineraries and faith-based tourism..$^{20}$ They target both professional partners and the general public - believers and non-believers, seniors and families through an active digital strategy: a user-friendly website www.france. fr and updated pages on social networks (I.5 million fans on Facebook).

The method seems to be paying off and new trends in spiritual tourism can now be observed. Indeed, if French people enjoy Marian shrines, many foreigners are more attracted by sanctuaries dedicated to Christ, which permit a more harmonious and balanced spatial distribution of people and activities. For instance, according to Atout France, in $2016 \mathrm{Le}$ Puy-en-Velay, a Marian town and one of the starting points of the Way of St James, welcomed hundreds of visitors of sixty-two different nationalities to its cathedral. In Paray-Le-Monial, in Burgundy, visitor numbers increased by 12 per cent in 2016 compared to 2015 , a third of whom were made up tourisme-et-spiritualite $>$. [Accessed 20 December 2017].

20 France - Spiritualité. Available: <http://be.france.fr/fr/spiritualite>. [Accessed: 20 December 2017]. 
of foreigners, with a steady increase of nationals from emerging countries, mostly Filipinos and Indonesians. New profiles of visitors were also identified in Lisieux. According to the Tourist Office, ten years ago Brazilian tourists were thin on the ground, but today they rank second behind the Americans. Chinese visitors are relative new-comers to this sector but their interest in the site has been growing: ten Chinese groups in 2014, fifty-two groups in 2016 with an average of forty-five people. ${ }^{21}$ China is officially an atheist state, but its population is multi-denominational; 2.6 per cent are Christians, which represents around 35 million people. Domestic and international religious tourism is on the rise and tour operators tailor religious heritage itineraries to meet new requirements. ${ }^{22}$ Travelling abroad for leisure is a recent trend for Chinese tourists who usually opt for fully packaged tours abroad. Most of them are educated city-dwellers who look for meaningful travel experiences, eager to visit famous historical places, cultural and religious heritage sites and to connect with the locals, especially in safe cities and small towns, so as to learn about traditions and customs. ${ }^{23}$ Their market profile is to be taken into account to suit this potentially huge visitor and customer base.

French Religious Travel agencies receive more and more requests for religious heritage tours and spiritual holidays, a phenomenon Jacques Gayan, manager of Ichtus Voyage, a reputed agency, identifies as 'a contemporary call, a need to breathe', while the Director of Routes Bibliques, Jean-Pierre Morin, believes it corresponds to a spiritual quest. He describes his clientele as God seekers, people who believe in God and look for him on a daily basis, and as tourists who aspire to live better lives by following

2I Catherine Heuzé, 'Le tourisme spirituel en pleine ascension', Aleteia, is April 2017. Available: <https://fr.aleteia.org/2017/04/15/le-tourisme-spirituel-en-pleine-ascension/> [Accessed: 20 December 2017].

22 Shan Juan, 'Growing Interest in Religious Tourism', China Daily, I9 November 2010, Available: <http://www.chinadaily.com.cn/china/20IO-II/I9/ content_II574548. htm $>$. [Accessed 20 December 2017].

23 Eduardo Santander, 'Chinese and Brazilian Outbound Tourism Markets and Netnography', 7th UNWTO/PATA Forum on Tourism Trends and Outlook, 2013, Available: <http://cf.cdn.unwto.org/sites/all/files/docpdf/oct22paneli40oI60opresentationeduardosantander.pdf $>$. [Accessed 20 December 2017]. 
a spiritual path. For them, religious heritage tourism is an inspiring opportunity to rediscover their own traditions and to increase their knowledge of other cultures. ${ }^{24}$ Two thirds of the clients are elderly but more and more groups of young people aged eighteen to twenty-five take part in what they perceive as a spiritual adventure, as a time for mutual understanding and introspection. Religious tourism also has a favourable impact on the guidebook industry. As an example, since 2004, Le Petit Futé has released successful books on spiritual trails in France ${ }^{25}$ and Europe, ${ }^{26}$ because of 'an increase in the rate of visits to spiritual sites and of requests for accommodations in these same places'. ${ }^{27}$

\section{Religious Tourism in Ireland: An Underexploited Market}

Ireland received 8 million visitors in 2015 , and 10.3 million in 2016. Approximately 40 per cent of them come from Great Britain, i 8 per cent from the United States and 35 per cent from Europe. ${ }^{28}$ Christianity has

24 Anne-Lise Defrance, 'Le tourisme religieux attire de nouveaux adeptes', Le Monde, is August 2005. Available: <http://www.lemonde.fr/societe/article/2005/08/15/le-tourisme-religieux-attire-de-nouveaux-adeptes6801823224. html\#SgCJowoHboTBMKUk.99>. [Accessed 20 December 2017].

25 Laure Jaulerry, Pascaline Ferlin, Véronique Hunsiger, Jean-Paul Labourdette, Séjours spirituels en France (Paris: Nouvelles éditions de l'université - Le Petit Futé, 2004).

26 Dominique Auzias, Jean-Paul Labourdette, Séjours spirituels en Europe (Paris: Nouvelles Editions de l'université - Le Petit Futé, 2005).

27 'Sa parution résultait d'un constat récurrent de la part de l'ensemble de nos auteurs dans leurs enquêtes: un accroissement du taux de visite des sites spirituels, mais aussi de demandes d'hébergement dans ces mêmes lieux', in Atout France, 'Lettre de veille internationale', April 2016. Available: <http://atout-france.fr/sites/default/files/imce/lettredeveilleinternationaleavril20160.pdf $>$. [Accessed 20 December 2017]. My translation.

28 Tourism Ireland, 'Isle of Ireland Overseas Tourism Performance - 2016 Facts and Figures', Dublin, 20 July 2017. Available: <https://www.tourismireland.com/ TourismIreland/media/Tourism-Ireland/Press\%20Releases/Press\%2oReleases\%20 2017/Facts-and-Figures-2016.pdf ? ext=.pdf $>$. [Accessed 20 December 2017] . 
played an important part in shaping Irish history and culture. Ireland is known worldwide as the land of Saints and Scholars. The country seems to be an ideal destination for religion-based holidays given the concentration of religious shrines and popular sites such as Glendalough or Clonmacnoise.

Faith-based travels have been increasing as a form of special-interest tourism. However, even if it contributes to attracting visitors, no specific promotion or communication campaigns have been launched abroad by the Irish Department for Tourism, because these religious places and spiritual products are thought to be best promoted as cultural heritage tourism. Thus, on Discoverireland.com, a section named 'Arts, Culture and Heritage' lists seventeen Christian pilgrimage sites, Christian or Zen spiritual trails. ${ }^{29}$ The website only provides the user with basic information and, surprisingly enough, offers a very limited view of Ireland's religious heritage landscape. Tourism Ireland says it does target faith-based travellers with its promotional programme aimed at a wider 'sightseer and culture seeker' audience, ${ }^{30}$ but only one promotional business event was organized in 2012 when ten leading Italian tour operators specialized in religious tourism were invited to visit Ireland. ${ }^{31}$

Ireland has an extensive and varied religious heritage, many unique spiritual attractions to offer, but the domestic religious tourism sector needs to be better organized. 'Celtic spirituality in Ireland has to be properly highlighted', ${ }^{32}$ for people to want to explore Irish ancient and contemporary religious sites. Indeed, when foreign people think of planning a faith-based

29 DiscoverIreland - Arts, Culture and Heritage. Available: <https://www.discoverireland.ie/CMSPages/PortalTemplate.aspx ?aliaspath=\%2FSearch\%2FResults\&cat $\mathrm{id}=10083 \&$ lcid $=2 \&$ countyid $=879 \&$ reftype $=1>$. [Accessed 20 December 2017 $]$.

30 Fáilte Ireland, 'Attract cultural tourists - Heritage tourism marketing'. Available: $<$ http://www.failteireland.ie/Supports/Develop-your-tourism-enterprise/AttractCultural-Tourists.aspx $>$. [Accessed 20 December 2017].

3I Tourism Ireland, 'Italian tour operators on trail of St Patrick', 8 March 20I2. Available: <https://www.tourismireland.com/Press-Releases/2012/March/ Italian-touroperators-on-trail-of-St-Patrick>. [Accessed 20 December 2017].

32 'We have a rich cultural heritage at our doorstep', The Independent Supplement, 25 March 20I2. Available: <https://www.independent.ie/irish-news/we-have-a-richreligious-heritage-on-our-doorstep-26857129.html>. [Accessed 20 December 2017]. 
trip, Rome or Israel are more likely with to spring to mind than Ireland. Most of the promotion abroad is around natural landscapes, golfing, wellness holidays, Guinness, music and pubs which, of course, is quite effective but Fáilte Ireland, the National Tourism Development Authority, seems to neglect faith-based aspects and does not invest enough money in this area.

Yet, thousands of religious tourists are estimated to arrive from the United States, Chile, the United Kingdom, Europe, Malaysia, the Philippines or Canada to know more about Ireland's religious heritage, famous monastic sites, high crosses, to admire the Book of Kells or to visit the shrine at Knock. Cultural tourism attracts to Ireland 3.5 million overseas visitors on average, ${ }^{33}$ but no precise official figures can be given concerning religious or spiritual tourism. Foreign travellers' great interest in Mass rocks symbolizing how the Irish struggled to hold on to their faith in Penal times remains underexploited. Many foreign travel agencies consider 'the Irish religious tourism sector is just ticking over' ${ }^{34}$ Faith-based and religious heritage tourism are identified as resilient sectors, crucial to sustainable development and growth in host communities. They can result in long-lasting socio-economic benefits; contribute to the cohesion and empowerment of the locals. ${ }^{35}$ Their multifaceted potential is underestimated by the Irish Tourism Board, which should play a much more active role in improving partnership synergy among stakeholders and in supporting community-driven projects. Indeed, 'local communities are [...] vital in ensuring the sustainability of tourism through the provision of locally-embedded activities, and tourism supports the local community Glen Hooper (ed.), Heritage and Tourism in Britain and Ireland (London: Palgrave Macmillan, 2016), is8.

34 Desmond Deignan, Managing Director of Mancunia Travel in Manchester quoted in 'We have a rich cultural heritage at our doorstep', The Independent Supplement, 25 March 20I2. Available: <https://www.independent.ie/irish-news/we-have-a-richreligious-heritage-on-our-doorstep-26857129.html>. [Accessed 20 December 2017]. Taleb Rifai, 'Breaking down boundaries: The Opportunities and Challenges of Religious Tourism', MMNieuws, December 2016. Available: www.mmnieuws.nl/ article/breaking-down-boundaries-the-opportunities-and-challenges-of-religioustourism/. [Accessed 20 December 2017]. 
economically. In this sense there is a sustainable triangular relationship between tourism, culture and community.'. ${ }^{36}$

Contrary to the Irish state, domestic and foreign travel agencies and tour operators have spotted the growth opportunities of this very lucrative niche. According to these professionals, faith-based travellers usually stay in Ireland for up to ten nights, visiting major religious heritage sites such as Lough Derg and Glendalough, as well as Newgrange and the Aran Islands. They like to have time for prayer and reflection and Mass and they enjoy Irish culture and interaction with the local community. ${ }^{37}$ Joe Walsh Tours, a well-known Irish travel operator, has developed new faith-based itineraries and Christian heritage programmes which they market abroad. ${ }^{38}$ They work closely with the Centre for Celtic Spirituality in Armagh ${ }^{39}$ in order to provide tourists with experts and lecturers giving talks on $\mathrm{St}$ Bridget or St Patrick during guided tours. Many of these tourists are of Irish descent and want to go to very specific places, such as Ballintubber Abbey, Croagh Patrick, Dublin Pro-Cathedral, or Drogheda to venerate the head of Blessed Oliver Plunket in St Peter's Church. Knock Marian Shrine is also enjoyed as a top religious tourism attraction. The growing interest in the pilgrimage in the United States and the success of Knock's 'Witness to Hope' marketing project ${ }^{40}$ even led Ireland West Airport to

36 Greg Richards, 'General Framework for a Triangular Partnership: Tourism, Culture and Community', in World Tourism Organisation, Tourism and Culture Partnership in Peru: Models for Collaboration between Tourism, Culture and Community (Madrid: UNWTO, 2016), i7.

Kerry Ward, Managing Director of Galway Company Celtic Footstep quoted in 'We have a rich cultural heritage at our doorstep', The Independent Supplement, 25 March 20I2. Available: <https://www.independent.ie/irish-news/we-have-a-richreligious-heritage-on-our-doorstep-26857129.html>. [Accessed 22 December 2017]. Joe Walsh Tours - In the Footsteps of Irish Saints. Available: <http://www. joewalshtours.ie/section/tours-of-ireland-in-the-footsteps-of-irish-saints $>$. [Accessed 22 December 2017]. Centre for Irish Spirituality website. Available: <http://www.celtic-spirituality. net/>. [Accessed 22 December 2017].

40 Knock Shrine - Witness to Hope. Available: <https://www.knockshrine.ie/ witnesstohope/>. [Accessed 22 December 2017]. 
schedule special charter flights from New York City in 2015 and from Boston in 2016 for diocesan pilgrimages, with more regular transatlantic flights in prospect. ${ }^{41}$

\section{Welcoming Tourists and Pilgrims: An Evangelical Mission}

Initiatives are also taken in some sanctuaries to meet pilgrims' new demands, as in Lough Derg, Co. Donegal, a penitential pilgrimage site where Saint Patrick is said to have fasted and prayed for forty days. ${ }^{42}$ The traditional three-day pilgrimage on Station Island, also known as St Patrick's Purgatory, is physically demanding with constant prayers, frugal meals and little sleep. It is perceived as a deep religious experience for Irish Catholic pilgrims, mostly driven by the desire to have their sins forgiven or their prayers answered. The motivation of the pilgrims varies a lot and according to Deborah Maxell, the Lough Derg manager, new kinds of people embark on the pilgrimage as a spiritual retreat and quest for well-being in a place where they can fulfil their need for spirituality and traditions: 'Those who undertake it find that it purges both body and soul and makes them more appreciative of the comforts of western civilization'. ${ }^{43}$ They come for a time out, seeking to slow down and take stock as if it were 'a detox for soul and body', ${ }^{44}$ a curative treatment against

4I Jane O'Flaherty, 'Ireland West Knock Airport: New flight from Boston to start this Summer', The Independent, 25 January 2016. Available: < https://www.independent. ie/business/irish/ireland-west-knock-airport-new-flight-from-boston-to-start-thissummer-34393456.html>. [Accessed 22 December 2017].

42 Lough Derg website. Available: <https://www.loughderg.org/>. [Accessed 22 December 2017].

43 Cited by Ian Bradley, Pilgrimage, A Spiritual and Cultural Journey (Oxford: Lion Hudson, 2009), 2 I.

44 'Pilgrims in retreat from progress: God and the Celtic Tiger', The Independent, Io August 2006, Available: <http://www.independent.co.uk/news/world/europe/ pilgrims-in-retreat-from-progress $>$. [Accessed 22 December 2017]. 
stress and anxiety, a moment when they can 'discover [their] hidden strengths and rediscover what really matters in life', ${ }^{45}$ as is claimed on the Lough Derg website.

In the 1990s, three-day pilgrimages became less popular, so the site decided to adapt its 'products', offering new services such as youth and school retreats, but more interestingly, one-day retreats with 'softer' rituals, with shoes on and lunch served. Lough Derg presents this shorter experience as the opportunity to take a detour from daily routine, 'to discover the difference a day on the sacred Island can make, ${ }^{46}$ which may sound more like a tourist experience in an unfamiliar setting.

However, it is undeniable that one-day retreats allow for 'a liminal activity [which] involves an interruption from ordinary life, deliberately casting off into the unknown and crossing the boundary between the routine and familiar and the unpredictable and strange'. ${ }^{47}$ Through a slow and quiet religious influence, they may give the Church the chance to turn tourists into pilgrims, to revive their faith, to create or recreate a link with non-believers or lapsed Catholics. Indeed, as Maciej Ostrowski points out:

We may expect that it would have been more difficult to invite such persons on a pilgrimage with a strictly religious programme. It might simply discourage some of them. It is easier to attract people to an ordinary tourist trip even with religious

'The Pilgrimage is all about letting go! From the moment you reach the car park at Lough Derg you begin the process of letting go and slowing down. The Island is a mobile free zone and this immediately removes us from our fast-paced modern lives. Lough Derg is a place of welcome ... Come as you are, friend or stranger, young or old, searching or a peace, in joy or in sadness; come to the sanctuary of St Patrick a shrine of prayer and deep awakening to the presence of God. [...] Without shoes and sleep and little food in our stomachs we are confronted with the essential aspects of life, everything else is stripped away and we can often discover our hidden strengths and rediscover what really matters in life', in Lough Derg - Three-day Pilgrimage. Available: <https://www.loughderg.org/three-day-pilgrimage-season/>. [Accessed 22 December 2017].

46 Lough Derg - one-day retreats. Available: <https://www.loughderg.org/one-dayretreats/>. [Accessed: 22 December 2017].

Ian Bradley, Pilgrimage, A Spiritual and Cultural Journey, 21. 
accents in its itinerary. A skilfully conducted excursion $[. .$.$] may create numerous$ opportunities for evangelical testimonies. ${ }^{48}$

Besides, while visiting churches, shrines and sanctuaries, tourists experience their historical and cultural dimensions and may feel the emotional side of Catholicism in these sacred places that are seen as meeting points between Heaven and Earth, as sacred spaces for dialogue and soul healing. In that way, faith-based tourism allows for the enhancement and the dissemination of fundamental values through human encounters at the core of the Church's living heritage. According to Jacky Cordonnier, people 'have become allergic to dogmatism and legalism. [They] do not want a doctrine, but an experience. [They] don't look for theologians but witnesses, people who believe and speak of a religious experience'. ${ }^{49}$

Likewise, in Knock Marian shrine, one of the most visited locations in Ireland with I.5 million pilgrims and tourists each year, guided tours are available, ${ }^{50}$ and a museum is dedicated to the Apparition in 1879 . It describes how fifteen local Roman Catholic witnesses claimed to have seen the Lamb of God, the Virgin Mary, St Joseph and St John the Evangelist. Visitors can read original letters and listen to the testimony of pilgrims describing how they were miraculously cured. An educational and entertaining storytelling strategy, inspired by marketing techniques, ${ }^{51}$ offers deeper understanding. Visitors 'share in the experiences of the

48 Maciej Ostrowski, 'Pilgrimages or Religious Tourism?', in Antoni Jackowski, ed., Selected Research Problems in the Geography of Pilgrimage, Peregrinus Cracoviensis, IO, 2000. Available: <http://www.geo.uj.edu.pl/publikacje, 0000 I5?\&lang=ı >. [Accessed 22 December 2017].

49 'Notre contemporain est devenu en quelque sorte allergique au dogmatisme et au jurisme de nos Eglises. Il ne demande pas une doctrine mais une expérience. Il cherche non point des théologiens mais des témoins, des gens qui y croient et parlent par expérience religieuse', in Jacky Cordonnier, Religions et croyances actuelles (Lyon: Chroniques sociales, 2000), 209. My translation.

so Knock Shrine - Guided tours Available: <https://www.knockshrine.ie/guidedtours/ >. [Accessed 22 December 2017].

5I Jennifer Zottola, 'Why Storytelling in Marketing is a Powerful Strategy', Stern Strategy Group Insights, I 4 September 2016. Available: <https://insights.sternstrategy.com/ storytelling-marketing-powerful-strategy/>. [Accessed 22 December 2017]. 
millions of pilgrims that have visited through the years and learn of the ordinary people who witnessed the Apparition, an event that changed their lives and the village of Knock forever. ${ }^{52}$ Tourists are exposed to a legacy of unwavering beliefs through an emotional immersion, which can awake or strengthen their faith. They are invited to become in the Knock pilgrimage narrative by telling their own story. They are called to witness, to share their own Christian experience. Doing so, they play an active part in the evangelization process advocated by the Roman Catholic Church:

Discipleship is rooted in human experience. It is through human experience that one enters into a dialogue with modern culture. The human experience provides the 'sensible signs' that help us come to know ourselves, one another, and God. It is through common human experiences that the Word of God is revealed to us. [...] Catechetical foundations are necessary for creating a culture of witness that testifies to the transformative power of the Gospel. ${ }^{53}$

Some local Irish priests also see religious heritage tourism as an opportunity to complete their evangelical mission. For instance, Father Frank Fahey who ministers at Balintubber Abbey in Co. Mayo, the starting point of an ancient path to Croagh Patrick, ${ }^{54}$ welcomes and guides pilgrims, tourists and hikers. The national revitalization of medieval penitential paths, based on a plan to renovate, maintain and protect rural Ireland's natural and religious heritage, incites the locals to rediscover their Christian roots. These Irish caminos are no mere physical landmarks but bearers of intangible heritage. They play a part in passing down cultural and spiritual richness to posterity. This heritage enhancement programme also gives the Church the chance to convert modern walkers and

52 Knock Shrine - Museum.

53 Committee on Evangelization and Catechesis, Disciples Called to Witness, The New Evangelization (Washington, DC: United States Conference of Catholic Bishops, 2013), I3-I4.

54 Áine Ryan, 'The Abbey That Refused To Die', Mayo News, i9 July 2016. Available: <http://www.mayonews.ie/features/28200-the-abbey-that-refused-to-die >. [Accessed 22 December 2017]. 
to revive their faith, as hundreds of Irish people now retrace the steps of their medieval forefathers on domestic pilgrimage paths, undertaking a physical, emotional or spiritual journey. Father Fahey tries to make people acknowledge and experience the sacred dimension of a trail they may at first have approached as a mere walking tour. He invites those who are passing through to take part in Mass and prayer or to share a friendly moment with other travellers. By conveying a Christian meaning, he prevents the 'trivialization of the site'," and contributes to emphasizing both the living spirituality of his Abbey and the living nature of Catholic traditions.

Such initiatives correspond to the directives published by the Vatican for the Pastoral Care of Tourism, ${ }^{56}$ but are launched only on a local level. The Conference of the Irish Bishops has not yet organized a national project to reach Irish and foreign people on their tourist path. The hierarchy has not generalized good pastoral practice and diocesan actions are taking a long time to be set up.

In November 2016, Pope Francis officially announced his visit to Ireland in August 2018 for the World Meeting of Families, promoted by the Holy See Dicastery for Laiety, Family and Life, and organised in Dublin. ${ }^{57}$ The gathering drew thousands of pilgrims and tourists to the country. Parishes had to satisfy their spiritual needs and to respond to specific demands. The Catholic Church in Ireland felt the need to instil a spirit of welcome and to implement the pastoral guidelines advocated by the Holy See since 1969 in the Directory Peregrinans in terra. ${ }^{58}$ The

Daniel Levi, Sara Kocher, 'Understanding Tourism at Heritage Religious Sites', Focus: Vol. 6: Iss. I, Article 6, 2009. Available: <http://digitalcommons.calpoly.edu/focus/ vol6/issi/6>. [Accessed 22 December 2017].

56 Pontifical Council for the Pastoral Care of Migrants and Itinerant Peoples, Guidelines for the Pastoral Care of Tourism, Rome, 29 June $200 \mathrm{I}$.

57 Kevin Doyle, 'Pope Francis confirms he will visit Ireland in 2018', The Independent, 28 November 2016. Available: <https://www.independent.ie/irish-news/ pope-francis-confirms-he-will-visit-ireland-in-2018-35250215.html>. [Accessed 22 December 2017].

58 Congregation for the Clergy, General Directory for the Pastoral Care of Tourism, Rome, 30 April 1969. 
Irish Church made the most of this unique event to enhance its cultural heritage as a vehicle of fundamental beliefs and values. It may have fostered dialogue between faith and culture so as to help pilgrims explore their religious roots and offer tourists a spiritual experience.

The efforts made by the Roman Catholic Church in France could be used as an example for future developments. Indeed, bishops, priests, religious and lay people have been engaged in a creative pastoral task to fill tourism with Christian meaning, in accordance with the Vatican's directives on tourism and hospitality:

Tourism [...] represents a billion opportunities for the Church's evangelizing mission. [...] It is essential for the Church to go forth and be close to travellers in order to offer an appropriate and individual answer to their inner search. By opening her heart to others, the Church makes a more authentic encounter with God possible. With this goal, hospitality by the parish communities and the religious formation of tourist personnel should be enhanced. ${ }^{59}$

For many ecclesial communities in France, the tourism phenomenon has become an opportunity for evangelization. ${ }^{60}$ The dioceses have provided themselves with suitable pastoral structures to welcome pilgrims and 'accidental' tourists who visit a church or a sanctuary with religious or educational motives, interested in discovering a rich cultural and religious heritage. ${ }^{61}$ Priests are encouraged to learn foreign languages to be able to celebrate Mass, to administer the Sacrament of Penance or to post announcements in the languages most familiar to tourists. Parish communities are trained to welcome and guide visitors. Informative booklets on parishes are available

Pontifical Council for the Pastoral Care of Migrants and Itinerant People, 'Message World Tourism Day 20I5 - One billion tourists, one billion opportunities', Vatican City, 24 June 20I5. Available: <https://zenit.org/articles/world-tourism-daymessage/ $>$. [Accessed I8 December 2017].

60 François-Xavier Maigre, 'Les touristes ont tous une attente profonde même s'ils ne l'expriment pas tout de suite', La Croix, 24 May 2008.

6I Conférence des Evêques de France, 'La pastorale du tourisme et des loisirs: Donner une âme au temps libre', 7 August 2017. Available: <http://eglise.catholique.fr/ actualites/4426II-pastorale-tourisme-loisirs-donner-ame-temps-libre/>. [Accessed I8 December 20I7]. 
in churches, tourist offices and on the Internet. A national catechesis on 'Free Time and Tourism', has been launched to deepen the tourists' faith. ${ }^{62}$ Tourism is seen as a time for encounters, for dialogue, as a potential vehicle of faith. Parish team members in charge of guided tours present and explain the historical and artistic specificities of the edifice but their main mission is to underline the sacred dimension of their Church and its communal nature. ${ }^{63}$ By so doing, parishioners witness to their faith though cultural heritage and are involved in soft proselytism. They interpret sites, buildings and works of arts through the lens of Catholic Doctrine with a clearly stated objective: to evangelize tourists. Their goal is to convey a Christian message, to emphasize the living spiritual identity of their Church that secular societies and States, through cultural heritage policies, tend to value only for architectural or artistic treasures, in a materialistic approach, as buildings of historical interest, as monuments, museums or memorials:

On his way, a tourist visits many places connected with religion. The point is not only for him to consider them as such. [...] There is more to it, that is the acknowledgement that the sacred is present in that place. [...] It is the belief that the place is still the centre of religious life and not only an object worth admiring because of the beauty of the architecture, the picturesque beauty of its location [...]. The point is for the tourist to enter the realms of this sacrum to be more than an external observer - to become a participant in the mystery. ${ }^{64}$

Paul VI famously said that 'the Church exists in order to evangelise, that is, to preach and teach, to be the channel of the gift of grace'. ${ }^{65}$ Pope Francis

62 Conférence des Evêques de France, 'S'engager dans la société - Pastorale du tourisme'. Available: $<$ http://eglise.catholique.fr/sengager-dans-la-societe/patrimoine-et-artsacre/pastorale-du-tourisme/>. [Accessed I8 December 2017].

63 Laetitia Drevet, 'Pastorale du tourisme: comment l'Église accueille les visiteurs de lieux de culte', La Croix, 19 June 2017. Available: <https://www.la-croix.com/ Religion/Catholicisme/Pastorale-tourisme-comment-IEglise-accueille-visiteurslieux-culte-2017-06-19-1200856285>. [Accessed I8 December 2017].

64 Ostrowski, 'Pilgrimages or Religious Tourism?'

65 Paul VI, Evangelii Nuntandi, Rome, i8 August 1975. Available: <http://w2.vatican. va/content/paul-vi/en/apost_exhortations/documents/hf_p-vi_exh_1975I208_ evangelii-nuntiandi.html >. [Accessed I8 December 2017]. 
recalled the importance of evangelization for the transmission of faith to renew the Church and make it relevant in the twenty-first century. ${ }^{66}$ The Roman Catholic Church in Ireland should set up innovative pastoral plans and structures to respond to contemporary needs and adapt the proclamation of the Gospel to a changing world with new ardor, methods and expression. The Church's role or mission is to foster understanding and respect, to turn tourists into pilgrims.

\section{Conclusion}

This chapter has underlined the contrast between the way France and Ireland deal with religious heritage as a tourist attraction. France has adopted an active and creative approach that Ireland could use as a model for future development. Indeed, the French Department for Tourism provides good practice guidance and supports close partnerships between decision-makers, tourism stakeholders and religious authorities. Religious heritage has been identified as a driver of national and local economic dynamism, social inclusion and sustainability. To fully exploit the assets of religious heritage, Ireland should identify faith-based and religious tourism as a distinct market and draw up specific resource management strategies.

Tourism also permits religious communities to witness to their faith. According to the Vatican, it gives Catholics the opportunity to complete their evangelical mission. By welcoming tourists and visitors, the faithful can turn their churches into spaces of cultural dialogue and human

66 'I wish to encourage the Christian faithful to embark upon a new chapter of evangelization marked by this joy, while pointing out new paths for the Church's journey in years to come', in Francis I, Evangelii Gaudium, Rome, 24 November 2013. Available: <http://w2.vatican.va/content/francesco/en/apost_exhortations/documents/ papa-francesco_esortazione-ap_20131124_evangelii-gaudium.html>. [Accessed I8 December 2017]. 
encounters. However, the Irish bishops have not followed Rome's recommendations yet and should draw their inspiration from their French counterparts' successful diocesan programmes set up to strengthen Catholic identity through pastoral care and heritage enhancement activities. In a context of declining institutional authority and Church attendance, religious heritage and spiritual travels should not be overlooked and reduced to a tourism of memory. They should be seen as springboards for faith revival. 
PART III

Linking Products to Patrimoine 



\section{Irish Cultural Heritage through the Prism of Guinness's Ads in the 1980 os}

When one ponders the question of Irish patrimony, time and again, four words enter the mind of this author - music, sport, drinking and Guinness. Their status in Irish heritage is well established, going back hundreds of years and, in many instances, their paths are intertwined, often deliberately so by writers and musicians. This chapter contends that in the 1980 o Guinness blended many of its own decades-old symbols with more contemporary stimuli from music and sport, which were often influenced by international forces. Some might argue that this made Guinness seem less Irish but if that is true, does this make an Irish person who is open to international influences any less Irish? From its colourful backstory, to the ritual that surrounds the pouring of a pint, Guinness is capable of arousing intense feelings of pride among Irish drinkers and non-drinkers alike. For many decades, it has employed advertising in order to strengthen these bonds, bringing the brand's visual signifiers to the fore and associating them with the essence of what it means to be Irish: in particular music, sport and socializing with a pint of its stout.

In the mid-nineteenth century, Ireland's love affair with alcohol began in earnest when drinking became commonplace across all strands of society. Such was its ubiquity that it became one of the defining features of the nation's identity, a constant presence at all stages in an Irish person's life. Christy Moore's 1979 ode to the Irish patron saint, 'Patrick's Arrival', would lead one to believe that drinking was a national pastime as far back as the fourth century:

That day with a barrel of beer, he was drinking away with abandon.

Says Patrick, 'It's grand to be here'.

And they drank till they fell, yet by Jingo, the pot it still frothed o'er the brim. ${ }^{1}$ 
In his analysis of Irish drinking, Richard Stivers draws on a 1944 study by Robert F. Bales in order to explain why drinking became an integral part of Irish identity. As in other countries, the rise in popularity of alcohol was associated with celebration and rites of passage such as baptisms, marriages, wakes and emigration. However, Stivers foregrounds the unique forces present in Ireland that made alcohol's relationship with the Irish different to the one that existed with its nearest neighbours in England and Scotland. For example, in Ireland's largely agricultural economy, it was used as a social lubricant at marts in order to secure business transactions. A more worrying reason for drinking's widespread popularity was the Catholic Church's encouragement of fasting, which incited many of its congregation to substitute food with drink. ${ }^{2}$

Perhaps the single most important societal factor that contributed to Ireland's drinking culture was the low marriage rate that prevailed between I870 and 1940, an occurrence that can be attributed to the single inheritance farm economy. This gave rise to a disproportionately high number of bachelors. Unlike their married counterparts, they had few responsibilities but had a need for company and comradeship. Consequently, they spent much of their free time in the pub where their masculinity was judged on their ability to hold their drink. Here they were part of a community, a group of individuals who lived in similar circumstances. Married men joined them in the pub too, perhaps in the hope of re-capturing their freedom and of 'proving' themselves in this most male of environments. Henceforth, the pub became a focal point in Irish society for socializing, doing business and grocery shopping. ${ }^{3}$

Guinness was founded in 1759, which meant that it was already well established by the time the drinking habits of the Irish took off. Its 'heraldic heritage' was first used on its earliest bottle label in 1862 and with uncanny foresight the harp was registered as its trademark in 1876 . It has the same visual identity as Ireland's official national emblem, thus aligning itself firmly to the nation's DNA. The only difference is that Guinness's harp York: The Continuum International Publishing Group Inc, 2000, new revised edition). 
always appears with its straight edge to the left, whereas the straight edge of Ireland's harp is located on the right. ${ }^{4}$

The brewery's attention to the logistical side of the business in its formative decades meant that its barrels of porter became commonplace on the country's canals, which conveyed its unique product beyond the pale. When rail became the preferred mode of transport for moving merchandise, Guinness even built its own onsite railway, which linked the brewery to the national rail network. ${ }^{5}$ Never a company to stand still, it went on to acquire its own fleet of ships in the twentieth century and boats like the Miranda Guinness became a landmark on Dublin's city centre quays, thus establishing Guinness in the hearts and minds of inhabitants and visitors to the capital city. ${ }^{6}$

Guinness's reputation as a benevolent and pioneering employer differentiated it from most other employers and according to Rory Guinness, by the end of the nineteenth century, it was estimated that one in every thirty people in Dublin depended on the brewery financially. By then, employees were very highly paid, and unusually for that time, they received benefits such as pensions and medical care. Housing was built and provided by the Iveagh Trust. One of the more famous perks was that all male employees over the age of twenty-one were given an allowance of two pints each day and those men with physically demanding jobs were given an extra pint. ${ }^{7}$ This helped endorse the claims made in its advertising, such as 'Guinness for strength' or 'Guinness is good for you'. Consequently, Guinness's standing in Dublin went way beyond the commercial sphere. Its philanthropic philosophy infiltrated the lives of Dubliners and ensured its place in their hearts, regardless of whether or not they drank its porter.

However, its notoriety did not stop at the county's borders. In Roy Bulson's book on Irish pubs, Maurice Gorham captures Guinness's standing in the pub:

4 Guinness, Guinness: An Official Celebration of 2so Remarkable Years (London: Hamlyn, 2009), 30.

5 Rory Guinness, The World of Guinness (London: Scala, 2009), 26.

6 Guinness, Guinness: An Official Celebration of 25o Remarkable Years, 25.

7 Guinness, Guinness: An Official Celebration of 250 Remarkable Years, i5. 
In the traditional pub the standard drink is the pint of stout - Guinness's stout is in most parts of the country, though there are regions where other stouts prevail, and even where the traditional drink is ale. Most often you can look down a bar-counter at a busy time and see a perspective of tall black pints, topped with the creamy head, one before every customer, whilst a reserve regiment in every stage of filling stands ranked around the beer-taps or on the hobs between. Some people drink bottles of stout, some whiskey, some more exotic drinks, but in the traditional pub the overwhelming majority go for the pint. ${ }^{8}$

Decades later, Guinness's presence in the consciousness of Irish people still holds true, as discovered by Brenda Murphy in a number of interviews with Guinness drinkers and non-drinkers:

Guinness enters the texture of the daily lives of many Irish people. Even if they do not drink it, they are nonetheless aware of it, they have knowledge of it, and they know the myths and rituals and rules that surround the drink.

For several decades now, it is as if prominent writers, musicians and artists conspired to secure Guinness's place in Ireland's cultural heritage. Indeed some, like Brendan Behan, gained notoriety for consuming copious amounts of the beverage, all the time reinforcing the links between Guinness, creativity and identity. Despite his predilection for wine, in Ulysses James Joyce refers to Guinness as a signifier of what it means to be Irish when he cites the Guinness brewery alongside a long list of ancient treasures and landmarks. ${ }^{10}$ Carl O'Brien's report on the 2009 Bloomsday celebrations also highlights the link between Guinness and Joyce's classic novel, which, like the beverage, is part of Ireland's cultural heritage. The Irish proudly adopt it as one of the nation's treasures, regardless of whether or not they have read it. One of O'Brien's interviewees emphasizes Guinness's role in Ulysses, which is part of a ritual, steadfastly mimicked in the annual celebrations by domestic and international tourists. In other words, Bloomsday without Guinness would be incomplete:

8 Quoted in Roy Bulson, Irish Pubs of Character (Dublin: Bruce Spicer Limited, 1969), 9.

9 Quoted in Brenda Murphy, 'Guinness Consumption and Irish Identity', New Hibernia Review, Volume 7, Number 4, Winter 2003, 54.

IO Guinness, The World of Guinness, 50 . 
'And the Guinness', said Ena Smyth. 'The Guinness for breakfast, that's in it too. It's the only time of year you're allowed to have Guinness at eight o'clock in the morning. ${ }^{\text {,1 }}$

Meanwhile, Alan O'Riordan reminds readers that such is its reputation and infamy that writers do not even need to mention Guinness's name in their writings.

As Brendan Behan wrote in his Irish Sketchbook, 'Guinness is universally drank in Ireland'. Thus, the Irish poets can be familiar. 'Pint' means a pint of Guinness; 'stout' and 'porter' (a distinction little appreciated nowadays) similarly take the same brand in the mind of the reader. ${ }^{12}$

This is borne out in Flann O'Brien's classic poem, 'The Workman's Friend' in which he coined the phrase, 'A pint of plain is your only man'. Similarly, Christy Moore could only mean Guinness in his 1983 track, 'Lisdoonvarna' when he concludes: 'I don't need to worry about the weather. Ramble in for a pint of stout, you'd never know who'd be hangin' about. ${ }^{13}$ In a much more overt reference to Guinness in the 1985 ballad, 'Delerium Tremens', he muses, while all the time strengthening the link between Guinness and Irish popular culture:

As I sat lookin' up, the Guinness ad I could never figure out,

How your man stayed up on the surfboard after I 4 pints of stout. ${ }^{14}$

Of course, music has always formed an integral part of Irish patrimony, which explains why Guinness is so keen to associate itself with music, be it in ads or through high profile sponsorships, such as the Guinness Cork Jazz Festival. However, due to the burgeoning levels of outside influences

II Quoted in Carl O'Brien, 'Joyce and Bloomsday capture "soul of a people"' (The Irish Times, I7 June 2009). Available at: <https://www.irishtimes.com/news/joyceand-bloomsday-capture-soul-of-a-people-1.785488? mode $=$ print $\&$ ot $=$ example. AjaxPageLayout.ot>.

I2 Quoted in Alan O'Riordan, 'Fresh draughts of literary history' (The Irish Times, 28 September 2009). Available at: <https://www.irishtimes.com/culture/freshdraughts-of-literary-history-I.746464?mode=print\&ot $=$ example.AjaxPageLayout.ot $>$.

I3 Quoted in Frank Connolly, The Christy Moore Songbook, IIo.

I4 Quoted on Christy Moore's website. Available at: <https://www.christymoore. com/lyrics/delirium-tremens/>. 
on Irish culture, by the 1980 s, it was difficult to define what was meant by the term Irish music. Its exponents pursued a myriad of directions and counted country, rock, pop, folk and blues among the genres that inspired them. Consequently, O'Connor views the 1980 os as a time in Irish popular music history when rock and traditional music merged as Irish artists adopted a more contemporary style while maintaining an Irish voice. ${ }^{15}$

Did this imply that Ireland's music culture had all but disappeared by the eighties, having surrendered its identity to more powerful musical influences from around the world? Vignoles argues that: 'It's almost impossible for a country like Ireland to have an independent pop music culture, given Britain's size, its media's influence and its linguistic dominance. ${ }^{16}$ However, Irish music as a category continued to exist, as Irish artists who were successful on the international stage were just as likely to be categorized according to their nationality as their music genre. On paper at least, this kept the Irish music category alive, but even this is something that puzzles Bono. $\mathrm{He}$ muses about the benign cultural backdrop against which he grew up. $\mathrm{He}$ contends that, at a surface level at least, there is nothing particularly Irish about his music and that it was influenced by the same things that might have influenced his contemporaries in Britain. However, he admits that $\mathrm{U}_{2}$ 's music does betray the nationality of the band because if one listens to the lyrics, honesty and passion permeate them in a way that he feels is lacking in the words of British musicians. He recalls how he was 'called a "White Nigger" once by a black musician, and I took it as he meant it, as a compliment. The Irish, like the blacks, feel like outsiders. There's a feeling of being homeless, migrant, but I suppose that's what all art is - a search for identity. ${ }^{17}$ These words were spoken in 1988 , when emigration

I5 Nuala O'Connor, Bringing It All Back Home: The Influence of Irish Music (London: BBC Books, 1991).

I6 Julian Vignoles, 'What Is Irish Popular Music?' The Crane Bag, Volume 8, Number 2 (Richard Kearney, 1984), 72. Available at: <http://www.jstor.org/stable/30023280>. [Accessed 14 February 2017].

I7 Paul Hewson, Paul Durcan, Neil Jordan and Robert Ballagh, 'Migrant Minds' in Richard Kearney (ed.), Across the Frontiers: Ireland in the rggos (Dublin: Wolfhound Press, 1988), 190. 
rates were still very high. Significantly, they articulate the struggles that often went through the minds of both those who left, as well as those who stayed behind in Ireland in the 1980 s.

In 1982, Guinness launched a series of TV and print ads that included musicians who had achieved success in both Ireland and abroad. Like Guinness, many of them were 'national treasures', firmly embedded in the cultural landscape and capable of complementing the beverage's traits in ways that Irish audiences would understand. The Chieftains featured in the first of the TV ads, in what was referred to as the No beer comes near series. They achieved what O'Connor describes as 'supergroup' status in the I970s and this was underlined in 1982 when they performed at Slane Castle with American artists The J. Geils Band and George Thorogood and the Destroyers. ${ }^{18}$ The headline act was The Rolling Stones. Slane Castle hosted its first stadium style concert in $198 \mathrm{I}$ with great aplomb, although that year was a much more Irish affair, headlined by Thin Lizzy. However, like The Chieftains, they too were internationally acclaimed and capable of drawing a large crowd. It would appear that this is an important determinant of success in Ireland for Irish artists. Vignoles contends that unless Irish bands make it in England or America, they are unlikely to enjoy high levels of success in their home market, regardless of talent. In 198I, $U_{2}$ were a mere support act at Slane because they had not yet made it on the international stage. Vignoles notes that in 1982 , they attracted a crowd of around 3,000 to Punchestown but it was not until the following year, when they had achieved success abroad, that around $\mathrm{I} 8,000$ music lovers went to see them at the same venue. ${ }^{19}$

It was important for Guinness to align the brand with artists that would appeal to its target audience, in the same way that the artists themselves would appeal to the record-buying and concert-going public. The Chieftains and the other musicians in the series fell into this category. The international popularity of The Chieftains is clear in the ad. It is largely set in New York, a popular destination for Irish emigrants since emigration began and it features live performances in front of very large audiences. The voiceover in the ad links Guinness with the band: 'The cream of the head. The unmistakeable taste. 
The unmistakeable sound'. The success of both Guinness and The Chieftains is comparable. The word 'cream' is a metaphor for 'best' and 'Guinness' and at that time both were deemed the best in their category.

The point is that Guinness is equally at home in Ireland as it is in New York, but by being there, it brings a little bit of Irish culture to a place where Irish people feel at home. Like the Irish, Guinness travels without losing its strong Irish identity. Throughout the ad, there is a sense that being able to enjoy Guinness during their downtime, makes them feel at home. This puts them on a similar footing with fellow Irish travellers, be they emigrants, holidaymakers, or business travellers.

Clannad was another one of Ireland's most successful groups in the I970s and 1980 s. Their Irish provenance was never in doubt, despite the fact that their music was a mix of Irish and international genres, including folk, jazz and classical. Technology was widely used in popular music at that time, with bands like Depeche Mode and Kraftwerk enjoying considerable success across Europe. Clannad embraced technology in their music, adding an otherworldliness to their sound. In doing so, they demonstrated a willingness to put a contemporary twist on their deeply rooted Irish sound. They utilized all that was positive about Irish identity, in that they drew on a deep well of Irish music influences, marrying them with contemporary techniques and genres to create their own unique sound. In 1982 , they became the highest charting Irish artists in the British charts by reaching number five with the theme song from the Yorkshire Television production, Harry's Game. In 1983, following on from this success, Guinness invited Clannad to feature in an ad in the No beer comes near series. Like The Chieftains, they achieved considerable success outside of Ireland and therein lay their appeal to a wider audience. This status is conveyed in the advert, which is mostly set in the environs of the world famous Concert Hall, Gebouw in Amsterdam.

Later in the advert, the band is transported back to the top of a cliff in Ireland, most likely in their home county of Donegal. Surrounded by megalithic stones, symbols of Irish heritage, Pól and Ciarán sit at a picnic table. A pint of Guinness stands among sheets of music, reinforcing the link between Guinness, music and creativity. The atmosphere is magical, remote and ethereal. Although it is night-time strong, unearthly shades of intense blue and green prevail. This particular scene appears to be influenced 
by David Mallet, who directed David Bowie's seminal music video for the global 1980 hit, Ashes to Ashes. That particular video is surreal and uses technology to create vivid, surreal colours. The openness of Irish culture to international forces is laid bare in that scene, but rather than killing it, it helps it evolve and remain relevant in a more contemporary Ireland.

Another ad in the same series features the English singer, Elkie Brooks. She enjoyed stellar success in the UK and Ireland in the I970s, with hits like 'Lilac Wine' and 'Pearl's a Singer'. Her star still shone brightly in the early years of the 1980 s and in 1983 she fronted an ad for Guinness. Partnering The Chieftains was a more obvious choice for Guinness, not just because they are Irish but because, when the ad was made, the band members were men in their late thirties, representative of the typical Guinness drinker. Elkie Brooks was around the same age, but as a woman she symbolized a much smaller group of Guinness drinkers, namely females. She embodied independence and determination and she had made it in an industry dominated by men. Despite her success, she came across as a very natural, down-to-earth person, someone to whom women and men could relate. By selecting an English woman and filming her in an Irish environment, Guinness capitalized on the fluid state of communications that had widened its target audience's horizons. Many Irish people at that time would have been just as familiar, if not more so, with music and entertainment that originated outside the State. This situation was copper-fastened when the global music channel, MTV, was launched in 1983 (the same year the ad was made). Its remit was to deliver popular music from all over the world into the homes of young, Irish people, twenty-four hours a day, seven days a week. The democratization of communications willingly tapped into a cohort that typically embraced change and, with that, music went global.

Meanwhile, a number of very famous sports stars featured in a series of Guinness print ads. All of them were Irish or declared for Ireland due to their ancestry and they participated at the very highest levels of their sports. $1982 / 3$ were standout years for most of the featured sportsmen, so when Guinness ran the ads in 1983 , they were of great interest to the public. Irish international football stars Kevin Moran and Frank Stapleton proudly endorsed Guinness. As well as representing Ireland on the pitch, they achieved FA Cup glory with Manchester United in 1983 , so their stars were very much 
in the ascendancy. By 1983, Irish-American tennis player Matt Doyle was at the peak of his powers and was part of the first Irish team ever to compete in the World Group stages of the Davis Cup. The tie raised the profile of California-born Doyle, who soon became the number one ranked tennis player in Ireland. This made him an ideal ambassador for Guinness because an Irish audience could relate to his heritage (see Figure 7.I). He was born in the United States, he spoke with an American accent but he had Irish roots and his name was very familiar. Many Irish people had American cousins with a heritage just like his, so it did not seem strange that he would want to represent Ireland in competitive sport.

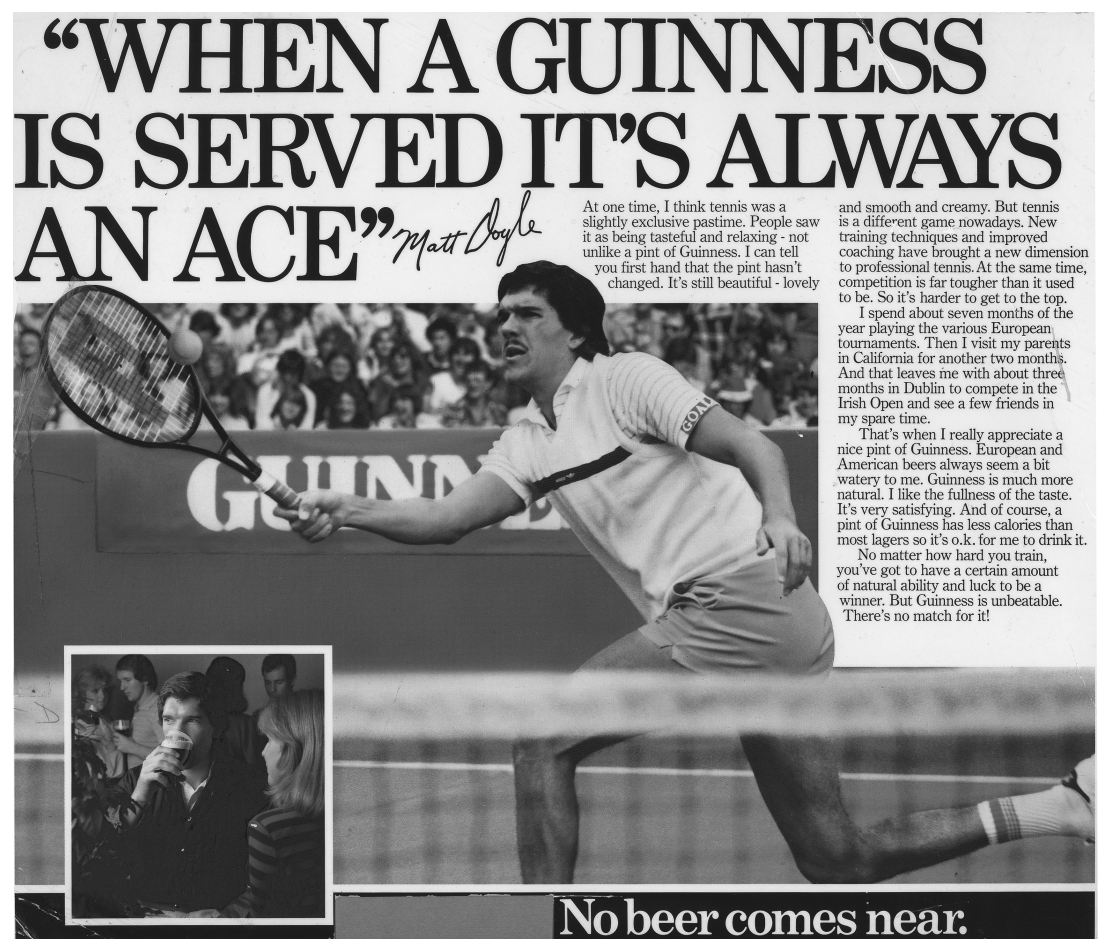

Figure 7.I. No beer comes near (Matt Doyle $)^{20}$

20 All copy from print and TV ads cited in this paper is reproduced with permission of the Guinness Archive, Diageo Ireland. Guinness adverts have changed over the years 
Similarly, Ray Houghton, a Scot with Irish ancestry, featured in a print ad for Guinness in 1989 (see Figure 7.2). That year, he scored the winning goal for Ireland against England in the European Championships and with that achieved notoriety in Ireland.

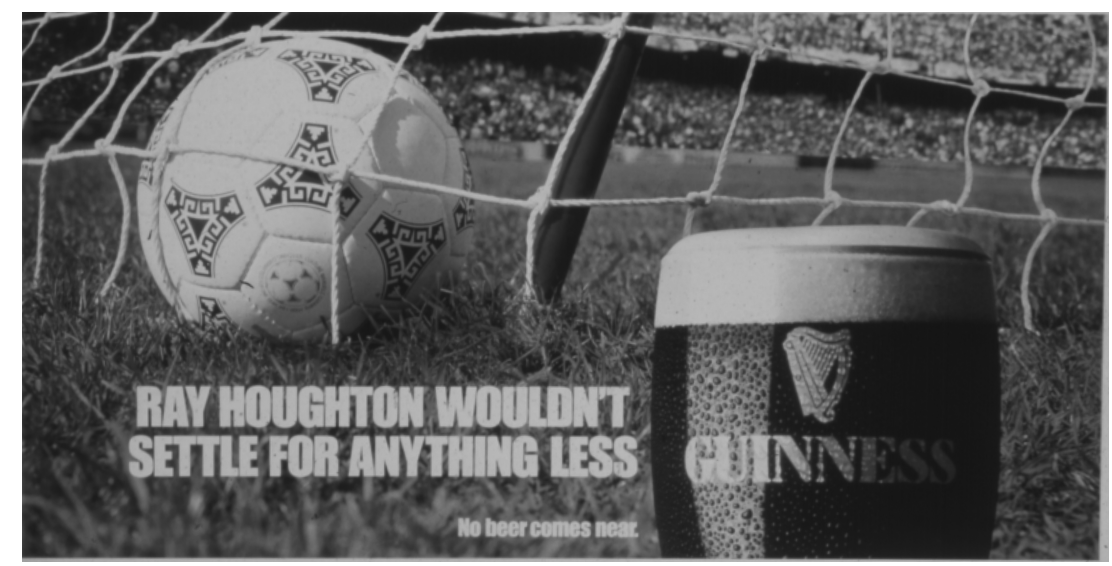

Figure 7.2. No beer comes near (Ray Houghton)

The sportsmen had much in common with many Irish people. They journeyed to other countries to find success and, even those who were the offspring of previous generations of Irish emigrants, donned the green jersey with pride. Leaving Ireland had not made these people feel or seem any less Irish and most onlookers could relate to their journeys. 1980s Ireland was an economically battered country, precipitating the exodus of thousands of young men and women. Between I98I and 1990, 358,000 people emigrated from Ireland. ${ }^{21}$ The UK attracted the lion's share of the emigrants,

and they are continually evolving to take into account the changing society, advertising rules as well as the internal standards that make Diageo a responsible business. These adverts may contain historical product claims that are not now endorsed by Diageo. In making those adverts available, the intention is not to promote benefits of drinking but to show Guinness advertising over more than sixty years.

2I NESC, The Economic and Social Implications of Emigration. Number 90 (Dublin: National Economic \& Social Council, I991). 
with around 68 per cent opting for the close proximity of Ireland's nearest neighbour. A not insignificant I4 per cent went to the United States, where immigration policies were selective but not off-putting. Emigrants were most likely attracted by the presence of previous generations of emigrants and a familiarity with its culture, borne from the ubiquitous American dramas seen on Irish television and cinema screens. Neil Jordan captures the impact of this when he recalls how on a trip to the US, he realized that the cultural and physical landscape he encountered there was more familiar to him than what he had experienced at home. He put this down to the all-pervasive American culture evident in the media at that time. ${ }^{22}$

In the midst of all the hardship imposed by the dire economic scenario, life continued for those who remained in Ireland. Where there is disposable income, there is advertising, and its stories provide an insight into the state of a nation at a particular point in time. Advertising is an optimistic pursuit and usually seeks out the positives in any scenario. In his critique of Irish advertising, Moran contends that most ads are aimed at people with money, therefore perpetuating an idealized view of society. $\mathrm{He}$ identifies a clear shift in the focus of alcohol advertising in the 1980 s, from promoting the tangible pleasures of the drink, to eulogizing the pleasures that are visited upon those who drink it. ${ }^{23}$ The $1980 / \mathrm{I}$ advert Racehorse from Guinness is a case in point. It pays homage to many of the lifestyle changes that were visited on Irish people since the 1970s, with no reference to any negatives. The soundtrack is contemporary and would have resonated equally well with an international audience. At that time, Irish viewers were undoubtedly watching the $\mathrm{BBC}$ 's Top of the Pops chart music programme, or Vincent Hanley's MT USA, which broadcast all the latest music videos from around the world on RTÉ, just as they were listening to home-grown musicians. Rather than focusing on just one theme, Guinness presents a collage of scenarios that fosters 'an association in the viewer's

22 Paul Hewson, Paul Durcan, Neil Jordan and Robert Ballagh in Across the Frontiers: Ireland in the Iggos.

23 Ciarán Moran, 'The Advertising Agency View of Ireland: Conservative MonoCulture'. The Crane Bag. Volume 8, Number 2 (Richard Kearney, 1984), 84-9. Available at: <http://www.jstor.org/stable/30023283>. [Accessed I4 February 2017]. 
mind between the desirable activities which befall elegant people and the consumption of the advertised beverage', in this case, Guinness. ${ }^{24}$ There are fleeting references to the product itself, but the main message goes beyond its attributes. The advert makes sense of the cultural shift in Ireland because the storyline is set in an overtly consumer society. The style corroborates a view articulated by Rowley, who observes that the idea of personal happiness through love has been linked to consumerism, in the iconography of the happy couple who have responsibilities only to each other and their careers. ${ }^{25}$ This suggests a shift in the way in which Irish people's lives and aspirations were represented, with the advertising industry taking the lead. The advert might be viewed as a short montage that encapsulates this change and tells of more contemporary, aspirational lifestyles.

Such rhetoric contrasts sharply with Declan Kiberd's critique of Irish literature and its take on Irish society. He surmises that despite their socialist leanings, most literary pieces are wedded to the idea of Irish tradition. Consequently, he is quite scathing when he challenges that narrative:

So one is forced to ask if all this talk of tradition has a basis in contemporary Irish reality. Do the families of suburban Dublin wake up sweating under the burden of Irish tradition? Do their children feel ravaged by crises of national identity as they reach for the multinational snap-crackle-and-pop? And the answer is clearly no. This obsession with tradition is a product of the conservative academic mind, endlessly rehearsing themes for an Irish-American audience. In their hearts, our scholars suspect that all this talk of tradition has a great deal more to do with tourism than with art, with peddling a national image than with understanding ourselves. ${ }^{26}$

The Racehorse advert is aimed at precisely this new generation of Irish consumers, alluded to by Kiberd when he suggests that contemporary Ireland is

24 Ciarán Moran, 'The Advertising Agency View of Ireland: Conservative MonoCulture', 85.

25 Quoted in Rosemarie Rowley, 'Thinking Globally and Acting Locally' in Richard Kearney (ed.), Across Frontiers: Ireland in the rggos (Dublin: Wolfhound Press, I988), 91.

26 Quoted in Declan Kiberd, 'Inventing Irelands'. The Crane Bag, Volume 8, Number I (Richard Kearney, 1984), I2. Available at: <http://www.jstor.org/stable/30059548>. [Accessed 14 February 2017]. 
much more outward looking than some observers might like to admit. Such shifts in identity and societal orientation occupied the minds of many commentators in the 1980 s. This was a time when the EEC was moving closer towards greater cohesion, as a result of the forthcoming Single European Act, which would be ratified in 1992. Consequently, Brussels would have much greater power and influence over Ireland, but from a positive perspective, it had the potential to facilitate improvements in the fabric of Ireland's economic and social infrastructure. All of this change contributed to uncertainty in people's minds and, in much the same vein as Kiberd, Richard Kearney asserts that 1980 s Ireland faced an identity crisis:

A national ideology begins to degenerate into rhetoric when it ceases to address the reality of people's experience .... A yawning gap has emerged between the official expressions of the nation-state and the everyday experience of its citizens. ${ }^{27}$

However, despite a growing disconnect between many Irish citizens and traditional cultural heritage in the 1980 os, Kearney cautions against 'jettisoning' it. Rather, he views it as an opportunity to reinvent it in such a way that it meets the challenges of contemporary Ireland. The signifiers in the advert Racehorse suggest that Guinness was well aware of this crisis and accepted that traditional representations of identity no longer resonated with Irish people to the same extent. The advert imparts an idealized view of Irish identity but captures the growing influence of international cultural references on everyday life. It is not suggested here that images of Concorde and chichi breakfast rendez-vous represented reality for the vast majority of people in the 1980 . Concorde was unattainable for most people, but it signified the democratization and perceived glamour of international travel. By the beginning of the 1980 s, Budget Travel was a staple among many Irish holidaymakers and a return to emigration had started to take hold. Consequently, Guinness recognized that Irish people were just as comfortable imagining themselves in situations beyond Ireland's shores as they were with their country of origin.

27 Quoted in Richard Kearney, Transitions: Narratives in Modern Irish Culture (Dublin: Wolfhound Press, I988), iIs. 
At the start of the 1980 s, Ireland was still a very homogeneous society but horizons had broadened. Towards the end of the decade, this outward orientation was debated by Kearney when he cautioned that Ireland could 'no longer be contained within the frontiers of an island. ${ }^{28}$ Due to technological advances, the tide of emigration that visited Irish shores in the 1980 os differed from previous episodes of migration in that emigrants did not necessarily face permanent exile. Even if they were unable to return in person, it was easier for them to keep in touch with home as a result of a changing communications landscape. These changes were well documented in the late seventies when Sean MacBride presided over an extensive piece of research that was compiled by the International Commission for the Study of Communication Problems. It examined the implications of the burgeoning changes that were emerging in worldwide communications at that time. From the outset, it established that communication plays an integral role in spreading culture in individual countries, thus helping to preserve their heritage. It did not advocate that countries should retreat within their own boundaries in order to safeguard their cultural specificity. Rather, it acknowledged the importance of communication's role in: 'widening the individual's horizons, awakening his imagination and stimulating his aesthetic needs and creativity.'29

The authors caution that while the inter-dependence of culture and communication between countries may offer smaller countries the opportunity to bring their cultures to a wider audience, it is very possible that they may be overpowered by outside influences. The report reminds the media of its responsibilities, 'because they do not merely transmit and disseminate culture but also select or originate its content. ${ }^{30}$ The implications of the findings were prescient, as they suggested that Ireland was

28 Quoted in Richard Kearney (ed.), Across the Frontiers: Ireland in the rggos (Dublin: Wolfhound Press, I988), 7.

29 Quoted in International Commission for the Study of Communication Problems, Many Voices, One World: Towards a new more just and more efficient world information and communication order (London: Kogan Page; New York: Unipub; Paris: UNESCO, 1980), i4.

30 Quoted in International Commission for the Study of Communication Problems, Many Voices, One World, 30. 
more open to outside influences than in previous decades. The prospect of what the authors term 'cultural domination' is very real and the perils are clearly articulated with a sense of foreboding when it opines that 'cultural identity is endangered by the overpowering influence on and assimilation of some national cultures through these nations may well be the heirs to more ancient and richer cultures. Since diversity is among the most precious qualities of culture, the whole world is the poorer. ${ }^{31}$

Such a vista was one that Ireland's inward-looking, post-Independence Governments railed against up until the late 1950s. The paucity of communications technology aided their vision. However, an inward-oriented outlook was impossible to sustain with the arrival of television and the remarkable growth in travel to and from the island. By the 1980 s, Ireland's TV screens were dominated by the BBC, a far richer and better resourced corporation than RTÉ could ever be. In addition, domination by British media was further strengthened by the availability of UTV and new arrival, Channel 4. The ramifications of a British-led TV media landscape are reinforced by Bell, who concedes that due to the rising volume of trans-border data-flows controlled by transnational corporations, individual countries are less able to regulate the flow of information and entertainment. $\mathrm{He}$ argues, 'in so far as the integrity of nation states rests on a degree of cultural hegemony within their political boundaries, national sovereignty is potentially eroded. ${ }^{32}$

In the 1980 s, Irish authorities participated in European cable and satellite broadcasting projects. However, their mandate remained the pursuit of broadcast strategies aimed at preserving Ireland's culture and identity. According to Bell, ${ }^{33}$ senior management in RTÉ was optimistic, surmising that digital satellite technology would enable the national broadcaster to extend its coverage across the UK and some European countries, including

3I Quoted in International Commission for the Study of Communication Problems, Many Voices, One World, 3 I.

32 Quoted in Desmond Bell, 'Proclaiming the Republic: Broadcasting Policy and the Corporate State in Ireland', West European Politics. Vol. 8, Issue 2 (Broadcasting and Politics in Western Europe, 1985), 27.

Desmond Bell, 'Proclaiming the Republic', 27-49. 
Spain and Portugal. This conforms to Kearney's assessment of the situation, as he refuses to view the communications revolution as a threat, but an opportunity to import cultures. As a quid pro quo, it would be easier for the Irish to export their culture to other parts of the world. He observes that:

Post-modern culture crosses national boundaries. It is culture without frontiers. But in order to resist the domination of a centralised bureaucracy of communication, the post-modern task is to ensure that a culture without frontiers does not degenerate into a culture without differences. ${ }^{34}$

Herein lay the challenge, namely, how to nurture, promote and sustain all that was good about Irish culture, without remaining wedded to the past and closed to new ideas. The International Commission for the Study of Communication Problems refers to the homogenization of different societies, ably assisted by the surge in levels of information and entertainment transfer: 'Life-styles, habits and manners, tastes and preferences, even beliefs and opinions tend to become uniform, to the detriment of social variety and human individuality. ${ }^{35}$ This is just as likely to occur within countries as between countries, when urban ideals 'infiltrate' rural customs and traditions. However, Ireland's close proximity to the UK offers an example of inter-country cultural dominance, which due to the nature of the communications infrastructure, is logically driven by the UK. This may precipitate a lack of clarity about a nation's identity. According to Fennell, nations should have a clear idea of where their own identity ends and others begin. ${ }^{36}$ The disintegration of boundaries between nations makes this task tougher. Irish identity in the 1980 s is an example of such a scenario, with emigration and a more deregulated communications landscape making

34 Quoted in Richard Kearney, 'Postmodern Ireland' in Mark Patrick Hederman (ed.), The Clash of Ideas: Essays in Honour of Patrick Lynch (Dublin: Gill and Macmillan, I988), 127.

35 Quoted in The International Commission for the Study of Communication Problems, I60.

36 Desmond Fennell, 'Creating a New Irish Identity', in Studies: An Irish Quarterly Review, Vol. 75, No. 300 (Winter). Available at: <http://www.jstor.org/stable/30090792>. [Accessed 22 November 2015]. 
their presence felt. Without realizing it, many Irish people assimilated cultural reference points from other nations. Judging by many of its ads in the $198 \mathrm{os}$, Guinness understood the significance of the internationalization of popular culture in Ireland.

For many Irish people, the 1980 os was memorable as a result of the hardship that was visited upon them. This dark period in Ireland's recent past coincided with the acceleration of internationalization, which challenged its culture and identity. Rather than dwelling on the negatives of such forces, Guinness's advertising mainly sought to instil its messages with an air of optimism and positivity. More than that, it revisited some of the essential components of Ireland's patrimony. It set about doing this with a contemporary twist, by tapping into popular cultural reference points in a way that was complementary to the Guinness brand identity. In so doing, Guinness reminded audiences of its own rich heritage by interspersing centuries-old tropes, such as the harp, alongside some of the symbols and stories that represented a nation in transition.

Like Irish people during the 1980 s, Guinness looked beyond the confines of Ireland for inspiration by employing an outward-looking approach, thus enabling the brand to connect with Irish consumers. It did not ignore the emotive issue of emigration but refused to focus on the downsides. Most notably, its ads showcased the successes enjoyed by Irish people who worked in other countries. Granted, they featured high profile artists like the Chieftains and Clannad, as well as successful sportspeople like Kevin Moran and Frank Stapleton. Their bonds with Ireland were evident in the deliberately crafted copy in the ads, which highlighted the ease with which they travelled across boundaries to ply their trades. Those left at home while their sons and daughters, brothers and sisters, aunts and uncles built new lives in the UK and the US, might have been reassured to know that despite their loved ones' commitments abroad, Ireland would always be home. First and second-generation emigrés like Matt Doyle and Ray Houghton provided comfort too. They symbolized the possibility that even the children and grandchildren of emigrants were deeply connected to their Irish roots.

Many of Guinness's ads in the 1980 s captured the extent of Ireland's internationalization and its impact on Irish culture. The inclusion of 
international music artists like Elkie Brooks sat comfortably with an audience well-versed in non-indigenous music. As if sensitive to the enormity of the changes facing Irish audiences, tropes that symbolized Ireland's ancient roots were interspersed with contemporary, imported images. Hauntingly beautiful glimpses of dolmens reassured viewers that the inexorable journey towards internationalization did not have to mean a total desertion of the past. The level of self-examination that occurred in the wake of these changes was led by the likes of Kiberd, Kearney and Bono when they declared that Irish people in the 1980 s, particularly urban dwellers, were much less influenced by Irish traditions than they were by the international products and cultural reference points that infiltrated their lives on a daily basis. This was inevitable in a world where communications boundaries were being toppled, leaving most countries open to outside influences. Why would Ireland be any different? A new chapter in Ireland's heritage was being written and Guinness was a keen student of what it had to say. 



\section{A Traditional Irish Family Butcher Shop: 'Harnessing the power of Patrimoine'}

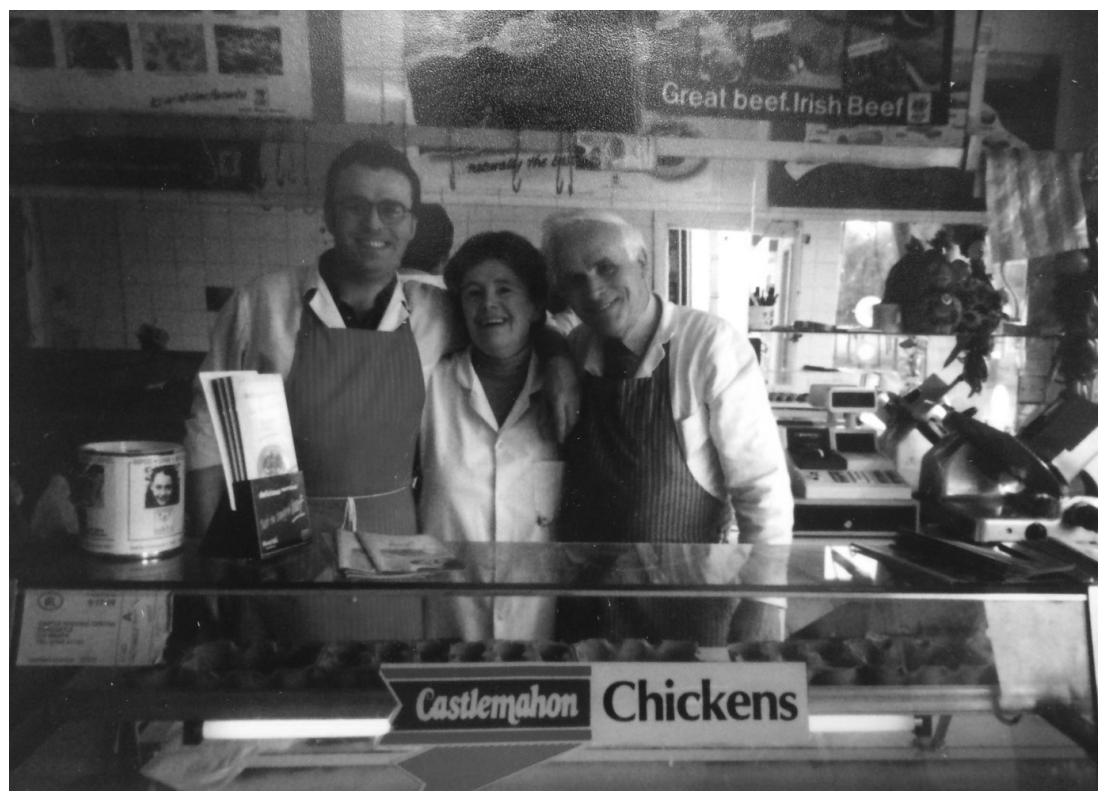

Figure 8.I. Brian Murphy, Lucy Murphy and Michael Murphy on the final day of M. J. Murphy's Butcher Shop ${ }^{1}$

This chapter examines an often overlooked aspect of Ireland's gastronomic heritage, namely the traditional family butcher shop. For many years, both in urban and rural settings, in a similar way to the pub, the post office and

I This photo (Figure 8.I) was taken one day before M. J. Murphy’s Butchers was handed over to new owners. 
the Garda station, the small family butcher shop has been disappearing from our village centres and our urban main streets. It has been subsumed into meat counters in large international retailers where the traditional aspects of the Irish butcher shop have all but disappeared to be replaced by an often faux-authentic approach to butchery; that is to say, where the impression of the traditional shop is created but there is very little in terms of traditional Irish butchering heritage evident. This chapter explores how the authentic Irish family butcher shop in Ireland can exploit its cultural heritage as a traditional gastronomic entity to capitalize on its associated sense of patrimoine. It explores where this sense of patrimoine comes from and how these origins can be utilized to best effect. Throughout the chapter, I argue that in order for a traditional business to survive in contemporary Ireland's open and competitive market place, that business needs to exploit and promote its cultural heritage qualities.

The theoretical framework that is used for discussion and analysis throughout the course of this chapter is based on the 'Fourth Space Model' as defined by Murphy. ${ }^{2}$ This model provides an engagement template for how any modern food and beverage site might interact with its audience and successfully communicate a true sense of that illusive quality, terroir. In this instance, terroir is understood to mean a sense of unique heritage tied to both place and the story of that place. In our increasingly homogenized world, the association between high quality epicurean fare with a sense of place-integrity is ubiquitous. The traditionally defined French concept of terroir was originally an oenological term, but has in recent years attracted the attentions of writers such as Marion Demossier, who contend that it has become a touchstone for many disciplines, such as sociology and cultural theory. ${ }^{3}$ The concept itself has become an overused phrase in gastronomic terms. It has been

2 Brian Murphy, 'Communicating New Definitions of Terroir to a Millenial Audience through the Medium of Fourth Space', in Kulinarischer Tourismus und Weintourismus (Wiesbaden: Springer Gabler, 2017), 85-92.

3 Marion Demossier, 'Beyond terroir: territorial construction, hegemonic discourses, and French wine culture', Journal of The Royal Anthropological Institute [serial online], December 20II, I7 (4): 685. [Accessed 6 February 2018] 
taken from its wine-related French roots and co-opted successfully by a wider English speaking food community and it is the very essence of terroir that helps convey our patrimoine message. In a way, it has become a 'culinary brand' that attempts to encapsulate a myriad of food-related themes such as locally produced food, regional specificity, artisan production and authenticity. We have numerous examples of the term's adoption by the culinary world. We now have terroir-driven restaurants, terroir-focused chefs and terroir-based cuisines. In November 2016, Dublin hosted the inaugural 'Tourroirs: Food Tourism and Culture' conference in Croke Park. ${ }^{4}$ In order to position a food business using a Fourth Space model the business needs to identify ways of promoting its sense of cultural identity to an audience who increasingly demand such attributes.

Given the word's over-exposure, there is an argument to return to the roots of terroir's original meaning and to explore again the lessons that we can learn from the French with regard to expressions of place, regionality and heritage. Terroir means so much more than simply land or soil, even though the soil does constitute an important component part of it. Tomás Clancy, one of Ireland's foremost wine writers, confirms that the direct result of this French attitude to terroir is the appellation contrôlée (AOC) system. ${ }^{5}$ It has been in legal existence for over eighty years, and came about due to the need for the French government to formally protect the production of its local wines from cheaper and often fraudulent competitors. In essence, it and subsequent AOC laws have been an attempt to protect and anchor notions of terroir to specific places. Various scholars have in more recent years expanded on the definition and taken it into a more sociological realm. Marion Demoissier has examined inextricable links between terroir, culture and food.

5 Tomás Clancy, 'Around the world with Pinot Noir', in The Sunday Business Post, 8 March 2009 <http://archives.tcm.ie/businesspost/2009/03/08/story40007.asp>. [Accessed 21 April 2009]. 
the validity of terroir as a social construct. ${ }^{6}$ Others, such as Amy Trubek, insist that 'culture, in the form of a group's identity, traditions and heritage in relation to place, must also be part of the equation'. 'Such concepts are perhaps less tangible than our traditional understanding of terroir, but they are nonetheless valid and align the concept of terroir closer to a sense of patrimoine as understood in French culture. The difficulty arises when one attempts to communicate such place-integrity and heritage to increasingly gastronomically-aware audiences. This is where the Fourth Space model can be of particular use. As it provides a simple to understand framework for developing a strategy that will help any small food or drink business identify key aspects of their cultural heritage and subsequently convey these to an audience. The name of the model is born out of Ray Oldenburg's identification and exploration of Third Places. ${ }^{8}$ However the model used here takes the much more encompassing name of Fourth Space to include sites that not only display Oldenburg's Third Place qualities as a key attribute, but which also convey a much broader range of important qualities in the areas of gastronomic identity, place integrity, technology, cultural economy and legacy. ${ }^{9}$ It suggests that in order to convey such cultural qualities, as captured in the broadest definition of terroir, five strands of engagement need to be activated to varying degrees. These five are pictured in Figure 8.2.

6 Marion Demossier, 'Beyond terroir: territorial construction, hegemonic discourses, and French wine culture', 686.

7 Amy Trubek, The Taste of Place: A Cultural Journey into Terroir (London: University of California Press, 2009), 91.

8 Ray Oldenburg, The Great Good Place (Philadelphia, PA: Da Capo Press, 1998).

9 Third Place qualities are just one of the attributes analysed using The Fourth Space model which deals with a variety of equally important qualities that are necessary when enhancing a sense of patrimoine. 


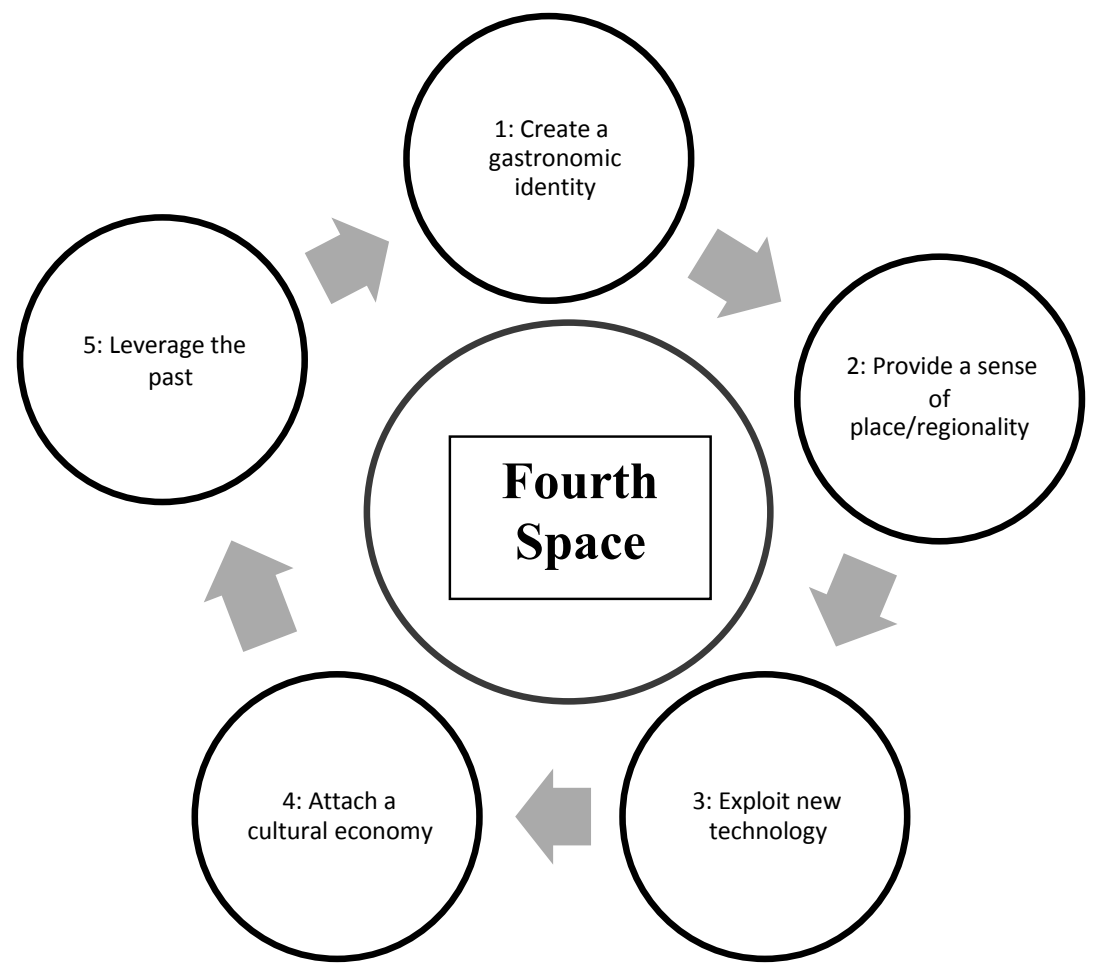

Figure 8.2. The Fourth Space Model

Each of the strands highlighted in the Fourth Space Model has a number of analysis subheadings, as described in the Figure 8.3 matrix.

\begin{tabular}{|l|l|l|l|l|}
\hline \multicolumn{1}{|c|}{ Strand I } & \multicolumn{1}{|c|}{ Strand 2 } & \multicolumn{1}{c|}{ Strand 3} & \multicolumn{1}{c|}{ Strand 4 } & \multicolumn{1}{c|}{ Strand 5} \\
\hline $\begin{array}{l}\text { Create a } \\
\text { gastronomic } \\
\text { identity }\end{array}$ & $\begin{array}{l}\text { Provide a } \\
\text { sense of place/ } \\
\text { regionality }\end{array}$ & $\begin{array}{l}\text { Exploit new } \\
\text { technology }\end{array}$ & $\begin{array}{l}\text { Attach } \\
\text { a cultural } \\
\text { economy to the } \\
\text { product }\end{array}$ & $\begin{array}{l}\text { Leverage the } \\
\text { past }\end{array}$ \\
\hline $\begin{array}{l}\text { Incorporate } \\
\text { a third place } \\
\text { function }\end{array}$ & $\begin{array}{l}\text { Emphasize } \\
\text { place of origin/ } \\
\text { regionality }\end{array}$ & $\begin{array}{l}\text { Use technology } \\
\text { to bridge the } \\
\text { place and story } \\
\text { gap }\end{array}$ & $\begin{array}{l}\text { Provide } \\
\text { authentic links } \\
\text { to a product's } \\
\text { culture }\end{array}$ & $\begin{array}{l}\text { Emphasize the } \\
\text { importance } \\
\text { of past related } \\
\text { place anchors }\end{array}$ \\
\hline
\end{tabular}




\begin{tabular}{|l|l|l|l|l|}
\hline \multicolumn{1}{|c|}{ Strand I } & \multicolumn{1}{|c|}{ Strand 2 } & \multicolumn{1}{c|}{ Strand 3} & \multicolumn{1}{c|}{ Strand 4 } & \multicolumn{1}{c|}{ Strand 5} \\
\hline $\begin{array}{l}\text { Convey the } \\
\text { story of place }\end{array}$ & $\begin{array}{l}\text { Avoid } \\
\text { fauxthenticity }\end{array}$ & $\begin{array}{l}\text { Facilitate } \\
\text { elements of } \\
\text { 'Tourism } \\
\text { without Travel' }\end{array}$ & $\begin{array}{l}\text { Conflate with } \\
\text { other cultural } \\
\text { activities }\end{array}$ & $\begin{array}{l}\text { Become rooted } \\
\text { in real stories }\end{array}$ \\
\hline $\begin{array}{l}\text { Act as a } \\
\text { cultural } \\
\text { ambassador to } \\
\text { tourists }\end{array}$ & $\begin{array}{l}\text { Provide an } \\
\text { educational } \\
\text { medium/ } \\
\text { enable } \\
\text { decodification }\end{array}$ & $\begin{array}{l}\text { Provide } \\
\text { personal } \\
\text { interactions } \\
\text { before and after } \\
\text { the touristic } \\
\text { experience }\end{array}$ & $\begin{array}{l}\text { Strive for } \\
\text { cultural capital } \\
\text { while avoiding } \\
\text { exploitation }\end{array}$ & $\begin{array}{l}\text { Consider } \\
\text { the role of } \\
\text { invented } \\
\text { traditions' }\end{array}$ \\
\hline $\begin{array}{l}\text { Provide } \\
\text { authentic } \\
\text { people } \\
\text { engagement }\end{array}$ & $\begin{array}{l}\text { Allow for a } \\
\text { food and place } \\
\text { link }\end{array}$ & $\begin{array}{l}\text { Target } \\
\text { millennial } \\
\text { audiences }\end{array}$ & $\begin{array}{l}\text { Exploit host } \\
\text { country links }\end{array}$ \\
\hline
\end{tabular}

Figure 8.3. Key strands of the Fourth Space Model

Using the much broader definition of terroir described earlier, we can see how the strands of Fourth Space as outlined in Figure 8.3 might underpin and enhance that sense of terroir in certain situations. The best way to analyse how a Fourth Space approach might work in practical terms is to overlay that Fourth Space model onto real business examples. To do this, we will use the example of two traditional family butcher shops. Both are very similar in origin but, as will be seen, are separated by time, location, scale and success.

The first businesses I have chosen is the small M. J. Murphy's family butcher shop located at 50 Bulfin Road, Inchicore Dublin which my own family operated for thirty-five years. My first-hand experience with this business provided the impetus to explore the second example examined in this chapter, James Whelan's Butchers from Clonmel in Tipperary. James Whelan's is a very successful butchery business that now employs in excess of Ioo people and whose heritage products are recognized well beyond our nation's shores. Just like M. J. Murphy's, the business began life as a small family butcher shop in Clonmel. When James Whelan's son Pat Whelan took over from his father in the late I990s, this small business shop employed just four people in total. Both butcher shops have something to offer in terms of how we understand the application of a Fourth Space model, but our analysis is particularly focused 
on how, over a relatively short twenty-year period, James Whelan's Butchers managed to successfully harness a range of key heritage attributes for mercantile gain. Due to space and time constraints, we will not be able to analyse these businesses under all five of the Fourth Space strands in Figure 8.3 and we must limit our analysis to Strand I and Strand 2 of the model.

\section{J. Murphy's Butchers, 50 Bulfin Road, Inchicore, Dublin}

In 1963 my parents returned home from Canada after a number of years abroad. Soon after, they purchased and opened M. J. Murphy's Butchers at 5o Bulfin Road, Inchicore, Dublin 8. The small flat above the shop was to become our family home for the next ten years and the shop would remain our family business for the next thirty-five years. My father Michael J. Murphy started working as a butcher's apprentice at the tender age of twelve, served his time in Ireland and travelled over subsequent years with his craft through both the UK and Canada. Throughout a career that spanned more than fifty years he became an extremely skilled practitioner. During my early teens, I recall how every couple of days he would leave the shop and go down to Red Meats Abattoir in nearby Clanbrassil Street to hand-select cattle, pigs and lambs for delivery the following day. These animals would be hung on heavy racks in the shop. They would be skilfully broken down in the shop in the front of the counter, in full view of the customers, before being carried into the walk-in fridge where appropriate ageing techniques and monitoring would ensure meats of the very highest quality. Twice a week we would render down beef suet in a boiler out the back and prepare our own individually wax-packed beef dripping. I can vividly remember my dad hand rubbing what seemed to us kids like secret mixtures and compounds to brine our own corned beef. We would pickle and hand-pump our own hams in a freezing and bloody pickle barrel that rather weirdly doubled as a fast chiller for large bottles of TK lemonade on hot summer days!

At Christmas, I would accompany my father to my Aunty Lil and Uncle Arthur's small farm in Ladytown, Co. Kildare, where we would hand-select 
live turkeys with individual client needs in mind. Once killed and handplucked in the adjacent sheds by my father's brother Sean and his able team, we loaded the chosen turkeys into our car and drove back home to the shop in Inchicore. The whole family pitched in and we would hang them, finish plucking, clean and dress them ready for customers a day or two before Christmas. Throughout his long career, my father would never have considered himself an artisan butcher or even, I suspect, a craftsman. When I look back now through a more contemporary food lens I can see that the shop at 50 Bulfin Road was built on a strong 'place and story' foundation. Although we used hand-selected local produce that strongly reflected the local region, we would never have used words like terroir. My father wouldn't have even have considered himself an 'an entrepreneur'. He was, in his own words, simply a butcher, a tradesman, a shopkeeper. As a family, we all lived and worked in the shop throughout our teens and in some cases into our early twenties. My family remained anchored to 'the shop' for thirty-five years until it was very reluctantly sold in 1998 due to his ill health. Strong memories of M. J. Murphy's Butchers in Inchicore provide me with the inspiration to interpret food or drink sites in a more contemporary context. I would like to know whether our traditional Irish butcher shop did, as I have long suspected, express a true sense of patrimoine. Words like authenticity, sense of place, story and indeed terroir are now frequently deployed when discussing many aspects of food and drink. Businesses increasingly want to differentiate themselves from others by conveying a true sense of patrimoine as one of their key signifiers. This analysis allows me to explore whether M.J. Murphy's could, in some ways, be described as a Fourth Space.

\section{James Whelan’s Butchers, Clonmel, Co. Tipperary}

The Whelans followed a similar track to my own family experience up until the late 1990 s when their small independent butcher shop in Clonmel found itself employing just four people in total and fulfilling predominantly local 
needs. The Whelans also lived over the original family business in Clonmel and the family were raised as part of that same small shop tradition.

We lived over the town shop. If there was a leg of lamb needed in Oakville, I went on my bike to drop it over. This was a continuum of family life. We ran a quality butchers and it was understood that this was part of who we were. ${ }^{10}$

The similar background stories of M. J. Murphy's of Inchicore and James Whelan's of Clonmel part company in 1999. A year after my father sold our family shop, Pat Whelan returned home to Clonmel from Dublin, where he had enjoyed a successful business career to take over the small family business. In the space of twenty years, Pat has taken this once traditional Irish butcher's shop on a journey that has seen it develop and fully integrate its adjoining farm and abattoir. It would go on to forge links with iconic Irish retailers such as Avoca and would open James Whelan's butcher's shops in Monkstown and Rathcoole. It would become an early adopter of online technology and would promote its local produce online throughout Ireland and the UK. It would develop heritage products that would be recognized as expressions of Irish identity throughout Ireland and beyond. The business has just recently partnered with Dunnes Stores and has opened three high-end butcher stores in Dunnes outlets. James Whelan's Butchers now employs ino people across all of its businesses and despite recent structural changes Pat himself continues to work as CEO of James Whelan's Butchers sitting in partnership with bigger retailers like Dunnes and all the while developing what he frequently refers to as 'a legacy brand'.

My mother would always have preached about the lifetime value of a customer relationship .... I am still running the business that I took over from my parents all Whelan raise the steaks', The Irish Times, ${ }_{13}$ October 2017, <https://www.irishtimes. $\mathrm{com} /$ business/retail-and-services/hooking-up-with-dunnes-stores-helps-butcherpat-whelan-raise-the-steaks-I.325249I>. [Accessed 3 January 20I8]. 
those years ago .... My objective is to make sure that it's a legacy brand that people will recognise around great meat long into the future. ${ }^{11}$

In a sense the drive to create what Whelan refers to as a legacy brand does, by necessity, incorporate the successful communication to the client of an authentic sense of patrimoine. The Fourth Space model provides a framework to help achieve this.

\section{Viewing the Traditional Irish Family Butcher Shop through a Fourth Space lens}

\section{Fourth Space Strand I: Creating a gastronomic identity}

Incorporates a Third Place function

The small family butcher shop is at the very heart of traditional Irish society. Though disappearing in more recent times from its typically perceived rural or semi-rural setting, it is often viewed as an important focal point of the local community, a meeting place, a place in which to gossip, a place where frequent banter is engaged in between staff and clients. From experience, it was a place where regular customers had set family orders that were fulfilled by the family butcher and where weekly supplies were sometimes provided 'on tick', recorded in a small blood-stained notebook until they could be scratched off in pencil when payment was eventually made. Ray Oldenburg has written extensively on what he refers to as the 'Third Place', and this attribute is an important element in our Strand $\mathrm{I}$ analysis.

A Third Place is a place that exists outside of both the home (the First Place) and the work environment (the Second Place). Oldenburg is keen

II Brendan Byrne citing Pat Whelan 'Pat Whelan-Building a Legacy Brand in Butchering', <http://www.ThinkBusiness.ie>, N. D. <https://www.thinkbusiness. ie/articles/pat-whelan-butcher/>. [Accessed 5 January 20I8]. 
to stress that Third Places 'exist on neutral ground and serve to level their guests to a condition of social equality'. ${ }^{12} \mathrm{He}$ feels that Third Places are in short supply in America, for example, which forces one to look to Europe, where he believes Third Places are well-catered for. He suggests that in the absence of an informal public life, Americans are denied those means of relieving stress that serve other cultures more effectively'. ${ }^{13}$ The essence of Oldenburg's argument is that Americans must look to European culture to find examples of successful Third Places:

Thus, while Germans relax amid the rousing company of the bier garten or the French
recuperate in their animated little bistros, Americans turn to massaging, meditat-
ing, jogging, hot-tubbing or escape fiction. While others take full advantage of their
freedom to associate, we glorify our freedom not to associate.

Oldenburg's examples of good Third Places include the English pub, The French Café and the German/American beer gardens, but one could argue that there are many aspects of Oldenburg's Third Place that might also apply to a local family butchers of the traditional variety. Oldenburg enumerates a range of phenomena that qualify a location to be classed as a Third Place. They share the following traits:

I. The Third Place has to be on neutral ground.

2. The Third Place is a leveller.

3. Conversation is the main activity.

4. Regular customers are key.

5. As a physical structure it often has a low profile.

6. The mood is playful.

7. It acts as a home away from home. ${ }^{15}$

Many of these criteria fit with the role of the traditional local family butcher shop and though obviously not in the same category as the French Bistro or

I2 Ray Oldenburg, The Great Good Place, 42.

I3 Oldenburg, Io.

I4 Oldenburg, IO.

I5 Oldenburg, 20-42. 
English pub from a personal interaction/hospitality perspective it would seem eminently qualified to be considered one of Oldenburg's Third Places. Indeed, if a food or drink site wishes to convey to visitors its true sense of patrimoine the traits identified above will help facilitate an appreciation of that sense of cultural heritage among a variety of audiences.

Provide authentic people

The small traditional local butcher shop was always typically staffed by local people. Often, as in my own case, the butcher and his family lived over the premises, participated in and was a key member of the local community. Frequently local teenagers were employed during school holidays and unlike larger retailers rarely were staff brought in from outside the area. Often immediate family members and spouses were trained up to work in the family business. There was frequent local banter between staff and customers with the result that the shop developed a reputation for having the 'craic' with the customers. Grantham ${ }^{16}$ suggests that 'having the craic' has become the quintessential term among the Irish for having a good time. Some would contend that the 'craic' in an Irish context can only be achieved by having local Irish staff with an innate sense of hospitality and warmth. From memory, this is very true of staff/customer relations in the shop growing up. It is an intangible aspect of Irish culture that is very difficult to plan for or structure. Visitors from abroad have always associated Ireland as a place where the Irish welcome could be guaranteed. So successful was this association in the past that we exported the culture of that welcome across the world. It is difficult to describe the intangible hospitality and warmth that one associates with a true Irish welcome and yet without these qualities it is difficult to see how any local butcher shop can become a true Fourth Space. This particular strand is obviously related to the previous concept of Third Place in that without an authentic Irish welcome the other aspects of Third Place are difficult to express.

I6 Bill Grantham, 'Craic in a box: Commodifying and exporting the Irish Pub', in Journal of Media and Cultural Studies, 23 (2) (2009), 257. 
James Whelan's shop also provides high quality service which is fundamental to its success however we must note that success and expansion has the potential to dilute an otherwise authentic family welcome and experience. One of the consequences of an expanding business is that one can no longer expect to be served by a family member when visiting the family butchers. A family business such as Whelans that has managed to move beyond its original Clonmel incarnation must by necessity work much harder to maintain a traditional family approach through the qualities and attributes of the staff it employs. James Whelan's does quite well in this regard but inevitably a certain personal identity is lost as the business grows beyond the personal embrace of the immediate family.

Conveys the story of place

The traditional family butcher shop typically provides locally sourced produce that reflect the place its situated in. This was always true of family shops who produced their own sausages, pudding, beef dripping, etc., on site. It was certainly true of M. J. Murphy's in Inchicore. The fact that such products and processes were frequently produced under the gaze of clients, young and old, also added to the rich story of place that these traditional shops revelled in. Modern supermarket butcher's counters have to a large extent forgone this tradition, and now little skilled work is carried out on-site and produce tends to arrive pre-cut and prepackaged thus detracting from the sense of place associated with meats produced on site. Traditional butcher businesses like James Whelan's are keen to take the story of place even further by using only their own livestock from their own farm, processed through their own abattoir. They frequently stock other locally made produce from chutneys, jams, eggs and potatoes to homebaked breads and goods which again reflect the authentic story of their place. Walls and counters are often adorned with pictures and objects associated with local sports teams and local events, etc. The shop window, in many ways, acts as a community notice board for local interactions. The business is often a key supporter of such events and as such acts as an important part of local communities. All of these elements contribute towards the story of the place the butcher shop is 
located in. They anchor the shop to its place which in turn accentuates the associated sense of patrimoine that the site conveys.

Acts as a cultural ambassador

Whelan's Butchers has become renowned, both in Ireland and abroad, for its uniquely Irish award-winning product 'Beef Dripping'. They have taken what was once a very traditional butcher's product, followed an old family recipe and re-energized the product for both the domestic and international market. Like Irish whiskey and Guinness, such products can be especially powerful in conveying a sense of Irishness when associated with a family heritage.

According to Irish Times food writer Marie Claire Digby (2015):

Whelan's winning product, beef dripping made in Clonmel from suet from his grass-fed Irish Angus and Hereford beef, rose to the top from 10,000 entries in the annual awards, and Whelan says he created it with 'more than a little guidance' from his mother. ${ }^{17}$

The links between local family food businesses and Irish identity are strong and in recent years the expansion of locally produced products that reflect the place from which they came has also influenced how people abroad view our gastronomic identity. Such commodification of Irish gastronomic culture has managed to successfully expose Ireland's sense of place to people both living in and outside of the country. Though not always positive, this 'sense of place' has impacted on the image of Ireland and the Irish. One might reasonably ask how interactions with this type of commodified sense of identity can encourage people to form a long-lasting bond with a particular region/place and how this might colour their attitude to products particularly associated with that region. It is the consumer's perception of award-winning products like Whelan's Beef Dripping that has the Ireland' The Irish Times, 8 September 2015 <https://www.irishtimes.com/life-andstyle/food-and-drink/irish-butcher-s-beef-dripping-wins-best-food-product-in-ukand-ireland-I.2344248>. [Accessed I2 December 20I7]. 
potential to shape attitudes to a place and influence them in positive ways. The beef dripping itself is an interesting 'heritage' product in that it was traditionally very common for small family shops to produce their own beef dripping; indeed, it was one of the jobs allocated to my brothers and I when working in the shop. This practice died out in recent years but James Whelan's revived this traditional product and brought it to new markets when he promoted his award-winning beef dripping across the UK and Ireland. By locating satellite shops in places like Avoca Hand Weaver's in Rathcoole and Monkstown he again aligned his produce with a heritage brand that is synonymous in retail terms with reflecting Irish culture to tourists and domestic customers alike thus fulfilling an important cultural ambassador role.

\section{Fourth Place Strand 2: Providing a sense of place/regionality}

Emphasizes place of origin/regionality

Place and a sense of belonging to that place are essential ingredients when striving for patrimoine. The promotion of cultural heritage by necessity requires such heritage to be connected to a particular region or place. It is clear that most traditional family butchers reflect this reality to varying degrees. However, what makes some butchers different is a consistent message that their produce is regional and overtly reflects where it comes from, thus offering an authentic sense of terroir. This was reflected in M. J. Murphy's, as described earlier, but was never really capitalized upon, perhaps because the business existed in a more traditional era where many commercial products sold expressed a sense of place. It was a period of fewer imports and more home-produced goods. In a sense, place integrity was expected through circumstance. James Whelan's business, on the other hand, thrives in a much more open economy, one where homogenous and generic goods flood the market. To compete James Whelan's clearly reference 'place and regionality' with almost all of their products. In cases where they don't supply from their own local farm, they are still keen to emphasize the place and region in the pursuit of gastronomic credibility. 
French attitudes to place and regionality have long been at the forefront of gastronomic culture. The strength of the Appellation Contrôlée laws that were first introduced in 1935 formed an essential bedrock for lots of placebased foods. Ireland is only now beginning to learn from French attitudes to place and regionality in terms of our food and drink products. The European system of place classification, where products are certified and labelled as having a protected designation of origin (PDO) or a protected geographical indication (PGI) is only recently gaining traction in Ireland. Like the Appellation Contrôlée system PDO and PGI classifications allow for food and drinks to be aligned with particular places and regions once certain strict criteria are achieved and a quite complex application procedure is successful. Currently France has I03 separate food products registered which have achieved PDO designation while Ireland only has three. ${ }^{18}$ However, increasingly Irish food producers are beginning to understand the importance of having recognized certification that formally ties foods to particular places. In 2013 a collection of Waterford bakers were awarded PGI designation from Europe for producing their unique and traditional 'Waterford Blaa' breads and there we will undoubtedly be more Irish food products seeking similar place and process certification from Europe in the coming years. ${ }^{19}$

Avoids being an 'absolute fake'

Authenticity is key when any food business is attempting to identify with their 'sense of place'. Though difficult to define there are increasing examples of food and drink businesses attempting to align themselves with stories that are quite thinly veiled in reality. Attempts to use falsely created back

I8 All European products that have achieved PDO and PGI stayus are detail of the European Commission's Agriculture and Development site which is available at: <http://ec.europa.eu/agriculture/quality/door/list.html?\&recordStart=0\&filter. dossierNumber $=\&$ filter.comboName $=\&$ filterMin.milestone _ mask $=\&$ filterMin . milestone $=\&$ filterMax.milestone__mask $=\&$ filterMax.milestone $=\&$ filter. country $=$ FR \&filter.category $=\&$ filter.type $=$ PDO \&filter.status $=$ REGISTERED $>$. [Accessed 2 January 2018].

I9 Marie Claire Digby, 'Waterford Blaa awarded special status by EU', The Irish Times, I9 November 2013. [Accessed 2 January 2018]. 
stories should be treated with care and often producers might be better served by emphasizing more authentic elements of story even if such story is more contemporary in nature such as the story of the ingredients used, the story of the people who supply the product or the story of the processes used to make the product.

James Whelan's does this to great effect while maintaining a sense of authenticity due to the verifiable links that the contemporary business has with five decades of butcher history. Firstly, the direct and consistent link with the original family butcher shop in Clonmel provides the brand with immediate status. Secondly, the link with their own farm and abattoir substantiates this sense of authenticity. There are other less obvious authentic story elements that are particularly interesting. As part of their design in their butcher outlets in both Avoca locations, and more recently in Dunnes of Cornelscourt, they have presented their staff butcher's skills in a very interesting manner. Unlike more traditional butcher shops, the skilled aspect of the production is clearly visible to the consumer, thus providing authenticity in terms of the meat produced and skills used on site. The butcher faces the consumer through a floor to ceiling glass window which could almost be described as a viewing stage. Behind the viewing window, three butchers work on three separate cylindrical blocks ensuring that no customer is left in doubt when it comes to the treatment of their meats and the creation of their often quite artistic presentation. Modern versions of less authentic butcher shops provide no visibility at all with regard to the preparation of meat products, which are frequently brought into the shop pre-prepared and pre-packaged at a factory location. Such authenticity of approach was always evident in traditional Irish butcher shops such as M. J. Murphy's, when all skilled handling and preparation of meat products was carried out in full view of the clients. James Whelan's have simply taken this concept to a new level thus enhancing their own sense of authenticity.

Provides an educational medium/enables decodification

One of the particular challenges faced by many food and drink products rests in the codified nature of the product and our Fourth Space approach attempts to address such challenges by focusing on opportunities for 
educational engagement with the product in question. French appellation contrôlée wines provide perhaps our best example of the need for such educational engagement. Aside from the obvious language differences, quite complex legislation and labelling systems can often pose problems for consumers when it comes to interpreting a French wine fully. Grape varieties are traditionally not mentioned on the label and the complexities of their appellation contrôlée systems are often not apparent. Terms such as Premier Cru and Grand Cru mean different things in different regions and represent other aspects of the wine's story that need de-codification. For the individual to fully appreciate such a culturally charged product, it is necessary to have various levels of wine knowledge, and there has been a considerable uptake in terms of formal beverage education courses in recent years. Though arguably not quite as complex as French wine, the whole area of the meats we eat also has layers of understanding that consumers find attractive. In his introduction to the book Distinction, Pierre Bourdieu suggests, when referring to a work of art, that 'a beholder who lacks the specific code feels lost in a chaos of sounds and rhythms, colours and lines, without rhyme or reason' ${ }^{20} \mathrm{He}$ is suggesting that a piece of art or music can be consumed on different levels. Without the appropriate code, Bourdieu maintains that:

He cannot move from the 'primary stratum of the meaning we can grasp on the basis of our ordinary experience' to the 'stratum of secondary meanings', i.e. 'the level of meaning of what is signified', unless he possesses the concepts which go beyond the sensible properties and which identify the specifically stylistic properties of the work. ${ }^{21}$

A similar approach might be suggested with regard to understanding meats and the entire butchery process that has been in a sense hidden from view as the traditional Irish butcher shop has faded from prominence. Increasingly consumers are separated from the meat production process and have become familiar only with the finished product which is

20 Pierre Bourdieu, Distinction: A Social Critique of the Judgements of Taste, trans. Richard Niece (Abingdon, Oxon: Routledge Classics, 2010), xxv. 
sometimes deliberately disguised to hide its true origins. James Whelan's butchers have been very innovative in the way they have introduced elements of formal and informal education into their engagement strategies. Firstly, they have begun running butchery course targeted at the lay market that encourage consumers to become proficient in the art of butchery. These three hour programmes are delivered in relaxed but educational manner on site in their butcher shops to small groups of IO/I2 people. A typical course itinerary includes the following topics: Meet and Greet, Overview of James Whelan Family History, Knife Play, Celebration of Pork, The Sweet Secrets of Beef, Chicken at its best, Nibbles and Natter. ${ }^{22}$

Other examples of informal education can be found in the very transparent way that the James Whelan's butchers carry out complex butchery task on customer-centric display blocks as previously described. They have also been extremely innovative in their development of the Butcher Academy concept which has recently provided more formal butcher training to young career butchers that they have taken on. As outlined in the quote below such educational strategies are deliberately engaged with a view to perpetuating the legacy of the butchery business:

But he has other strategies in play to help him reach his goal of turning James Whelan Butchers into a 'legacy brand' in Ireland. One has been to establish a 'butchery academy' under the brand, a move which he feels will also help protect the business against skills shortages in the future. ${ }^{23}$

By passing on the traditional skills of the butcher in the James Whelan's Butchery academy Pat Whelan is ensuring that the traditional craft of butchery stays relevant. By developing their own educational framework, they are also enhancing a sense of patrimoine because this framework is being used to ensure that the unique James Whelan's butchery ethos is perpetuated.

22 This is the events course outline for their next upcoming butchery demonstration on 26 February 2018 to be held in the butcher shop, <http://www.jameswhelanbutchers. com/info/butchery-demonstrations/ $>$. [Accessed 8 February 2018].

23 Killian Woods, 'Why this Tipperary butcher sold his five-decade-old family business to Dunnes', The Journal.ie, <http://www.thejournal.ie/james-whelan-butchersdunnes-stores-2-3713094-Nov2017/>. [Accessed 20 December 2017]. 
Allows for other food and drink perspectives

Given the gastronomic developments that have occurred in Ireland in recent decades, it is very difficult to envisage any individual food product in isolation and other foods and drinks must now form part of any Fourth Space strategy. It is interesting to note that modern butchers like James Whelan's have started to align themselves with other food and drink categories not traditionally associated with the butcher's domain. Many have broadened their ranges to include high-end deli goods such as jams, chutneys, gourmet cheeses, sauces and oils. Examples from James Whelan's include innovative ancillary food products such as their 'slim line meats range', and their extensive 'restaurant-like' party-to-go menu for outside catering. Some beverage product categories are also natural bedfellows for different meats and there are other examples within the traditional butcher shop arena such as Nolan's Butchers in Kilcullen, Co. Kildare, who offer extensive high-end wine selections within the confines of their traditional butcher shop, as well as the expertise to describe and match those wines to various meats.

\section{Conclusion}

Meat is a complex and culturally laden product. It offers more than simple proteins that we consume for nourishment. At its worst meat can be heavily processed, uniform and cynically lacking in authenticity. At its best such foods are a combination of people, place and story. We have seen successful examples throughout this chapter of Fourth Space approaches in terms of the traditional Irish butcher shop. I argue here that in order to position a food business using a Fourth Space model that business needs to emphasize the benefits of an enhanced sense of cultural heritage. M. J. Murphy's held within the confines of its walls many elements of what we now describe as terroir. It had the benefits of a family heritage tied to my father that spanned fifty years. The skills, the processes, the products, the authentic 
people were indeed all present at 50 Bulfin Road Inchicore but such a sense of patrimoine was never really exploited. The James Whelan's example in this chapter tells a very different story. One that started out in the same way as M. J. Murphy's but one who came to fully understand the importance of Fourth Space engagement. Due to time constraints, we limited our analysis to just the first two strands of our Fourth Space model but other strands reveal additional approaches that involved similar cultural engagement strategies. These include the early adoption of online technology to enhance the business story and an appreciation of cultural economy through the release of two beautifully produced and illustrated butchery books by Pat Whelan himself, An Irish Butcher Shop ${ }^{24}$ and The Irish Beef Book. ${ }^{25}$ To make use of a truly successful Fourth Space strategy, one must not be driven solely by the desire for monetary success. The true passion of the individual artisan operator must shine through. The combination of the product's 'place and story' elements are capable of creating a very real bond between product and customer and James Whelan's Butchers, through the unique vision of Pat Whelan, have managed to do this.

In a world where profit has become the only real key driver of success, it is perhaps unlikely that every single aspect of an authentic Fourth Space can be realized. As soon as the strands of that Fourth Space are seen as a route to monetary gain, the game is lost. The magical spell that binds the person to the product's authentic 'place and story' can start to loosen. We live in a post-truth world filled with 'fake news' and 'alternative facts'. In order for any food or drink product to maintain its standing, 'place and story' have got to be authentic and true to their origins. Marketing experts will continue to dilute such elements in the understandable pursuit of profit. There is less and less reference to 'real' people and the story associated with their place, unless it fits in with a preordained marketing back story. It seems to matter less and less whether the story is real or the place exists at all. On reflection, when I overlay our Fourth Space approach on to M. J. Murphy's, I am thankful that 'the shop' stayed true to its original

24 Pat Whelan, An Irish Butcher Shop (Cork: The Collins Press, 2010).

25 Katy McGuinness and Pat Whelan, The Irish BeefBook (Dublin: Gill and McMillan, 2013). 
ethos of providing a quality local product to a local community. It was a traditional butcher shop that fulfilled but never capitalized on many of the Fourth Space strands discussed here. While it was strong in some quarters and weaker in others it was, I believe, authentic and possessed a terroir of its own.

True Fourth Spaces are becoming relatively rare given our recent economic history but there are now real signs of a revival. There is evidence of a gastronomic world willing to at least consider holding more dearly the role that people, place and story have to play in our food and drink culture. We have had the rise of the Slow Food movement spreading to all parts of the globe, including Ireland. There has been an increase in organic food and drink production as people seek out surety about their ingredients and information on their food's origins. The popularity of independent craft breweries, gin and whiskey distilleries is on the increase. A new locavore has emerged who expresses a desire to know exactly where their food and drink has come from with an almost evangelical insistence that it be steeped in the local. As these trends emerge, large producers are already seeking to appropriate the smaller producer's people, place and story status. Small operators like the traditional family butcher shop are being subsumed so that larger multinationals can create 'impressions' of individuality. These large global entities desperately need to be associated with 'true' stories. They often maintain façades of authenticity, but as soon as they subsume an individual operator into their collective terroir brand, any sense of patrimoine is lost. It is perhaps through authentic culturally driven interpretations of Fourth Spaces like James Whelan's Butchers that real associations between products, people and place can be sustained and nurtured in an increasingly competitive environment. The idea that the traditional family butcher can provide patrimoine in such a world may yet prove to be one of the few ingredients that allows true 'distinction' in an ever-shrinking world of sameness. 


\section{9 'Butter them up': When Marketing Meets Heritage - The Case of Irish Butter in Germany}

When shopping for food and grocery products in supermarkets (Rewe, Tegut) and discount stores (Aldi, Lidl or Norma) in Germany, consumers are presented with a large variety of butter packs. Curiously though, along the German traditional Markenbutter or Deutsche butter, customers can also find Kerrygold Irische butter, Butter aus Irland as it says, and a good number of other packages with an Irische butter label and, sometimes, truly Irish-sounding names such as O'Grady. Why is Irish butter sold in Germany? And why are there so many other products with an 'Irish butter' label on them, with a golden foil packaging that is remarkably similar to Kerrygold's ?' A short Internet search offered a partial answer: surprisingly, Kerrygold butter has been retailed in Germany since the early I970s, and has since reached an 'iconic' status. ${ }^{2}$ It is a bestseller, retailing at a premium price, with weekly sales of 3 million packs in $2016{ }^{3}$

How could one explain that butter from Ireland would be a top seller in Germany? Could it be possible that German consumers would be less concerned with their own dairy industry when people and governments alike value country of origin (COO) labels, and are preoccupied by the quality of food? Is the German dairy market much more open than its French counterpart, or is milk production in Germany too small, calling for imports of dairy products from abroad? Or is it, after all, a matter of tradition and

I Derek Scally, 'Copycats aim to bite into Kerrygold share of German butter market', The Irish Times, I 8 March 2016.

2 Joe Dermody, 'Iconic butter a bestseller abroad', Irish Examiner, io April 2013.

3 S. Cummins, 'Ornua expects Kerrygold to become a billion euro product in the coming years', Agriland website, <http://www.agriland.ie/farming-news/ornuaexpects-kerrygold-to-become-a-billion-euro-product-in-the-coming-years/ $>$. [Accessed 9 May 2016]. 
expertise? For example, is German consumers' longing for traditional and authentic products being filled by Ireland's older know-how in butter? Mary Ann Bolger argued that the advertising of Irish exports in the 1960 s with Kerrygold provided a form of 'tourism without travel' for British consumers, Kerrygold acting as an authentic signifier of Ireland because the ads said that it was 'made of Ireland'. ${ }^{4}$ As Kerrygold has become 'synonymous with Ireland' for many German consumers, ${ }^{5}$ what sort of Ireland is marketed when they purchase what they might see as a living piece of Ireland's patrimoine?

\section{Is Irish Butter a Symbol of Irish Culture?}

Beer culture in Belgium, the gastronomic meal of the French as well as the music and dance of the merengue in the Dominican Republic have all been entered lately on the UNESCO's representative list of the intangible cultural heritage of Humanity. Surprisingly, neither Irish traditional music nor Irish traditional cuisine, nor one of its much used ingredients, butter, seem to be anywhere close to making that list. If Irish butter is sold under a particular Irish label to German customers, does this mean that although unrecognized, it still represents some sort of Irish gastronomic and cultural heritage?

If one understands heritage as a reference to one's ancestors or some distant past, then Irish men and women could say that Irish butter effectively belongs to some Irish heritage. It could be part of Ireland's patrimoine as butter has been produced in Ireland and exported for centuries. Heavily salted butter, particularly made on farms in the south and south-west, ${ }^{6}$ was InPrint $\mathrm{I}, \mathrm{n}^{\circ} \mathrm{I}$ ( 19 November 2013), <http://arrow.dit.ie/inp/voli/issi/7>. Amy Forde, 'Demand for Kerrygold sees ornua invest $€_{\mathrm{IO}} \mathrm{m}$ in German expansion', Agriland website, <http://www.agriland.ie/farming-news/demand-for-kerrygoldsees-ornua-invest-eıom-in-german-expansion/>. [Accessed II February 2017].

6 Cormac Ó Gráda, 'The Beginnings of the Irish Creamery System, I880-1914', Economic History Review, vol. 30, 1977, 285. 
one of Ireland's main exports until the late nineteenth century, and trade was organized through a commercial network including farmers and butter merchants. The Cork Butter Market was 'an internationally known institution [...], with its own grading system' organizing export markets in Britain, North America and the Continent, ${ }^{7}$ while other butter markets catered for the rest of the country (Limerick, Tipperary, Clonmel and Kilkenny). ${ }^{8}$

In an attempt to make an inventory of traditional foods among EU members, Cathal Cowan and Regina Sexton looked at Ireland and found that butter was referred to as 'country butter' or 'farmhouse butter'. Before writing a brief history of butter and insisting on its role as a staple element of Irish diet, both authors felt the need to add in their introduction that the GEIE (Groupement Européen d'Intérêt Economique) Euroterroirs which had commissioned the study:

did not accept some of our entries in their report to the EU as they argued that some of the products [had] no tradition, or no specific tradition in Ireland that [was] different from other countries. The former was argued for farmhouse cheeses (processes not old enough) and the latter for cabbage, onions, apples, tea and butter.

But if Irish butter and other products were not part of Ireland's traditional food, both authors agreed to retain these entries in their final draft 'as such an approach [was] helpful to the ongoing debate on protection'. ${ }^{10}$ Other publications do not expand much on the possible recognition of butter among Irish food. Bríd Mahon's Irish Food for example does not contain any mention of butter, ${ }^{11}$ while Mártín Mac Con Iomaire only insists on butter as a basic ingredient for Irish recipes and something served alongside jam with

7 An Bord Bainne/The Irish Dairy Board, The First Io Years (Dublin, Irish Dairy Board, 1971).

8 John Foley, 'The Irish Dairy Industry: a Historical Perspective', Journal of the Society of Dairy Technology, vol. 46, no. 4, 1993, I25.

9 Cathal Cowan and Regina Sexton, Ireland's Traditional Foods. An Exploration of Irish Local and Typical Foods and Drinks (Teagasc, The National Food Centre, 1997), xi.

IO Ibid., xi.

II Bríd Mahon, Irish Food (Tallaght: Folens, I977). 
scones for example. ${ }^{12}$ In other publications looking at traditional products, Irish butter is not described as central to Irish culture. In The Taste of Ireland, Tamsin Pickeral focused on recipes and photos by provinces, ${ }^{13}$ while Elizabeth Fitzpatrick and James Kelly's recently edited volume on the history of food and drink in Ireland does not place butter as an essential element of Irish culture, apart from its presence in the diet of Irish men and women through history, nor does it identify butter with Irish culture. ${ }^{14}$ All these publications merely point to the presence of butter in Ireland, a dairy product which has been produced for ages in Ireland, is central to the Irish dairy industry, and essential as an ingredient in the making of Irish traditional recipes. But contrary to the examples of Connemara Hill lamb or the Waterford Blaa, Irish butter has not reached a particular status. ${ }^{15}$ The closest Irish butter comes to something traditional relates to the Irish dairy industry's 'tradition of exporting. ${ }^{16}$

In Germany, the reverse seems to be true. In June 20II, Dublin-based consultancy firm Amárach reported that Ireland was most commonly perceived by German consumers as a green island with beautiful scenery and unspoiled nature, and butter. ${ }^{17}$ The relevance of such keywords was confirmed by the results of an opinion poll published in August 2012 on what German and Irish peoples thought about one another. Commenting in The Irish Times, Stephen Collins wrote that 'the majority of Germans view Ireland through

I2 Mártín Mac Con Iomaire, 'Ireland', in K. Albala (ed.), Food Cultures of the World Encyclopedia (Westport, CT: Greenwood Press).

I3 Tamsin Pickeral, The Taste of Ireland. Landscape, Culture and Food (London: Star Fire, 2008).

I4 Elizabeth Fitzpatrick and James Kelly (eds), Food and Drink in Ireland (Dublin: Royal Irish Academy, 2016).

I5 Only four Irish products are registered with the PGI (Protected Geographical Indication) label within the EU: Clare Island Salmon, Connemara Hill lamb, Waterford Blaa and Timoleague Brown Pudding. Strangely, in France, only the Bouchot mussels are identified as TSG (Traditional Speciality Guaranteed). European Commission, Agriculture and Rural Development, DOOR database. Peter Foynes, Colin Rynne and Chris Synnott (eds), Butter in Ireland. From Earliest Times to the 2Ist Century (Cork: Cork Butter Museum, 20I4), 9.

17 Amárach Research, 'Selling to the German Consumer', An Amárach Research Briefing, June 20II, 3 I. 
green-tinted spectacles with images of beautiful countryside, farm animals and wet weather predominating'. ${ }^{18}$ 'A whopping 60 per cent of Germans, when asked what came to mind when they thought of Ireland', he wrote, 'came up with rustic images of a green and beautiful island, while another 17 per cent mentioned agriculture and farm animals. ${ }^{19}$ The 20 II study also confirmed that Kerrygold and Bailey's were among the most often mentioned products, with three in four German people having heard of these brands. ${ }^{20}$ When questioned about Ireland and what came first to their minds, German respondents in the 2012 study first mentioned, in this order, the countryside and landscape, pubs and alcohol, agriculture and farm animals, the fact that it was an island, the weather, and butter, Kerrygold butter. ${ }^{21}$ Surprisingly, 'eleven per cent mentioned butter as the first thing coming to mind about Ireland, ${ }^{22}$ though ironically both studies confirmed that only a small minority of German interviewees had visited Ireland, Io per cent for the Amárach study, 9 per cent for The Irish Times opinion poll of 2012. The Amárach study argued that the 'Made in Ireland' label was likely to positively influence German consumers' purchasing decisions. ${ }^{23}$ Irish Times columnist Stephen Collins went further, suggesting that such results could have been influenced by the Kerrygold brand itself. ${ }^{24}$

Interviewed in 2013 for the Irish Farmers Monthly, Anne Randles, Secretary and Director of Administration at the Irish Dairy Board (IDB), explained that 'Germany [was] Europe's largest dairy producer' and with high milk production volume, it made 'the success of Kerrygold there all the more remarkable'. ${ }^{25}$ Recent data show that Germany produces enough milk

I8 Stephen Collins, 'Rolling, rainy pastures and butter: how Germans see Ireland', The Irish Times, 27 August 2012. See also S. Collins 'Germans buttered up to view Ireland as rural idyll, poll finds', The Irish Times, 27 August 2012.

I9 S. Collins, 'Rolling, rainy pastures and butter'.

20 Amárach Research, 'Selling to the German Consumer', 32.

2I S. Collins, 'Rolling, rainy pastures and butter'.

22 Ibid.

23 Amárach Research, 'Selling to the German Consumer'.

24 S. Collins, 'Rolling, rainy pastures and butter'.

25 Quoted in 'Building on the Kerrygold Success', Irish Farmers Monthly, II November 2013, 46. 
to supply its population in addition to producing various dairy products as well. In 2015, Germany had the largest milk collection by dairies in Europe, representing 2I per cent of the EU-28 total cows' milk collection, whereas Ireland represented 4.3 per cent. ${ }^{26}$ At the same time, Germany's production of butter in 2015 was also the largest among EU countries as Figure 9.I shows.

Figure 9.I: Butter production in selected EU countries ( $1,000 \mathrm{t})$ in 2015

\begin{tabular}{|l|c|}
\hline Germany & 509.49 \\
\hline France & $444.0 \mathrm{I}^{\mathrm{P}}$ \\
\hline Netherlands & 236.24 \\
\hline Ireland & $222.90^{*}$ \\
\hline United Kingdom & 149.70 \\
\hline Denmark & 93.07 \\
\hline
\end{tabular}

Source: Eurostat Database (2017) - * 2014 / P provisional

So, the core question arises as to why does Irish butter, while not typically exemplifying Ireland's culture, appear via Kerrygold butter to wear a badge of Irish identity for German people? In other words, how is it so much associated in the minds of Germans with Ireland? And what sort of Irish identity does it present?

\section{Kerrygold Irish Butter: An Export-Oriented Product to Reach the British Market}

Bolger has written that in Ireland, butter was for long sold as a commodity, not as a brand. ${ }^{27}$ Consequently, prior to the launch of Kerrygold, Irish butter was not identifiable in overseas markets. ${ }^{28}$ There was no particular market-

26 Eurostat, Milk and Milk Product Statistics, Data portal, 2015.

27 M. A. Bolger, 'Buttering Up the British: Irish Exports and the Tourist Gaze', 84.

28 J. Foley, 'The Irish Dairy Industry: a Historical Perspective', I3 I. 
ing strategy to sell butter, as marketing butter essentially meant selling it through the Butter Marketing Committee or disposing of its surpluses as supplies were not guaranteed. ${ }^{29}$ The Dairy Produce Marketing Act of $196 \mathrm{I}$ provided for the setting up of the Irish Dairy Board or An Bord Bainne, the principal function of which was 'to improve and develop the export marketing of Irish dairy products ${ }^{30}$ outside the State. At the same time, its other objective was to centralize marketing to increase the dairy industry's negotiating strength when selling standardized products. ${ }^{31}$

Supported by a 'persuasive advertising campaign and a strategic marketing plan', ${ }^{32}$ Kerrygold, was then launched on the British market in October 1962 by the Irish Dairy Board ${ }^{33}$ under the leadership of Anthony O'Reilly who had felt the need 'to move Irish dairy exports away from commodity markets and into a value creating brand'. ${ }^{34}$ A specific marketing strategy was implemented to export butter to Britain, and compete with Danish and New Zealand butters, using modern marketing techniques based on market research and analysis of the British consumer's perception of Ireland and Irish food, and a television campaign to communicate the message. ${ }^{35}$ The attempt to launch Kerrygold in Britain was a success. Using the most sophisticated marketing tools available at the time, the Irish Dairy Board turned 'a poorly-regarded Irish food product into a premium brand' ${ }^{36}$

The marketing strategy in Britain was twofold: landscape and tourism were used as essential elements to promote the product, as well as its natural and home-made qualities. The underlying argument was that consumers in Britain 'could experience tourism without travel' ${ }^{37}$ when consuming

\footnotetext{
29 'Preface' in P. Foynes, C. Rynne and C. Synnott (eds), Butter in Ireland, 8.

30 'Milk Board to develop exports', The Irish Times, 6 March $196 \mathrm{I}$.

3I Butter in Ireland, 8.

32 J. Foley, 'The Irish Dairy Industry: a Historical Perspective', I3I.

33 An Bord Bainne, The Bord Báinne Story: Twenty-One Years of Growth in the Irish Dairy Industry (Dublin: An Bord Bainne, 1982), 6.

34 'The Story of Kerrygold', Irish Famers' Monthly, July 2011, 28-32.

35 P. Foynes and P. O'Flynn, 'The Emergence of the Modern Dairy Industry' in P. Foynes et al., Butter in Ireland, I45.

36 Ibid.

M. A. Bolger, 'Buttering Up the British: Irish Exports and the Tourist Gaze', 83.
} 
the product. Even the name of the product was thought of very carefully. It was a name which echoed many things, the famous Kerry landscapes as well as some cultural and historical heritage.

From the very beginning as Lysaght has shown, the strong association between Kerrygold and Ireland was firmly established as the initial slogan made it clear: 'Ireland is Kerrygold Country'. ${ }^{38}$ This catchphrase was reinforced by other sentences chosen to boost Kerrygold's market share in Britain, one of them stating naturalness and quality: 'We take our green and turn it to gold. Kerrygold'. ${ }^{39}$ The advertising strategy of the brand also presented the products as natural dairy products referring to their 'attributes of quality, naturalness and freshness underpinned by images of cows grazing outdoors in the lush green fields of Ireland' ${ }^{40}$ A particular natural endowment has always been part of Kerrygold's message and marketing strategy, inspired by Ireland's natural advantages for dairy farming: 'good soil, mild climate under the influence of the Gulf Stream, moisture bearing South Westerly winds and so on' ${ }^{41}$ When Kerrygold was launched in Great Britain in 1962, the strategy was to emphasize the lush green pastures and the great beauty of the Irish countryside. ${ }^{42}$ As Lysaght has argued, the 'connection between product and landscape, intended to promote Kerrygold butter as a natural product, can also be seen as suggesting that by consuming the butter one can capture the flavours of the landscape, almost as if one had consumed it also. In this way one could vicariously experience the landscape of Ireland', ${ }^{43}$ and thus enjoy a true Irish experience.

Despite its export-oriented strategy, part of its DNA, ${ }^{44}$ Kerrygold butter was later introduced to Ireland, 'anticipating any attempt by other EU producers

Patricia Lysaght, 'Taste Kerrygold, experience Ireland': An Ethnological Perspective on Food Marketing', in Béaloideas, 72 (2004), 6I-90, 72.

Irish Dairy Board, Kerrygold International, I97 I (no. I, no month).

P. Lysaght, 'Taste Kerrygold, experience Ireland', 72.

An Bord Bainne, The Bord Bainne Story: Twenty-one years of growth in the Irish Dairy Industry (Dublin: An Bord Bainne, 1982), I4.

Ibid., 36.

P. Lysaght, 'Taste Kerrygold, experience Ireland', 74.

For example, in 2013, Anne Randles, Secretary and Director of Administration at the Irish Dairy Board argued that 'overall our focus is on the export side. If an alternative 
to exercise their right to sell in the Irish market'. ${ }^{35}$ In June 1972, J. C. McGough, Bord Bainne's Managing Director, announced that it intended to market butter in the Republic under the Kerrygold brand name. ${ }^{46}$ Reaching the home market was strongly associated with Ireland's prospective entry into the EEC to prepare the ground for an increased competition from other European producers, ${ }^{47}$ and make sure that it would also be retailed domestically:

In the past, Bord Bainne provided a marketing service to the dairy industry in export markets only. The board is proud to be invited now to provide this service in the most important market of all [...]. The purpose of [launching] Kerrygold on the home market is to establish a strong brand franchise for Kerrygold prior to Free Trade conditions in the E.E.C. From 1973 onwards, it is thought that Kerrygold will have a firm foothold in the Irish butter market to meet any competition from other national brands. ${ }^{48}$

\section{Kerrygold and the German Market}

As Kerrygold was introduced on the home market, it was also launched in parallel in Germany. In October 1973, an Irish Times headline announced that 'Bord Bainne [was] to sell in West Germany. ${ }^{.9}$ In some ways, it benefitted

product is available on the Irish market, such as Kerrygold spreadable, it has either been supplied directly by the manufacturer or enters the market via a UK retailer's own distribution channel. But, overall, the Irish consumer does not get to enjoy the full range of our Kerrygold products, as they are developed for the export markets'. Quoted in 'Building on the Kerrygold Success', Irish Farmers Monthly, II November 2013.

45 P. Foynes and P. O'Flynn, 'The Emergence of the Modern Dairy Industry' in P. Foynes et al., Butter in Ireland, 146.

46 'Bord Bainne to sell Kerrygold in the Republic', The Irish Times, 2 June 1972.

47 Such a position was also defended by Noel Gilmore, chief executive of the National Dairy Council who 'stressed that Ireland was the most attractive market in Europe for dairy products and Irish manufacturers could expect a severe onslaught of foreign competition'. 'Bid to protect home dairy market opens', The Irish Times, 13 December 1973.

48 'Bord Bainne to sell Kerrygold in the Republic', The Irish Times, 2 June 1972.

49 'Bord Bainne to sell in West Germany', The Irish Times, 22 October 1973. 
from past experience as Kerrygold had been tailored initially for the British market in the early I960s. A distributing partner was found in Germany, Dusseldorf-based co-operative Vereinigung Rheinischer Molkereien (VRM), which would give An Bord Bainne the exclusive rights to distribute and sell butter and cheese from Ireland in the North-Rhine Westphallia and Rhineland - Pfalz areas. ${ }^{50}$ A specific market research was conducted, 'Bord Bainne [having organized] a retail test in 19 branches of the Horten Group, a national chain of department store. ${ }^{51}$ Such an area 'for the board's first brand marketing operation' was chosen, as The Irish Times agricultural correspondent stressed, following 'an extensive research study of market opportunities in Europe carried out by the board in 1972 '. The area, the article went on, had:

a population of seven million people, holds the largest population concentration in Germany $[. .$.$] and has the lowest per capita production of dairy products, thus con-$ stituting the biggest importing area for butter and cheese in Germany. This region also has a higher disposable income than in the south, which makes it a prime butter and cheese consumption area. [...] Germany is the highest priced butter market in Europe $-£_{969}$ a ton, against $£_{7} 62$ in Italy and $£_{455}$ a ton in Britain. ${ }^{52}$

The agreement at the time appeared very much as a strong initiative to get a foothold on the continent and to extend market for Irish butter and other products made in Ireland. Irish butter had to be tailored to the taste of people on the continent, very much as it had been done for the British market earlier on, a specific product for a market, lactic butter:

Bord Bainne is arranging a substantial increase in lactic butter production this year with three major creameries, in order to launch Kerrygold butter on the Continental market. Lactic butter production now represents only a very small proportion of total butter production, and is almost entirely for export to the Scottish and north of England butter market. Bord Bainne is, however, hoping to establish a substantial outlet for Kerrygold on the Continent this year, and is arranging for an increase

50 Ibid.

5I Ibid. See also An Bord Bainne/The Irish Dairy Board, 'German deal marks 'breakthrough' for Irish dairy exports', Kerrygold International, no. 6, May 1973.

52 Michael Browner, 'Kerrygold butter for the continent. To West German market initially', The Irish Times, 7 March 1973. 
in lactic butter production as a result. Unlike consumers in Ireland and the south of England, the Continentals prefer lactic butter (unsalted, cultured butter) to the sweet-cream salted butter consumed in Ireland. [...] Bord Bainne intends to move into the West German market, initially, and later probably into the Italian market. All sales will be of lactic butter. ${ }^{53}$

With a firm foothold in Germany guaranteed by an agreement with a German co-operative, the next step was to launch Kerrygold using the same strategy as with Britain in the previous decade. Joseph C. McGough, managing director of the board thus argued that:

[in] the terms of this agreement with our colleagues in VRM, we undertake to supply dairy products of the highest quality. VRM in their modern and efficient factory can give us the packaging and distribution facilities we need. We [...] will apply the same techniques of advertising and marketing which has made the Irish national dairy brand 'Kerrygold' a trusted dairy name in Britain and in 30 other countries throughout the world. ${ }^{54}$

Marketing was one of the keys to the emergence of Kerrygold on the German market as McGough added that ' [this] combination of high quality produce with efficient marketing will be, I believe, the key to our success in this new market. ${ }^{5}$ Since then, Kerrygold butter has gradually become the most purchased butter in Germany. Over the last decades, the company in Germany

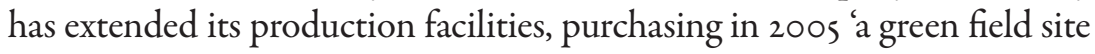
in a business park development in Neukirchen-Vluyn, the access route to which was officially named Kerrygoldstrasse or Kerrygold Street. ${ }^{56}$ And, the range of Kerrygold products has broadened through brand extension since the 2000 s, with a prepacked cheese range ${ }^{57}$ as well as yogurts and Kerrygold Extra, a spread made from butter and rapeseed oil in $2009 .{ }^{58}$

Ibid.

54 'German deal marks 'breakthrough' for Irish dairy exports', Kerrygold International, no. 6, May 1973, An Bord Bainne/The Irish Dairy Board. Ibid., 2.

56 Ibid.

57 Irish Famers' Monthly, 'Kerrygold - still growing in Germany', July $2011,46$.

58 Olive Keogh, 'Buttering up the Germans', The Irish Times, 26 November 2012. 
Kerrygold's German Website: When Marketing Meets Heritage and Tourism

The main title of the page is 'Kerrygold - Das Gold der grünen Insel'. The strong association between the product and Ireland goes through the island of Ireland and starts from the very beginning with the logo on the top left (see Figure 9.2). ${ }^{59}$

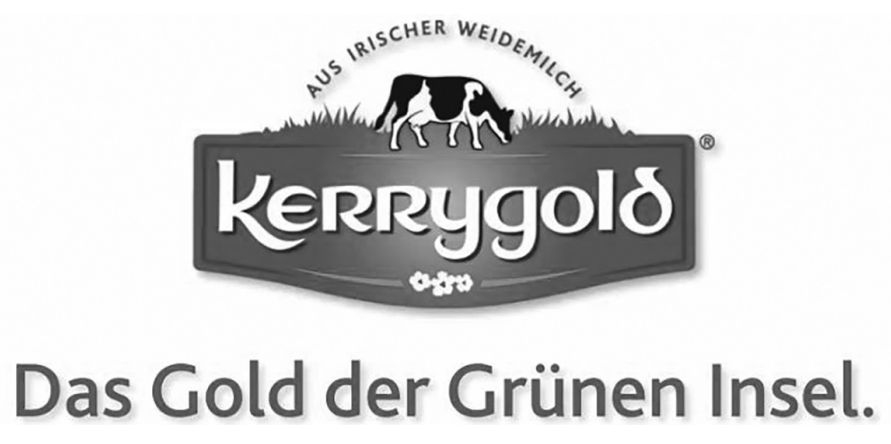

Figure 9.2. Detail of Kerrygold logo

As viewers proceed on the page, they encounter a presentation of different products sold in Germany. That very first page contains some information below the fold with articles itemized by a selection of photo-montages with cows grazing freely and the hills in the background, the sea, the green meadow, or the coast, all reminders of the Irish landscape. A young farmer on an old stone wall is also present, offering an additional touch of authenticity (see Figure 9.3).

59 All references are taken from the Kerrygold website, <http://www.kerrygold.ie>. [Accessed September 2017]. 


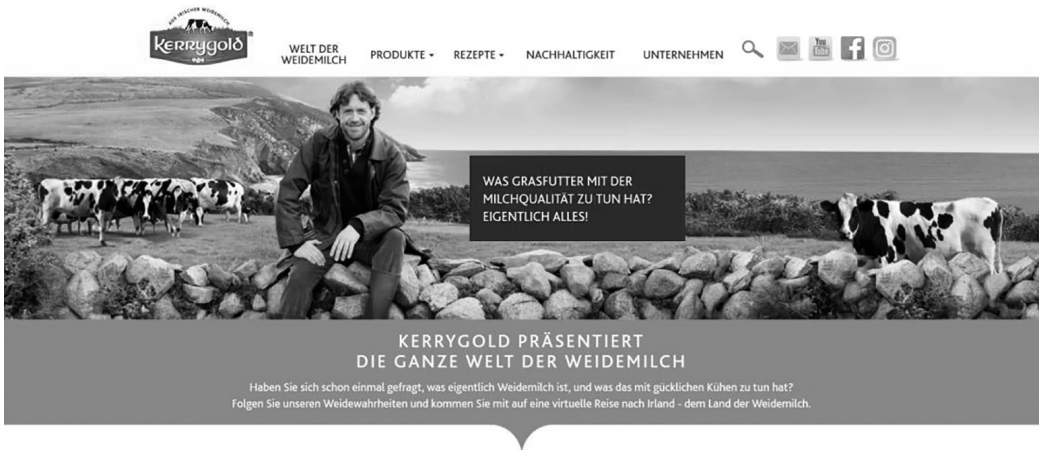

Figure 9.3. Detail of Kerrygold website first page

As viewers scroll down the page, they encounter an integrated video and a series of 'Weide-wahrheit' on Kerrygold. That is what is presented in the 'Welt der Weidemilch' section of the website (see Figure 9.4). There starts the strategy of product differentiation. Weidemilch is a neologism in German, meaning pasture, cows grazing outdoors. The website goes on listing a series of 'warheit' or true statements insisting on the specificities of Irish milk, and consequently on the quality of Kerrygold Irish butter.

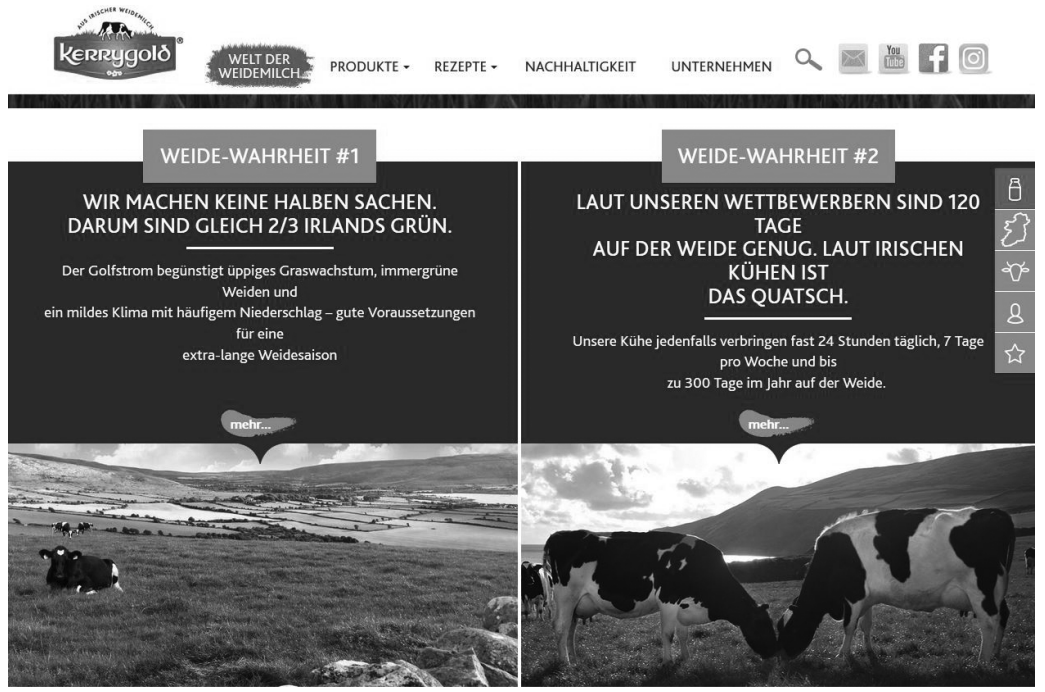

Figure 9.4. Details of Kerrygold myths 
Humour is manifest many a time to insist on the specificities of the product with sentences such as '[our] competitors state that $\mathrm{I} 2 \mathrm{O}$ days outside is enough; cows in Ireland say it is wrong, and they stay up to 300 days ${ }^{60}$ As with touristic brochures, marketers for Kerrygold reinterpret the myth of the changing weather, ${ }^{61}$ reinforcing Ireland's green image and the quality of the product since cows are fed on that same grass, an even greener grass, turning the weather into an essential ingredient of butter making. A commercial on the website was praising rain in the rainy day campaign, ${ }^{62}$ explaining to German customers why Ireland's meadows were always green: the Green Erin.

Such arguments do appeal to German consumers concerned with environmental issues, as one page draws a parallel between an empty stable (thus stressing the fact that cows live outside) and the well-being of cows, in comparison with huge farms in Germany, which are often no longer family concerns. Questions such as 'Warum sind Kerrygood Kühe glücklicher?'63 are addressed to viewers. The answer provided on the website emphasizes that cows stay outdoors, because they have more room to roam and are less numerous. It goes hand-in-hand with the strong insistence on small herds and family farms in Ireland, ${ }^{64}$ again

60 German sentence. <https://www.kerrygold.de/welt-der-weidemilch.html>. [Accessed 3I October 2017].

6I Cf. Jean-Pierre Marchand, 'Tourisme et contraintes climatiques: l'exemple irlandais', Bulletin de l'Association de Géographes Français, 63, 5, 1986, 369-74. See also Richard Deutsch, 'La publicité de l'Office du Tourisme Irlandais en France', Études irlandaises, Irlande-Images. Actes du colloque de la SOFEIR, Dijon I994, I33-43.

62 'Kerrygold goes back to roots for rainy day campaign', The Irish Times, 27 June 2013. The article states: 'For its new online campaign targeting the export market, Kerrygold has gone back to its roots - literally. It's all about Irish grass and the first of four short films called Celebrating Rain explains that the butter is made from the milk of grazing cattle. 'The rain', the script goes 'triggers a sort of alchemy as green turns to gold' blarney maybe, but it helps tell a convincing story'.

63 English translation, 'Why are [cows] happier?'

64 A TV campaign was launched to coincide with the fortieth anniversary of the Kerrygold brand in Germany, entitled 'The Meadow Milk'. It was organized around a series of integrated videos on the website, one of them being $A$ Day in the Life, 
in stark contrast with images of huge German farms in people's minds where cows stay indoors most of the time. However, what the website or commercials fail to mention is that Kerrygold butter is very much an industrial product, and it is exported in huge blocks to Germany where it is repacked in a production facility, before being retailed in a German supermarket or exported to other European countries. ${ }^{65}$ In other words, clever marketing campaigns manage to show that Irish butter is traditional, made on small farms in Ireland, in other words a sustainable process, insisting on the key images German people are attracted to. The Irish Dairy Board is keenly aware of that, as the Irish Farmers Monthly was stressing since 'advertising campaigns for Kerrygold butter have highlighted the natural lifestyle of dairy cows fed outdoors on rich grasslands' (see Figure 9.5). ${ }^{66}$

stressing a life on the land, cows grazing all day and all year long. It also presents farm activity as a family business (which is the case with the majority of farms in Ireland, 99 per cent according to the video) where cows are presented as pets, grass as natural, and where the whole family is engaged in the business. When they met at the table, as an Irish traditional family tends to do, they drink milk and eat cheese from the farm. See also Doyle, 'Kerrygold marks 4oth anniversary in Germany via social-media push - Life | siliconrepublic.com - Ireland's Technology News Service'. See also Joe Dermody, 'Kerrygold sales in Germany to exceed $€ 280 \mathrm{~m}$ by end of year', Irish Examiner, 5 September 2013.

65 D. Scally has described the manufacturing process of Kerrygold butter in a 2012 newspaper article in those terms: 'On the factory floor, eight people per shift keep an eye on the huge steel machines that work day and night, tearing apart and repacking the frozen butter packs that arrive from Ireland. Blue conveyor belts transport the butter products to pallets in the next hall which are shrink wrapped and ready for transport to stores as far as Poland, Austria and the Czech Republic'. D. Scally, 'Food firms keen to serve up in Germany', The Irish Times, 7 April 2012.

Irish Farmers Monthly, 'Kerrygold - still growing in Germany', July 201 46. 


\section{WEIDE-WAHRHEIT \#3}

AUF DER ANDEREN SEITE IST DAS GRAS IMMER GRÜNER. WILLKOMMEN AUF DER ANDEREN SEITE.

nate

Kerreggold

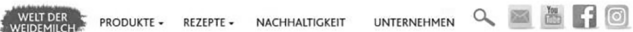

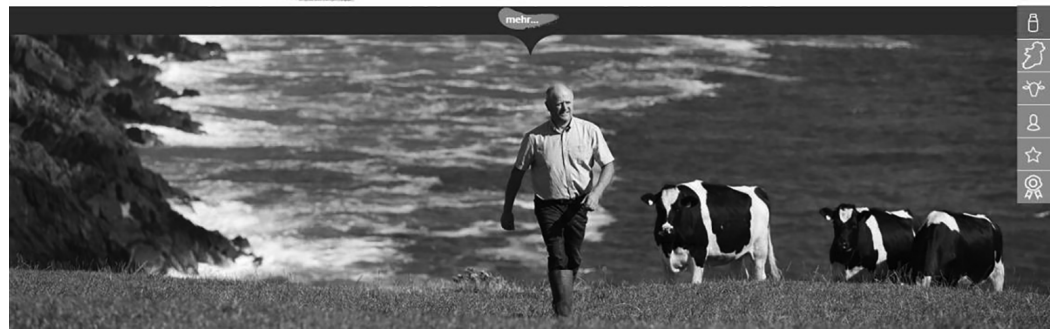

Figure 9.5. The grass is greener on the other side - welcome to Ireland

As one can see, the sales pitch used by Kerrygold marketers presents Ireland as a touristic destination and uses its landscape to promote its products. In that sense, the 2017 version of the Kerrygold website in Germany is not much different to what Patricia Lysaght had already remarked in the early 2000 s, since the marketing technique was also an invitation to travel to Ireland, linking the product to the country and to tourism. ${ }^{67}$ However, no one knows which specific part of the island of Ireland is mentioned. It is rather more some kind of mythical Ireland. A map found on the website explains that 80 per cent of Ireland is devoted to pasture. But once again, the difference between North and South is blurred: the image of the green island is what matters, the rest is not essential.

\section{Conclusion}

Kerrygold marketers have managed to shape conceptions of Ireland for their customers, presenting a country's identity in a manner that conforms to the image people abroad have of the country. As in a touristic

67 P. Lysaght, 'Taste Kerrygold, experience Ireland', 8I. 
brochure, the Irish landscape acts as a background on which the marketing speech for Kerrygold butter and other Irish dairy products sold in Germany reveals itself. In some ways, the landscape, the rainy weather, the soil, the sea and the Gulf Stream are all elements of an exceptional Irish terroir used to promote Irish butter in Germany. Both commercials and the website also promote the country itself, offering a form of 'tourism without travel' already referred to, and the process appears to be beneficial for both the Irish Dairy Board and the tourist board of Ireland. 'It is true', said Gisbert Kügler, former Managing Director of the Irish Dairy Board in Germany, 'that we have influenced the German view of Ireland and have probably made quite a big contribution to Irish tourism in the process. Even though many Germans have never been in Ireland, they have seen it on a Kerrygold advertisement and this has become their image of the country'. ${ }^{68}$

Kerrygold butter is used in Germany as a tool to promote a particular and clichéd version which offers a distorted image of Irish identity and culture, changing it into a mythical green island and an 'unspoilt garden ${ }^{369}$ in Europe. There is an ongoing stress on those same ideas which have received a hammering in the past few decades through various marketing campaigns in Germany. Reacting to the August 2012 poll results previously mentioned, Patrick McDonagh, former manager of IDB Germany in the early 1990s, was not that much surprised:

what should not be surprising is that in per cent of those surveyed would make an instant connection between Ireland and the Kerrygold brand. Bord Bainne, or the Irish Dairy Board as it is now known, directed much effort and considerable investment over a period of 30 years towards developing a credible connection between Ireland's clean, green and beautiful pastures and its dairy products - 'Das Gold der Grünen Insel, as the slogan had it. This was done mainly through the medium of German television with images of Ireland that almost invariably focused on the landscape. ${ }^{70}$

68 Quoted in O. Keogh, 'Buttering up the Germans', The Irish Times, 26 November 2012.

69 C. Murphy, 'Extra Marks to Kerrygold', Irish Independent, i7 May 201 I.

70 'Letters to the editor', The Irish Times, 29 August 2012. 
Over the last ten years, the Irish Dairy Board in Germany has tried to extend its market share by developing new products for younger customers. John Jordan, Marketing Director at IDB has explained that:

butter is a mature product sector with an older profile customer. Because of this, the IDB has looked to address this issue. The profile of the Kerrygold butter consumer, in Germany, is an older person, in a smaller household. Kerrygold is uniquely associated with Ireland and consumers relate to the product being pure and natural with the Irish association evoking a sense of warmth and heritage. It has a lot of warmth around it, it's Irish, natural and a lovely heritage to it. But for younger consumers we needed something different - their needs are different. We wanted to bring the heritage and give them a product that meets their needs. ${ }^{71}$

Using brand leverage, the Irish Dairy Board launched new products on the German market such as Kerrygold yogurts and Kerrygold Extra, a tubbed product with butter and rape seed oil.

In a comment on the 2012 study previously mentioned, Irish Times columnist Stephen Collins stressed the problem: 'while only a small proportion of Germans have visited Ireland or plan to do so', he wrote, 'a majority of them have a strong image of the country which many Irish people would regard as old-fashioned'. ${ }^{72}$ One can still find some family values associated with Kerrygold, as well as young farmers selling their products on the website. In that respect, one could assume that it is part of the brand's marketing strategy to cater for old and younger customers in a changing German society. But, the remaining question is: will Kerrygold butter, a piece of Irish culinary heritage for German people, or the other Kerrygold products, continue to be marketed strategically along the same traditional lines, or will marketers bring into their campaigns images of a twenty-first-century Ireland? Though patrimoine usually connects people with the past, a complete dis-connection with the world that surrounds them should be avoided, particularly among new generations who are much more mobile and more informed than their elders were.

7I Quoted in Irish Farmers Monthly, 'The Story of Kerrygold', July 20I I, 28.

72 Stephen Collins, 'Rolling, rainy pastures and butter: How Germans see Ireland', The Irish Times, 27 August 2012. 
PART IV

Literature and Patrimoine 



\section{Io 'Enfants d'ici, parents d'ailleurs'}

“"Going to England" or "across the water", ' '[franchir] la Méditerranée' and

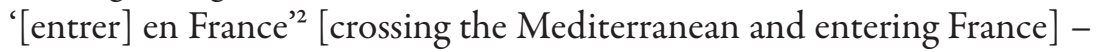
here are two experiences that would seem to be literally miles apart, and yet they share a number of features at a particular period in twentiethcentury history, the post-war era. Emigration from Ireland to England, or from Algeria to France, had started long before the war years but, from I 946 onwards, both Ireland and Algeria witnessed a massive migration from their shores to a country that either used to be, or was still, a colonial power with close historical links. Although Ireland had partially achieved self-government in the early 1920 s, the post-war economy had not lived up to expectations, and England was the nearest, almost natural destination for thousands of young people suffering destitution in rural areas. At the same period the colonial system in Algeria was going through a crisis that drove thousands of the poorest of the poor from country villages to the big towns and then on to France.

Both migration trends were facilitated by freedom of movement across the sea. Controls that had been put in place between England and Ireland during the war were discontinued in the early 1950s. Between 1945 and 1975, Algerians also travelled freely between their country and the new land. Moreover, in the aftermath of the Second World War, both migrations were actively promoted by France and England, two countries badly in need of rebuilding, and both resorted to foreign workers in very large

I Enda Delaney, The Irish in Post-War Britain (Oxford: Oxford University Press, 2007), 20. Future references will be denoted by the abbrevation $I P B$.

2 Jacques Simon (dir.), L'immigration algérienne en France des origines à l'indépendance (Paris: Editions Paris-Méditerranée, 2000), I8I, I84. Future references will be denoted by the abbreviation $I A F$. 
numbers, especially unskilled labourers, who were willing to engage in very heavy work, in factories or coalmines, or on building sites for housing schemes, dams, tunnels, bridges or power stations.

In those post-war years, it was not just the Irish navvies, always on the move, who were 'the men who built Britain'. ${ }^{3}$ Many single Irishmen went over to England, often marrying Irish women emigrants, and then settling in the new country, sometimes only a few years after coming to England $(I P B, 158)$. Similarly, throughout the 1950s, many single Algerian men who had come to France for work, started a new pattern of migration by arranging for their wives or families to come to France too $\left(I A F,{ }_{184}-5\right)$, instead of leaving them in Algeria, where they sent on what money they could and visited once or twice a year.

Crossing the water in those years, whether it be the Irish Sea or the Mediterranean, resulted therefore in similar situations on the emotional level. New or very young families settled in an adopted country, England or France, and then children came along, turning the prospect of an eventual return home into a very remote possibility. At the same time, the emigrants' children, generally born and raised in the new country, soon came to realize that they were caught between two cultures - one inherited from their parents and then that of their country of birth.

Whether British-born to Irish parents, or French-born to Algerian parents, these are the families that Carole Saturno, herself of Italian descent, calls 'Enfants d'ici, parents d'ailleurs' [children born here to parents from another country]. ${ }^{4}$ When writing about the Irish in Britain, Liam Harte speaks of 'confluence' and 'cultural hyphenation'. In both cases, the sense of belonging to a particular culture and the notion of roots can become

Ultan Cowley, The Men Who Built Britain - A History of the Irish Navvy (Dublin: Wolfhound, 2001).

4 Carole Saturno, Enfants d'ici, parents d'ailleurs: Histoire et mémoire de l'exode rural et de l'immigration (Paris: Gallimard, 2005). A revised edition came out in November 2017. Future references will be denoted by the abbreviation EIPA.

5 Liam Harte, The Literature of the Irish in Britain: Autobiography and Memoir, I725-200I (Basingstoke, UK: Macmillan, 2009), xxxiii. Future references will be denoted by the abbreviation $L I B$. 
quite ambivalent for children who tend to live in a present moment that their parents see as temporary.

For the first generation of post-war immigrants, the life they had to leave behind, with all its habits, customs and rituals, was still very much part of their present life. It was both very far across the sea and also very close, so close as to be woven into the fabric of their whole being, and it was this particular cultural heritage that they wished to pass on to their children. Carole Saturno speaks of 'tout un univers du passé' [a whole world belonging from their parents' past] $(E I P A, 108)$ and it is the world that a number of second-generation immigrants have experienced alongside their very real present, and have subsequently written about.

\section{Two Generations: The Spade and the Pen}

A close reading of autobiographical writings by four second-generation authors, two French and two British, will serve as a basis for a concrete presentation of some of the similarities and differences in their experience of hyphenation, and of the way in which their parents' cultural heritage resonates within them. There are many life stories available in book form, but I have selected Brian Keaney and John Lydon for the English-Irish perspective, and Ahmed Kalouaz and Azouz Begag for the Franco-Algerian link. All four were born in the 1950s - Keaney and Lydon in London, Begag ${ }^{6}$ in the French city of Lyon, while Kalouaz was brought to France, to a village near Grenoble, aged only a few months. Lydon has had a career as a singer/song-writer, while the other three are writers in their own right. They have all made a name for themselves, as have many others in similar situations, in spite of, and perhaps also because of, their extremely poor background.

6 Azouz Begag is an academic and a researcher. He was Minister for Equal Opportunities in Jacques Chirac's government, from June 2005 to April 2007. 
Their parents, whether from Algeria or Ireland, had poverty and destitution in common when they arrived in their new countries after the Second World War. Keaney's father arrived in London aged seventeen 'and he had nothing other than the clothes he stood up in'. 'My family background is very very poor, ${ }^{8}$ Lydon notes at the start of his autobiography. Begag mentions the years of extreme poverty endured by his father under colonial rule: '[Il] avait passé la moitié de sa vie désarmé dans la misère coloniale en Algérie'. ${ }^{9}$ Kalouaz's father also hailed from a poverty-ridden, famine-stricken Algerian village: 'dans ton village aux murs de terre, tu étais un miséreux'. ${ }^{10}$ In the early years following emigration, the second generation also suffered a number of hardships, particularly poor housing conditions. The Keaneys lived in a 'terraced house' $(D H A, 43)$ in east London. John Lydon observes that he was born 'in a tenement, workingclass slummy' $(R N O$, io). All the many Kalouaz children were cooped up in a poor, makeshift house with their parents: 'cet intérieur de fortune où nous vivions entassés, ${ }^{11}$ and the area called Chaâba in Begag's Le gone du Chaâba was a small shanty town, or bidonville, outside the city of Lyon, up until 1968 .

Yet the father in each of the four cases had work and was able to provide for the families. Apart from Keaney's father, who was 'a boiler operator in a power station' $(D H A$, I2), the men worked on building sites: Lydon's father as a crane driver and the two Algerians as bricklayers. All they had was their strength, and their endurance, summed up in a recurring image, that of their hands, which are mentioned in the title of one of Kalouaz's books, Avec tes mains [With your hands], and are inseparably linked to the references will be denoted by the abbreviation $D H A$.

8 John Lydon, Rotten, No Irish, No Blacks, No Dogs (New York: Picador, 1994), Io. Future references will be denoted by the abbreviation $R N O$.

9 Azouz Begag, Le marteau pique-coeur (Paris: Seuil, 2004), 22. Future references will be denoted by the abbreviation $M P C$. Ahmed Kalouaz, Avec tes mains (Rodez: Rouergue, 2009), 57-8. Future references will be denoted by the abbreviation $A T M$.

II Ahmed Kalouaz, Une étoile aux cheveux noirs (Rodez: Rouergue, 2011), I2. Future references will be denoted by the abbreviation $E C N$. 
men and their spades or shovels. As Lydon writes, 'the Irish laborers all had hands like shovels' (RNO, Io), and Begag often refers to his father's hands, with the skin hardened by cement, as 'ses mains cimentées. ${ }^{12}$

The two Algerians could neither read nor write, and the two Irishmen had little formal education, and so their hands were their means of expression, their way of giving shape to their dreams as exiles and their hopes for a better life. Kalouaz calls it 'ce langage des mains' [what their hands alone express] (ATM, 87), a form of communication that gave the second generation access to an unknown world, that of books, their myriad of words, and the endless possibilities of creating through writing. What the first generation created with their hands and spades was turned into words by the second generation, using a pen.

Liam Harte says of the early Irish migrants to Britain that they were often 'characterised as an unliterary people who cleaved more to the spade than the pen' ( $L I B$, xviii). This could apply to both the Irish and the Algerian post-war emigrants. With little or no schooling, they insisted on passing on to their children what they saw as the key to a different life, namely education. Keaney's father 'was determined to give [him] the benefit of the education he had never had' $(D H A, 2)$. For Kalouaz's father, knowing how to read was the key to happiness: 'que nous sachions lire devait nous ouvrir la porte du paradis' [it would give us access to paradise] (ATM, 48). In a number of instances, the first generation's spade made it possible for the second generation's pen to flourish. ${ }^{13}$ It gradually opened their children's eyes to a different world beyond the familiar home environment, made them reflect about the tensions inherent in their complex cultural heritage and feel spurred to write about them.

I2 Azouz Begag, Le gone du Chaâba (Paris: Seuil, 1986), I46. Future references will be denoted by the abbreviation $G C$.

I3 Maggie, a teacher friend in Co. Donegal, suggests that there is 'a nod to Seamus Heaney' here. Even though the poem 'Digging', from the collection Death of a Naturalist, has nothing to do with immigration, it conveys a similar contrast between generations, between the 'spade' of the turf digger and the potato digger on the one hand, and the poet's 'squat pen' on the other. He goes on: 'But I've no spade to follow men like them'. In Seamus Heaney, Death of a Naturalist (Faber: London, 1966), I3-I4. 


\section{Language}

Through the autobiographical writings of all four 'enfants d'ici', the reader gets a glimpse of what was actually passed on and also what was lost, or became blurred, as the second generation grew up in a country originally seen as a temporary destination by their 'parents d'ailleurs'. In terms of these issues, language and religion will be considered first, followed by diverse cultural elements, including sensory perceptions, dreams and memories.

Language would appear to be one of the most natural forms of cultural heritage. Most emigrant families will tend to speak their mother tongue to their children, who will then also learn to speak the language used all around them, especially at school. The post-war Irish emigrants were the first generation who had been to primary school, with a curriculum designed by the new Free State $(I P B, 55)$, while the poor Algerian peasants only spoke Arabic when they arrived in France. Unlike Arabic, which was spoken daily at home by Algerian families in France and was, therefore, a living heritage for the second generation, Irish was already well on the way to being removed from everyday experience for the children born to Irish parents in Britain. For the first generation, the language of the old country had a lot to do with nostalgia and a sense of loss. Keaney and Lydon approach the loss in quite different ways, probably because the Keaneys had no Irish, whereas the Lydons were able to speak Irish, but had made a conscious decision never to speak it again once they had left Ireland.

Writing from a boy's perspective, Keaney turns into a joke something that must have been an emotional experience for his parents. '[My parents]', he observes, "listened to Irish radio ... My dad bought a special high-powered radio to pick it up ... It'd be on really loud ... The ridiculous thing was, my dad couldn't understand a word of Irish' ( $D H A, 95)$. Lydon, on the other hand, feels the loss keenly and yearns for a special heritage that was never passed on: 'it left me isolated and shallow inside. I wanted to go out of my way and find out about my own Irishness' $(R N O, 27)$.

Kalouaz and Begag soon became bilingual, in French and Arabic, like their brothers and sisters, but they never learned to read and write their parents' mother tongue. They often had to act as translators to help 
their parents, or to teach them useful French words, thus turning the rules that usually govern linguistic heritage upside down. As the children in the second generation grow up, go to school, and eventually leave home, Arabic becomes less and less relevant, as it is sidelined by the language of the country in which they were born and that they see as their own. As Begag writes, 'nous avons appris le français ... on est français' [we have learnt to speak French ... we are French] (MPC, 188). Kalouaz even writes that Arabic has become a foreign language that they stopped speaking a long time ago: 'une langue étrangère ... que nous n'utilisons plus depuis des lustres' $(A T M, 9 \mathrm{I})$. Unlike Lydon, Begag and Kalouaz do not seem to have missed out on a particular heritage. Theirs has been slowly eroded with time.

\title{
Religion
}

\begin{abstract}
Alongside language, religion, with its rituals, would also seem to be an essential element of the immigrants' cultural heritage, something to be passed on automatically to the second generation: the Catholic faith in the case of the Irish families in England, and Islam for the Algerians in France. Judging from the autobiographical writings under consideration, the rituals in either religion were duly passed on but the faith has been lost. Moreover, the reasons for the lapse sound similar. The post-war immigrants who came to England or France had left behind small rural communities, with their priests or preachers, and entered countries with relatively strong secular values $(I P B, 150 ; I A F, 213)$. There was, therefore, less pressure around them for a strict observance of the rituals of their faith. They may also have felt that keeping a low religious profile was a way of integrating better, and of becoming less visible or less different $(I P B, 167 ; I A F, 213) .{ }^{14}$
\end{abstract}

I4 Benjamin Stora et Linda Amiri, dir., Algériens en France, 1954-62: la guerre, l'exil, la vie (Paris: Autrement, 2012), 42. 
Both Lydon and Keaney were automatically sent to Catholic school, but they hated it. Keaney insists that it alienated him from the other children in the neighbourhood: 'it increased my feeling of separateness' $(D H A, 6)$. They both lost interest in their parents' religious heritage, just like Begag and Kalouaz. Begag does write about all the rituals involved in his circumcision, but would not hear of going to special classes to study the Koran ('école coranique', $G C_{217}$ ), afterwards, as his father suggested: 'Ah non, ... j'ai déjà assez de travail à l'école ...' [No way ... I've got enough homework to do as it is] $(G C, 218)$. As a boy, Kalouaz even decided to join his schoolmates for their 'catéchisme', or Catholic teaching, because it opened vistas into 'le monde des autres' (ATM, Iо०) or the world of his peers. Whether educated in a Catholic school or at the École de la République, the second generation would seem to have been granted a freedom of conscience that resulted, partly at least, from the first generation's displacement.

The gap between the two generations' religious convictions and practice becomes strikingly obvious when Kalouaz and Begag are supposed to take part in the rituals connected with their father's death and burial, where they are surrounded by preachers and relatives. They both feel out of place, observers rather than participants, in a ceremony that seems irrelevant, almost alien to them, as if religious practice existed on a very distant shore: 'combien nous étions loin de ces rivages' ( $M P C, \mathrm{I} 69)$, Begag writes. Deep inside, they belong to a completely different spiritual environment, devoid of prayers and mosques: 'Les mosquées ne faisaient pas partie de notre géographie' (MPC, 199), Begag writes.

Kalouaz goes even further, beside himself with anger at all the preachers that have completely taken over his private grief. Instead of joining the funeral ritual, he drives to his own 'géographie', or spiritual landscape, along a country road, through fields and woods, where he feels he can commune with the memory of his dead father: "je conduis ... sur une petite route de campagne. Un lieu qui t'aurait plu' [a place you would have liked] $(A T M, 94) .{ }^{15}$ For all four writers, religion has become an

I5 Kalouaz's reaction here is somewhat similar to Heaney's at his mother's death, in the sonnet sequence 'Clearances'. When the priest goes 'hammer and tongs at the prayers for the dying', he does not join in the responses or the crying but remembers 
empty shell, somehow reflecting a different experience to the spiritual environment of their parents in the old country.

\section{Food and Music}

Side by side with two pillars of cultural heritage embodied by language and religion, there are much more mundane, though no less important, elements passed on to the second generation. They are to do with little details in everyday life, tangible aspects of what it means to be raised by 'parents d'ailleurs' while all the time absorbing, almost breathing in the life around them, the here and now. Keaney and Lydon, the two London boys, hardly mention traditional Irish food. Only once does Lydon write about what he calls 'a treat with boiled cabbage and bacon ... done the Irish way' $\left(R N O, 1_{4}\right)$. Otherwise, Heinz canned food was on the table just about every day. North African food, on the contrary, is quite often referred to in Kalouaz's and Begag's autobiographical writings, particularly the semolina cakes eaten with honey: 'gâteaux de semoule et au miel' ( $G C$, I07) or 'gâteaux ruisselants de miel, d'huile et de sucre' [cakes with big dollops of honey, oil and sugar] $(E C N, 78)$.

They differ, however, in what the traditional food cooked by their mother means to them. To Begag, it is simply linked with the memories of his childhood in the shanty. In Kalouaz's writings, nostalgia is added to the smell of spices and honey - 'D'anciens parfums d'épices et de miel' $(E C N$, II5) - and to the taste of tea made with fresh mint leaves, a taste he says he has inherited, and a drink he enjoys making - 'un des mets dont j'ai hérité du goût et de l'envie de faire' (ECN, 24). Altogether, the picture of the four writers' culinary heritage is very contrasted, unlike their musical heritage.

the moments when they were together, peeling potatoes in the family kitchen, 'Never closer the whole rest of our lives'. In Seamus Heaney, The Haw Lantern (London: Faber, 1987), 27. 
Immigrants from Ireland or Algeria brought their own traditional music with them. Unlike the food, which was shared on a daily basis on the Algerian families' tables, the music from 'across the water' belonged to a completely different world. In none of the four authors does the reader find any common musical tastes between them and their parents. The generation gap, and the times they grew up in probably explain a lot. In the 1960 s and I970s, all four writers were very much involved in the pop scene: 'Top of the Pops' $(D H A, 95)$ or 'le hit parade' $(G C, \mathrm{I} 3, \mathrm{I} 47)$ for Keaney and Begag; 'Alice Cooper and Hawkwind ... T. Rex' (RNO, 58) for Lydon; guitars for Kalouaz (ATM, 62).

The traditional musical heritage from the parents' generation, whether Irish or North African, hardly held any appeal for the second generation. Listening to Irish music in post-war London, or to North African music in Lyon and Grenoble just did not go together. Keaney sounds very much like a teenager when he writes 'my parents liked all that scraping away on fiddles and screeching through tin whistles' $(D H A$, 95). Kalouaz and Begag remember their fathers listening to North African music on a small radio set, when they were teenagers. They were witnesses to a form of communion with the past in which they had no part. As Kalouaz notes, "les chansons que tu écoutais ne se partageaient pas' [the songs you would listen to could not be shared] $(A T M, 89)$, because they were 'la ... musique de l'exil' [songs of exile] (ATM, 62), inextricably linked with the immigrant's experience of leaving everything behind, an experience about which the second generation could only guess.

\section{A Creative Cultural Heritage}

With language and religion all but cast aside, and food and music more or less in the background, it would seem that very little cultural heritage was actually passed on by Algerian and Irish parents to their children in the post-war years. And yet the very fact that they have felt the urge to write about their life in a first-generation immigrant household, would tend to 
suggest that something was passed on after all, something that had less to do with a particular country than with an intensely human predicament, that of the desperately poor immigrants who had chosen to go into exile. What is striking about the four authors, particularly the two French ones, is the emotionally powerful imagery inherited from the living example of a man they lived with as children and teenagers.

Deep respect and admiration are felt for an ordinary man who achieved extraordinary things by choosing to go into exile and dedicating his whole life to the future of children who, nonetheless, became strangers in the new land 'across the water', and to the fulfilment of a dream of return to the homeland that rarely materialized. Keaney writes about his father, who did not care at all what people thought about him and the way he looked, and just carried on with what he wanted to do: 'Looking back on it now, I admire him' $(D H A$, I2). For Lydon, his father 'had a much harder life than most people I know' and he 'did the best he could' $(R N O, 23)$. Kalouaz devotes a whole book to his father - Avec tes mains is a tribute to a simple man whom Begag would call a hero: 'cet homme que j'avais tant admiré' [the man I had admired so much] ( $M P C$, roo). Powerful images of the emigrant's dignified stance have been passed on to them.

Through the writings of Kalouaz and Begag in particular, these men and their choice of exile acquire epic proportions. What the second-generation authors write about them is not just a life story, it is an adventure story, a voyage of discovery into the unknown. Kalouaz calls them pioneers, 'éclaireurs' $(A T M, 32)$, the very word used by Salim Jay in an anthology ${ }^{16}$ dedicated to writings of emigration/immigration in the Mediterranean basin. Begag compares his father to Christopher Columbus or Vasco de Gama: 'Il avait découvert le nouveau monde' [he had discovered the New World] $(M P C, \mathrm{I} 26)$. Even if the New World was that of factories, building sites or power stations, the heroic missions the four writers' fathers carried (Casablanca: La Croisée des chemins, 20II; Paris: Atlantica, Séguier, 20II). 'Quelle belle brassée d'éclaireurs en quelque soixante torches!' [about sixty passages, like so many torches borne by a superb procession of pioneers], II. 
out right through to the end have been a fruitful source of inspiration, and so has their dream.

Lydon is the only one who never mentions the emigrant's dream of a later return home, and he even writes that his parents 'could never live in Ireland' $(R N O, 28)$. The dream is well and truly there, however, for the other three writers, who see it as an almost magnetic force that carried the men along from day to day and sustained them: 'my dad swore that he was going to get the money to build a new house on that land [in Ireland]', Keaney writes, 'That was his dream' $(D H A$, 97). For Begag and Kalouaz, the dream takes on a mythic dimension. 'il y aura forcément un jour un vrai retour, triomphal et définitif' (ATM, 44), Kalouaz writes about his father's unshakeable belief in a triumphant, final return home to a house of his own. 'Tant de fois il l'avait vue en rêve ... Tant de fois, tant de rêves, pour ça' [He'd dreamt of it so many times ... So many times, so many dreams, for just that] $(M P C, \mathrm{I} 23)$, Begag muses over the house in Algeria his father dreamt of taking his family back to, and where he will never live, because he has just passed away.

All four writers insist that they fully belong to their new country, the place where they grew up. When Keaney's mother tells him that he'll 'be able to come home' to the new house that his father is going to build in Ireland, he thinks: 'Home ... Home for me was England' ( $D H A$, ı००), echoing Kalouaz's 'chez nous' $(E C N, \mathrm{I} 6)$, when he speaks of his home village near Grenoble. Near the end of his autobiography, Lydon muses: 'I was raised in England, and I am English in this way. Romantically, I would like to believe I'm Irish ... I know this isn't real ... I am British' ( $R N O, 320)$.

'J'étais devenu Franc, Gaulois' [I'd become a Frank, a Gaul] $(M P C$, II ), Begag writes, and he regularly alludes to his French identity. Kalouaz calls France 'un pays réel' [a real country], as opposed to the old country venerated, even idealized by his father, 'le pays idéalisé' $(A T M, 44)$. The sheer strength of the dream does become tangible, however, in the building of an actual house, in Ireland by Keaney's father, and in Algeria by Begag's and Kalouaz's fathers. However, the father's dream come true, a real house in the old country, is closer to a picture postcard than to a real home: 'paysages de cartes postales' (ATM, 59), as Kalouaz writes, and yet the dream has been passed on to their sons who have turned it into works of art. 
The pens held between the fingers of the 'enfants d'ici' have definitely taken over from the spades in their fathers' hands. The second-generation writings reflect the way these authors approach their cultural heritage. To their parents, the heritage brought from the old country was something to hold onto because it defined their very being. It was always there, in the background. To the second generation, it is a background presence too but its importance has been displaced. From a life-sustaining force in their parents' daily life, the heritage of immigration has become a life-giving force, through a strong creative impulse. Over two generations, distance has turned heritage as memory into heritage as imagination.

Judging by the six books used as a basis for research into the cultural heritage of emigrants from Ireland and Algeria in the post-war years, it appears that very few tangible elements have been passed on to the second generation. Language and religion have been relegated to a distant background, and the four authors have retained only memories of a childhood and teenage years spent in a home environment different from that of their peers. And yet, it is precisely in the perception of various differences that their new life has been enriched, to the point where some of them have felt the urge to put pen to paper and to couch in words what it meant to grow up in an immigrant household. The four authors selected for the purpose of this paper all show some form of fascination for the written word, something that seems to have gripped them quite early on.

The French writers appear to be even more deeply attracted to the written word than the British ones. I would suggest that this is because two languages, French and Arabic, were experienced side by side from a very early age, whereas English was the main language spoken in Irish emigrant families, in spite of various efforts in Ireland to revive the Irish language over several decades. For Begag and Kalouaz, the French language became the pathway to learning and then writing, and it is precisely through this medium, which separated them from their parents, that they have been able to express what was actually passed on to them, when all else has been turned into distant memories. Images are their heritage, first and foremost that of the indomitable figure of the poor, proud emigrant with a passionate dream. A particularly moving acknowledgement is made by Begag, shortly after the death of his father: 'Quels livres allais-je pouvoir 
écrire maintenant?' [Where could I find inspiration for my next books?] $(M P C, \mathrm{I} 32)$.

This piece is dedicated to the men who came to France from Algeria and rebuilt the country where I was growing up, after the Second World War. My thanks go to Eamon Maher for suggesting the links between Algerian and Irish post-war emigrants; to Aisling Ní Dhonnchadha for recommending Liam Harte's research on Irish emigrant autobiography; to the staff at the Centre culturel irlandais in Paris, the Linen Hall Library and the National Library of Ireland for their invaluable help; to Carole Saturno for her support, and for letting me borrow the beautiful title of her book ; to my friend Mary for her patient, tireless help; and to Ahmed Kalouaz for his beautiful writing and his kindness.

Je soubaite dédier ces pages aux hommes venus d'Algérie après la guerre de 1939-45, qui ont reconstruit le pays ou je grandissais, et remercier Abmed Kalouaz pour ses belles pages et sa bienveillance. 


\section{George Moore: A Case of Dúchas/Patrimoine in Flux?}

This paper posits that, from the viewpoint of George Moore (I852-I933), national heritage is an ever-evolving store of riches. His interests in, and attitudes towards, dúchas/patrimoine can certainly be discerned in many of his writings. Moore's texts portray dúchas as intrinsically multifaceted, and as embracing time and place, arts and architecture, music, religion and folklore. In addition, his literary works intimate that aspects of received wisdom concerning such heritage are less 'set in stone' than they are reflective of ongoing and ineluctable sociological and political constraints, and of manipulation. When dúchas or patrimoine is labelled as an exercise in historical imagination, that description is far from exclusively negative or disparaging. Instead, and particularly relevant for the Moorian approach, the vibrancy and richness of creativity may enhance appreciation of a true cultural inheritance, partly by subjecting its features to literary scrutiny. Rather than any idea of imagination being inimical to authentic tradition, George Moore's diverse methods of depicting heritage in its various forms tend to endorse the nature and value of the subjective and artistic approach. Today, that attitude and pattern would receive widespread, approving intellectual assent even as actual practices continue to diverge. ${ }^{1}$

A noteworthy aspect of Moore's differing modes of engagement with manifestations of the concept of heritage or tradition is that they continue to appear in his writings over several decades. To illustrate both ubiquity and variety, this study will refer, amongst others, to literary examples from

I See Mary-Ann Constantine, 'Welsh Literary History and the Making of "The Myvyrian Archaiology of Wales"' in Dirk Van Hulle \& Joep Leersen (eds), Editing the Nation's Memory (Amsterdam: Rodopi, 2008), i25. Constantine says that since publication of The Invention of Tradition (1983), it has 'become commonplace to acknowledge the "creative" element in the shaping of cultural history'. 
An t-Ur-Gort (1902), The Untilled Field (1903), The Lake (1905), Hail and Farewell (1911-I4), The Brook Kerith (1916), Héloise and Abelard (1921), The Pastoral Loves of Daphnis and Chloe (1924) and Aphrodite in Aulis (1930). ${ }^{2}$ Even a quick inspection of Moore's literary output uncovers an ongoing interest in various aspects of what is considered to be dúchas. It can be said that although his attention to identity and cultural inheritance was in evidence throughout his long writing career (1870-1932), these particular texts, published within a time span of twenty-eight years, provide testimony to the centrality of duchas or patrimoine for Moore as man and as writer.

Undoubtedly, literature has the capacity to deliver and reflect duch as while, in itself, it may constitute a vital part of what is acknowledged as heritage whether in the sense of cultural, national, tribal, religious or racial identity. Literature is commonly viewed as part of the cultural riches of Ireland; there is even a presumption that literary ability is something more likely to be found in Ireland than in some other places. There are some solid grounds for that belief, but it also has the whiff of propaganda about its promulgation. Such a combination of reality and promotional effort is telling: it conveys how vital and close are the links of duchas with national image; simultaneously, it signals how important is the felt need to convince and persuade all citizens. It is interesting to find that George Moore evinced awareness both of material and of the need for publicity. When he returned to Ireland in 1901 , he was anxious to be part of building up the arts and thus the artistic riches of an Ireland that was moving towards nationhood and independence. As a concomitant part of that drive, he wished to stimulate young writers and he saw the Irish language as important.

2 An $t$-Úr-Gort (Dublin: Sealy, Bryers, Walker, 1902); The Untilled Field (London: T.Fisher Unwin, 1903); The Lake (London: William Heinemann, 1905); Hail and Farewell (originally published in three vols, Ave I911; Salve 1912; Vale 1914. Hail and Farewell has been more recently published with the three sections available in one vol.: Richard Allen Cave ed., Hail and Farewell (Gerrards Cross, Bucks: Colin Smythe, 1985); The Brook Kerith: A Syrian Story (Edinburgh: T. Werner Laurie, 1916); Hélö̈se and Abelard (London: Cumann Sean-eolais na h-Éireann, 1921); The Pastoral Loves of Daphnis and Chloe (London: William Heinemann, 1924); Aphrodite in Aulis (London; New York: William Heinemann; Fountain Press, 1930). 
One of his first literary contributions to possible future heritage was to publish $A n t U^{\prime}$-Ghort, a collection of his short stories for which he commissioned an Irish translation. ${ }^{3}$ On the cover of $A n t U^{\prime}$-Ghort, his name duly appeared as Seorsa O Mordha. ${ }^{4}$ Although Moore did not speak Irish, he was keen to foster widespread use of the language and as instance of his determination, the stories were first published in Irish: their Englishlanguage versions in The Untilled Field did not appear until the following year. Since Moore's contemporary view was that a nation should have a literature that would grow and develop, it is clear he believed that the national literary treasure house could never be considered as complete but would be continually augmented over the ages.

The nature of Moore's short stories in The Untilled Field was remarkable: they were unconventional for the period and very noticeably nonVictorian in their style. In furnishing such a model for new young Irish writers, Moore's aim was to lay down 'dúchas' for the future. His approach differed markedly from that of people like Samuel Ferguson and Thomas Davis whose chosen literary forms owed more to established and prevailing conventional literary taste even while their sentiment was strongly and obviously nationalistic and designed to generate and foster a national spirit. Moore shared those underlying nationalistic motivations, but the style was new and his literary offerings were flavoured more by French authors and by Turgenev. The unspoken inference was that 'foreign' influence could be incorporated into Irish patrimoine, and that such cross-fertilization would be enriching. In fact, it would seem that Moore judged that still-existing constituent parts of 'true' Irish heritage were in need of rediscovery and rebirth; and more seriously, that the absence of renewal would result in

3 The principal translator was Pádraig Ó Súilleabháin (Patrick O’Sullivan) who translated five stories. Tadhg Ó Donnchadh translated one story, 'An Gúna Pósta'. Much information concerning the translation and re-translation processes is provided by Padraigín Riggs in 'An t-Úr-Ghort and The Untilled Field', in Mary Pierse (ed.), George Moore: Artistic Visions and Literary Worlds (Newcastle: Cambridge Scholars Press, 2006), 130-4I.

4 The root of Moore's language enthusiasm and the range of his plans for its implementation make for entertaining reading. See Adrian Frazier George Moore 1852-1933 (New Haven, CT; London: Yale University Press, 2002), 288, 289, 292, 303. 
the crumbling away of any surviving remnants of genuine heritage. To uncover truth to and for the Irish, and to strengthen the core traditions, some myths would need to be faced and discredited: to that end, the stories of The Untilled Field featured diverse clergy, strong women, governmental folly, the powerful draw of home place, petty snobberies, ill-fitting made marriages, charity and hypocrisy. The certainties concerning rectitude, 'established' attitude and practice were probed; the idea of immutable heritage was definitely undermined. In the short term, the light shone on rural society may have been more successful in prolonging defensive blindness than in illuminating a forward path. In the longer term, societal denials would persist while the eventual literary legacy would be stimulating and productive, and dúchas could be debated.

In Hail and Farewell a decade later, Moore recorded his opinions regarding language and literature, those interrelated constituents of national culture, as well as on the undisputed existence of a third pillar of the presumed national heritage, religious belief. In discussion with AE, Moore claims: 'I came to give back to Ireland her language'. AE's view is that 'Ireland stands in need of a new religion'. Moore is adamant: 'And a new language. One is no good without the other'. He adds: 'The filing of theological fetters will be a task for the next generation'. AE sounds pessimistic: 'Ireland will not be an Irish-speaking country for the next fifty or sixty years and a hundred years will have to pass before literature will begin in Ireland'. It is Moore who maintains that it would be necessary to revive the Irish language ${ }^{5}$ while $\mathrm{AE}$ avers that 'the Anglo-Irish idiom would be sufficient for literature'. Despite that disagreement, both men obviously believed that heritage would continuously evolve, albeit at an unsatisfactorily slow pace. ${ }^{6}$ Moore's cautious optimism was ultimately dashed, and he admitted his disillusion to Kuno Meyer: 'It seemed to me that a new language was

5 In this, Moore was far from alone. 'Culture ... from the Romantic period onward has been insistently linked to the idea of a shared language, and considered as expressing itself most authentically in the oral and written literature in that language'. See Joep Leerssen 'Philology and the European Construction of National Literatures', Editing the Nation's Memory, 13-27.

6 See exchanges in 'Salve', in Richard Allen Cave (ed.), Hail and Farewell, 279; 343-4. 
required to enwomb a new literature. I am done for. Ireland will not forgo her superstitions for the sake of literature."

Aspects of Moore's own inclinations regarding heritage emerge in facets of patrimoine displayed in his novella The Lake (1905). As he foregrounds the glories of Irish landscape and allows musing on a golden monastic age ${ }^{8}$ in the country, he seems to intimate that a true Irish spirit or character is an important part of tradition, that to uncover such a spirit will require a jettisoning of contemporary preaching and mores, and that thereby there could be a return to more inspired former times, to a purer version of duchas. ${ }^{9}$ Retrieving that spirit may also need a reawakening to nature. This reflection on the characteristics of national inheritance recognizes its mutations over centuries, the potential for instability, the possibility of dilution or contamination, and the need for reassessment. In one such example, Father Oliver Gogarty, the central character in the story, engages with the dilemma of whether there should be restoration of an old abbey that dated from 'the seventh and eighth centuries, when the arts were fostered in monasteries'. Gogarty has doubts 'regarding the right of the present to lay hands on these great wrecks of Ireland's past'. He asks, 'Which is the better - a great memory or some trifling comfort?'. The 'trifling' comfort referred to was a new roof on the abbey to shelter congregations from rain, cold and wind $!^{10}$ The argument mirrors

7 'Salve', 383.

8 As Father Gogarty muses: 'Religion in Ireland in the seventh and eight centuries was clearly a homely thing, full of tender joy and hope, and the inspiration not only of poems, but of many churches and much ornament of all kinds, illuminated missals, carven porches' (The Lake, 96-7). Gogarty refers to the period as 'Ireland's halcyon days' when 'a deep peace brooded, and under the guidance of the monks Ireland was the centre of learning.' Providing the contrast of past 'halcyon days', and 'tender joy and hope' with the harsh inflexibility of prevailing ecclesiastical rule gave some licence to dissent in favour of traditional belief and practice.

9 It is noteworthy that a similar sentiment is expressed by French composer André Jolivet (1889-1974): 'I was seeking to restore to music its original ancient sense, at a time when it was the magical and incantatory expression of the religiosity of human societies. Contrepoints I (January 1946), 33. 
a quandary frequently encountered in all ages - related questions arose at Newgrange, amongst other places - namely, do the icons of dúchas remain forever untouched, unchanging, maybe even be allowed to fall down? Or should they be reconstructed with the attendant risks of misconstrual or falsification?

Reconstruction can be extremely controversial. The arguments over the authenticity of the presentation of Newgrange relate to diverging archaeological theories. Discord concerning revisionist presentations of national history, or disagreements over newly imposed country borders, have ultimately even more fatal human consequences. A tragic illustrative instance is that of Iraq - a country that many in the western world perceived as an ancient civilization. In more recent years, it was ruled by a brutal dictatorship, was then invaded in dubious circumstances and reduced to rubble in resulting conflicts. However, scholars point out that the notion of Iraq as a nation or state is a colonial construction that is not yet a century old rather than having existed for millennia. ${ }^{11}$ The fiction of an ancient Iraq became a widely believed account, despite the historical reality. The 'ancient history' image of ninety-six-year-old Iraq underscores at least two elements pertinent to consideration of a heritage narrative: its potential for forgery and its often-contested nature. Those factors would support the belief that patrimoine is prone to change, mutation and to misrepresentation while the complex situation in the territory also foregrounds resolute Kurdish resistance to any denial of their own national identity. On all sides, heritage is a battleground.

The name 'Iraq' was only chosen in I92I. The territory of ancient Mesopotamia, taken by Britain during the First World War, remained a British mandate country until 1932. British troops again invaded Iraq during the Second World War to prevent the territory from joining the Axis powers. Parts of the lands bordering Turkey and Syria moved from one jurisdiction to another - Kurdistan which had existed as an entity from classical times, and through the Middle Ages and afterwards under Ottoman rule, was arbitrarily broken up and parts of it assigned to Armenia, to Iraq (British mandate) and to Syria (French mandate). Kurdistan, apparently vanished as geopolitical and economic forces ensured its fate, 'disappearing' it into a country now to be called Iraq. In the interests of some international and local power groups, the aim was to submerge distinct Kurdish nationality with its separate language and religions. 
After his 'Irish' short stories, aspects of national identity and patrimoine would continue to interest Moore. His focus extended beyond Irish shores and the frequency with which his texts are suffused with cultural features of other realms is notable. He recognizes and explores elements that are, arguably, considered as essential components of heritage. At the level of title and story, this is apparent in his approach to Greek culture. Remarkably, and successfully, he treats both subject and form of the classical Greek novel in Daphnis and Chloe (1924). At a very minimum, this is acknowledgement of what is widely accepted as Hellenic dúchas; that said, Moore's is more than a superficial appreciation because his expert and painstaking remodelling of the core elements of the classical Greek novel evidence his understanding of, and deep esteem for, the essentials of that literature. His determination is to distinguish its structure and defining qualities, thereby to delve into the heart of Greek culture. ${ }^{12}$ It was not his only engagement with Greek stories for he later chose Greek legend in his book Aphrodite in Aulis (1930). That fictional tale recounts the building of a temple in Aulis, a monument that is designed to be part of Greek heritage for later generations. The central characters possess abilities that contribute positively to heritage - Thrassilos is an architect; Rhesos is a sculptor - and the achievement of the temple with its statue of Aphrodite is marked by the visit of Sophocles, Phidias, Euripides and Aristophanes. In gliding into Euripidean territory, Moore lets Aulis conjure up the memory of Agamemnon and the Trojan war, of the Parthenon and Greek drama - he dares to engage with the foundation legends of western civilization while situating the events within a family circle. Moreover, Moore portrays a dúchas to which additional elements are added over years.

Moore's deep connections to France, French literature and art began in the 1870 . Somewhat surprisingly, it is a mediaeval French love story that attracts him some fifty years later. In Moore's version of the tale of Héloïse and Abélard (1921), he engages with history and myth that rank highly in

I2 For an expert evaluation of Moore's engagement with classical Greek, see Konstantin Doulamis, 'Lost in translation? George Moore's The Pastoral Loves of Daphnis and Chloe and rewriting Longus' in Mary Pierse (ed.), George Moore: Artistic Visions and Literary Worlds, 86-ıог. 
the heritage of France. As philosophers choose to focus on the theological differences between Abélard and Bérnard of Clairvaux, it is the presumed romantic links between Héloïse and Abélard which have become part of French myth and legend and contributed towards making their memorial one of the most visited in Père Lachaise cemetery. That popular belief makes the story of Héloïse and Abélard a strong and vivid part of French patrimoine. Arguably, it is the arguments and counter theories concerning the authenticity of their letters, the identity of their enemies, and the fate of their son, which copperfasten their position in the public mind rather than contributing to its dismissal. Each member of the public may interpret the story differently, but each evinces a commitment to its national heritage centrality. Thus, the binding force of a 'national' belief simultaneously embodies contradictions and the elements of its possible disintegration.

It can be posited that Moore's venture into the heritage of Greece and France is but the logical extension of his explorations of Irish myth and legend, his study of Irish storytelling and his ongoing interest in dissecting the minutiae of such heritage. ${ }^{13}$ An aspect with particular interest for him was reception of the religious canon, and while he had focused on the contemporary in The Untilled Field and The Lake, ${ }^{14}$ his most controversial engagement with religious patrimoine was when he turned back two millennia to the Bible. Moore foregrounds key scriptural tenets in The Brook Kerith (1915), his 'biblical' novel, in which Jesus does not die on the cross but is saved by Joseph of Arimathea and lives on in seclusion as a shepherd at the Brook Kerith. ${ }^{15}$ In composing this story, Moore may be seen to interrogate the validity and authenticity and the rationale of any 'duchas' canon, gently suggesting that what is handed down as an essential part of culture and belief may well be open to scrutiny, reassessment,

This is particularly in evidence in A Story-Teller's Holiday (1918) but also in The Brook Kerith (1916).

I4 In his so-called musical novel, Evelyn Innes (1898), and in its sequel Sister Teresa (I90I), Moore had visited many religious-related issues ranging from clerical influence to morality, beliefs and convent life.

I5 The Brook Kerith is the place where, according to the Bible, Elijah had been sent for rest and where he was miraculously fed (Kings 17 ). 
revision - and furthermore, that certain interest groups will adhere doggedly to one interpretation or another. The outcome of such attitudes had been spelt out rather more directly by the character of Fr O'Grady in The Lake:

Millions have owed their deaths to tortures they have received because they differed regarding some trifling passage in Scripture. There can be no doubt of that, but it is equally true that Christianity has enabled many more millions to live as much from a practical point of view as from a spiritual. If Christianity had not been a necessity it would not have triumphed. ${ }^{16}$

While people may feel a deep need to be embedded in heritage, but still are frequently unwilling to query or critique its elements, let alone contemplate or acknowledge any evolution in its nature, the critic can expect certain disapproval and censure. There was ongoing condemnation of Moore's questioning and novel approaches. The messenger of change was to be resisted and attacked even when interrogation of the 'cast in stone' nature of duchas and patrimoine was amply justified. Undoubtedly, the possibilities of concocting or influencing perception of tradition were understood by those who 'manufactured' or manipulated culture for political or other reasons. Such interpretation and presentation of 'culture' would attract much attention in several countries in the nineteenth and early twentieth centuries. A case in point, and one with which Moore was certainly familiar, was the demonizing of Wagnerian music as anti-French propaganda from $1914 .{ }^{17}$

It is understandable that, in the case of small nations, it is important to construct a self-image to counterbalance any negative national characterization attributed by others. Part of doing that requires a purposeful promotion and identification of art and archaeology, literature and music, history and what might be called character. Inevitably, the assessment of relative importance of any and all of those is rather subjective and it will

The Lake, 80 .

I7 See Marion Schmid, 'A bas Wagner!: The French Press Campaign against Wagner during World War I' in Barbara L. Kelly (ed.), French Music, Culture and National Identity 1870-1939 (Rochester, NY: University of Rochester Press, 2008), 77-91. 
further depend very much on the context and on the period. The success of fostering acceptance of proposed ingredients of the culture will surely owe much to repetition, to the clear 'selling' of the story, regardless of whether it is closely aligned to truth or reality - or not. In the opinion of MaryAnn Constantine, 'their "authenticity" almost ceased to be relevant'. ${ }^{18}$ In that light, a glance must be cast on two Irish symbols: the round tower and the shamrock.

The Irish round tower and its origins and purpose were hotly debated in the nineteenth century and they remain the subject of some speculation. In mid-nineteenth-century Ireland, some embraced the idea of a Phoenician/Tuatha de Danaan origin for round towers and thus postulated a duch as with a long link back to ancient history; others saw another version of duchas wherein those same round towers dated from the eleventh century and were closely allied to monastic settlement. ${ }^{19}$ The same physical structures gave rise to different stories, different ideas of an Irish dúchas, one more secular, and the other with religious connections. ${ }^{20}$ Even outside any political agenda in invention and establishment of a certain cultural heritage, there are often other reasons for caution concerning the existence of any permanent or canonical dúchas or heritage package - time might tell a different story. For instance, carbon dating and modern technological examination may yet furnish support to one round tower theory or to none. Perhaps the noteworthy lesson is that both 'camps' in the round tower disputes were convinced of the great significance of duchas itself, of the importance of its visual imagery for themselves and for their idea of nation.

I8 Constantine (op. cit.) says 'cherished national myths often rest on trembling foundations' (125).

I9 Henry O'Brien (in The Round Towers of Ireland or the History of the Tuatha-deDanaans, 1834) argued for Buddhist and Atlantis links via the Tuatha de Danaan. George Petrie asserted they were associated with monastic settlements (The Ecclesiastical Architecture of Ireland: An Essay on the Origin and Uses of the Round Towers of Ireland, 1845). Petrie's design for the grave of Daniel O'Connell included a round tower.

20 Even the notorious Madame Blavatsky had an opinion: she held that the towers were pre-Druidic. Other theories include their possible magnetic influence as well as their existence as status symbols or phallic imagery. 
The shamrock provides another illustration of what is memorable in cultural imagery. Both within and without Ireland, that image is readily identified as Irish. The shamrock is an excellent example of a combination of image, history and myth, all bound up with the defining quality of a differentiating religious allegiance. So, for some people, the Irish shamrock invests the country with a history, a visual symbol, a Christian heritage that is sometimes - at a minimum, subliminally - linked to brave resistance against centuries of faith-and-fatherland persecution. For others, it is a piece of Irish jewellery, or a plant of uncertain botanical identity which gets worn on 17 March - or maybe gets drowned. Its symbolism varies from person to person but for most, it would be viewed as having become part of dúchas. Its initial success as an Irish symbol might owe something to the postulated connection to St Patrick and the Trinity, but in the wider world, the 'selling' of the shamrock and much other Irish imagery, like the harp and the wolfhound, is deeply indebted to Thomas Moore, both to his performances and to his lyrics, as well as to the artistic illustrations that decorated their publication. The combination of memorable verse, well-known tune and familiar imagery constituted powerful, reciprocal reinforcement of the cultural and nationalistic message.

Joep Leerssen identifies eighteenth-century philosopher Johann Herder (1744-1803) as the person responsible for the path of culture becoming 'the defining principle of nations' ${ }^{21}$ Leerssen pinpoints the nineteenth century as the heyday of national thought and he provides some salient examples of the mutability of the cultural icon and the national image over the course of a century after Herder. His examples are striking:

In the eighteenth century, Englishmen are depicted as suicide-prone splenetics; the next century sees them as unflappable, self-controlled phlegmatics with a 'stiff upper lip'. Germany for Madame de Staël is a country of tender individualism, metaphysical and musical sensibility, and romantic idyll; one century later, the imagery is dominated by Krupp engineers, scientists, and be-monocled Prussian officers. ${ }^{22}$

2I Joep Leerssen, 'The Rhetoric of National Character: A Programmatic Survey', Poetics Today, Vol. 21, no. 2 (Summer 2000), 267-93, 273. 
For Leerssen, this poses the intriguing question as to what governs such discursive shifts and volatility.

Any answer to Leerssen's query must include the need to define 'Ourselves' and 'Our' culture and du'chas in relation to 'Them' and 'Theirs'. This is the case at a given point in time, no matter who the 'We' and 'They' happen to be. In this decade, Fintan O'Toole outlined the general inclinations, but did he over-simplify the situation that he said had pertained in Ireland?

England was Protestant; so Catholicism had to be the essence of Irish identity. England was industrial; so Ireland had to make a virtue of its underdeveloped and deindustrialised economy. England was urban; so Ireland had to create an image of itself that was exclusively rustic. The English were scientific rationalists; so we had to be the mystical dreamers of dreams. They were Anglo-Saxons; we were Celts. They had a monarchy, so we had to have a republic. They developed a welfare state; so we relied on the tender mercies of charity. ${ }^{23}$

An explanation by the character of Fr Moran in Moore's The Lake (written over a century earlier) is not so different:

if Catholics were intolerant to every form of heresy, it was because they instinctively felt that the questioning of any dogma would mean some slight subsidence from the idea of nationality that held the people together. Like the ancient Jews, the Irish believed that the faith of their forefathers could bring them into their ultimate inheritance; this was why a proselytizer was hated so intensely. ${ }^{24}$

When oppressed people felt compelled to resort to the consolidating and fortifying images of cultural community, it was a natural reaction that served to mobilize their own public, but it was also frequently in response to government propaganda. While religious discourse featured prominently in the Irish situation, visual art was the hidden persuader in several other circumstances. Political use of landscape art was common in past centuries in America, France, Britain, Mexico and other places.

23 Fintan O'Toole, 'Brexit means Ireland must be the anti-England', The Irish Times, I8 April 2017.

24 The Lake, 47. 
In part, graphic imagery was employed to influence sectors with lower literacy levels. The Mexican use of roadside murals was eye-catching for all sections. The USA approach differed: the mid-nineteenth-century paintings and photographs of the American West - a significant number of which were the work of German Albert Bierstadt - set out to encourage migration to, and exploitation of, that area. ${ }^{25}$ The doctrine of 'Manifest Destiny' in America was to a considerable degree boosted by such pictures. ${ }^{26}$ In the last decades of the century, the French government sought to build a recognizable national identity by distributing landscape pictures to provincial museums. ${ }^{27}$

Early in the twentieth century and in the wake of revolution, Mexico encouraged artists to contribute towards a unified national identity that encompassed the legacy of Spanish conquistadores and the Aztecs. ${ }^{28}$ In Britain, Constable prints were first employed by government in the nineteenth century to create an iconic, if totally false, impression of a calm, rural country. In a war of images, they later provided a contrast to Gustave Doré's dark London scenes. By 1916, John Constable's The Hay Wain, was again disseminated, this time to exemplify 'England's Green and Pleasant

25 In addition to Albert Bierstadt (1830-1902), other notable artists in the genre were George Caleb Bingham (1811-79) and Frederick Remington (I86I-1909). The topic of propagandistic art has been covered extensively. An illustrative text is William H. Truettner, ed., The West as America: Reinterpreting Images of the Frontier, I820-1920 (Washington, DC; London: Smithsonian Institution Press, I99I), a text that accompanied the exhibition of that name. The outcry arising from that Smithsonian exhibition, and from the numerous subsequent controversies has been impassioned.

26 Use of landscape imagery in Britain and USA receives detailed treatment in Stephen Daniels, Fields of Vision (Oxford: Polity Press, 1993). The idea of 'Manifest Destiny' is also considered by Daniels, I80-99.

See Malcolm Andrews, Landscape and Western Art (Oxford: Oxford University Press, 1999).

28 The pre-eminent artist was Diego Rivera. He, with José Clemente Orozco and David Alfaro Siqueiros, were known as 'Los Tres Grandes', or 'The Big Three' and they specialized in murals. Amongst many other books covering the topic, see Shifra M. Goldman, Dimensions of the Americas: Art and Social Change in Latin American and the United States. Chicago: University of Chicago Press, 1994. 
Land' for which men should fight and die. ${ }^{29}$ Art historian Kenneth Clark extolled its patriotic uses in 1945 and the picture remains iconic and popular. ${ }^{30}$ Use of landscape pictures for political ends has not disappeared. A 200 I exhibition, 'Panoramas: the North American landscape in art', was carefully mounted to support the North American Free Trade Agreement (NAFTA) between USA, Canada and Mexico. It purported to show a unified continent with historical linkage between the three countries. ${ }^{31}$ In Ireland, there is also twenty-first-century visual projection of its own literary heritage in the form of posters and calendars depicting Irish poets, novelists and dramatists. Ironically, and unjustly, the portrait of George Moore is absent from all such visual material. Moreover, his literary works are markedly absent from tourist outlets in his native county. There is a price to be paid for dissent from accepted, conventional and established tradition.

What emerges strongly from George Moore's writings is that he is unwilling to see any common concept of dúchas as immutable. He campaigns inventively to alert his readers to the necessity for challenging dogmatism; he would encourage scepticism regarding the certainty of such presentations as the Panoramas exhibition. Moore admitted that attitudes can change - as his had done - and he encourages openness to amendment and revision. ${ }^{32} \mathrm{He}$ was also alert to the variety of methods that could influ-

29 See Daniels, op. cit., 25-9 and 200-42. The Hay Wain was not rated at the Royal Academy Exhibition of I82I although it was more successful in Paris when it was awarded a medal by Charles X in I 824 .

30 Kenneth Clark, John Constable, The Hay Wain (London: Lund Humphries, 1945), 8-II. A 2005 poll by BBC Radio 4 Today programme found that The Hay Wain was the second most popular painting in any British gallery. The ratings indicate a persistence of preferences that are influenced if not totally determined by governmental policy.

3I Persuaded by governments, material for the online exhibition came from Winnipeg Art Gallery; Canadian Museum of Civilization; Consejo Nacional para la Cultura y las Artes; Instito Nacional de Bellas Artes; Smithsonian American Art Museum. In Hail and Farewell, he admits that it had been his wont to despise the tenants who came to Moore Hall to pay rent because they could not speak English (294). Yet, on his return to Ireland at the beginning of the twentieth century, he became angry with people who had not learnt Irish. 
ence opinion - on a very practical level, the builder who repaired the roof on Moore's house in Ely Place had to advertise in An Claidheamh Soluis, as did the upholsterer and all the trades people with whom he dealt. This very concrete acknowledgement of the importance of finance is an element that is frequently absent from any discussion of dúchas, but it is an aspect to which Moore refers in several texts and in disparate ways. For instance, his snapshot of a small Irish town appears initially as geographical description, but it effectively presents a social and economic divide. ${ }^{33}$ Moore intimates that heritage may be, at least to some degree, dependent upon economic underpinning. That its existence and form could also be determined or influenced by climate is yet another prospect introduced by Moore: 'the Cinque Ports were deserted some centuries ago by the sea, their common benefactor, and now life moulders in Rye, Romney, and Sandwich amid recollections of better days. ${ }^{34}$ As time goes on, those recollections will inevitably mutate, and will contract or be expanded as the lens, focus and interests of recall demand.

With yet further demonstrations of transience, and in additional confirmation of his urge to highlight the ubiquity of uncertainty, ambiguity and insecurity in life and in heritage, Moore's fiction features cycles of alternating power and position. Such reversal of advantage receives unobtrusive treatment in Esther Waters where it relates to the Latch and Barfield families who have exchanged rank and social standing, with the former now in service to the latter. As the Barfield supremacy is recorded, Moore simultaneously, but quietly, provides evidence for its likely impermanence. His destabilizing of certainty concerning customs is not always so oblique: on occasion, it evinces tints of revolutionary intent. Sharp and scathing attack are numerous in A Drama in Muslin where the pomp and ceremony associated with the 'tradition' of presenting young girls at court

33 In the story 'The Exile' in The Untilled Field, there is clear division between the 'broken pavements and dirty cottages' and 'the slated roofs' and splendour of the convent further up the hill (The Untilled Field, Gloucester: Alan Sutton, I990), I4-I5.

34 'The Strange Tale of the Three Golden Fishes', David Eakin \& Helmut Gerber (eds), In Minor Keys: The Uncollected Short Stories of George Moore (Syracuse, NY: Syracuse University Press, 1987), 215. The story dates from 1927. 
are mercilessly mocked. The narrative invites inspection of the costumed flunkies: 'look at that attorney and the court sword ... It would be just as logical to stick a quill pen behind the ear of a fat pig'; 'at this moment a figure in knee-breeches and flesh-coloured stockings was seen waving a wand at the far end of the room. He was the usher clearing the way for the Vice-regal procession'. Officials in the parade are ridiculed whether as 'doge in an opera bouffa' or as 'underlings who swarm about this mock court like flies about a choice pile of excrement'.

The entire ritual, embraced by many as tradition, is dismissed as 'a poor ghost of royalty'. ${ }^{35}$ Contemporary political connotations receive attention too and, in relation to patrimoine, none more pointedly than when Lord Kilcarney faces the nightmare dissolution of his inheritance as he views Dublin: the statue of O'Connell, 'the man who had begun the work'; the 'colonnades of the Bank of Ireland' which had protected him but would not continue to do so with 'a new power established'; and Trinity College, 'ancient seat of wisdom and learning would perish before the triumphant and avenging peasant'. ${ }^{36}$ Change is inexorable: one man's patrimoine will crumble or fade as other chronicles and monuments achieve hegemony, for periods however long or short.

As Moore rhapsodizes and romanticizes about the lakes, hills and woods of Mayo, and lauds nature, he paints poetically and in unspoken contrast to industrial and repressive society. It appears too that he hints at the idea of an indefinable longing for the home place being a core part of human heritage. Yet, in contrast to the evidence of Moore's lyricism, his alter ego Harding asked: 'do you not see that man's moral temperament leads him sooner or later back to his connatural home? And we must not confuse home with the place of our birth. ${ }^{37}$ Still, Harding's tone is that of the brash young man about town, willing to argue a case, to advance a theory that he might espouse and reject with equal speed. When juxtaposed with depiction of the magic of the woods and water in The Lake, with the marked enjoyment of the participants in gossip and myth in A Storyteller's 
Holiday, with the dreamy pastoral setting for Daphnis and Chloe, Harding's proposition is less than totally convincing. On balance, if ever there was an author whose affinity with, and appreciation for, the physical and mythical qualities of his birthplace, it is George Moore. Numerous scenes and stories bear witness to that undeniable heimat. He may find homes in Paris, London, and Dublin but Mayo woods, lakes and tales are forever in the marrow of his bones. Heimat literature has always been laced with myth, ${ }^{38}$ and Moore never rejects legend and lore out of hand. He was more than willing to go with AE on a search for druids and fairies in Dowth, Tara and Newgrange - and that must be read as a demonstration that myth and legend and storytelling are an important embedded part of dúchas rather than that their content should be empirically verified or verifiable.

Moore's enthusiasms for French writers and painters - amongst them, Balzac, Flaubert, Zola, Manet, Pissarro, Degas, Cézanne - confirm the opinion that he interprets culture as enriched by contact and interaction across genres and on a wide geographical scale, and even back in time to Greece and Rome and the lands of the Blue Nile. On that global map, Moore never fails to engage with an important element of culture, the variety of religions and religious beliefs found in different places. His interest in the local, whether mores, myth or musical development further expands the scope of what may be included in dúchas. The outline concept may be both broad and eternal, but Moore holds that its individual interpretations are likely to be ephemeral. Patrimoine is a hybrid, an amalgamation between what is long-established and what is more recently imposed/installed (for whatever reason); its elements are very likely to be contested. For George Moore, regardless of the predictable antagonistic reception accorded to a dissenting author, dúchas and patrimoine are, and should always be, in flux.

38 See Elizabeth Boa \& Rachel Palfreyman, Heimat: A German Dream (Oxford: Oxford University Press, 2000), in particular 'Mapping the Terrain', I-29. 



\section{I2 'I don't think I could have made a decent living without the French': An Analysis of Reviews of Irish Literature in Le Monde, 1950-2017}

'I don't think I could have made a decent living without the French': this dramatic statement comes from acclaimed Dublin-born writer, Colum McCann. 'I was very lucky in France from very early on, more than twenty years ago', he continues. 'They adopted me after This Side of Brightness, which was a New York novel, but also it was written by someone who was European, so it somehow bridged the gap'. 'To date, McCann has been published in no fewer than thirty five languages; he has garnered to himself a veritable harvest of literary awards including the National Book Award, the Pushcart Prize, the Rooney Prize, the Irish Novel of the Year award, the Ireland Fund of Princess Grace of Monaco Memorial Literary Award, the Deauville Festival Literary Prize, the International IMPAC Dublin prize and a Guggenheim fellowship. He is a Chevalier des Arts et Lettres and holds several honorary degrees. The thought that such an illustrious career might never have taken off had it not been for French support at its outset, when McCann was still in his late twenties is, to put it mildly, arresting and even perturbing. Similar gratitude for French help in her career is acknowledged by Nuala O'Faolain. This is how O'Faolain's French publisher, Sabine Wespieser, recalls their first meeting:

I Colum McCann, The Irish Times, I February 20I5. Unless otherwise stated, all quotations from newspapers in this chapter are taken from Le Monde. Each quotation is followed by the day, month and year on which it originally appeared, as to dedicate a separate footnote to each quotation would be unwieldy. 
En 2002, j'accueillais Nuala O'Faolain à l'aéroport, son livre venait de sortir et la maison [Editions Sabine Wespieser] de se créer. Elle m'a sauté au cou en larmes, en me disant: 'C'est le plus beau jour de ma vie, je rêvais d'être éditée en France'.

[In 2002, I went to welcome Nuala O'Faolain at the airport. Her book had just been published, and Editions Sabine Wespieser had just been established. She hugged me and through her tears said: 'This is the best day of my life. I had always dreamt of being published in France'.]

If, for O'Faolain, this was 'le plus beau jour de ma vie', it was equally significant for Wespieser herself: in her entire career as a publisher, Wespieser hails this as nothing less than her 'plus beau moment'. Such strong declarations of support and of enthusiasm are perhaps unexpected. In fact, further investigation shows them to be merely the tip of an iceberg. In order to fully appreciate these assertions in the context of Franco-Irish relationships, this chapter will analyse the reviews of the key component of Irish patrimoine that is Irish literature that were published in what is arguably France's most prestigious and influential daily newspaper, Le Monde, over an almost seven-decade span from 1950 to 2017.

Avid readers of Le Monde's weekly Supplément Livres must be struck by its focus on works in translation. This frequency is hardly surprising in a country in which 40 per cent of the novels published annually are translations into French. ${ }^{3}$ To date, of the books reviewed in Le Monde over the

Sabine Wespieser, Le Figaro, 30 June 2008.

3 The role played here by the French state agency, the CNL (le Centre National du Livre), is significant and, indeed, inspiring. In 2016, for instance, its budget of c. 30 million euro provided support for 2,232 writers, translators, publishers and libraries as well as around 3,000 free literary events. The mission-driven nature of its activities is articulated by CNL President, Vincent Monadé: 'La culture est un remède à la barbarie. Si elle échoue, ce n'est pas parce qu'elle ne fonctionne pas, c'est parce que trop de gens encore en restent exclus, à la porte. Le CNL est là pour ouvrir la porte, donner à chacun la chance de devenir un lecteur et un citoyen à part entière. Avec le conseil d'administration, j'ai engagé le CNL pour faire de notre pays une nation de lecteurs' [Culture is a remedy for barbarism. If it fails, it is not because it does not function: it is because too many people are still excluded from it; they are outside the door. The $\mathrm{CNL}$ is there in order to open that door and give everyone the possibility of becoming 
decades under scrutiny, 374 are described as 'traduit de l'anglais (Irlande)'. Most appear in Le Monde's weekly Supplément Livres. Many benefit from not one, but two reviews, as they are reprised in the regular features, 'La liste de nos envies', 'Coups de coeur' and 'Livres en bref'. While these constitute the primary source material for this chapter, account will also be taken of a cornucopia of ancillary pieces such as reviews of TV documentaries on Irish writers, obituaries of Irish authors, translated opinion pieces by writers like Anne Enright (20 May 2010) and Joseph O’Connor (20 May 1999), a translation into French from German of an article on Seamus Heaney (is December 1990), pieces on the Abbey Theatre, on Michael D. Higgins, on censorship in Ireland and human interest-type pieces for M: Le Monde Magazine. To this must be added accounts of the showcasing in France of Irish literature through readings and literary festivals, and reviews of scholarly studies of Irish writers (I8 April 1997) with references to academic critics (including Bertrand Cardin, 6 July 2016). The Le Monde material also includes strong visual texts: numerous book covers, a Bloomsday drawing of a pensive Joyce by Aline Zalko (18 July I6), a haunting old black and white photo of Harcourt Street station to illustrate a review of Frank O'Connor ( 13 April 2017), photos inter alia of Edna O'Brien (more hauntingly beautiful as the decades roll by, 7 October 2008, 22 September 2016), of a brooding Colum McCann (6 July 2016), of a fetchingly dishevelled Karl Geary (12 October 2017) and of a wide-eyed Kate O’Riordan leaning against a kitchen fridge - a reminder of the aching ordinariness of her remarkable stories (7 April 2016). Such well-chosen material functions less as support than as co-construction of the reviews in question.

Some reviewers take us beyond the text, beyond the front door, into the writer's own personal space. They hint that they are offering us, the reader, something more than the workaday analyses on offer in the columns of other newspapers: one reviewer is at pains to point out that she was in Dublin in 2008 when Nuala O'Faolain died and can therefore report at first hand, from the front line as it were, on the deep impact that her death had at the time. Many indicate that not only did they read the book in question but

a reader and a complete citizen. With the board, I have mandated the CNL to make our country into a nation of readers], CNL: Rapport d'activités, 2016. 
that, undoubtedly helped by their Le Monde calling card, they also had the opportunity to meet the author - hence a series of interviews with Colum McCann in Paris and New York (Io October 2013), an interview with the normally reclusive William Trevor in London (19 April 20I2) and several interviews with Joseph O'Connor (I August 2003) including one in his Dublin bayside home (I7 August 200I). Fascinating up close and personal pieces on Beckett are provided by his friends, Philippe Sollers and American poet Anne Atik (13 November 2003). A frosty Edna O’Brien is interviewed in her Chelsea home by Florence Noiville, editor of foreign literature in $L e$ Monde: a veritable tour de force worth reading in its own right (7 May 2015).

Who are the reviewers? Over the years, la crème de la creme of Le Monde's reviewers are in action: Catherine Bédarida, Florence Noiville, Raphaelle Rérolle, Christine Rousseau, Josyanne Savigneau and Martine Silber. Reviews also appear from a host of leading writers: Michel Butor and Philippe Sollers on Joyce (5 February 1982, II June 2004), Hélène Cixous on Beckett (24 October 1969), Maylis de Kerangal ${ }^{4}$ on Frank O'Connor (13 April 2017) and Henri Bianciotti on Flann O’Brien (6 May 1995).

Who gets reviewed? This, surely, is one of the most interesting questions here. The Irish writer most mentioned in Le Monde over the decades is ... Oscar Wilde, referred to in I,IO4 articles to date. However, most of these allusions are fleeting ones - to Wilde's bons mots or to Wilde as icon. They are not sustained reviews of his work but crop up instead in articles on subjects as diverse as perfume, soccer and Belgian fashion. It is as if Wilde has become larger than the sum of his parts. There is even a reference to Emmanuel Macron quoting Wilde, evidence according to Le Monde's journalist, of the future president's sense of humour (28 August 2014)!

Next in the hit parade is James Joyce with 906 mentions. Here again, most are 'second-hand' references to James Joyce pubs, Leonard Cohen, Peggy Guggenheim, soccer, rugby, Apple and so forth. Similarly, of the 63 references to Frank McCourt, most are to the millionaire owner of OM (Olympique de Marseille), not to his Limerick namesake who penned Angela's Ashes.

4 For other Irish material in Kerangal's oeuvre, see her short story on the Lusitania sinking, in Ni fleurs ni couronnes (Paris: Verticales, 2006); see also Grace Neville, 'Occupied France offers literary response', Irish Examiner (5 May 2015). 
A wide spread of authors from north and south is included: mostly novelists, with a light sprinkling of poets and playwrights. Literature for children and young adults is included (29 April 2010) as are 'chick lit' (4 May 200I) and Irish detective novels (30 January 2015). An interesting case in point is how little poetry is reviewed and how little sustained analysis of the poetry of Nobel Prize winner, Seamus Heaney, is on offer. Le Monde mentions him 82 times in the decades under review, but most of these references are surprisingly fragmentary and fleeting, involving topics such as Heaney's political background, his family and his presence at various literary and cultural events. One of the all-too-rare sustained reviews of his poetry comes in the form of a piece translated from a German writer (is December 1990).

While a handful of writers from earlier times is included (Swift, Lawless, Sterne), there is an overwhelming preference for modern writers. Among these Edna O'Brien is the most frequently cited, but Nuala O'Faolain, Colm Tóibín and Roddy Doyle also feature strongly. Colm McCann is a particular favourite, with his novel, Zoli, warranting not one, but two lengthy reviews (23 April 2007 and 23 August 2007). Indeed, McCann emerges almost as 'one of us' for Le Monde: note, for instance, his interviewer's quiet satisfaction when, on meeting the writer 'dans son petit hôtel de Montparnasse, McCann évoque son attachement à Paris et à la France' [in his small hotel in Montparnasse, McCann evokes his attachment to Paris and to France] (6 July 2016).

One of the most interesting aspects of these reviews is their espousal of young and emerging Irish writers. There is high praise for first novels: Charlie le Simple [The Gamal] by Ciaran Collins (born 1977, Is October 2015), Jeunes Loups [Young Skins] by Colin Barrett (born 1982, 3 March 2016), Tout ce qui est solide se dissout dans l'air [All That is Solid Melts into Air] by Darragh McKeon (born 1979, 5 November 2015) and for Vera [Montpelier Parade] by Karl Geary (born 1972, I2 October 2017). Commendation of Hérésies Glorieuses [Glorious Heresies], the first novel of Lisa McInerney (born 198I), could hardly be stronger:

Drôle de sensation que d'assister à la naissance d'une romancière aussi chevronnée, aussi douée dès son premier livre que l'est Lisa McInerney, 35 ans. C'est comme etre 
témoin de la venue au monde d'Athéna, laquelle sortit tout armée de la tête de Zeus en poussant un cri de guerre. (I2 October 2017)

[What a strange feeling to be present at the birth of a novelist as seasoned and as gifted from her very first book as the 35-year old Lisa McInerney. It is like witnessing the arrival in this world of Athena who came fully armed and shouting a war cry straight out of Zeus's head.]

Equally significant, in the case of some newer writers, is the speed with which their work appears in French. The case of Karl Geary is illustrative here: a mere ten months after the publication of Montpelier Parade in January 2017, it appears in French translation (as Vera) to adulation from Le Monde (I2 October 2017).

Similarly intriguing is Le Monde's espousal of Irish-born authors not widely known in Ireland such as Gerard Donovan and especially Kate O'Riordan (who has six titles in the current Joelle Losfeld catalogue). Speaking in Lyon, O'Riordan disarmingly remarked that her novel, The Memory Stone (Pierres de Mémoire), sold very well in France but sold about ten copies in Ireland! In passing, it is perhaps salutary to read that in the late 1990 s the best known Irish poet, according to Le Monde, was not Seamus Heaney but John Montague, or that in 2009 Sebastian Barry was less famous in France than Dermot Bolger or Joseph O'Connor (24 September 2009).

Some of the Irish novels reviewed are set in France. These include Kate O'Riordan's Le Garçon dans la lune [The Boy in the Moon], which tells the story of an Irish woman living in Paris (28 May 2009). However, in other works tagged as 'traduit de l'anglais (Irlande)', Franco-Irish connections are more tenuous: Eoin MacNamee's novel, oo:23 Pont de l'Alma [ ${ }_{2.23}$ Paris 3 Ist August 1997] focuses on Diana's death in Paris; Colum McCann's Et que le vaste monde poursuive sa folle course [Let the Great World Spin] recounts the story of tight-rope walker, Philippe Petit. Some texts reviewed have nothing at all to do with Ireland or, indeed, with France. These include Darragh McKeon's fictionalized account of the Chernobyl disaster; Tout ce qui est solide se dissout dans l'air [All That is Solid Melts into Air]. Nonetheless, they earn their moniker, 'traduit de l'anglais (Irlande)', thanks to the birth place of their authors. On the 
other hand, despite its setting on the west coast of 'l'Irlande profonde', a point strengthened by a photo of a tumbledown cottage in a misty landscape that accompanies the review, Claire-Louise Bennett's L'Etang [Pond] is simply 'traduit de l'anglais', presumably because its author is English-born (4 January 2018).

This begs a question: who, among these authors, is Irish and who is not? This conundrum goes back at least as far as MacMorris's question in Henry $V$ : 'what ish my nation?'s Le Monde cannot be expected to crack it on its own. Identity slippage threatens: Kate O'Riordan is hailed as 'cette Irlandaise de Londres' (I9 July 2002). Colum McCann is 'irlandais', 'irlando-américain' (6 July 2016) and 'Irlandais, New Yorkais d'adoption' (4 February 2000). Indeed, his Seasons of the Night [Saisons de la Nuit] is his 'beau roman américain' (30 August 200I). Joseph O'Neill, born in Cork in 1964 to a Cork father and a Turkish-Syrian mother, is 'traduit de l'anglais (Etats-Unis)'. Limerick-born authors Michael Collins and Frank McCourt are both 'traduit de l'anglais (Etats-Unis)' (s March 1999, 3 May 200I).

Nor is that all: Edna O'Brien's accent sounds British (27 March 2013); 'le Henry Moore de la prose britannique' [the Henry Moore of British prose] (I9 April 20I2), Cork-born William Trevor has a 'sourire de vieux Britannique civilisé' [a smile of an elderly, cultured British person] (I4 June 200I); an anthology of Irish short stories is à déguster avec crumble et tasse de thé' [to be savoured over crumble and tea] (4 July 2003): surely not! On the other hand, one of the most perceptive articles here on shifting Irish identities concerns Boston-born author, Dennis Lehane. Lehane's father left Ireland in the 1940s 'avec le seul espoir de retourner chez lui' [with just one hope: to go home]. Years later, when his father retired, Lehane offered to take him back to Ireland.

Il m'a regardé comme un con: 'Qu'est-ce que tu veux que j'aille foutre là-bas, fils?' m'a-t-il demandé. Et il avait raison. Boston était devenu son antre. (M: Le Magazine du Monde, 17 January 2017)

5 See Eugene O’Brien, 'What ish my nation? Towards a Negative Definition of Identity', Minerva (vol. 2: 1998). 
[He looked as me as if I were an idiot: 'What would you want me to feckin' do back there?' he asked me. And he was right. Boston had become his burrow.]

His father was now an American.

Franco-Irish links are stressed throughout these reviews: the endless help that Joyce extracted from the French (I8 July 2016); the importance for Beckett of his French years (30 December 2015); the fact that Behan wrote The Borstal Boy in the Hôtel La Louisiane in Paris; the reminder that Liam O'Flaherty fought and was seriously wounded in France, hence the ensuing depression that permeates his writing, for instance his 1929 novel, Le Retour de la Brute [The Return of the Brute] (9 November 1984); the fact that Irish-American author J. P. Donleavy's classic, Gingerbread Man, was first published in Paris, in 1955, at Maurice Girodias' Olympia Press, as obscenity laws in Ireland and the US would have prevented its publication.

We are constantly reminded of Franco-Irish literary crossfertilization, for instance of the influence on Joyce of Flaubert and Maupassant (2I July 2005). We read that Behan, Claudel and Camus were friends (23 January 1987), as were Brian Colley, Jacques Maritain and Paul Claudel (19 July 1996). We learn of Máirtín Ó Cadhain’s predilection for Flaubert, both writers fascinated by 'des coeurs simples aux prises avec une angoisse soudaine qui leur révèle la complexité de leur destin' [simple hearts struggling with a sudden anguish that reveals the complexity of their destiny to them] (II December 1970). We discover that, more recently, inspiration flowed from an Oscar Wilde short story to Amélie Nothomb's Crime du Comte Neville (7 October 2005). However, of all these Franco-Irish cross references the most poignant is surely Nuala O'Faolain's shorthand description of her tragic mother as another Madame Bovary (I6 January 2003).

How does Ireland emerge from these articles? More than anything else as a country 'où la culture imprègne tous les aspects de la vie' [where culture infuses all aspects of life] (24 May 1996). Culture - especially literature constitutes the very core of our patrimoine, the essence of our identity, it is in our DNA. To quote Joseph O'Connor: 'En Grande-Bretagne écrire est une activité exotique. Ici [en Irlande], elle est centrale' [In Britain, writing is an exotic activity. Here [in Ireland], it is central] ( 16 March 1996). Our 
writers are, by far, the best of us, our best ambassadors. Commentators outdo each other to stress just how much Ireland is 'la terre bénie des écrivains' [the blessed land of writers] (17 April 2014), 'la terre de prédeliction des poètes' [the favourite land of poets] (19 July 1996), 'terre de rébellion par les mots' [the land of rebellion through words] (6 November 2013). Statistics, for instance the disproportionately high number of Irish winners of the Nobel Prize for literature, are corralled to strengthen this case: 'Peu de pays aussi petits que l'Irlande (3,8 millions d'habitants) ont donné naissance à tant de grands écrivains' [Few countries as small as Ireland, with its 3.8 million inhabitants, have given birth to so many great writers] (4 July 2003). Dublin is less a compilation of bricks and mortar than of words: 'Dublin est une cité faite de mots, dont l'emblème pourrait être un livre ouvert et dont l'une des devises ordonne, paraît-il, tu boiras et tu liras' [Dublin is a city made of words, whose emblem could be an open book, with a motto that seems to command: you will drink and you will read] (I7 August 200I). It is hardly surprising, therefore, that - arguably more than in Ireland - Michael D. Higgins is hailed here as a poet-president, the subject of resonant headlines such as: 'Michael Higgins, un poète à la tête de la République d'Irlande' [Michael Higgins, a poet to head up the Republic of Ireland] (29 October 201I) and 'Visite historique du président-poète irlandais à Londres' [Historic visit to London of the Irish poet-president] (8 April 2014).

Language, but specifically orality, reigns supreme here. Award-winning author, Maylis de Kerangal, captures this in her review of Frank O'Connor's Hôtes de la nation [Guests of the Nation]: 'irlandaises, ces nouvelles le sont plus encore par leur capacité à instaurer des voix [...] De fait, O’Connor écrit à l'oreille et ça s'entend' [these short stories are all the more Irish in that they are able to incorporate voices [...] Indeed, O'Connor writes from what he hears, which is something that can then be heard] ( 13 April 2017). In fact, unlike Moliere's Monsieur Jourdain ${ }^{6}$ who discovers that he had been speaking prose all his life without realizing it, Irish prose writers - at least according to many of these Le Monde reviews - are so lyrical that they sometimes cross 
over into poetry unbeknown to themselves, making them defacto poets: Edna O'Brien writes 'dans une prose poétique d'une grande beauté' [in a poetic prose of great beauty] (4 November 2010), Gerard Donovan has a 'style poétique' [a poetic style] (26 March 2009), Colum McCann's style is often 'quasi lyrique' [almost lyrical] (4 February 2000). OfCiaran Collins' novel, Charlie le Simple [The Gamal] we read: 'ce n'est pas le moindre paradoxe de ce texte brut et truculent, de devenir, en se dépassant lui-même, une manière de poème' [it is not the least paradox in this rough, truculent text that it goes beyond itself to become a kind of poem] (Is October 2015).

A keen awareness of Ireland as a land not of language but of languages is in evidence, with regular references to the Irish language, and to writers and publications in Irish. We are even treated to a valiant attempt at phonetic depictions of Irish pronunciation: Sean O'Faolain becomes 'Cwone O’Fweloine' (6 December 199I). Collective works (such as a bi-lingual anthology of Irish poetry, Anthologie de la poésie irlandaise du XXe siècle, under the direction of Jean-Yves Masson and with the collaboration of Pierre-Yves Lambert, is March 1996) and individual authors share the limelight: in a short piece by Catherine Bédarida, Nuala Ni Dhomhnaill is captured as poet, person and citizen, in all her richness, effervescence and free thinking ( 16 February 1996). Even writers not normally associated with the Irish language are enrolled under its banner. There is an explanation of the nickname of the main protagonist in Ciaran Collins' novel, The Gamal: 'au village, on le surnomme Gamal, soit attardé ou idiot en vieil irlandais' [in the village, he is given the nickname, Gamal, in other words the term for retard or idiot in Old Irish] (Is October 2015). Similarly, Colum McCann is quoted explaining how his writing, albeit in English, is infused with Irish rhythms: 'écrit en anglais sur un instrument de musique gaélique' [written in English over an Irish music instrument] (7 July 2016). A detailed essay on Flann O'Brien by Académie Française member, Hector Bianciotti, stresses his identity as a writer of Irish and English, before concluding with this powerful summation:

Joyce [...] a avoué, à propos de la langue anglaise, qu'elle serait toujours pour lui une langue acquise ; et Flann O'Brien, qui, dans le sillage de Joyce, jongle en virtuose avec l'anglais, doit la richesse de ses images et de ses inventions au gaélique. (6 May 1995) 
[Regarding the English language, Joyce [...] admitted that it would always be for him an acquired language; and Flann O'Brien who, in Joyce's wake, jungles with English like a virtuoso, owes the richness of his images and his inventions to Irish.]

The wider linguistic and societal ecosystem around these works is evoked. An illuminating and lengthy obituary of Máirtín Ó Cadhain by professor of Celtic languages and literature at the Ecole Pratique des Hautes Etudes, Paris, Pierre-Yves Lambert, touches on a sensitive issue: O Cadhain's refusal to allow his work to be translated into English as, for him, this would have constituted a form of betrayal (i December 1970). Elsewhere, the infamous Maamtrasna murder trial recalled in one of the short stories in Petits Romans noirs irlandais [Great Irish Detective Stories] and which caught the eye of the Le Monde reviewer is exactly the kind of illuminating story mined by Annales historians such as Eugen Weber in his unforgettable masterpiece, Peasants into Frenchmen: The Modernization of Rural France, $1870-1914:^{7}$

La Pendaison de Myles Joyce raconte l'histoire d'un homme de 70 ans [...] condamné à mort parce qu'il ne s'exprimait qu'en gaélique et que l'interprète qu'on lui avait affecté ne se donna pas la peine de traduire devant le tribunal des protestations embrouillées autrement que par des syllabes. (8 July 2004)

[The Hanging of Myles Joyce tells the story of a 70-year old man [...] condemned to death because he was able to express himself only in Irish and because the interpreter who had been assigned to him could not be bothered to translate for the court the man's confused protests other than by syllables.]

Is there a French way and an Irish way of reading these texts? Some thoughts on this vast question: the frequent references in these reviews to the Irish sky, with its constant flitting from blue to grey, emerge as some kind of metaphor for the perceived endless swooping between moods in the Irish psyche. Similarly striking are the recurrent allusions to the large

7 Eugen Weber, Peasants into Frenchmen: The Modernization of Rural France, I870-19I4 (Stanford, CA: Stanford University Press: 1976). See also Lorna Siggins, 'A wrongful hanging in Connemara, 1882', The Irish Times (2 May 2016); Seán Ó Curreáin, Éagóir (Dublin: Cois Life, 2016). 
families from which many writers come: we learn inter alia that Colm Tóibín was one of five children and that Nuala O'Faolain's mother was pregnant thirteen times. Are these hints at something larger (poverty, Catholicism ...)? Details like the colour of the sky and or family size would not normally be highlighted by Irish reviewers as points of interest or as instances of synecdoche, indications of something larger. (The sky is the sky, and family size is what it is). But one might suspect that the French reviewers here are sometimes less interested in literature than in cultural studies ('civilisation') and see literature as a doorway into a depiction of Ireland, its history and sociology, past and present. One might even occasionally wonder if, behind characters and plot, what they are really looking for is Ireland itself: 'Fille martyre de la guerre civile, l'Irlande est omniprésente dans le roman de Joseph O'Connor' [The martyred daughter of the civil war, Ireland is omnipresent in Joseph O'Connor's novel] (A l'Irlandaise / The Salesman, i2 February 1999). A reviewer would surely never remark of a French novel or of a French writer that they are 'la France tout entière'. Yet for many French reviewers here, individual Irish texts and writers somehow encapsulate the entire country all on their own, whether they ever intended to or not. Thus, we learn that Cré na Cille, Inishowen and The Hidden Testament offer miniature versions of Ireland, that Behan is 'l'Irlande tout entière' [Ireland in its entirety] (23 January 1987), that 'bien entendu, en se racontant elle-même, Nuala O'Faolain en dit beaucoup sur l'Irlande' [of course in telling us about herself, Nuala O'Faolain tells us a lot about Ireland] (I6 January 2003), that 'la sublime' Edna O'Brien 'dresse le portrait de l'Irlande' [draws up the portrait of Ireland], and that her Saints et pécheurs [Saints and Sinners] is nothing less than the 'autoportrait en miroir de l'Irlande' [a mirror image of Ireland's self-portrait] (I6 February 20I2).

Reviewers' assiduousness in mining Irish literary texts for depictions of three temps forts in recent Irish history is significant in this context:

I. the Ireland of the 1950s or more specifically 'l'Irlande de l'après-guerre, pays très pauvre dont les habitants sont soumis à un catholicisme forcené' [post-War Ireland, a very poor country whose inhabitants were 
quelled into a fanatic form of Catholicism], to quote from a review of a Benjamin Black / John Banville novel, 7 January 20ı。;

2. Celtic Tiger Ireland;

3. the post-Celtic Tiger collapse.

These three categories often overlap. Though some novels are clearly set in contemporary Ireland, nothing has moved on from the 1950s, at least if Le Monde's reviewers are to be believed. Donal Ryan's Une Année dans la vie de Johnsey Cunnliffe [The Thing about December] takes place in 'un coin paumé de l'Union européenne aujourd'hui' [a god-forsaken corner of the EU today] (I2 January 2017). Surely not! Although Edna O'Brien's 2015 novel Les Petites chaises rouges [The Little Red Chairs] focuses on a contemporary Bosnian war criminal living in Co. Clare among a mixed Irish-born and New Irish immigrant population, Le Monde deems it to be set in 'un trou perdu [...] un pays catholique très conservateur' [a backwater [...] a very conservative Catholic country] - again, surely not! Of one of the characters in this novel the reviewer states 'chaque tableau d'elle est comme une station sur un chemin de croix' [every image of her is like one of the stations of the cross], a reference that many young Irish people would no longer understand. One wonders just how au fait some of these reviewers are with contemporary Ireland (22 September 2016).

In this context, the portrayal of Edna O'Brien is particularly instructive. She encapsulates all the attractions of Irish writers for the French market, if these Le Monde reviews are anything to go by. She emerges as the oneperson embodiment of the history and sociology of Ireland from the r950s onwards through a merging of O'Brien herself and of her characters with recent Irish history (the temps forts alluded to earlier): from the stranglehold of the Catholic church in the I950s, to her dual exile into London and into writing, and finally to the gradual transformation of Ireland and its opening out to the wider world. Such is Le Monde's adulation of O'Brien, arguably its favourite living Irish writer, that she is sometimes paid the ultimate compliment of being (almost) enlisted as an honorary French writer: 'cette belle romancière, surnommée jadis la Françoise Sagan irlandaise' [this beautiful novelist once referred to as the Irish Françoise Sagan] (13 September 1969, I5 March 1996). 
Who publishes these Irish writers in France? All the leading literary publishers, including Gallimard, Grasset, and Seuil, but many more besides: Rivages, Belfond, Flammarion, Calman-Lévy, Phébus, Robert Laffond, Denoel, Actes Sud, L'Olivier, Christian Bourgois, Les Belles Lettres, I0/18, Fayard, Plon and Verdier. Special mention here should be made of two remarkable women publishers, Sabine Wespieser who has seven titles by Edna O'Brien and nine by Nuala O'Faolain,, and Joelle Losfeld with her veritable pantheon of Irish writers including Sebastian Barry, Dermot Bolger, Elizabeth Bowen, Maeve Brennan, Ciaran Collins, Peter Cunningham, Anne Enright, Carlo Gebler, Neil Jordan, Richard Kearney, Lisa McInerney, Sean O'Faolain, Liam O'Flaherty, Kate O'Riordan and William Trevor.

Ireland often looms larger in the French titles than in the original English ones: Irishness possesses a strong come-hither quality; it is clearly a brand that sells well:

Hugo Hamilton, The Sailor in the Wardrobe = Le Marin de Dublin [The Dublin Sailor]

Edna O'Brien, The Light of Evening = Crépuscule Irlandais [Irish Twilight] Flann O'Brien, At Swim Two Birds = La Kermesse Irlandaise [The Irish Hooley] Joseph O'Connor, The Salesman = A l'Irlandaise [In the Irish Manner] Nuala O'Faolain, Are You Somebody? = Les Mémoires accidentels d'une ferme de Dublin [The Accidental Memoirs of a Dublin Woman]

Pete McCarthy, McCarthy's Bar = L'Irlande dans un Verre [Ireland in a Glass]

That the insertion of Ireland or of Dublin into these French titles is no accident is confirmed by reviewers Raphaelle Rérolle and Martine Silber:

Traduit littéralement, le titre du roman de Joseph O'Connor aurait donné Le Représentant de commerce, ce qui ne fait évidemment pas une enseigne bien enivrante. En choisissant A l'Irlandaise, l'éditeur a sans doute opté pour un frontispice plus séduisant, qui attire l'attention du lecteur sur un pays dont la littérature est en vogue et l'histoire un point sensible de l'imaginaire européen. (I2 February 1999)

8 O'Faolain is reported to have left Wespieser 70 per cent of her literary estate (see Irish Independent, 22 February 2009). 
Les éditeurs sont sans doute extrêmement sensibles à ce poinçon irlandais, car ils n'hésitent pas à introduire le mot Irlande dans les titres français de façon à ce que le lecteur potentiel ne s'y trompe pas. (29 May 1998)

[Translated literally, the title of Joseph O'Connor's novel would have been the less than exhilarating Représentant de commerce [Sales Representative]. By going for $A$ l'Irlandaise [In the Irish Manner], the publisher has clearly opted for a more attractive cover which would focus the reader's attention on a country whose literature is in vogue and whose history resonates within the European imagination.

The publishers are no doubt extremely aware of this Irish hallmark: they unhesitatingly introduce the word Ireland into the French titles so that the potential reader is left under no doubt.]

A win-win relationship binds these Irish writers to their French publishers. Alongside the gratitude to their French publishers expressed by authors like McCann and O'Faolain is, in the opposite direction, the acclaim earned by Irish writers for their French publishers. This includes the prestigious Prix Fémina Etranger won in $200 \mathrm{r}$ by Keith Ridgway for Mauvaise Pente [The Long Falling] (Phebus), in 2004 by Hugo Hamilton for Sang Impur [Speckled People] (Phebus) and in 2006 by Nuala O'Faolain for L'Histoire de Chicago May [The Story of Chicago May] (Sabine Wespieser). Similarly, McCann's publisher Joelle Losfeld must have been chuffed when, in 2010, he was made a Chevalier dans l'Ordre des Arts et Lettres.

How is a match made between individual Irish writers and their French publishers? The answer would appear to be both formally and informally. A whole network of French literary matchmakers links publishers and foreign literary agents. Then there is the impact of book fairs (we are told that Eoin Colfer's agent is mobbed at Frankfurt), of literary events like the Etonnants Voyageurs festival, of Dublin's reign as European Capital of Culture in I991 and, overwhelmingly, of l'Imaginaire irlandais in 1996 which brought about a veritable step change in French awareness of the arts in Ireland. The descent of its 'bataillon' [battalion] (7 June 1996) of 600 invited writers and artists on over 100 French towns and cities was facilitated by a Franco-Irish budget of 20 million francs. Hence the arresting headline: 'L'Irlande exporte sa révolution culturelle en France' [ Ireland is exporting its cultural revolution into France] (I6 March 1996). 
More interesting, however, is what happens under the radar. Sabine Wespieser recounts how Edna O'Brien was prompted by a friend of Nuala O'Faolain to consider moving to Wespieser. At the time, O'Brien was being published by Fayard, but she jumped ship and a year later was being published by Wespieser (22 May 2013). The most illuminating explanation here comes from Joelle Losfeld herself (27 August 2009): 'je marche à l'intuition. Simplement, j'essaie d'établir une complémentarité entre roman français et roman étranger' [I operate through intuition. I simply try to establish some complementarity between French and foreign novels]. 'Ça marche au feeling', to use an anglicism!

The reviewers tend to be very earnest and informative regarding writers' careers and wider background: they do their homework. Extensive information is provided for instance about William Trevor's career (I9 April 20I2) and the impact of Joyce's wider family, especially his father and brother, Stanislaus, on his work (12 July 2012). Texts are read in detail and buttressed with footnotes. Lengthy extracts are provided in translation but also occasionally in the English original. One can forgive some stumbles: Franck O’Connor (13 April 2017)? Norma Barnacle (17 April 2013)? One of the most assiduous reviews is Philippe Sollers' analysis of a new translation of Ulysses, complete with copious lexical details (io June 2004). Florence Noiville's insightful review of William Trevor's work is a sheer delight (19 April 2012).

Again and again, one is struck by Le Monde's almost blanket praise for Irish literature:

Kate O'Riordan s'est imposée comme une redoutable entomologiste des passions humaines. Elle a transformé sa plume en une aiguille acérée, sensible aux moindres battements de cœur, frémissements de peau, murmures ou tremblements de voix. Pour mieux débusquer secrets, mensonges, faux-semblants, malentendus, silences et autres non-dits. (28 May 2009)

[Kate O'Riordan has established herself as a formidable entomologist of human passions. She has transformed her pen into a sharp needle that picks up the faintest beats of the heart, quivers of the skin, murmurs or tremors of the voice, all the better to unearth secrets, lies, deception, misunderstandings, silences and other kinds of reticence.] 
Keith Ridgway's short story collection En Temps Normal [Standard Time] earns similar adulation:

Terrifiantes parfois, inquiétantes souvent, angoissantes presque toujours en ce qu'elles révèlent les forces obscures qui nous gouvernent, ces nouvelles, ourlées d'ironie grinçante, montrent, s'il en était encore besoin, que Ridgway n'est pas seulement un romancier plein de finesse et d'inventivité, mais également un nouvelliste des plus redoutables. (26 May 2005)

[Sometimes terrifying, often worrying, almost always anguishing in that they reveal the hidden forces that govern us, these short stories, shot through with grim irony, show - as if such were still needed - that Ridgway is not just a novelist rich in subtlety and inventiveness, but also a most formidable short story writer.]

Reviews for other Irish books can be equally ecstatic. If they are to be believed, most if not all Irish literature is exceptional, 'étourdissant' [stunning] ( 5 November 2015). To reprise the old statistics joke: everything is above average! Young and old, these writers remind the French reviewers of everyone from Chekhov to Carver and Joyce. The young Colin Barrett recalls Carver and Joyce (3 March 2016); Dermot Bolger is like Faulkner and is a 'digne successeur de Joyce' [worthy successor of Joyce] (2 April 2015). A more dispassionate reader might be less than enthusiastic about some of the books reviewed. Not infrequently, a novel deemed 'passionnant' [riveting] (II September 2008) can be hard going. Beaumarchais' dictum comes to mind: 'sans la liberté de blâmer, il n'est pas d'éloge flatteur' [without the freedom to criticise, there is no praise that can flatter]. Man Booker prize winner and former Laureate for Irish Fiction, Anne Enright, seems to have similar misgivings:

O'Faolain's The Story of Chicago May sold 25,000 copies in France. At a guess, the story of an Irish emigrant prostitute in the United States in the 1890 s played better in French than in the original, either in Ireland or the US. ${ }^{9}$

Enright is being kind. Only rarely is a less than enthusiastic note sounded. The strongest criticism comes in a fleeting comment not from a French 
but from an Irish writer, Roddy Doyle: he dares to slam Ulysses as 'trop long, surfait et froid' [too long, overdone and cold] (13 February 2004). He may just have been playful!

The reviews shine a light on the translators themselves, those essential but much neglected 'créateurs de l'ombre' [creatures of the shadows] (22 May 2013) and on their potential for good or bad. As Raphaelle Leyris pithily remarks: 'mal écrire, c'est embêtant, mais mal traduire, c'est criminel' [to write badly is annoying; to translate badly is criminal] (22 May 2013). The translators are mostly women. Most are mentioned just once. Most leave behind hardly any imprint, digital or otherwise. A minority get several mentions: these include Michèle Albaret-Maatsch, Bruno Boudard, Carine Chichereau, Marie-Hélène Dumas, Philippe Gerval, Anna Gibon, Jean Guilloineau, Katia Holmes, Jean-François Menard, Jacqueline Odin, Florence Lévy-Paolini, Marie-Claude Peugeot, Jean-Luc Piningre and Edith Soonckindt. Some books require more than one translator: two for Joseph O'Connor's Inishowen ( 7 June 200I), Dermot Bolger's Toute la famille sur la jetée du Paradis [The Family on Paradise Pier] (29 May 2008) and Edna O'Brien's Les Petites chaises rouges [The Little Red Chairs] and three for Joseph O'Connor's L'Etoile des mers [Star of the Sea] (I August 2003). Writers occasionally translate other writers: Hervé Jaouen translates Liam O'Flaherty's L'Assassin (6 July 1996). In 200I, Sabine Wespieser herself, along with Julia Schmidt, translated Sheila O'Flanagan's Histoire de Maggie ( 4 May 200I). Some 'passeurs' are well known in their own right: one of Edna O'Brien's translators, Pierre-Emmanuel Dauzat, warrants a fascinating and highly informative profile by Le Monde journalist, Thomas Wieder (2I February 2008).

The constant praise for the texts under review does not always extend to their translations. While Pierre-Emmanuel Dauzat's translation of Edna O'Brien 'rend magnifiquement ce mélange de lyrisme et d'énergie brutale qui sont le marque d'Edna O'Brien' [conveys magnificently that mixture of lyricism and brutal energy that are Edna O'Brien's hallmark] (16 February 2012), and while Colm Tóibín's Brooklyn is 'remarquablement traduit' [remarkably translated] by Anna Gilson (3 February 20II), other translations are found wanting: the translation of Colum McCann's Ailleurs, ce pays [Everything in this country must] is 'souvent imprécise et 
lourde parfois aux limite [sic] du compréhensible' [often vague and heavy occasionally to the verge of incomprehension] (30 August 200I). That said, the titles chosen for French translations are often more informative than the English originals: the elliptical The Thing about December becomes Une Année dans la vie de Johnsey Cunnliffe; William Trevor's Love and Summer becomes Cet Eté-là [That Summer]; Colin Barrett's Young Skins becomes Jeunes Loups [Young Wolves]. Many of the French titles are, in fact, considerably cleverer than the original English ones:
Dermot Bolger, Tanglewood = Ensemble Séparés [Together Separated]
Nuala O'Faolain, Are you somebody? = On s'est déjà vu quelque part? [Have We Already Met Somewhere?]
Nuala O'Faolain, My Dream of You = Chimères [Chimeras]
Nuala O'Faolain, Almost There $=J$ 'y suis Presque [I'm Almost There]
Carlo Gebler, The Cure = L'Exorcisme [The Exorcism]
Hugo Hamilton, Surrogate City = Berlin sous la Baltique [Berlin under the Baltic]
Hugo Hamilton, Disguise $=$ Comme Personne $[$ Like No One]
Hugo Hamilton, Speckled People = Sang Impur [Impure Blood]

The French title, Sang Impur, is particularly inspired as it surely deliberately echoes problematic lines from the Marseillaise, thus hinting at considerations around race and 'purity' that haunt Hamilton's stunning, award-winning 2003 memoir. ${ }^{10}$

According to a recent article in L'Express on 'Les Secrets du Marketing Littéraire', ${ }^{11}$ the production of a bestseller nowadays requires an intense, well-staffed multi-media campaign with deep pockets; 25,000 to 30,000 euro per week would fund metro advertisements; another 20,000 to 30,000 euro per week would cover radio publicity spots. To that could be added the cost of desirable extras including extensive book tours or 6 metre high colour posters in the windows of bookshops like the FNAC on the rue de Rennes, Paris. The books reviewed in Le Monde clearly belong to another universe. A review in Le Monde may not have the immediate impact of a traffic-stopping six metre high poster in the FNAC windows on the rue

Io My thanks to Dr Loic Guyon for his discussion with me of this point.

II L'Express, 26 April 2017. 
de Rennes; nonetheless, Le Monde emerges from the above study as a force to be reckoned with in its de facto role as one of the main conduits into the wider Francophone world, over the past seven decades, of the key, age-old component of Ireland's patrimoine that is Irish literature. Its constant, generous and positive showcasing from the 1950s down to this day of this essential constituent of Irish patrimoine is surely thus deserving of far greater recognition.

Do Chlíona Ní Ríordáin: hommage, amitié. 


\section{Notes on Contributors}

EÓIN FlanNeRY is Senior Lecturer and Acting Head of the Department of English Language and Literature at Mary Immaculate College, University of Limerick. He is the author of four books: Ireland and Ecocriticism: Literature, History, and Environmental Justice (2016); Colum McCann and the Aesthetics of Redemption (2011); Ireland and Postcolonial Studies: Theory, Discourse, Utopia (2009); and Versions of Ireland: Empire, Modernity and Resistance in Irish Culture (2006). His edited publications include Enemies of Empire: New Perspectives on Literature, History and Imperialism (2007); Ireland in Focus: Film, Photography and Popular Culture (2009), and This Side of Brightness: Essays on the Fiction of Colum McCann (2012). His next book is provisionally entitled Debt, Affect and Literary Forms in post-Celtic Tiger Ireland.

Julien Guillaumond is a lecturer in English at Clermont-Auvergne University. He has a $\mathrm{PhD}$ from the Sorbonne on social and economic inequalities in twentieth-century Ireland. $\mathrm{He}$ is a member of the research groups Communications and Societies and Beverage Research Network. His research interests also include citizenship and inequalities in contemporary societies as well as various aspects of Irish political, economic and social history. He has published various articles and book chapters on aspects of his research.

TONY KIELY is a lecturer and researcher in the College of Arts and Tourism, TU Dublin, lecturing in the areas of business finance, marketing, strategic management and heritage tourism. His research interests incorporate the relationships between traditional music and tourism, church tourism and pilgrimage, festival tourism and identity, and their related social histories. He has presented at a range of international conferences. His most recent publications include, "From Tullycross to La Rochelle": Festival Food, French Connections, and Relational Tourism Potential', in Frank Healy 
and Brigitte Bastiat (eds), Voyages Between France and Ireland (Oxford, Peter Lang), “'Why Rita”: Devotional Practice and Pilgrimage Intent Towards a Medieval Italian Saint in Central Dublin', International Journal of Religious Tourism and Pilgrimage, 4/2, "We Managed": Reflections on the Culinary Practices of Dublin's Working Class Poor in the 1950s' in E. Maher \& M. Mac Con Iomaire (eds), 'Tickling the Palate': Gastronomy in Irish Literature and Culture (Oxford, Peter Lang), 'Resurrecting Harry Clarke; Breathing Life into Stained Glass Tourism in Ireland', International Journal of Religious Tourism and Pilgrimage, 2/2, 'Tapping into Mammon; Stakeholder Perspectives on Developing Church Tourism in Dublin's Liberties', Tourism Review 68/2, and 'Competencies: A New Sector', Journal of European Industrial Training, 26/2-4.

EAmon Maher is Director of the National Centre for Franco-Irish Studies in TU Dublin - Tallaght Campus. He is general editor of two series with Peter Lang Oxford, 'Reimagining Ireland' and 'Studies in Franco-Irish Relations'. Recent publications include Tracing the Cultural Legacy of Irish Catholicism: From Galway to Cloyne and beyond (Manchester University Press, 2017), with Eugene O'Brien, and The Reimaging Ireland Reader: Examining our Past, Shaping Our Future (Peter Lang, 2018). He is currently working on a monograph dealing with representations of Catholicism in the twentieth-century Irish novel.

Catherine Maignant is Professor of Irish Studies at the University of Lille (France). She was President of the French Association of Irish studies (SOFEIR) and President of the European Federation of Associations and Centres of Irish Studies (EFACIS) for a number of years. After writing a $\mathrm{PhD}$ on early medieval Irish Christianity, she now specializes in contemporary Irish religious history.

Patricia Medcalf is Lecturer in Advertising and Marketing at TU Dublin. Previously she was Project Director with branding specialists The Identity Business, and Marketing Consultant with Siemens. In 2004, she published the textbook, Marketing Communications: An Irish Perspective. Her $\mathrm{PhD}$ thesis analysed five decades of Guinness advertising in Ireland and whether or not 
this helped initiate, or merely reflected, social and cultural change. Her most recent publications in this area include a chapter in Voyages between France and Ireland: Culture, Tourism and Sport (2017); and 'In search of Identity': an Exploration of the Relationship between Guinness's Advertising and Ireland's Social and Economic Evolution between 1959 and 1969' (2016), in a special issue of Irish Communication Review Is (I), 3.

BRIAN MURPHY lectures at TU Dublin in hospitality management, wine/ beverage studies and gastronomy. He has a particular interest in food studies research and is keen to explore the role that place and heritage can play in how food and beverage products are perceived. He has written a number of book chapters and articles to date on the relationship between place/ story, and how people engage with food and drink. He is currently working on a monograph that situates the many facets of 'place perception' in modern Ireland's gastronomic landscape.

Grace Neville is Emeritus Professor of French at University College Cork, where she was Vice-President for Teaching and Learning from 2008 to 20I2. She studied at UCC, l'Université de Lille and l'Université de Caen. Her research publications cover Franco-Irish relations from the medieval to the modern period, as well as women's writing and language issues. She is a member of various boards and committees in Paris, including at the Sorbonne, the ANR (Agence Nationale de la Recherche) and the CRI (Centre de Recherche Interdisciplinaire). She holds the Légion d'Honneur and the Palmes Académiques.

Eugene O'Brien is a senior lecturer, and Head of the Department of English Language and Literature in Mary Immaculate College, University of Limerick, Ireland. He is also the editor for the Oxford University Press Online Bibliography project in literary theory. He has directed thirty-two $\mathrm{PhD}$ theses on the areas of Irish Studies and Literary and Critical Theory. His recent publications include Seamus Heaney as Aesthetic Thinker: A Study of the Prose (Syracuse University Press, 2016); The Soul Exceeds its Circumstances: The Later Poetry of Seamus Heaney (University of Notre Dame Press, 2016); Representations of Loss in Irish Literature, with Deirdre 
Flynn (Palgrave Macmillan, 20I8); Tracing the Cultural Legacy of Irish Catholicism: From Galway to Cloyne, and Beyond, 2nd edition, with Eamon Maher (Manchester University Press, 2018).

Maguy Pernot-Deschamps is a retired lecturer. She taught English in secondary education for twenty years before being appointed as a lecturer at the University of Burgundy, where she taught translation, Irish Studies and phonology. Her PhD thesis, defended in 1992, was on Neil Jordan's fiction and films. A book on Jordan's written work came out in 2009. She remains involved in Irish Studies, especially through AFIS, and is a regular visitor to the Centre culturel irlandais in Paris.

Mary PIERSE taught diverse literature courses at the School of English at University College, Cork, and has given courses on Irish feminisms for the MA programme in Women's Studies. Editor and compiler of the five-volume Irish Feminisms 1810-1930 (2010), she instigated the George Moore international conference series and has edited and co-edited several volumes on Moore's works. She also published on the writings of Kate Chopin, Antonio Fogazzaro, Katherine Cecil Thurston and contemporary Irish poets. Her ongoing research focuses on Moore's oeuvre, Franco-Irish artistic connections, and Irish women writers in the fin-de-siècle period. She is a board member at National Centre for Franco-Irish Studies.

DÉBORAH VANDEWOUde is a senior lecturer in English at the Université du Littoral Côte d'Opale where she lectures in British History, Irish Studies and Education. She holds a $\mathrm{PhD}$ on the Roman Catholic Church in contemporary Ireland. Her research interests include Irish Catholicism, popular religion, new religious movements, and religious education. She published L'Eglise catholique face aux défis contemporains en République d'Irlande (Peter Lang) in 20I2. She has also published a series of articles on the response of the Catholic Church to secularization and on the communication strategies designed by the institution. Her recent contributions include 'Whitefriar Street Church: An Institutional Perimeter for an Unframed, Polymorphic Religious Practice' in New Critical Perspectives on Franco-Irish Relations, ed. Anne Goarzin (2015), 'L'Eglise catholique irlandaise, creuset d'intégration 
des Travellers', in Irlande: Identité et Interculturalité, eds Bairbre Ní Chiosáin and Charlotte Rault (2015) and 'Renouveau catéchétique en Irlande: processus d'intellectualisation de la foi', in Croyances contemporaines: regards croisés sur le monde anglophone, ed. Fréderic Armao (2017).

Harry White is Professor of Music at UCD and a Fellow of the Royal Irish Academy of Music. He is founding general editor of the 'Irish musical studies' series (with Gerard Gillen), and was inaugural President of the Society for Musicology in Ireland. His publications include Music and the Irish Literary Imagination (2008), Musicologie sans Frontieres (2010; edited with Ivano Cavallini), Musical Theatre as High Culture? (2011; edited with Vjera Katalinič and Stanislav Tuksar), Polite Forms (2012), The Encyclopaedia of Music in Ireland (2013; edited with Barra Boydell), A Musical Offering. Essays in Honour of Gerard Gillen (2017; edited with Kerry Houston) and The Kenmare Occurrences (2018). His The Musical Discourse of Servitude is forthcoming in 2019. He was elected to the Royal Irish Academy in 2006, to the Academia Europaea in 2015 and to the Croatian Academy of Sciences and Arts in 2018. 



\section{Index}

I9I6, I8, 2I-22, 24, 27-3I, 60, 62, 64, 7I, $87,220,226,231$

$2016,3,9,18,28-30,36,51,60,62,71,75$, $87,89,96,105-107,121-2,124$, I26-8, I30, I3I-6, I65, I85, I88, $238,247,257,259$

advertising, 8, I43, I45, I50, I54-5, I60, I86, I91, 192, 195, I99

alcohol, 97, 143-4, I54, I89

Algeria, 6, 205-10, 214, 216-I8

American culture, 154

Arabic, 210-II, 217

artisan, 83, 87, I00, I65, I70, I83

Atwood, Margaret, 7, 35

authenticity, 8, 31, 106-7, I18, I22, I37, I64-5, I67-8, I70, I72, I74-5, $177,179,182-6,196,219,224$, 226, 228

autobiography, 207-8, 210-II, 213, 216, $2 \mathrm{I} 8$

Ballagh, Robert, I49, I54

Balzac, Honoré de, 3, 235

Barry, Gerald, 59, 72-4, 242, 250

Barry, Sebastian, 59, 72-4, 242, 250

Battle of the Boyne, 84, 86, 88, 100

Bax, Arnold, 72

BBC, I48, I55, I58, 232

Bealtaine, III, II 4

Begag, Azouz, 9, 207-17

Bell, Desmond, 67, 86, $158-9$

Beranger, Gabriel, 90-2

Bhabha, Homi, 32

Big House, 50, 52-3 bishop, II 4

Bolger, Mary Ann, I86, 190-I, 242, 250, $253-5$

Book of Kells, 130

Bord Bainne, I87, 19I-3, I95, 201

Bordeaux, 3, 89

Bourdieu, Pierre, 6, I4-8, 20, 22-3, 25-8, I 80

Boydell, Brian, 64, 66-7, 262

brand identity, 160

Brexit, 2, 14, 230

Britain, 72, 83, 89, I28, I30, I48, I87,

$$
\begin{aligned}
& \text { I9I-2, I94-5, 205-6, 209-IO, } \\
& 224,230-I, 244
\end{aligned}
$$

British, iv, 5, I4, 21, 27-30, 60, 72-4, 93, II7, I48-50, I58, I86, I90-I, I94, 206-7, 216-7, 224, 232, 243, 26I

Bulson, Roy, $145-6$

butchery, xiii, 8, I63-4, I68-77, 179-84

butter, 9, 185-95, 197-9, 201-2

Calvinism, 84

Camus, Albert, 6, 244

Carole Saturno, 206-7, 218

Carson, Ciaran, 68

Catholic Church, I, 6, 29, 63-6, 72, 8I-4, $88-9,94,98-100,123,126,132$, I34-40, I 44, 2II-I2, 249, 26 I

Celtic, 2, 6, 35, 37-9, 4I, 48, 50-I, 62, 65-6, 73, III-I2, II4-I5, II7-I9, I29, I3I-2, 247, 249, 257

Ceoltóirí Chualann, 70

Channel 4, 158

Chieftains, The, 70-I, I49-5I

China, 87, I27 
Christ, II3, 126

Christian, 29, I09, II3, II5, II7, I23-4, I27-9, I3I, I35-9, 227, 229, 250, 258

Church, 7, 26, 72, I08, I09, III, I24, I3I, I33-40, 258, 26I

Clonmel, 85, I68, I70-I, I75-6, I79, I87 commemorations, I8, 20-I, 24, 27-8, 8 I communications, I5I, I57-6I

Connolly, Frank, I43, I 47 consumer, I25, I55, I76, I79, I9I-2, 202 consumerism, I22, I55

Cork Butter Market, 187 credit, 7, 39, 45-9, 53 Croagh Patrick, I3I, 135 Cronin, Michael, 55, 106 cuisine, 186 cultural ambassador, $168,176-7$ cultural heritage, xiii, I, 5-6, 8, I3-I4, I7-I $8,20,33,35,88,118, I_{23}$, I29-3I, I37-8, I43, I46, I56, $164,166,174,177,182,186,207$, 209-I $4,217,228$

cultural identity, 36, I58, 165

culture, xiii, I-IO, I3-I8, 20-I, 25, 30, 3I, 33, 33-9, 4I, 49, 59, 60-9, 70-6, $88,90,100,104,116,118,121-139$, I43-6I, I64-8, I73-4, I76-8, I82, I83, I84, I86, I88, I90, I92, 201, 206-17, 219-20, 222, 225-30, 235, 238, 24I, 244, 248, 25I, 259

dairy, I85, I88-95, I99, 201 Dargan, William, 96-7, IоI Deane, Seamus, 58, 6I-3 debt, xiii, 7, 35-6, 39, 40-55, 229 decodification, 168,179 deconstruction, 6, 27, 33 Demossier, Marion, 164, 166 Derrida, Jacques, I 4, 19-20, 22, 27, 33 Dervan, Michael, 60
Dienst, Richard, 4I

Donn, son of Mil, II2-I4 doxa, 6, I4-5, I8, 20-3, 26-7, 29-30, 32-3 dream, 44, 62, 118, 215-17 drink, 144, I46, I54, I66, I70, 174, I76, $178-9,182-4,188,198,213,245,259$

Du Noyer, George Victor, 90-3, 96 Dublin, xiii, 3, I8, 22, 27, 49, 57, 60-9, $75-7,8 \mathrm{I}-2,85-96,99-100$,
I08, I12-I3, I16-I7, I28, I3I, I36,
I45-6, I49, I54-9, I65, I68-9,
I7I, I83, I87-8, I9I-2, 206, 220,
$234-5,237,239,240,245,247$,
$250-1,25-8,259$

dúchas, 6, I3-4, I8, 219-33, 235

Durcan, Paul, I49, I54

Easter Rising, 18, 21, 24, 27, 52 economic, I, 6, 7, 9, I6, 35-4I, 45-9, 5I-5, $67,96,97,104-5,119,121,125$, 130, I39, I44, I54, 156, 166-7, I77, $183-4,205,224,230,233,257$

economic crash, 46

Elliott, Robin, 75, 77

emigration, 8-9, 67, 99, I44, I49-50, I57, 160, 208, 210, 215-18, 253

Encyclopaedia of Music in Ireland, The, $64,67-8,74-6,262$

England, I-2, 5, 9, 27, 43, 82, 84-5, III, I44, I49, I53, I94-5, 205-6, 2II, 216, 230-I

English, xiii, xv, I3-I4, 25, 54, 6I-3, 66, $72-3,86-7,116,151,165,173-4$, I98, 207, 216-I7, 221, 230, 232, $243,246-7,250,252,255,257$, 259, $26 \mathrm{I}$

Enright, Anne, 239, 250, 253

Europe, 7, 14, 20, 36, 37, 52, 59, 62, 64-8, $76,82-3,88-9,94-5,99$, I04, II3, II5, I22, I28, I30, I5O, I58, I73, I78, I89-90, 193-4, 20I 
European Economic Community, I56, 193

European modernism, 74

evangelization, $\mathrm{I} 23$, I35, I37-9

exile, 74, I57, 214-I5, 249

Fáilte Ireland, 106-7, 116, I18, 129-30

faith, 8, 54, II5, I23, I26, I29-3I, I33-40, 211, 229-30

faith-based tourism, I2I, I2 4

Fanon, Franz, 5

field, $6,15-18,20-3,27-8,30,32-3,60$, 92, 93, 107, 195

Field Day Anthology of Irish Writing, The, 58

Fleischmann, Aloys, 67, 72

food, $97,133,144,164-6,168,170,174$, 176, I78-9, I82-5, I87-8, I9I, 213-I4, 259

Foucault, Michel, 40, 46-8, I25

Fourth Space, xi, 164-70, 172, 174, 179, I $82-4$

France, i, iii, vii, viii, xiii, xiv, $x v, I-3$, 5-I4, 35-6, 75, 77, 8I-8, 90-I, 97, I0O, I09, II 4, II 6, I2I-8, I37-40, $164-6,173,178,180,185-6$, I88,I90, I98, 205-2II, 2I5-I8, 22I, 223-30, 23I, 235-2, 244, 247-53, 255, 257-9

Franco-Irish, xiii, 57, 238, 242, 244, 25I, 258-9, 26I

Gandon, James, 94-5

gastronomic heritage, $\mathrm{I}_{3}$

gastronomy, I, 9, $163-7,172,176-8,182$, I84, I86, 259

Georgian Period, 60-I, 93-4

Germany, viii, 8, 9, 37, 57-9, 69, 82, 84, 93, 173, 185-6, 188-90, 193-202, 229, 23I, 235, 239, 24I global, 8, 37-9, 4I, 46, 49, 69, II8, I5I, I 84,235

Graeber, David, 4I

Grattan Flood, W.H., 64-5

Great Famine, 91, 96, 99

Greece, 25, 225-6, 235

green, 97, I51, 154, 188-9, 192, 195-6, 198, 200-I

Groupement Européen d'Intérêt Economique, 187

Guinness, viii, I, 8, 89, 94-5, 98, I30, I $43-57,160-I, 176,258,259$

habitus, $6,15-18,21-8,30,32-3$

Hamilton, Hugo, 250-I, 255

Heaney, Seamus, 3, 33, 59, 77, 209, 212, 239, 24I-2, 259

Heidegger, Martin, 25, 26

Henebry, Richard, 64

heritage, xiii, I, 2, 6-9, I4, 35-39, 4I-2, 55, $60,62,65,70,74-8,81,82,86,89$, 93, 95, 99, 100-10, II5-19, I22-30, I3I-40, I43-6, I5I-2, I57, I60, 161, I64-71, 176-7, I82, 185-6, 192, $196,202,210-14,217-29$, $232-4,257,259$

Hewson, Paul, I48-9, I54, I6I

Higgins, Michael D., 239, 245

historical imagination, 219

history, 5-6, 8, I3-I4, 20-I, 23, 32, 35-9, $40-1,44-7,50,52-4,59-68$, $70-6,8 \mathrm{I}-2,9 \mathrm{I}-2, \mathrm{IOO}, \mathrm{I03}, \mathrm{IO} 7$, I09, II4-I7, I25, I27, I29, I34, I38, I 47-8, I5O, I79, I84, I87-8, I92, 205, 219, 224-9, 232, 248-9, 251, 257-8

homogenisation, 159

Huguenots, vii, 7, 81, 83-7, 89, 94, 99-100 
identity, 5-6, 9, $14-15,32,36,43,47-8$, $66,69-70,75,77,8 \mathrm{I}-2,96,105$, II5-I6, I38, I40, I43-4, I46, I48-9, I55-6, I59-60, 166-7, 172, $175-6,190,200,216,220,224-6$, 229, 231, 243-6, 257

imagination, 3, 69, 103, 107-8, II9, I57, $217,219,251$

immigrants, 6, 86, 93, 100-I, 207, 21I, 215 immigration, 85, 154, 205-6, 209, 215, 217 inheritance, xiii, $6,7,13-15,18,22-3,36$,

$39,42,50,53,57,67,78,144$, $219-20,223,230,234$

integration, 53, $17 \mathrm{I}$

International Commission for the Study of Communication Problems, 157-9

internationalisation, $6,10,39,62,73-4$, $77,96, \mathrm{I} 2 \mathrm{I}-2, \mathrm{I} 24-7, \mathrm{I} 43, \mathrm{I} 46$, I 48-9, I50-2, I55-7, I60-I, I64, $176,224,257,261$

IRA, 2I, 24

Iraq, 224

Irish Dairy Board, I87, I89, I9I-2, 194-5, I99, $201-2$

Irish identity, 9, 20, 65, 66-7, II5, I44, I50, I56, I60, 17 I, 176, 190, 20I, 230

Irish literary canon, 58-9

Irish literature, 7, 10, 42, 59, 61, 78, 155, $238-9,252-3,256$

Irish pub, 75, 145

Irish Times, The, 71, 147, 171, 176, 178, I88-9, 194, 237, 253

Irish Tourism Board, 130

Irish traditional music, 64, 66, 68-70, 75,186

Irishness, 8, 72, 176, 210, 250

Jordan, Neil, I 49, I54, 202, 250, 259
Joyce, James, 3, 52-4, 57, 59, 63, 99, I46-7, $239-40,244,246-7,252-3$

Kalouaz, Ahmed, 9, 207-18

Keaney, Brian, 9, 207-10, 212-16

Kearney, Richard, I48-9, I54-9, I6I, 250

Kerrygold, xi, 8, 9, 185-6, 189-202

Kiberd, Declan, 2I, 3I, 38-9, 58, I55-6, I6I

Kilroy, Claire, 42, 48-55

Klein, Axel, 60, 62-3, 67

Knock shrine, $130-5$

La Rochelle, 82, 84-9, 257

La Touche Family, 88, 97-8, IOI

language, $2-3,9,3 \mathrm{I}-2,35,40,-\mathrm{I}, 66$, $82,90-1,116,137,180,210-11$, 213-14, 217, 220-4, 237, 246-7, 259

Latin, 13-I4, 35, 23I

Lazzarato, Maurizio, 44, 46-8, 52, 54

Le Monde, viii, xiii, 9-10, $128,237-43$, $245,247,249,252,254-6$

Leerssen, Joep, 222, 229-30

legend, I08-9, II3-14, 225-6, 235

Liberties, The, 86,88

literature, I, 5, 7, 9, 19, 24, 32, 38, 42, 44, $48-9,59,60-2,65-6,73-4,76$, $78,81,147,155,219-25,227,232$, 235-9, 240-I, 244-5, 247-8, 250-I, 259, 26I

Lloyd, David, 6I

London, 3, 4, 16, I7, 20-2, 24, 28-9, 31-2, $35,37,4 \mathrm{I}-2,49,6 \mathrm{I}-3,73,83$, 86-7, 94-5, II2, II5, I3O, I45, I48, I57, I66, I88, 207, 208-9, 212-I4, 220-I, 23I-2, 235, 240, 245, 249

Longley, Edna, 32-3

Lough Derg, II3, I3I-3

Lydon, John, 9, 207-16 
McCann, Colum, 237, 239-40, 242-3, $246,254,257$

McGahern, John, 3-5, 57

Magdalen Laundries, 32

Mahmud, Tayyab, 40

Management Plan 2008-2018, 104,109

marketing, 8, 40-I, 47, I05, I16, I22, I27-8, I3I, I39, I49, I64, I76-7, I8I, I85, 190-5, I98, 202, 249

Martyn, Edward, 65

Mary, viii, xv, 9, 57, 92, I26, I31, I34, I86, 2I8-I9, 22I, 225, 228, 257, 259, 26I

Mathews, Aidan, 7, 37-9, 57-8

media, 27, 29, 35, 4I, 58, I24, I28, I48, I54, I58, 198,255

media landscape, 158

Mediterranean, 205-6, 215

memory, 19-20, 22, 29, 36, 45-6, 48, 57,

$77,81,101,112,140,174,212,217$, 223,225

metanoia, $\mathrm{I5}, 25-8,33$

Middle Ages, IO3, IIO, II3, 224

migration, I, 87, IIO, I57, 205-6, $23 \mathrm{I}$

monastery, I08-II, II3, 223

monk, 29

Mont St Michel, II 4

Montreal Symphony Orchestra, 77

Moore, Christy, I43, I 47

Moore, George, viii, 2, 3, 9, 65, 219, 220-I, $225,232-3,235,26 \mathrm{I}$

morality, 44-6, 48, 55, 226

Moran, Ciarán, I52, I54-5, 160, 230

Morin, Jean-Pierre, 127

Murphy, Brenda, 146

Murphy, M.J., I63, I68, I69-7I, I75, I77, I79, I 82,183

music, xiii, $7,38,58-78$, I30, I43, I 48-5I, I55, I6I, I80, I86, 213-4, 219, 223 , $226-7,229,235,246,257,262$

myth, 64, 198, 225-6, 229, 234-5
Naipaul, V. S., $42-4$

nation, 2, I4, 2I, 28, 30, 32, 35, 38-9, 52, 63, $64,66,75,77,81,90,93,96,101$, I04-5, I15-16, I25, I35-6, I38-9, I43-6, I49, I54-5, I56, I58-60, I68, 193-5, 219-29, 231, 238, 243, 245

Neely, William, 8I, Io I

Nietzsche, Friedrich, 40, 44-7, 52, 54

North Africa, 213-I4

Ó Riada, Seán, 67-70

O'Brien, Carl, I46-7

O'Brien, Edna, 239-4I, 243, 246, 248,

249, 250, 252, 254

O'Connor, Frank, 239-40, 245

O'Connor, Joseph, 57, 59, 239-40, 242, 244, 248, 250-I, 254

O'Connor, Nuala, I48-9

O'Faolain, Nuala, 10, 237-9, 24I, 244, 248, 250-2, 255

Office of Public Works, 104, 107

O'Flaherty, Liam, 244, 250, 254

Oldenburg, Ray, I66, 172-4

orphanages, 98

Palladian style, 93

Panaïté, Oana, 5

patrimoine, xiii, I-4, 6, 9-II, I4, 23, 59, 8I, $83,86,90,99,103,108,116,125$, $138,164-6,170,172,174,176-7$, I8I, I83-4, I86, 202-3, 219-27, $234-5,238,244,256$

patrimony, 6-7, I3-I8, 20-I, 33, 57, 60, 62, $65,67,7 \mathrm{I}-8, \mathrm{I} 43, \mathrm{I} 48, \mathrm{I} 60$

Penal Laws, 2, 97-8

pilgrimage, 92, IIO-I3, I17, I22, I29, I3I-6, 257

politics, I4, I9, 2I-2, 24-5, 27, 30, 32, 35-6, 39-40, 44-8, 5I-2, 60-I, $73,76,81,88,158,219,227-8,232$, 234, 24I, 257 
Pope Francis, 136, I38

postmodernity, 17,26

propaganda, 220, 227, 230

protected designation of origin, 178

protected geographical indication, 178

Protestant, vii, 60, 62-4, 8I-6, 89-90,

$$
\text { 98-100, } 230
$$

publishing, xiii, 9, 17, 104, 238, 250, $25 \mathrm{I}$

Redmond, John, 6I

reflexive thinking, 22-26, 32

Reformation, 83, III

refugees, 83,97

religion, xiii, $13,32,4 \mathrm{I}, 62-3,67,76,8 \mathrm{I}-6$, $98,100,117,121-40,211-12,220$, $222,226,228-30,235,258,261$

religious tourism, I23, I28

Republic, I, 19, 37, 52, 67, 158-9, I86, 193, I99, 245

Republican, 2I, 33

Revolution, I, 9I-2

Ridgway, Keith, 251, 253

ritual, II2, I43, I46, 2I2, 234

Rocamadour, 125

roots, 35, II2, I35, I37, I52, I6I, I65, I98, 206

Rowley, Rosemarie, I55

Roy Foster, 37, 62

RTÉ, 67, 71, 77, 155, 158-9

Ryan, Donal, 249

sacred, 63, 103, I13, I19, 133-4, 136, 138

St Fionan, 108

St Michael, 103, I08, II3-I5, II7

St Patrick's Cathedral, 8I, 86-7

Schumann, Robert, 57

Selicato, Francesco, 35-6

Shaw, Bernard, 60, 62, 68, 73, II 8

Sinn Féin, 27, 38

Skellig Michael, xiii, 8, IO3-I3, II5-I8

Sollers, Philippe, 240, 252 spirituality, I09, II7, I2I, I24-I32, I35-8, I4O, 2I2-I3, 227

Stanford, Charles Villiers, I5, 17, 19, 20, $25,68,72-4,247$

Star Wars, 105, 106, 117-18

Stivers, Richard, I44

story, 4, 57, 82, 134, I54, I60, I68, I71, $178-9,184,207,221-2,225-8$, $235,239,243,245,247,253$

story of place, 168,175

Swift, Jonathan, 60, 86, 24I

Tech Duinn, II2

techmology, I57, 228

technology, 8, I50-I, I57-9, I66-7, I7I, I 83,228

terroir, 3, I64-8, 170, 177, I82, I84, 201

Third Place, I66, 172-4

tourism, xiii, $8,82,99$, IOI, I05-7, I2I-40, I56, I86, I91, I96, 200-I, 232, 257

tours, 77, 122-3, I27, I31, 134, 138, 255

tradition, xiii, 8-9, I5, I9, 3I, 38, 43, 63-7I, $75,78,108, \mathrm{IIO}-\mathrm{II}, \mathrm{II} 3, \mathrm{II} 5-\mathrm{I} 7, \mathrm{I2} 2$, I32, I46, I48, I55-6, I63-4, I66, 168, 170-88, 198-9, 202, 213-14, $219,223,227,232-4,257$

Trevor, William, 240, 243, 250, 252, 255 Tyrrell, Peter, 28-29, 32-3

UNESCO, xiii, 8, 103-4, 107-8, II5-16, II 8, I25, I 86

USA, 2, 59, 94, 99, I26, I49, I55, I73, I87, 230-2

Vatican, I24, 136-7, 139

Viking, 82, 109

visual imagery, I43-4, 228-30, 232, 239

Wespieser, Sabine, 9, 237-8, 250, 25I-2, 254 
Whelan, James, 29, 84-5, 168-77, 179, I $8 \mathrm{I}-4$

Wilde, Oscar, 60, 74, 91, 110, 240, 244 William of Orange, 84, 88, 93

World Heritage Site, 8, 103-5, I09
Yeats, W. B., 3, 21, 24-5, 26, 31, 57-63, $65-6,72$

Zola, Émile, 3, 235 



\section{STUDIES IN FRANCO-IRISH RELATIONS}

\section{Series Editor:}

Dr Eamon Maher, Technological University Dublin

The aim of this series is to foreground areas of interdisciplinary and multidisciplinary connection between France and Ireland, as well as stressing the European dimension of the Franco-Irish nexus. The series also provides a forum for French-language scholarship within the field of Irish studies.

We welcome proposals from a variety of disciplinary backgrounds, including historical, cultural, literary, sociological, political and linguistic perspectives. The series publishes books in both English and French and all submissions will be peer-reviewed.

Proposals should be sent to eamon.maher@ittdublin.ie or ireland@peterlang.com.

L'objectif de cette collection est de valoriser les recherches multidisciplinaires ou inter-disciplinaires relatives à la France et à l'Irlande, et de souligner la dimension européenne des relations franco-irlandaises. La collection offre également un espace d'échanges pour la recherche francophone en études irlandaises.

Nous accueillons des projets de publication relevant de différents champs disciplinaires et s'inscrivant dans une perspective historique, culturelle, littéraire, sociologique, politique ou linguistique. Les ouvrages de la collection sont publiés en anglais et en français ; tous les projets sont soumis à une évaluation par les pairs.

Les propositions peuvent être envoyées à eamon.maher@ittdublin.ie ou à ireland@peterlang.com. 
Vol. 1 Eamon Maher, Eugene O'Brien and Grace Neville (eds) Reinventing Ireland through a French Prism ISBN 978-3-631-56639-8. 2007

Vol. 2 Eamon Maher, Grace Neville and Eugene O'Brien (eds) Modernity and Postmodernity in a Franco-Irish Context ISBN 978-3-631-58158-2. 2008

Vol. 3 Yann Bévant, Eamon Maher, Grace Neville and Eugene O'Brien (eds) Issues of Globalisation and Secularisation in France and Ireland

ISBN 978-3-631-59052-2. 2009

Vol. 4 Déborah Vandewoude

L'Eglise catholique face aux défis contemporains en République d'Irlande. Rédefinition d'une institution désacralisée ISBN 978-3-631-61897-4. 2012

Vol. 5 Karine Deslandes

Regards français sur le conflit nord-irlandais ISBN 978-3-631-64593-2. 2013

Vol. 6 Chris Reynolds

Sous les pavés ... The Troubles: Northern Ireland, France and the European Collective Memory of 1968 ISBN 978-3-631-62643-6. 2014

Vol. 7 Edwige Nault

L'avortement en Irlande : 1983-2013. Dimensions religieuses, socioculturelles, politiques et européennes ISBN 978-3-631-65654-9. 2015 
Vol. 8 Janick Julienne

Un Irlandais à Paris. John Patrick Leonard, au cœur des relations franco-irlandaises (1814-1889)

ISBN 978-1-906165-67-3. 2016

Vol. 9 Frank Healy and Brigitte Bastiat (eds)

Voyages between France and Ireland. Culture, Tourism and Sport

ISBN 978-3-0343-2264-5. 2017

Vol. 10 Agnès Maillot, Jennifer Bruen and Jean-Philippe Imbert (eds) Non-Violent Resistance. Irreverence in Irish Culture ISBN 978-1-78707-707-2. 2018

Vol. 11 Agnès Maillot and Jennifer Bruen (eds)

Non-Violent Resistance. Counter-Discourse in Irish

Culture

ISBN 978-1-78707-711-9. 2018

Vol. 12 Cécile Maudet

L'autrefois et l'ailleurs: Poétique de la rupture dans I'oeuvre littéraire de Colum McCann

ISBN 978-1-78874-491-1. 2018

Vol. 13 Fabrice Mourlon

L'urgence de dire : L'Irlande du Nord après le conflit ISBN 978-1-78874-611-3. 2018

Vol. 14 Eamon Maher and Eugene O'Brien (eds)

Patrimoine/Cultural Heritage in France and Ireland ISBN 978-1-78874-660-1. 2019 
